UNIVERSIDADE DE SÃO PAULO

INSTITUTO DE QUÍMICA

\title{
DESENVOLVIMENTO DE MÉTODOS E INSTRUMENTAÇÃO PARA AMOSTRAGEM E DETERMINAÇÃ̃O DE ALGUMAS ESPÉCIES RELACIONADAS AOS PROCESSOS DE ACIDIFICAÇÃO DA ATMOSFERA
}

FLAVIO ROBERTO ROCHA

TESE DE DOUTORADO

Prof. Dr. IVANO GEBHARDT ROLF GUTZ

ORIENTADOR

SÃo PAULO

2003 
Ficha Catalográfica

Elaborada pela Divisão de Biblioteca e

Documentação do Conjunto das Químicas da USP.

Rocha, Flavio Roberto

R672d Desenvolvimento de métodos e instrumentação para amostragem e determinação de algumas espécies relacionadas aos processos de acidificação da atmosfera / Flavio Roberto Rocha. -- São Paulo, 2003.

$220 \mathrm{p}$.

Tese (doutorado) - Instituto de Química da Universidade de São Paulo. Departamento de Química Fundamental.

Orientador: Gutz, Ivano Gebhardt Rolf

1. Química analítica : Métodos 2. Química ambiental I. T. II. Gutz, Ivano Gebhardt Rolf, orientador. 


\section{"Desenvolvimento de métodos e instrumentação}

para amostragem e determinação de algumas espécies relacionadas aos processos de acidificação da atmosfera"

\section{FLAVIO ROBERTO ROCHA}

Tese de Doutorado submetida ao Instituto de Química da Universidade de São Paulo como parte dos requisitos necessários à obtenção do grau de Doutor em Química - Área: Química Analítica.
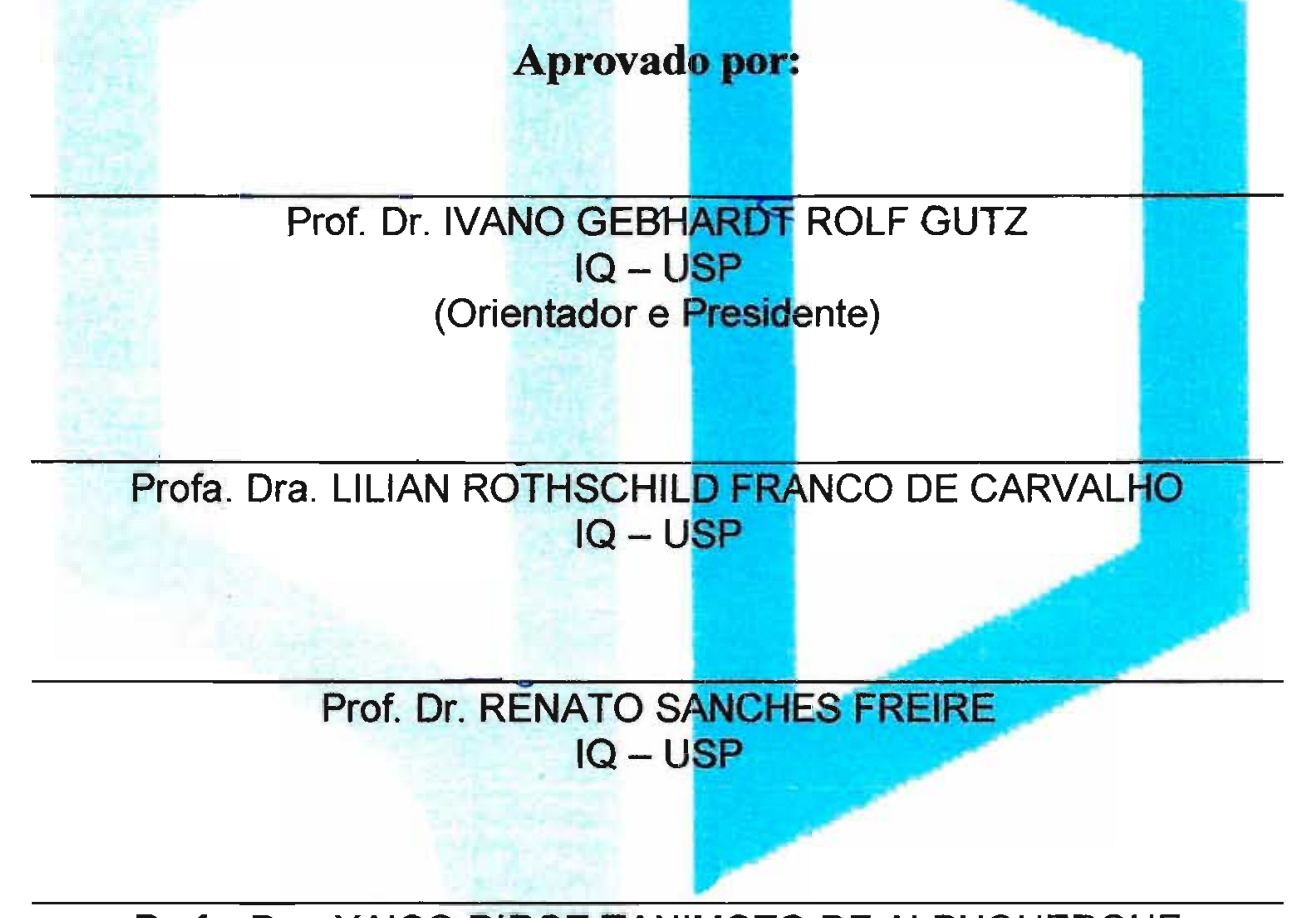

Profa. Dra. YAICO DIRCE TANIMOTO DE ALBUQUERQUE UFU

Profa. Dra. MARIA DE FÁTIMA ANDRADE
IAG - USP

SÃO PAULO

27 DE JUNHO 2003. 
Aos meus pais, Neide e Izahias, pela minha formação, pelo carinho, dedicação, incentivo e exemplo de vida, meu reconhecimento e eterna gratidão. 
Ao Prof. Dr. Ivano G.R. Gutz como exemplo de profissionalismo e competência, pela orientação amizade, incentivo e confiança durante esta valorosa jornada, o meu reconhecimento, minha gratidão e minha profunda admiração. 
À minha esposa Irlene, pelo carinho, pelo incentivo, pela compreensão $e$ principalmente pelo companheirismo e serenidade em nossas vidas. 


\section{Agradecimentos}

Ao meu sobrinho Márcio, minha irmã Mara, minha avó Maria (in memoriam), ao Sérgio, meus tios Zezo, Nancy, Tim e Izabel e toda minha familia, pelo carinho e incentivo.

Aos familiares José e Marlene, João e Suely, pelo carinho e amizade.

Ao Guilherme e Amarilis, pela amizade, pelo incentivo, pelo auxilio nos trabalhos, pelas valiosas discussões e pelos disputados campeonatos de xadrez.

Ao René e Cláudia, pela amizade, pelo incentivo, apoio, pelas caminhadas ecológicas e valiosas discussões. 
Ao Prof. Dr. Claudimir e Prof. Dr. Lúcio, pela amizade na realização deste trabalho.

Aos amigos do laboratório Adriana, Andréa, Alexandre, Carol, Daniela, Dosil, Eduardo, Osmar, Rodrigo, Sérgio, Heron, Socorro, Marlene, Carlos, pelo apoio, companheirismo e contribuições no desenvolvimento do trabalho.

Aos professores Dr. Mauro, Dra. Silvia e Dr. Jairo, pelo incentivo e aprendizado.

Ao amigo Dr. Alberto Fracassi, pelos trabalhos realizados em conjunto.

Ao Dr. José Geraldo e Dra. Adalgiza, pelos trabalhos realizados em conjunto nesta tese.

À Dra. Sueli Borrely do IPEN, pelos trabalhos realizados em parceria.

Ao Fabiano e ao Vítor, pela amizade e auxilio neste trabalho.

Aos técnicos Fernando e Ricardo, pela coloboração na realização das pesquisas.

À Lucia Helena, pela colaboração e realização dos trabalhos e amizade.

Ao Elias, Yuki e Paulo, pela amizade e apoio.

Ao pessoal da secretaria de pós-graduação, que de alguma forma contribuíram para a realização deste trabalho.

Ao $\mathrm{CNPq}$ pela bolsa concedida.

E a Deus, pelos caminhos trilhados... 


\section{ÍNDICE}

RESUMO.

ABSTRACT

CAPÍTULO I - INTRODUÇÃO.

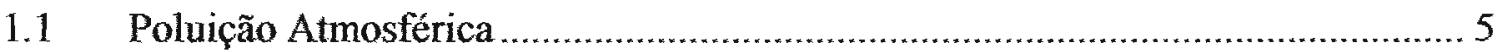

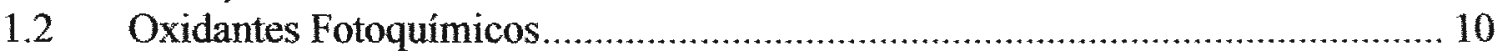

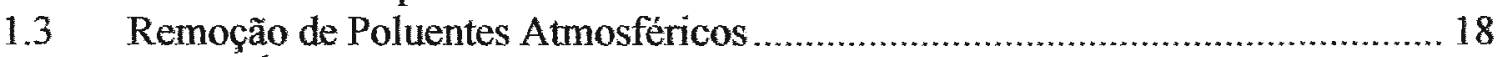

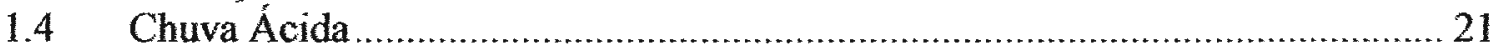

1.4.1 Histórico da Deposição Ácida ..................................................................... 27

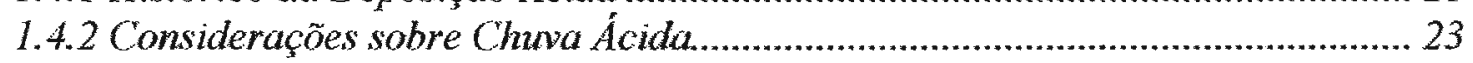

1.5 Poluição Atmosférica na Região Metropolitana de São Paulo ………………..... 28

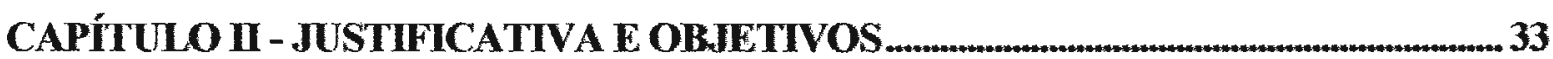

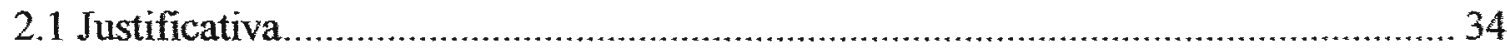

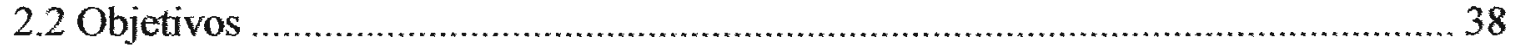

CAPÍTULO III-DESENVOLVIMENTO DE MÉTODOS PARA COLETA DE ESPÉCIES QUÍMICA DE RELEVÂNCIA AMBIENTAL NA FASE GASOSA DA ATMOSFERA.

3.1 Desenvolvimento de Coletor por Difusão através de Tubos Capilares Porosos de Polipropileno

3.2 Desenvolvimento de Crioamostrador para $\mathrm{H}_{2} \mathrm{O}_{2}$

CAPÍTULO IV - METODOLOGIAS DESENVOLVIDAS PARA DETERMINAÇÃO DE ESPÉCIES QUÚMICAS NA FASE GASOSA DA ATMOSFERA POR ELETROFORESE CAPILAR COM DETECTOR CONDUTOMÉTRICO SEM CONTATO

4.1 Metodologia Desenvolvida para Determinação de Formaldeído e Ácidos Fórmico e Acético por Eletroforese Capilar com Detector Condutométrico sem Contato

4.1.1 Considerações Gerais sobre Formaldeúdo....................................................... 49

4.1.2 Consideraçôes Gerais sobre os Ácidos Fórmico e Acético ................................ 58

4.1.3 Coleta de Formaldeído e Ácidos Fórmico e Acético na Fase Gasosa Utilizando-se Coletor por Difusäo com Tubos de Polipropileno.

4.1.4 Determinçâo de Formaldeído e Acidos Fórmico e Acético por Eletroforese Capilar com Deteção Condutométrica sem Contato na Fase Gasosa da Atmosfera.

4.1.5 Dispositivo para Formaçăo de Atmosfera Padrão de Formaldeido.................. 68

4.1.6 Resultados e Discussão ............................................................................... 71

4.2 Metodologia Desenvolvida para Determinação de Amônia por Eletroforese Capilar com Detector Condutométrico sem Contato ..................................................... 88

4.2.1 Considerações Gerais sobre Amönia ............................................................... 88

4.2.2 Coleta de Amônia na Fase Gasosa da Atmosfera Utilizando-se Coletor por Difusão de Polipropileno. 
4.2.3 Determinação de Amônia por Eletroforese Capilar com Detector Condutométrico sem Cotanto na Fase Crasosa da Atmosfera..................................... 94

4.2.4 Resultados e Discussão .................................................................................. 95

CAPÍTULO V - METODOLOGIA DESENVOLVIDA PARA DETERMUNAÇ̃̃o DE $\mathrm{H}_{2} \mathrm{O}_{2}$ NA FASE GASOSA DA ATMOSFERA POR INJEÇÃO EM FLUXO COM DETECÇ̃̃O AMPEROMÉTRICA EM ELETRODO DE GOTA PENDENTE DE MERCÚRIO 102

5.1 Considerações Gerais sobre Peróxido de Hidrogênio

5.2 Amostragem de Peróxido de Hidrogênio na Fase Gasosa da Atmosfera com

Coletor por Difusâo através de Tubo Microporoso e com Coletor Criogênico .

5.3 Determinação Polarográfica de $\mathrm{H}_{2} \mathrm{O}_{2}$

5.4 Dispositivo para Viabilizar Análise em Fluxo em Célula Eletroquímica

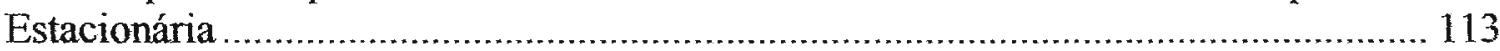

5.5 Desoxigenador para Sistema em Fluxo ...................................................... 116

5.6 Sistema Fia para Detecção de $\mathrm{H}_{2} \mathrm{O}_{2}$ na Fase Gasosa da Atmosfera Utilizando

Coletor por Difusão ................................................................................... 118

5.7 Uso da Catalase para Conferir Seletividade ao Sinal Amperométrico ................... 121

5.8 Resultados e Discussão ......................................................................... 123

CAṔ́tulo VI - AVALIAÇÃo da COMPOSIÇÃO IÔNICA DE ÁGUA DE CHUVA POR ELETROFORESE CAPILAR COM DETECCÃO CONDUTOMÉTRICA SEM CONTATO.

6.1 Aspectos Gerais

6.2 Local da Amostragem de Água de Chuva.

6.3 Amostragem de Água de Chuva.

6.4 Determinação de Íons em Água de Chuva por Eletroforese Capilar com

Detecção Condutométrica sem Contato ................................................................ 143

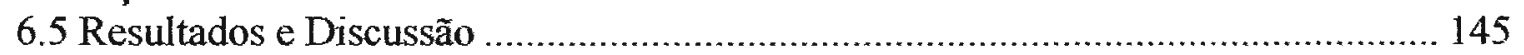

CAPÍtULO VII - APLICAÇÃO dAS METODOLOGIAS DESENVOLVIDAS A OUTRAS MATRIZES.

7.1 Determinação de Espécies de S(IV) em Amostras de Vinho por Injeção em Fluxo com Detecção Amperométrica em Gota Pendente de Mercúrio......................... 164

7.1.1 Considerações Gerais sobre Espécies de S(TV) em Amostras de Vinho .......... 165

7.1.2 Determinaçẫo Polarográfica de $\mathrm{HSO}_{3}^{-}$.................................................... 168

7.1.3 Determinação Amperométrica em Fluxo de $\mathrm{HSO}_{3}^{-}$Livre em Amostras de Vinho.

7.1.3.1 Utilização de Formaldeído para Garantir Seletividade ao Sinal Amperométrico.

7.1.4 Determinação Amperométrica em Fluxo de $\mathrm{HSO}_{3}^{-}$Total em Amostras de Vinho.

7.1.5 Determinação de $\mathrm{SO}_{2}$ em Amostras de Vinho em Fluxo................................. 178

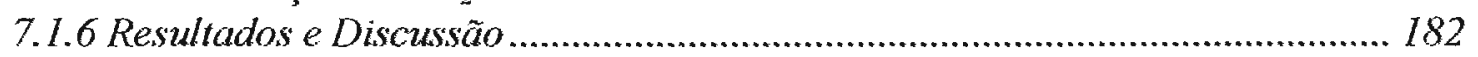

7.2 Determinação de $\mathrm{H}_{2} \mathrm{O}_{2}$ em Efluentes e Água de Cultivo de Daphnia Similis após Irradiação com Feixes de Elétrons

7.2.1 Determinação Amperométrica de $\mathrm{H}_{2} \mathrm{O}_{2}$ por Injeção em Fluxo em Efluentes

e Água de Cultivo de Daphnia Similis. 


\section{CAPÍTULO VII - CONCLUSÕES E PERSPECTIVAS}

8.1 Análise de $\mathrm{CH}_{2} \mathrm{O}$ e dos Ácidos Fórmico e Acético na Fase Gasosa Mediante Coleta por Difusão e Determinação Eletroforética

8.2 Determinação de $\mathrm{NH}_{3}$ na Fase Gasosa da Atmosfrea Mediante Coleta por Difusão e Determinação Eletroforética

8.3 Análise de $\mathrm{H}_{2} \mathrm{O}_{2}$ na Atmosfera através de Coleta por Difusão e Criogênica Seguida de Determinação Amperométrica em Fluxo

8.4 Determinação dos Íons Majoritários em Água de Chuva por Eletrofores Capilar.. 193 8.5 Determinação de Espécies de S(IV) por Amperometria em Fluxo em Amostras de Vinho

8.6 Determinação de $\mathrm{H}_{2} \mathrm{O}_{2}$ por Amperometria em Fluxo com em Efluentes e Água de Cultivo de Daphnia Similis após serem Irradiados com Feixes de Elétrons 


\section{RESUMO}

A atmosfera, ao lado dos principais gases que a compõe, apresenta em menores concentrações milhares de compostos químicos (orgânicos e inorgânicos) distribuídos nas fases líquidas e gasosa ou no material particulado. Quando esses compostos encontrados no ar apresentam níveis de concentração que os tornam impróprios ou nocivos à saúde humana, aos animais ou vegetais e danosos aos materiais, são considerados poluentes atmosféricos.

Neste trabalho, enfatizou-se o estabelecimento de métodos alternativos, eficientes e práticos, para a amostragem de várias espécies que participam dos processos de acidificação da atmosfera, assim como o desenvolvimento de métodos analíticos baseados em técnicas eletroanalíticas em fluxo como a amperometria e a eletroforese capilar com detecção condutométrica sem contato.

Devido a algumas limitações das técnicas de amostragem, explorou-se a alternativa de recorrer a tubos capilares com paredes microporosas, preenchidos com solução adequada à absorção das espécies em pauta, após sua difusão através dos poros da membrana hidrófoba. Assim, construiu-se um coletor por difusão utilizando-se tubo de Teflon $^{(\mathrm{s})}$, dentro do qual foi introduzido um feixe de tubos capilares porosos de polipropileno. A união desta técnica de amostragem com a determinação seletiva e quantitativa dos analitos por eletroforese capilar com detecção condutométrica (CE-CCD) possibilitou o desenvolvimento de métodos completos para as seguintes espécies: $\mathrm{CH}_{2} \mathrm{O}$ coletado em água deionizada, à frequêencia de 1 amostra por hora, seguido de derivatização com $\mathrm{HSO}_{3}{ }^{-}$para determinação de formaldeído na forma de hidroximetanossulfonato (HMS); $\mathrm{HCOOH}$ e $\mathrm{H}_{3} \mathrm{C}_{2} \mathrm{OOH}$ - com o mesmo procedimento de coleta e separação por CE$\mathrm{CCD}$ aplicado na determinação de $\mathrm{CH}_{2} \mathrm{O}$ na forma de $\mathrm{HMS}$; e $\mathrm{NH}_{3}$ - coletado em solução de $\mathrm{HCl}$ e determinado na forma de $\mathrm{NH}_{4}{ }^{+}$por $\mathrm{CE}-\mathrm{CCD}$.

Outra espécie de interesse ambiental é o $\mathrm{H}_{2} \mathrm{O}_{2}$, por participar de várias reações de oxidação tanto na fase gasosa como na fase liquida da atmosfera, contribuindo assim para a acidez da atmosfera. A determinação analítica do $\mathrm{H}_{2} \mathrm{O}_{2}$ foi feita por método FIA amperométrico com eletrodo de gota pendente de mercúrio, adaptando-se célula eletroquímica estacionária ao trabalho em fluxo. Duas formas de coleta de $\mathrm{H}_{2} \mathrm{O}_{2}$ na fase gasosa foram desenvolvidas e comparadas: 
- coleta por difusão - com fluxo de água deionizada pelos feixe de filamentos capilares; nesta aplicação, o feixe foi conectado diretamente à alça de amostragem do injetor, proporcionando determinações "on-line".

- amostragem criogênica em dispositivo "passivo" - aproveitando o fato conhecido de que a razão $\mathrm{H}_{2} \mathrm{O}: \mathrm{H}_{2} \mathrm{O}_{2}$ da fase gasosa se mantém praticamente inalterada na fase sólida (gelo coletado)

Além das determinações de $\mathrm{H}_{2} \mathrm{O}_{2}$ na fase gasosa, o método FIA-Amperométrico foi utilizado, em trabalhos realizados em parceria com pesquisadores do IPEN, para determinação dessa espécie em efluentes e ảgua de cultivo do microcrustáceo Daphnia similis após serem irradiados com feixes de elétrons.

Paralelamente às pesquisas relacionadas a espécies gasosas, desenvolveu-se metodologia para a determinação de cátions e ânions majoritários em água de chuva, recorrendo à $\mathrm{CE}-\mathrm{CCD}$, de modo a oferecer uma alternativa à consagrada técnica da cromatografia de íons, demorada e onerosa. Os estudos iniciais da composição iônica da chuva foram feitos com coletas de água de chuva efetuadas no período de Abril/97 a Março/98. Nesse conjunto de amostras determinou-se as concentrações dos cátions $\left(\mathrm{NH}_{4}^{+}\right.$, $\left.\mathrm{Ca}^{2+}, \mathrm{K}^{+} \mathrm{e} \mathrm{Na}^{+}\right)$e dos ânions $\left(\mathrm{NO}_{3}^{-}, \mathrm{SO}_{4}{ }^{2-} \mathrm{e} \mathrm{Cl}\right)$, além das usuais medições de $\mathrm{pH} \mathrm{e}$ condutividade. A Eletroforese Capilar mostrou-se particularmente favorável para a determinação dos íons majoritários em água de chưva.

Embora fugindo da área ambiental, desenvolveu-se metodologia para determinação de espécies de S(IV) em amostras de vinho, a partir de algumas adaptações de método amperométrico em fluxo desenvolvido no mestrado para análise de sulfito e HMS em água de chuva. Assim, desenvolveu-se três sistemas FIA-Amperométrico com eletrodo de gota pendente de mercúrio distintos, os quais foram utilizados para determinação de $\mathrm{HSO}_{3}{ }^{-}$livre e adutado (na forma de hidroxialcanossulfonatos) $\mathrm{SO}_{2}$, com auxílio de uma unidade de difusão gasosa. 


\section{ABSTRACT}

Alongside with its main components, the atmosphere contains trace amounts of thousands of chemical compounds (organic and inorganic) distributed in the liquid and gaseous phases, as well as in the particulate matter. These species can be considered pollutants when they are encountered at levels capable of generating adverse effects to humans, animals, plants or materials.

The aim of this work was to establish alternative, efficient and practical methods for the sampling of several species encountered in the gaseous phase, as well as to develop analytical methods based on electroanalytical flow techniques, such as amperometry and capillary electrophoresis with contactless conductometric detection (CE-CCD).

Due to some limitations in the existing sampling techniques, an alternative method based on the diffusion of the analytes through the microporous hydrophobic walls of capillary tube filled with an appropriate absorbent solution, was investigated. The collecting device was assembled using a Teflon tube wherein a bundle of porous capillary polypropylene tubes was introduced. The coupling of this sampling technique with the selective and quantitative determination of the species by capillary electrophoresis with contactless conductometric detection (CE-CCD) enabled the development of complete analytical protocols for the following species: i) $\mathrm{CH}_{2} \mathrm{O}$ - collected in deionized water at a frequency of 1 sample/h and derivatized with $\mathrm{HSO}_{3}{ }^{-}$for its determination as hydroxymethanesulfonate (HMS); ii) $\mathrm{HCOOH}$ and $\mathrm{H}_{3} \mathrm{COOH}$ - collected using the same sampling procedure and quantified upon separation by CE-CCD; and iii) $\mathrm{NH}_{3}$ - collected in a $\mathrm{HCl}$ solution and determined as $\mathrm{NH}_{4}{ }^{+}$form.

Another species of environmental interest is $\mathrm{H}_{2} \mathrm{O}_{2}$, which contributes to the acidity of the atmosphere on account of its involvement in some oxidation process both in the gaseous and liquid phases. The determination of the $\mathrm{H}_{2} \mathrm{O}_{2}$ was carried out using a FIA amperometric method at the hanging mercury drop electrode, in a batch electrochemical cell adapted to function under flowing conditions. Two sampling procedures for $\mathrm{H}_{2} \mathrm{O}_{2}$ in the gaseous phase were developed and compared:

- collection by diffusion - from the air into a flow of deionized water within the bundle of capillary filaments, which were, in turn, connected to the sample loop in order to allow on-line determinations. 
- cryogenic, with a "passive" sampler - based on the well-known fact that the $\mathrm{H}_{2} \mathrm{O}$ $: \mathrm{H}_{2} \mathrm{O}_{2}$ ratio in the gaseous phase is practically maintained in the solid phase.

In addition to these determinations in the gaseous phase and in a partnership with researchers of the IPEN, the FIA-Amperometric method was used for the quantification of $\mathrm{H}_{2} \mathrm{O}_{2}$ in effluent and in cultivation water of the microcrustacean Daphnia Similis after irradiation by $\mathrm{MeV}$ electron beams.

In parallel to the related research, a methodology for the CE-CCD determination of majority cations and anions in rain water was developed. This was proposed as an alternative method to well-established ion chromatography techniques. Initial studies on the ionic composition of rain were conducted on samples collected between April/97 and March $/ 98_{*}$ using an automatic collector previously developed. In this set of samples, the concentrations of cations $\left(\mathrm{NH}_{4}^{+}, \mathrm{Ca}^{2+}, \mathrm{K}^{+} \mathrm{e} \mathrm{Na}{ }^{+}\right)$and anions $\left(\mathrm{NO}_{3}^{-}, \mathrm{SO}_{4}^{2-} \mathrm{e} \mathrm{Cl}\right)$ were determined, together with the usual measurements of $\mathrm{pH}$ and conductivity. Capillary electrophoresis turned out to be particularly suitable for the determination of ions in rain water.

Although strictly not environmental in kind, a methodology for determination of S(IV) species in wine samples was implemented by adjusting a previously-developed flowamperometric method for the analysis of sulfite and HMS in rain water. For this purpose, three distinct FIA-Amperometric systems using a gas diffusion device and the hanging mercury drop electrode were designed, assembled and used for the determination of $\mathrm{HSO}_{3}{ }^{-}$ in the free and bound forms (as hydroxyalkanesulfonates) and $\mathrm{SO}_{2}$. 
CAPÍTULO I - INTRODUÇÃO 
A atmosfera é uma mistura de gases que envolvem o globo terrestre; com poucas dezenas de quilômetros de espessura, atua como uma camada de proteção da vida na Terra. Contém o oxigênio para a respiração e o gás carbônico para a fotossíntese, tem vital importância no ciclo hidrológico, filtra grande parte da radiação eletromagnética ultra-violeta, entre outras propriedades.

Aproximadamente, o ar seco é constituído de $78 \%$ (V/V) de nitrogênio, $21 \%$ de oxigênio, $0,9 \%$ de argônio, $0,03 \%$ de dióxido de carbono e outros gases traço abaixo de $0,002 \%$, tais como: gases nobres, metano, óxidos de nitrogênio, hidrogênio, dióxido de enxofre, ozônio, dióxido de nitrogênio, amônia, monóxido de carbono, aldeídos, peróxido de hidrogênio, radicais livres, freon e muitos outros. As principais fontes emissoras desses gasestraço incluem atividades antrópicas, emissões biogênicas e reações fotoquímicas. A umidade do ar pode variar entre 0,1 a $5 \%$ do volume da atmosfera.

Apresentando significativas variações de temperatura, a atmosfera divide-se em várias camadas. A camada da atmosfera que sofre maior influência da atividade humana é a troposfera, por ser nela que reside cerca de $90 \%$ de massa total de ar da atmosfera e onde ocorre a maior parte das transformações químicas de interesse ambiental, provocadas principalmente por reações fotoquímicas (Seinfeld, 1986).

A troposfera estende-se da superficie do planeta até uma altitude aproximadamente de $11 \mathrm{~km}$, com uma variação de temperatura de $15^{\circ} \mathrm{C}$ na superficie do oceano até $-56^{\circ} \mathrm{C}$ na sua interface com a estratosfera. É nela que as atividades antrópicas exercem a sua maior influência, daí ser também o principal foco das pesquisas de química ambiental atmosférica (Manahan, 1999). 
A atmosfera está intimamente ligada com as outras esferas do planeta (biosfera, geosfera, hidrosfera e antroposfera), participando dos chamados ciclos biogeoquímicos (Figura 1.1). Dependendo das características regionais, tais como: vegetação, clima, solo, atividades antrópicas, etc., a composição da atmosfera pode ser diferenciada.

A crescente atividade antrópica vem causando aumento substancial de espécies traço e inserindo outras inexistentes no ambiente. Determinar a natureza e quantidade dessas espécies químicas e compreender seu transporte e suas transformações têm se tornado um desafio constante, gerando considerável volume de pesquisas.

Satisfatoriamente, nota-se uma preocupação crescente nas últimas décadas com a proteção ambiental. Para dar suporte técnico às decisões políticas no controle estratégico da poluição são necessárias pesquisas em laboratório, de campo, bem como sistemas de modelagem. A química analítica tem papel crucial na elaboração de estratégias de controle da poluição. Assim assume grande importância o desenvolvimento de metodologias analíticas de coleta e determinação que ofereçam maior sensibilidade (alguns poluentes relevantes precisam ser monitorados em níveis de parte por trilhão) e seletividade, melhor resolução temporal, menor custo, maior robustez para o trabalho em campo e facilidade de determinação simultânea de várias espécies. 


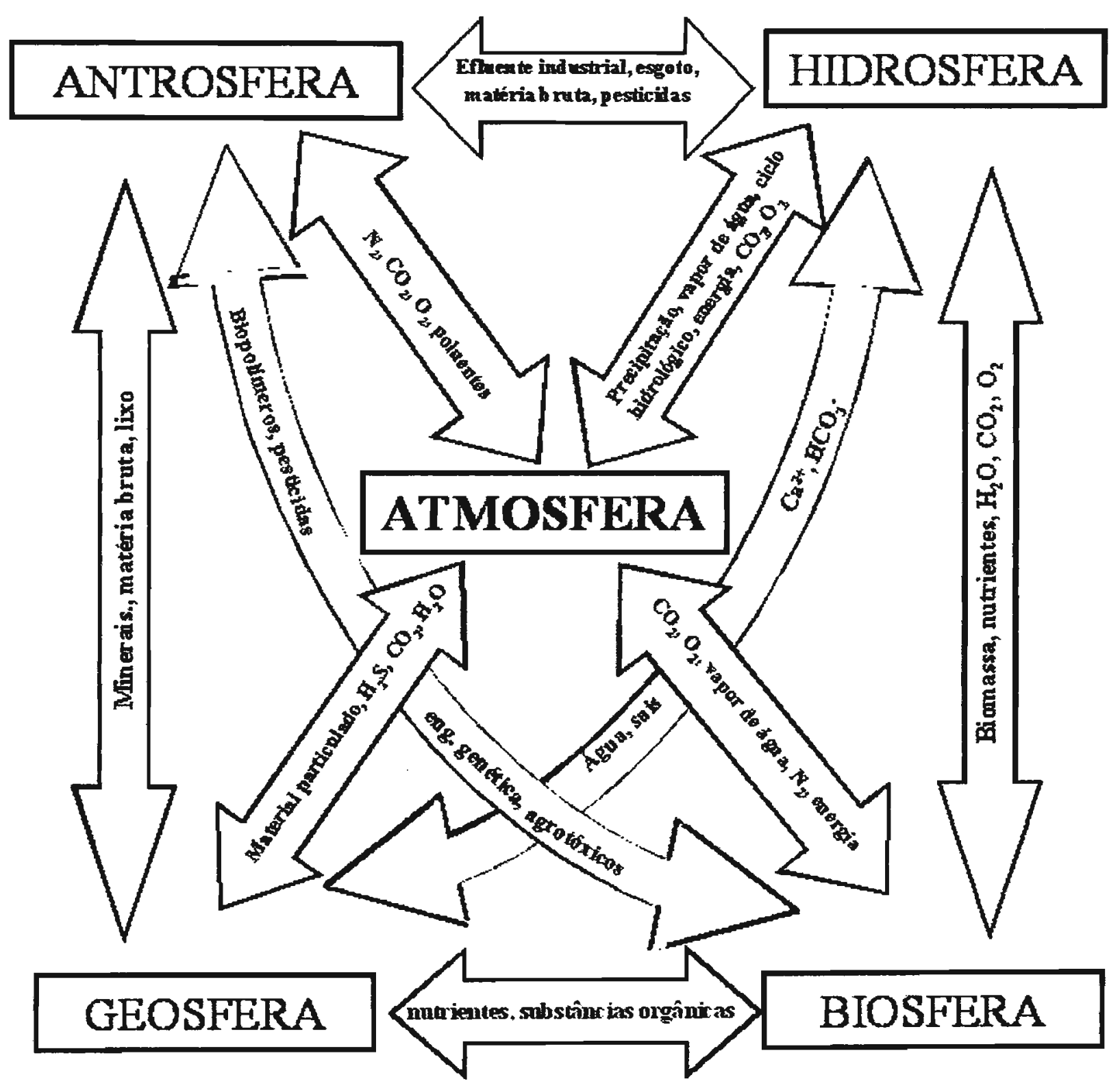

Figura 1.1 Representação entre das interações a atmosfera e as outras "esferas" do planeta (adaptado de Manahan, 1999). 


\subsection{POLUIÇÃO ATMOSFÉRICA}

Junto aos principais gases que compõe a atmosfera, existem milhares de outros compostos químicos (orgânicos e inorgânicos) em menores concentrações distribuídos nas fases líquida e gasosa ou no material particulado. Quando esses compostos encontrados no ar apresentam níveis de concentração que os tornam impróprios ou nocivos à saúde humana, aos animais ou vegetais e danosos aos materiais, são considerados poluentes atmosféricos (Seinfeld, 1986).

A preocupação com a qualidade do ar já se fazia notar com as pesquisas sobre a chuva ácida, que tiveram início no século XVII e pesquisas com ozônio e o efeito estufa, que vem sendo feitas há algumas décadas (Kowalok, 1993).

No cenário global, há reconhecimento de que as emissões descontroladas de poluentes na atmosfera não possuem fronteiras, ultrapassam a escala regional, e podem desencadear mudanças globais. Nesse contexto, programas de pesquisa ampla têm sido gerados como o International Geosphase Biosphere Program (IGBP), bem como conferências mundiais da ONU (Conferência do Rio, em 1992), Convenções do Clima, realizadas no Rio de Janeiro (1992), Berlim (1995), em Kioto (1997), Buenos Aires (1998) e a Cúpula Mundial sobre Desenvolvimento Sustentável em Johannesburgo (2002), que propiciaram grandes avanços na conscientização ambiental, porém com sérios impasses e tímidos avanços práticos na adoção de acordos internacionais de limitação de emissões (O Estado de São Paulo, 1998; Rio+10, 2002).

Usualmente os principais poluentes atmosféricos são classificados de acordo com os seguintes grupos (CETESB, 1994 e 1995): 
- Compostos de enxofre $\left(\mathrm{SO}_{2}, \mathrm{SO}_{3}, \mathrm{H}_{2} \mathrm{~S}\right.$, sulfitos);

- Compostos de nitrogênio ( $\mathrm{NO}, \mathrm{NO}_{2}, \mathrm{NH}_{3}, \mathrm{HNO}_{2}$, nitratos);

- Compostos orgânicos (hidrocarbonetos, álcoois, aldeídos, cetonas, ácidos);

- Monóxido e dióxido de carbono;

- Compostos halogenados ( $\mathrm{HCl}, \mathrm{HF}$, cloretos, fluoretos);

- Material particulado;

- Oxidantes fotoquímicos $\left(\mathrm{O}_{3}\right.$, nitrato de peroxiacetila, etc. $)$.

Vários compostos químicos são emitidos para a atmosfera por processos naturais como:

- Atividade bacteriana em solos $\left(\mathrm{N}_{2} \mathrm{O}, \mathrm{NO}\right)$;

- Atividades bacterianas sob condições anaeróbicas $\left(\mathrm{NH}_{3}, \mathrm{H}_{2} \mathrm{~S}\right.$ e $\left.\mathrm{CH}_{4}\right)$;

- Vulcões $\left(\mathrm{SO}_{2}, \mathrm{CO}\right)$;

- Oceanos (dimetil sulfeto, etc.);

- Descargas elétricas $\left(\mathrm{NO}, \mathrm{N}_{2} \mathrm{O}, \mathrm{NO}_{2}, \mathrm{O}_{3}\right)$;

- Vegetação (hidrocarbonetos, etc.).

Entre as fontes antrópicas emissoras de poluentes destacam-se os veículos automotores, calefação e produção de energia pela queima de carvão e combustíveis fósseis e em segundo plano, as emissões industriais, com destaque para as indústrias de fertilizantes, de papel, de produtos químicos diversos, refinarias de petróleo, fundições, etc. (Seinfeld, 1986; Manahan, 1999). A Tabela 1.1.1 apresenta a porcentagem relativa em volume e os principais processos de remoção de algumas dessas espécies químicas traço presentes na atmosfera (Manahan, 1999).

O material particulado ou aerossol atmosférico não tem composição química definida, podendo ser composto por várias espécies químicas orgânicas e inorgânicas, em estado sólido e/ou líquido (Seinfeld, 1986; Souza, 1998). Usualmente o material particulado no ar é classificado como tal 
quando seu diâmetro aerodinâmico é inferior a $100 \mu \mathrm{m}$ e, em apresentando diâmetro inferior a $10 \mu \mathrm{m}$, as particulas são consideradas inaláveis.

Os poluentes são classificados em dois grupos: poluentes primários emitidos diretamente pelas fontes antrópicas ou naturais e os poluentes secundários, que resultam de reações químicas do poluentes primários com outros compostos da atmosfera, inclusive os oxidantes fotoquímicos (Tabela 1.1.2) (Seinfeld, 1986; CETSB 1996).

Tabela 1.1.1 Porcentagem relativa em volume e os principais processos de remoção de algumas dessas espécies químicas traço presentes na atmosfera (Manahan, 1999).

\begin{tabular}{|c|c|c|c|}
\hline $\begin{array}{l}\text { Espécies } \\
\text { Química }\end{array}$ & $\begin{array}{c}\text { Volume } \\
\%\end{array}$ & Fontes & $\begin{array}{c}\text { Processos de } \\
\text { Remoçã̃o }\end{array}$ \\
\hline $\mathrm{CH}_{4}$ & $1,6 \times 10^{-4}$ & Biogênica & Fotoquímica \\
\hline $\mathrm{CO}$ & $1,2 \times 10^{-5}$ & $\begin{array}{l}\text { Fotoquímica, } \\
\text { antrópica }\end{array}$ & Fotoquímica \\
\hline $\mathrm{N}_{2} \mathrm{O}$ & $3 \times 10^{-5}$ & Biogênica & Fotoquímica \\
\hline $\mathrm{NO}_{\mathrm{x}}$ & $10^{-10}-10^{-6}$ & $\begin{array}{l}\text { Fotoquímica, } \\
\text { antrópica }\end{array}$ & Fotoquímica \\
\hline $\mathrm{HNO}_{3}$ & $10^{-9}-10^{-7}$ & Fotoquímica & Precipitação \\
\hline $\mathrm{NH}_{3}$ & $10^{-8}-10^{-7}$ & Biogênica & $\begin{array}{l}\text { Fotoquímica, } \\
\text { precipitação }\end{array}$ \\
\hline $\mathrm{H}_{2}$ & $5 \times 10^{-5}$ & $\begin{array}{l}\text { Biogênica, } \\
\text { Fotoquímica }\end{array}$ & Fotoquímica \\
\hline $\mathrm{H}_{2} \mathrm{O}_{2}$ & $10^{-8}-10^{-6}$ & Fotoquímica & Precipitação \\
\hline $\mathrm{HO}^{\circ}$ & $10^{-13}-10^{-10}$ & Fotoquímica & Fotoquímica \\
\hline $\mathrm{HO}_{2}{ }^{\circ}$ & $10^{-11}-10^{-9}$ & Fotoquímica & Fotoquímica \\
\hline $\mathrm{H}_{2} \mathrm{CO}$ & $10^{-8}-10^{-7}$ & Fotoquímica & Fotoquímica \\
\hline $\mathrm{CS}_{2}$ & $10^{-9}-10^{-8}$ & $\begin{array}{l}\text { Antrópica, } \\
\text { biogênica }\end{array}$ & Fotoquímica \\
\hline OCS & $10^{-8}$ & $\begin{array}{l}\text { Antrópica, } \\
\text { biogênica, } \\
\text { fotoquímica }\end{array}$ & Fotoquímica \\
\hline $\mathrm{SO}_{2}$ & $2 \times 10^{-8}$ & $\begin{array}{l}\text { Antrópica, } \\
\text { fotoquímica, } \\
\text { vulcânica }\end{array}$ & $\begin{array}{l}\text { Fotoquímica, } \\
\text { precipitação }\end{array}$ \\
\hline $\mathrm{CCl}_{2} \mathrm{~F}_{2}$ & $2,8 \times 10^{-5}$ & Antrópica & Fotoquímica \\
\hline $\mathrm{H}_{3} \mathrm{CCCl}_{3}$ & $10^{-8}$ & Antrópica & Fotoquímica \\
\hline
\end{tabular}


Tabela 1.1.2- Principais fontes de poluição do ar e principais poluentes, em região urbana (CETESB, 1995).

\begin{tabular}{|c|c|c|}
\hline \multicolumn{2}{|r|}{ Fontes } & Poluentes \\
\hline \multirow{5}{*}{$\begin{array}{l}E \\
s \\
t \\
a \\
c \\
i \\
o \\
n \\
a \\
r \\
i \\
a \\
s\end{array}$} & Combustão & $\begin{array}{l}\text { Material Particulado } \\
\text { Díxido de Enxofre e Trióxido de } \\
\text { Enxofre } \\
\text { Monóxido de Carbono, Hidrocar- } \\
\text { bonetos e Óxidos de Nitrogênio }\end{array}$ \\
\hline & Processo Industrial & $\begin{array}{l}\text { Material Particulado (fumos, poei- } \\
\text { ras, névoas) }\end{array}$ \\
\hline & \multirow[b]{2}{*}{ Queima de Resíduo Sólido } & $\begin{array}{l}\text { Gases }-\mathrm{SO}_{2}, \mathrm{SO}_{3}, \mathrm{HCL} \text {, Hidro- } \\
\text { carbonetos, Mercaptanas, } \mathrm{HF} \text {, } \\
\mathrm{H}_{2} \mathrm{~S}, \mathrm{NO}_{\mathrm{x}}\end{array}$ \\
\hline & & $\begin{array}{l}\text { Material Particulado } \\
\text { Gases }-\mathrm{SO}_{2}, \mathrm{SO}_{3}, \mathrm{HCl}, \mathrm{NOx}\end{array}$ \\
\hline & Outros & $\begin{array}{l}\text { Hidrocarbonetos, Material Particu- } \\
\text { lado }\end{array}$ \\
\hline \multirow[t]{2}{*}{ Móveis } & $\begin{array}{l}\text { Veículos Gasolina/Diesel, Äl- } \\
\text { cool, Aviōes, Motocicletas, } \\
\text { Barcos, Locomotivas etc. }\end{array}$ & $\begin{array}{l}\text { Material Particulado, Monóxido de } \\
\text { Carbono, óxidos de Enxofre, óxi- } \\
\text { dos de Nitrogênio, Hidrocarbone- } \\
\text { tos, Aldeídos, Ácidos Orgánicos }\end{array}$ \\
\hline & Naturais & $\begin{array}{l}\text { Material Particulado - Poeiras } \\
\text { Gases }-\mathrm{SO}_{2}, \mathrm{H}_{2} \mathrm{~S}, \mathrm{CO}, \mathrm{NO} \text {, } \\
\mathrm{NO}_{2} \text {, Hidrocarbonetos }\end{array}$ \\
\hline \multicolumn{2}{|c|}{$\begin{array}{l}\text { Reaçōes Químicas na Atmosfera Ex: Hi- } \\
\text { drocarbonetos + 6xidos de nitrogenio } \\
\text { (luz solar) }\end{array}$} & $\begin{array}{l}\text { Poluentes Secundarios }-\mathrm{O}_{3}, \mathrm{Al}- \\
\text { deídos, Äcidos Orgấnicos, Nitratos, } \\
\text { Orgấnicos, Aerossol Fotoquímico } \\
\text { etc. }\end{array}$ \\
\hline
\end{tabular}


Comumente, os poluentes mais comuns tais como: dióxido de enxofre $\left(\mathrm{SO}_{2}\right)$, material particulado, monóxido de carbono (CO), oxidantes fotoquímicos $\left(\mathrm{O}_{3}, \mathrm{PAN}\right.$, etc. $)$, hidrocarbonetos totais e óxidos de nitrogênio $\left(\mathrm{NO}, \mathrm{NO}_{2}\right.$ ) são utilizados como parâmetros de definição da qualidade do ar, sendo que vários deles apresentam efeitos danosos à saúde humana ou ao meio ambiente (Derísio, 1992).

Como exemplo dos danos à saúde humana, causados por poluentes primários e secundários pode-se citar:

- dióxido de enxofre - os efeitos nocivos à saúde estão associados à sua solubilidade na parede do aparelho respiratório causando infecções e agravando doenças respiratórias; se absorvido em partículas, pode ser conduzido aos alvéolos pulmonares podendo causar danos aos tecidos dos pulmões.

- monóxido de carbono - está associado à capacidade de transporte do oxigênio pelo sangue, sendo sua afinidade pela hemoglobina 210 vezes maior do que $\mathrm{o} \mathrm{O}_{2}$, forma-se a carboxihemoglobina, diminuindo a capacidade do sangue de transportar $\mathrm{O}_{2}$.

- material particulado - aumento dos efeitos fisiológicos dos gases irritantes, presença nas partículas de substâncias minerais, que possuem propriedades tóxicas e presença de compostos orgânicos, que podem ser carcinogênicos e mutagênicos.

- oxidantes fotoquímicos $\left(\mathrm{O}_{3}\right.$, PAN, formaldeído, acroleína, acetaldeído, etc.) - irritação dos olhos, redução da capacidade pulmonar e agravamento de doenças respiratórias, danos à estrutura pulmonar, menor resistência a infecções respiratórias. 
- óxidos de nitrogênio - $\mathrm{NO}_{2}$, devido a sua baixa solubilidade pode penetrar profundamente no sistema respiratório e formar nitrosaminas que são carcinogênicas.

- hidrocarbonetos policíclicos aromáticos - apresentam graus variáveis de carcinogenicidade e mutagenicidade.

O crescente aumento dos números de "alertas" difundidos por pesquisadores sobre os impactos ambientas gerados pela poluição, diagnosticados por pesquisas recentes, atribuídos ao aumento na concentração de $\mathrm{CO}_{2}$ (efeito estufa), diminuição da camada de $\mathrm{O}_{3}$, do aumento de acidez das chuvas (chuva ácida) entre outros, torna-se crucial a elaboração de estratégias no combate a emissão de poluentes para a atmosfera. Assim, necessita-se de aprofundamento nas pesquisas para que se possam elucidar as complexas etapas por que passam os poluentes; desde sua emissão até a remoção, bem como, o monitoramento dos vários poluentes para analisar a qualidade do ar e prever os impactos sobre a saúde humana e ambiental.

\subsection{OXIDANTES FOTOQUÍMICOS}

A preocupação com a qualidade do ar em áreas urbanas já se fazia notar há séculos. Em plena idade média, relatos relacionaram a queima de carvão com a poluição do ar (Brimblecombe, 1976; Levine, 1985).

Segundo Levine (1985), as espécies químicas traço na atmosfera puderam ser determinadas com confiança com os progressos desenvolvidos na instrumentação analítica que ocorreram a partir de 1930. Inúmeros gases traço foram identificados em áreas urbanas até meados de 1950, porém as relações dessas espécies químicas com reações fotoquímicas ainda não eram estabelecidas. Poucos anos após, Haagen-Smit (1952) demonstrou que $\mathrm{O}_{3}$ e outros oxidantes originavam-se de reações envolvendo $\mathrm{NO}_{2}$ e compostos 
orgânicos em presença de luz solar. Posteriormente, Levy (1971) reconheceu o papel do radical hidroxila $\left(\mathrm{OH}^{*}\right)$ no conjunto das reações fotoquímicas dos poluentes atmosféricos, uma vez que apenas as reações com $\mathrm{O}_{3}$ eram insuficientes para explicar as reações fotoquímicas entre as espécies emitidas e os produtos formados. Paralelamente, a partir da década de 60 , as pesquisas passaram a dar mais importância às interações da fase gasosa com a fase líquida e com o material particulado presente na atmosfera, buscando elucidar a formação da "chuva ácida" e dos seus efeitos sobre o meio ambiente.

Desta forma, os estudos sobre as espécies químicas e os processos que as envolvem na atmosfera passaram a envolver tanto a fase gasosa quanto a fase líquida da atmosfera, sendo que os estudos com a fase líquida de forma mais abrangente ocorreram nas décadas 60 e 70 , gerando um grande número de trabalhos sobre a "chuva ácida"

A poluição atmosférica causada por oxidantes fotoquímicos é usualmente denominada de "smog fotoquímico". A denominação genérica de oxidantes fotoquímicos é atribuída a um grupo específico de espécies químicas oxidantes originadas das reações entre compostos orgânicos e principalmente óxidos de nitrogênio, na fase gasosa da atmosfera, sob efeito da radiação solar (Seinfeld, 1986; Cardoso, 1997; EPA, 2003; Dodge, 2000; Atkinson, 2000).

No "smog fotoquímico", o ozônio é encontrado em maior proporção, sendo assim utilizado para caracterizar a poluição fotoquímica e como parâmetro em análises comparativas de outros eventos fotoquímicos. As concentrações de ozônio na baixa troposfera são consideradas adequadas quando em níveis inferiores a $0,064 \mathrm{ppm}$, moderadas de 0,065 a 0,085 ppm e de forma geral inadequadas acima de $0,085 \mathrm{ppm}$ (EPA, 2003).

A presença dos oxidantes fotoquímicos como poluentes atmosféricos ficou evidenciada a partir de 1944 através de pesquisas relacionadas aos 
danos causados pela poluição à vegetação em Los Angeles. Esses oxidantes fazem parte e também são precursores dos poluentes secundários (formados através de reações químicas entre poluentes primários e espécies naturais na atmosfera). Nocivos à saúde humana, podem causar desde irritações nos olhos, redução da capacidade pulmonar a danos na estrutura pulmonar (Finlayson-Pitts e Pitts, 1986).

A principal fonte de poluentes precursores do $\mathrm{O}_{3}$ em ambientes urbanos são os hidrocarbonetos e os $\mathrm{NO}_{\mathrm{x}}$ provenientes principalmente da queima de combustível por veículos automotores. Assim, pode-se reduzir a concentração dos oxidantes fotoquímicos na atmosfera diminuindo as emissões de seus precursores: óxidos de nitrogênio e hidrocarbonetos.

A formação dos oxidantes fotoquímicos ocorre na atmosfera através de reações fotoquímicas pela absorção de um fóton por uma molécula, íon, átomo ou radical (Levine, 1985, Cardoso, 1997). São de tipo:

$$
\mathrm{X}+\mathrm{hv}=\mathrm{X}
$$

onde $\mathrm{X}^{\bullet}$ é o estado excitado da espécie $\mathrm{X}, \mathrm{h}$ é a constante de Planck e $v$ é a freqüência de radiação. $O$ produto $h v$ determina a energia do fóton recebido.

Após a absorção, podem ocorrer os processos de colisão, fluorescência, reações diretas e dissociação, representados por ${ }^{(11)}$ :

Colisão:

$$
\mathrm{X}^{\bullet}+\mathrm{M}=\mathrm{X}+\mathrm{M}
$$

$X^{*}$ retorna ao estado fundamental após colidir com a espécie $M$.

Fluorescência: $\quad \mathrm{X}^{\bullet}=\mathrm{X}+\mathrm{h} v$

$$
\mathrm{X}^{\bullet} \text { emite } \mathrm{o} \text { fóton absorvido e retorna ao estado fundamental }
$$

Reação Direta: $\quad \mathrm{X}^{\bullet}+\mathrm{A}=\mathrm{B}+\mathrm{C}+\ldots$

$\mathrm{X}^{\bullet}$ reage com A e são formados os produtos $\mathrm{B}$ e C .

Dissociação: $\quad \mathrm{X}^{\bullet}=\mathrm{D}+\mathrm{E}$ 
$\mathrm{X}^{*}$ se dissocia, formando outras espécies químicas. Dentre os tipos de reações fotoquímicas a dissociação é a mais importante na formação de poluentes fotoquímicos por ser a principal fonte de radicais. São também chamados de fotólise ou fotodissociação.

$\mathrm{Na}$ troposfera, o ozônio é formado a partir de reações entre oxigênio molecular e atômico:

$$
\mathrm{O}+\mathrm{O}_{2}+\mathrm{M} \rightarrow \mathrm{O}_{3}+\mathrm{M}
$$

onde $\mathrm{M}$ é uma espécie química, por exemplo $\mathrm{N}_{2}$, que participa da reação sem apresentar alterações persistentes.

Em regiões com emissões antropogênicas, a principal fonte de oxigênio atômico é a fotólise do $\mathrm{NO}_{2}$ pela radiação solar.

$$
\mathrm{NO}_{2}+\mathrm{hv} \rightarrow \mathrm{NO}+\mathrm{O}
$$

Porém, devido a alta velocidade da reação entre $\mathrm{O}_{3}$ e $\mathrm{NO}$ o $\mathrm{O}_{3}$ é rapidamente consumido:

$$
\mathrm{O}_{3}+\mathrm{NO} \rightarrow \mathrm{NO}_{2}+\mathrm{O}_{2}
$$

Contudo, em atmosferas poluídas, outras reações fotoquímicas são capazes de gerar $\mathrm{NO}_{2}$ e conseqüentemente $\mathrm{O}_{3}$. Entre elas, a mais abundante é a conversão de $\mathrm{NO}$ em $\mathrm{NO}_{2}$ através das reações entre o radical livre hidroxila $\left(\mathrm{OH}^{\circ}\right)$ e os hidrocarbonetos $(\mathrm{RH})$ :

$$
\begin{aligned}
& \mathrm{HO}^{\bullet}+\mathrm{RH} \rightarrow \mathrm{R}+\mathrm{H}_{2} \mathrm{O} \\
& \mathrm{R}+\mathrm{O}_{2} \rightarrow \mathrm{RO}_{2} \\
& \mathrm{RO}_{2}+\mathrm{NO} \rightarrow \mathrm{NO}_{2}+\mathrm{RO} \\
& \mathrm{RO}^{\cdot}+\mathrm{O}_{2} \rightarrow \mathrm{R}^{\prime} \mathrm{CHO}+\mathrm{HO}_{2} \\
& \mathrm{HO}_{2}+\mathrm{NO} \rightarrow \mathrm{NO}_{2}+\mathrm{HO}^{\circ}
\end{aligned}
$$


$\mathrm{O}$ radical livre hidroxila pode ser formado a partir da fotólise de $\mathrm{O}_{3}$, $\mathrm{HNO}_{2}$ e $\mathrm{H}_{2} \mathrm{O}_{2}$ (Finlayson-Pitts e Pitts, 1986).

$$
\begin{aligned}
& \mathrm{O}_{3}+\mathrm{h} v \rightarrow \mathrm{O}+\mathrm{O}_{2} \\
& \mathrm{O}+\mathrm{H}_{2} \mathrm{O} \rightarrow 2 \mathrm{HO}^{\circ} \\
& \mathrm{HNO}_{2}+\mathrm{h} v \rightarrow \mathrm{HO}^{\circ}+\mathrm{NO} \\
& \mathrm{H}_{2} \mathrm{O}_{2}+\mathrm{h} v \rightarrow 2 \mathrm{HO}^{\circ}
\end{aligned}
$$

$\mathrm{O}$ peróxido de hidrogênio $\left(\mathrm{H}_{2} \mathrm{O}_{2}\right)$, principal oxidante de $\mathrm{HSO}_{3}{ }^{-}$à $\mathrm{H}_{2} \mathrm{SO}_{4}$ na fase líquida da atmosfera, resulta do desproporcionamento de radicais hidroperoxila $\left(\mathrm{HO}_{2}{ }^{\circ}\right)$.

$$
\mathrm{HO}_{2}{ }^{\circ}+\mathrm{HO}_{2}{ }^{-} \rightarrow \mathrm{H}_{2} \mathrm{O}_{2}+\mathrm{O}_{2}
$$

Por sua vez, o radical hidroperoxila $\left(\mathrm{HO}_{2}{ }^{\circ}\right)$ é produto da fotólise de aldeídos, principalmente o formaldeído:

$$
\begin{aligned}
& \mathrm{HCHO}+\mathrm{hv} \rightarrow \mathrm{H}+\mathrm{HCO}^{\circ} \\
& \mathrm{HCO}^{-}+\mathrm{O}_{2} \rightarrow \mathrm{HO}_{2}^{*}+\mathrm{CO}^{\circ}
\end{aligned}
$$

Preferencialmente, na fase gasosa da atmosfera o radical hidroxila $\left(\mathrm{HO}^{\circ}\right)$ pode reagir com $\mathrm{NO}_{2}$, formando o $\mathrm{HNO}_{3}$ :

$$
\mathrm{HO}^{\circ}+\mathrm{NO}_{2} \rightarrow \mathrm{HNO}_{3}
$$


Através das reações do acetaldeído e $\mathrm{HO}^{*}$ em presença de $\mathrm{NO}_{2}$ e $\mathrm{O}_{2}$, ocorre a formação do nitrato de peroxiacetila (PAN) (Baird, 1995):

$$
\begin{aligned}
& \mathrm{CH}_{3} \mathrm{CHO}+\mathrm{HO}^{\bullet} \rightarrow \mathrm{CH}_{3} \mathrm{CO}+\mathrm{H}_{2} \mathrm{O} \\
& \mathrm{CH}_{3} \mathrm{CO}+\mathrm{O}_{2} \rightarrow \mathrm{CH}_{3} \mathrm{C}(\mathrm{O})-\mathrm{O} \\
& \mathrm{CH}_{3} \mathrm{C}(\mathrm{O})-\mathrm{O}_{2}+\mathrm{NO}_{2} \rightarrow \mathrm{CH}_{3} \mathrm{C}(\mathrm{O})-\mathrm{OO} \mathrm{NO}_{2}
\end{aligned}
$$

A dependência entre as espécies que compõe o smog fotoquímico e a intensidade da luz solar fica evidenciada na Figura 1.2.1.

A Figura 1.2.2, apresenta as principais reações fotoquímicas envolvendo a formação de poluentes como PAN, $\mathrm{O}_{3}, \mathrm{HNO}_{3}$ e $\mathrm{NO}_{2}$ (Rocha, F.R., 1999). 


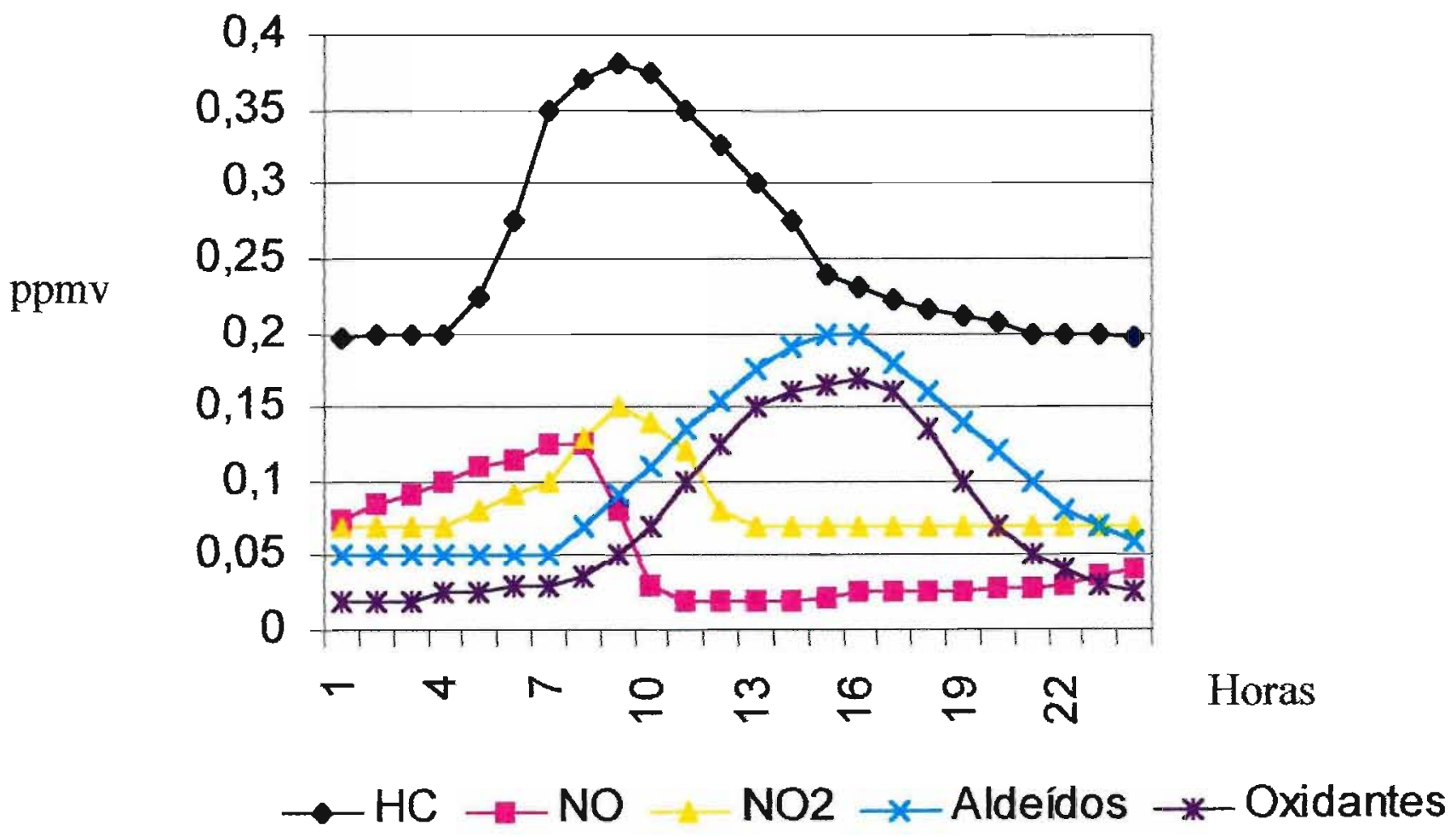

Figura 1.2.1 Gráfico de algumas espécies químicas presentes no smog fotoquímico, em função de um período de 24h (Manahan, 1999). 


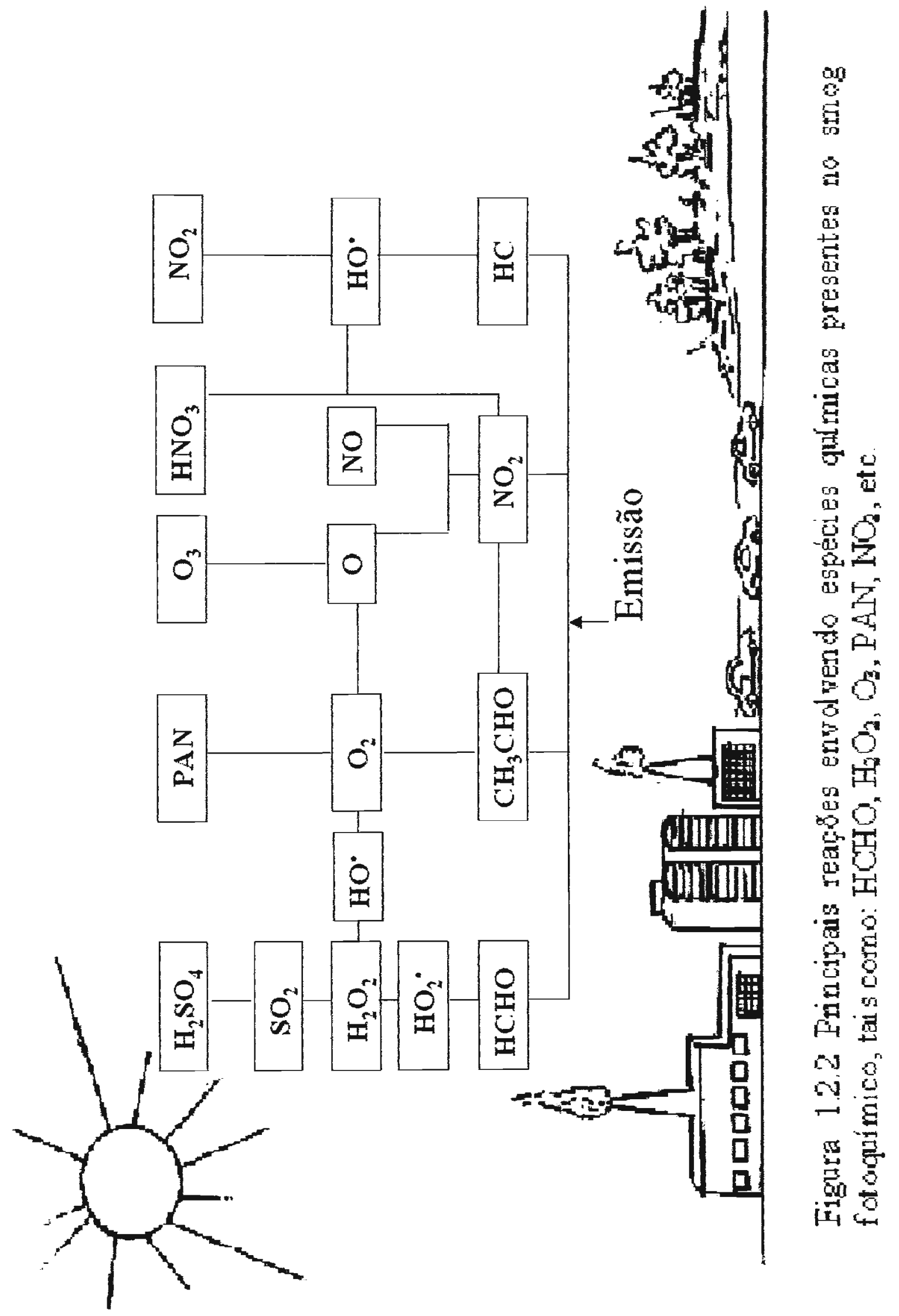




\subsection{REMOÇÃO DE POLUENTES ATMOSFÉRICOS}

Os poluentes na atmosfera podem ser removidos por três formas distintas: processos físicos, reações químicas e atividades biológicas (Segundo, 1997; Seinfeld, 1986).

A remoção por processos fisicos ocorre pela deposição seca e/ou deposição úmida. A deposição seca se caracteriza pela sedimentação gravitacional e pela sorção física ou química dos poluentes através de processos difusionais em superficies como solo, águas e vegetações; predomina nas regiões próximas das fontes emissoras de poluentes (Sehmel, 1980; Voldner et al., 1986). A sedimentação gravitacional é eficiente para partículas com diâmetro maior do que $10 \mu \mathrm{m}$ (Finlayson-Pitts e Pitts, 1986).

De maneira geral, em regiões urbanas com acentuadas atividades antrópicas a deposição seca acaba prevalecendo como principal mecanismo de remoção de poluentes, enquanto em regiões rurais costuma haver alternância de predomínio da deposição seca ou úmida dependendo do regime de chuvas. Ainda, em regiões remotas onde não há atividades antrópicas, a deposição úmida tende a prevalecer como processo de remoção (Keuken, 1989).

A deposição úmida pode dar-se na forma de chuva, neblina, neve, granizo e garoa. Na chuva, pode-se distinguir dois processos o "rainout" e o "washout". O "rainout" consiste em chuva decorrente de nuvens em cuja gênese o material particulado serviu de núcleo primário de condensação ou nuvens que absorveram gases ou apresentaram impactação com material particulado. Já o "washout" consiste no arraste dos poluentes (gasosos e material particulado) durante a queda das gotas de chuva (Mohnen, 1988; Charson et al., 1983). A deposição úmida é mais eficiente na remoção de 
espécies gasosas solúveis em água, se bem que material particulado pode ser removido por impactação ou quando este funciona como núcleo primário de condensação das gotas.

O tempo de "vida" de uma espécie química na atmosfera depende do processo global de emissão/transporte/transformação/remoção situando-se, tipicamente, entre frações de segundos e vários anos (Seinfeld, 1986; Gauri et al., 1983). O transporte dos poluentes, dependendo das condições meteorológicas e da altura das emissões dos poluentes pode alcançar alguns quilômetros no sentido vertical e algumas centenas de quilômetros no sentido horizontal (Levine et al., 1982; Gaffney et al., 1987). Durante o transporte uma significativa parte dos gases emitidos passa a formar aerossóis através de reações químicas na atmosfera e posterior condensação (Whitby, 1978).

As transformações químicas na atmosfera envolvem oxidações nas fases líquida e gasosa e reações fotoquímicas, muitas vezes favorecendo a remoção de espécies que teriam um tempo de "vida" maior na atmosfera, caso não participassem de processos reativos. Serve como exemplo o $\mathrm{SO}_{2}$ que tem tempo de vida de 1 a 2 dias na atmosfera; se for oxidado a ácido sulfúrico, na fase liquida ou na formação de aerossóis, pode ser removido com maior rapidez da atmosfera (Schwartz, 1989).

A remoção úmida de poluentes da atmosfera gera o fenômeno que ficou conhecido como deposição ácida, responsável por diversos danos aos organismos vivos, ao meio ambiente de forma geral e aos materiais (Ulrich, 1984; Johnson et al., 1983, Camuffo et al., 1983, Cowling, 1982; Acid Rain, 1983). Na Figura 1.3.1, estão resumidos alguns processos globais que envolvem desde a emissão, o transporte e a remoção de poluentes da atmosfera. 


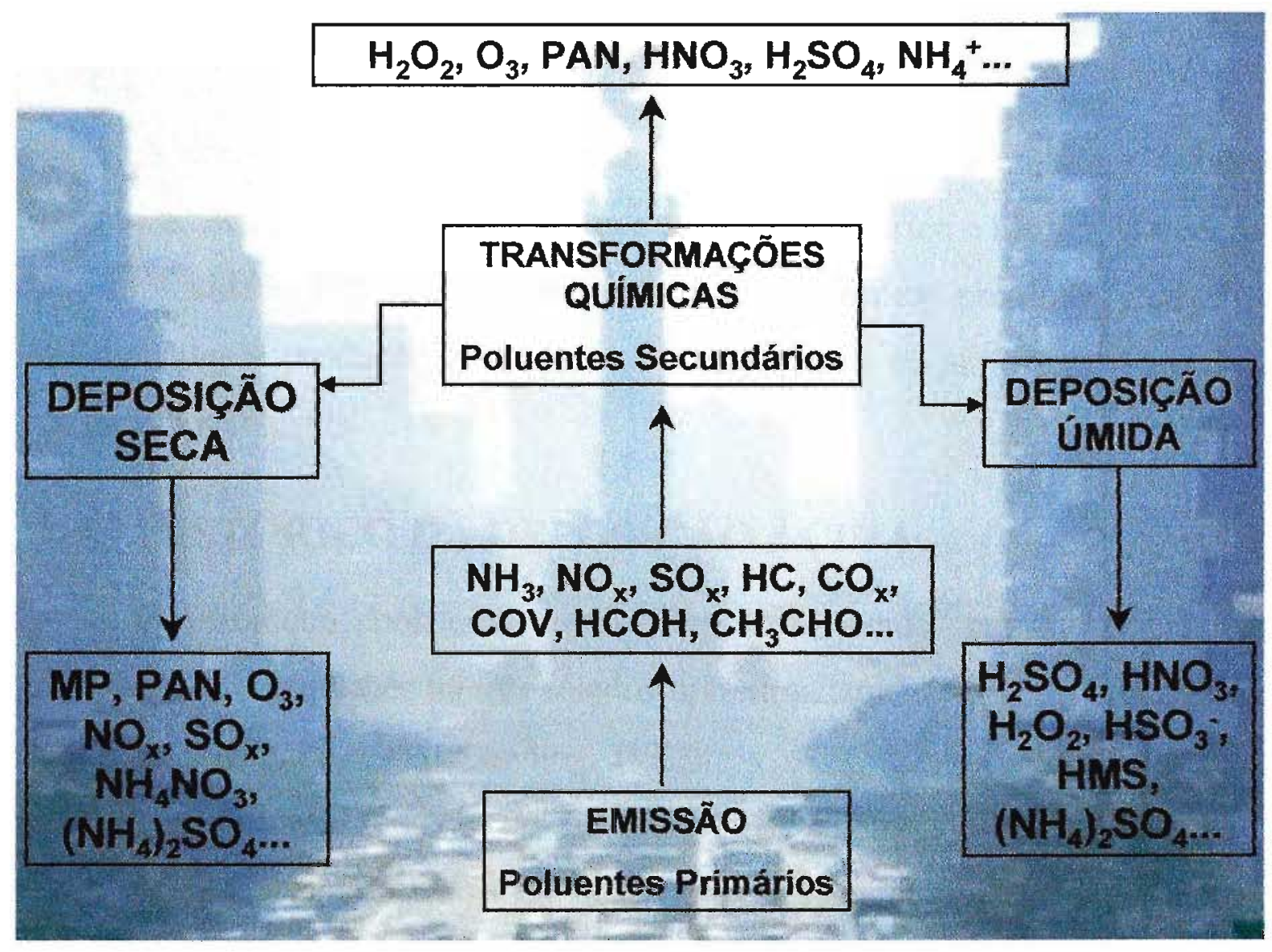

Figura 1.3.1 Emissão e remoção de alguns poluentes primários e secundários da atmosfera. 


\subsection{CHUVA ÁCIDA}

$\mathrm{Na}$ ausência de emissões antrópicas e de atividades naturais como vulcões, as precipitações úmidas em regiões remotas, apresentam $\mathrm{pH}$ em torno de 5,6. Essa acidez natural é devida ao equilíbrio de água de chuva com - $\mathrm{CO}_{2}$ atmosférico (pressão parcial de 0,00035 atm a $25^{\circ} \mathrm{C}$ ) (Charlson et al., 1982).

A chuva ácida ou deposição ácida tem sido alvo de inúmeros estudos, quanto ao seu $\mathrm{pH}$, condutividade, teor de ácidos sulfúrico e nítrico, bem como a complexidade e diversidade das substâncias químicas presentes, que estão relacionadas à produção de oxidantes fotoquímicos na atmosfera e remoção de espécies solúveis.

\subsubsection{HISTÓRICO DA DEPOSIÇÃO ÁCIDA}

O fenômeno conhecido como "Deposição Ácida" tem sido objeto de estudos e preocupações há três séculos aproximadamente (Briblecombe et al., 1982; Briblecombe, 1987; Cowling, 1982).

$\mathrm{Na}$ segunda metade do século XVII na Inglaterra, pesquisadores observaram os efeitos causados pelas emissões de poluentes industriais na vegetação e na saúde humana; iniciando uma série de trabalhos sobre deposição ácida que se desencadearam nos próximos séculos (Smith, 1872; Segundo, 1997; Keuken, 1989). Nestes estudos iniciais, a poluição da atmosfera foi relacionada com a queima de carvão como fonte de energia industrial e aquecimento doméstico.

A observação dos drásticos efeitos da deposição ácida, levou pesquisadores a estudos sistemáticos sobre poluição no século XIX, com medições de precipitações ocorridas na Alemanha, Inglaterra e França. Cabe ressaltar, que os estudos da deposição ácida também investigavam uma 
possível relação entre a fertilização do solo e os compostos de nitrogênio, presentes na deposição ácida oriundos da atmosfera. Posteriormente, os estudos com a chuva ácida foram redirecionados, objetivando-se a caracterização da poluição do ar. Ainda nesse século, o termo "Chuva Ácida" é empregado pioneiramente por Smith (1872) na Inglaterra em seu livro, no qual caracteriza o fenômeno (Segundo 1997; Smith, 1872). Na Alemanha, observou-se o declínio das florestas próximas às indústrias metalúrgicas (fundições), onde os danos a vegetação foram atribuídos a presença de $\mathrm{SO}_{2}$ nos estômatos das plantas mediante umidade, provenientes da deposição ácida (Keuken, !989; Ulrich, B., 1984).

Após a II Guerra Mundial houve substancial aumento na produção de energia e alimentos, paralelamente ao desenvolvimento econômico, o que levou a um acréscimo significativo nas emissões de poluentes. Dentre os poluentes emitidos, $\mathrm{o} \mathrm{SO}_{2}$ é de particular importância por ter sido apontado como um dos principais responsáveis pela chuva ácida. Estudos em regiões remotas no Ártico Canadense mostraram um aumento da acidez de cerca de $75 \%$ no período entre 1956 e 1977 em relação a primeira metade do século (Barrie et al., 1985). Considera-se como fator principal a esse aumento da acidez, o transporte a longa distância da poluição do ar oriundos de regiões industrializadas para outras remotas.

No continente Europeu, em função do aumento das atividades agrícolas, estima-se que a concentração de amônia na atmosfera dobrou entre 1870 e 1980 (Asman, 1988).

A observação da acidificação de lagos nos países escandinavos e na América do Norte deu início a uma série de pesquisas relacionadas a deposição ácida (Likens et al., 1974; Oden, 1968). Na Europa e na América do Norte, redes de monitoramento em grande escala foram implantadas na década de 50 para medições de poluentes tanto na fase gasosa da atmosfera 
quanto na fase líquida (Rossby et al., 1955; Ottar, 1978; Vermeulen, 1978; Baker et al., 1981; Barrie et al., 1984).

No Brasil, os estudos sobre a composição química da atmosfera foram enfatizados na década de 80 (Orsini et al.., 1986; Ferreira e Moreira Nordemann, 1984; Haag, 1985; Forti et al., 1988). Porém, ainda não existe rede de monitoramento estabelecida, os estudos sobre poluição atmosférica concentram-se nos esforços de alguns pesquisadores. Na região de São Paulo, principal pólo econômico do país, a CETESB vem desde 1976 intensificando esforços pra a melhoria da qualidade do ar através do monitoramento dos principais poluentes urbanos $\mathrm{e}$ de ações preventivas. Dentre as conseqüências, registrou-se uma sensível redução do $\mathrm{SO}_{2}$, desde a década de 80, mantendo-se atualmente abaixo dos limites permitidos (CETESB, 1997).

\subsubsection{CONSIDERAÇÕES SOBRE CHUVA ÁCIDA}

A chuva contribui na remoção de muitos poluentes da troposfera. Desta forma, a composição da água da chuva depende das emissões e das condições meteorológicas, tais como, a direção dos ventos, o fluxo da chuva, diferenças sazonais, massas de ar continentais e marítimas, etc. Os impactos ambientais ocasionados pela chuva poluída, usualmente designada de chuva ácida, são significativos em diversas regiões do planeta, razão pela qual foram estabelecidos programas de pesquisa, monitoramento e redução nas emissões.

Em regiões submetidas à interferência humana, o aumento da acidez deve-se principalmente pelo teor de ácidos sulfúrico, nítrico, carboxilícos $\mathrm{e}$ outros de menor impacto. Esses poluentes têm como principais precursores os óxidos de nitrogênio e de enxofre, hidrocarbonetos e compostos com grupo carbonila, podendo ser formados tanto em reações na fase gasosa quanto na 
fase heterogênea da atmosfera (Cowling, 1982; Gatz, 1991; Losno et al., 1991; Mage et al., 1996).

As fontes naturais de $\mathrm{NO}_{\mathrm{x}}$ incluem principalmente atividades por microorganismos no solo, queimadas naturais, descargas elétricas na atmosfera, pela oxidação de $\mathrm{NH}_{3}$ (origem biogênica) por radicais hidroxila $\left(\mathrm{HO}^{\circ}\right)$ em fase gasosa. As principais fontes antrópicas de $\mathrm{NO}_{\mathrm{x}}$ são as indústrias e veículos automotores, através da combustão de combustível fóssil. Devido à baixa solubilidade do $\mathrm{NO}_{2}$ em água, este é oxidado a $\mathrm{HNO}_{3}$ preferencialmente em fase gasosa (Albuquerque, 1993, Galvão, 1996):

$$
\mathrm{NO}_{2}+\mathrm{HO}^{\bullet} \rightarrow \mathrm{HNO}_{3}
$$

Por outro lado, o ácido sulfúrico forma-se predominantemente na presença de umidade e de peróxido de hidrogênio, através da oxidação de $\mathrm{SO}_{2}$ por $\mathrm{H}_{2} \mathrm{O}_{2}$ em fase líquida.

As fontes naturais de compostos de enxofre são principalmente: atividades biológicas no solo, pântanos e oceanos; "spray" marinho; vulcões e se apresentam como $\mathrm{H}_{2} \mathrm{~S}, \mathrm{CS}_{2}$, OCS, sulfetos orgânicos como $\left(\mathrm{CH}_{3}\right)_{2} \mathrm{~S}$ e $\left(\mathrm{CH}_{3}\right)_{2} \mathrm{~S}_{2}$ e $\mathrm{SO}_{2}$ (Cardoso et al., 1992). As principais fontes antrópicas de compostos de enxofre vêem da queima de combustíveis fósseis, na forma de $\mathrm{SO}_{2}$; as emissões antrópicas contribuem com cerca de $70 \%$ comparado com as naturais (Charlson et al., 1982).

Em atmosferas úmidas o ácido sulfúrico é formado, preferencialmente, na fase aquosa pela oxidação do $\mathrm{SO}_{2}$ e entre os oxidantes, $\mathrm{H}_{2} \mathrm{O}_{2}$ é o de maior importância em pH inferior a 5 (Seinfeld, 1986). A oxidação do $\mathrm{SO}_{2}$ pelo $\mathrm{H}_{2} \mathrm{O}_{2}$ em fase líquida ocorre, simplificadamente (Gunz et al., 1990): 


$$
\begin{aligned}
& \mathrm{SO}_{2}+\mathrm{H}_{2} \mathrm{O} \rightarrow \mathrm{SO}_{2} \cdot \mathrm{H}_{2} \mathrm{O} \\
& \mathrm{SO}_{2} \cdot \mathrm{H}_{2} \mathrm{O} \rightarrow \mathrm{H}^{+}+\mathrm{HSO}_{3}^{-} \\
& \mathrm{HSO}_{3}^{-}+\mathrm{H}_{2} \mathrm{O}_{2} \rightarrow \mathrm{SO}_{2} \mathrm{OOH}+\mathrm{H}_{2} \mathrm{O} \\
& \mathrm{SO}_{2} \mathrm{OOH}+\mathrm{H}^{+} \rightarrow \mathrm{H}_{2} \mathrm{SO}_{4}
\end{aligned}
$$

$\mathrm{Na}$ fase gasosa, $\mathrm{o}_{2} \mathrm{SO}_{4}$, forma-se principalmente pela oxidação de $\mathrm{SO}_{2}$ pelo radical hidroxila ( $\mathrm{HO}^{\circ}$ ) (Gaffney et al., 1987; Calvert et al., 1978; Stockwell et al., 1983).

$$
\mathrm{SO}_{2}+\mathrm{HO}^{\bullet}+\mathrm{M} \rightarrow \mathrm{HOSO}_{2}+\mathrm{M}
$$

a espécie $\mathrm{HOSO}_{2}$ é oxidada a $\mathrm{SO}_{3}$, o qual reage com $\mathrm{H}_{2} \mathrm{O}$ para formar $\mathrm{H}_{2} \mathrm{SO}_{4}$ :

$$
\begin{aligned}
& \mathrm{HOSO}_{2}+\mathrm{O}_{2} \rightarrow \mathrm{SO}_{3}+\mathrm{HO}_{2} \\
& \mathrm{SO}_{3}+\mathrm{H}_{2} \mathrm{O} \rightarrow \mathrm{H}_{2} \mathrm{SO}_{4}
\end{aligned}
$$

$\mathrm{O} \mathrm{H}_{2} \mathrm{SO}_{4}$ formado pode ser absorvido pelas gotas de água de chuva ou pode reagir com $\mathrm{NH}_{3}$, sofrer deposição seca, ou atuar como núcleo de condensação de vapor d'água (Fornaro, 1991). Os ácidos sulfúrico e nítrico, em atmosfera com $\mathrm{NH}_{3}$, podem ser neutralizados formando sais de amônio como $\left(\mathrm{NH}_{4}\right) \mathrm{HSO}_{4},\left(\mathrm{NH}_{4}\right)_{2} \mathrm{SO}_{4}$ e $\mathrm{NH}_{4} \mathrm{NO}_{3}$.

Outra parcela significativa na acidez das águas de chuva é atribuída aos ácidos carboxílicos, responsáveis por 16 a $35 \%$ da acidez total, sendo mais abundantes os ácidos fórmico e acético (Souza, 1998).

Os ácidos carboxílicos são emitidos para a atmosfera por fontes antrópicas (queima de combustível fóssil, queimadas provocadas e incineração de matéria orgânica); naturais (biossíntese de bactérias, fungos, 
insetos e plantas) e por reações fotoquímicas com poluentes primários (Souza, 1998).

Em regiões densamente urbanizadas e industrializadas, com altas taxas de emissão de óxidos de enxofre e óxidos de nitrogênio, o pH das chuvas ácidas chega a valores inferiores a 4,5 e em regiões críticas pode, ocasionalmente, chegar a 2,0 .

Os danos causados pela chuva ácida são abrangentes e atingem desde ecossistemas terrestres e aquáticos a degradações na construção civil (Fornaro, 1991; Graham \& Trotman, 1983).

Nos ecossistemas terrestres é importante salientar o declínio de florestas em nações industrializadas e vizinhas (particularmente na Alemanha e em algumas regiões montanhosas dos EUA). Nesse ambiente, as árvores perdem as folhas e os brotos acarretando danos permanentes em seu crescimento e produtividade, principalmente pela perda de nutrientes como cálcio, potássio, magnésio e outros elementos das superficies das plantas que são deslocados pela deposição ácida, evidenciando o desgaste foliar; também, as lesões necróticas sobre as folhas, bem como a destruição das células epidérmica e a erosão da cutícula, fazem parte desses danos (Graham \& Trotman, 1983). Também, são notados os desaparecimentos de líquens e fungos, importantes no papel de decompositores orgânicos.

A redução do $\mathrm{pH}$ no solo pela chuva ácida provoca alterações na fertilidade e na produtividade por lixiviar o cálcio e o magnésio, nutrientes importantes para a vegetação. $\mathrm{O}$ excesso de $\mathrm{H}^{+}$libera, através da troca iônica, metais pesados que estavam em partículas coloidais no solo e em rochas, mesmo em pequenas quantidades esses metais são tóxicos para as plantas, animais e microorganismos, podendo também, afetar os mananciais. Em pH menor do que 5,0 podem ser encontradas concentrações fitotóxicas de metais, com inibição do desenvolvimento de brotos de leguminosas e redução 
na atividade bacteriana que fixam o nitrogênio. A quantidade de substâncias húmicas que serve como ligante para os metais, especialmente o alumínio, também é dependente da acidez.

A mobilização do alumínio pela deposição ácida é um fator de modo geral preocupante, podendo causar a intoxicação de vegetais ou determinar alteraçôes das espécies do ecossistema afetado. Diferentemente do Brasil, a mobilização natural do aluminio é pequena na maioria dos solos Europeus, dado tamponamento do solo com calcário. Entretanto, mesmo em solos secos Europeus, como é o caso da Holanda que apresentam de 5 a $10 \mathrm{~g}$ de cálcio por quilograma a deposição ácida provocou em 1989 acentuada redução do cálcio ( $0,3 \mathrm{~g}$ por quilograma), um nível muito abaixo da necessidade daquele ecossistema, acarretando a extinção de algumas espécies na região (Atkins, 1997).

Os ecossistemas aquáticos geralmente apresentam pH em torno de 6,0 a 8,0. O aumento da acidez provocou perdas nas populações de peixes em rios e lagos da Escandinávia, América do Norte, Escócia, Inglaterra, etc. Também, são notadas mutações e/ou perdas no fitoplâncton, zooplâncton e animais bentônicos, bem como, desequilíbrio no ciclo de nutrientes, perda dos decompositores de matéria orgânica e diminuição da biodiversidade (Graham \& Trotman, 1983).

No Brasil, a deposição ácida nas regiões próximas às cidades de Cubatão e São Paulo tem produzido danos em larga escala em uma das florestas mais complexas e ricas em biodiversidade que se conhece, a Mata Atlântica. A região industrial de Cubatão é uma das mais poluídas do planeta, sendo que a adoção de tecnologias menos poluentes pelas empresas abrandou mas não eliminou o problema, como mostram estudos de caracterização das emissões, do transporte e da deposição dos poluentes posteriores à modernização das indústrias (Klockow et al., 1997), havendo necessidade de 
aprofundá-los e de desencadear ações adicionais para minimizar os impactos ambientais e na saúde humana

$\mathrm{Na}$ construção civil, ocorre corrosão na maioria dos metais e decomposição de materiais que agregam arenitos ou calcários.

Chuvas alcalinas são menos freqüentes mas podem ocorrer, por exemplo, quando há prevalência de emissões de $\mathrm{NH}_{3}$, apresentando $\mathrm{pH}$ superior a 7,0 .

\subsection{POLUIÇÃO ATMOSFÉRICA NA REGIÃO METROPOLI- TANA DE SÃO PAULO}

O crescimento demográfico nas últimas décadas levou a um enorme aglomerado populacional nos centros urbanos. No Brasil, os índices de urbanização foram altos no século passado chegando a $55,9 \%$ na década de 70 e 75,6\% na década de 90. Na região mais desenvolvida do país, a sudeste, os índices alcançaram $88 \%$ em 1991. A concentração populacional e dos processos produtivos, aliados ao desenvolvimento desordenado e falta de conscientização ambiental nos centros urbanos geraram, entre outros graves problemas, altíssimos índices nos níveis de poluição atmosférica.

Dentre as regiões mais prósperas e também mais poluídas do Brasil encontra-se a Região Metropolitana de São Paulo (RMSP), cuja qualidade do ar é determinada pela interação entre a fontes de emissão de poluentes móveis (veículos automotores) e estacionárias (indústrias), pelas condições climáticas e pela topografia da região.

A RMPS localiza-se no Planalto Atlântico, mais especificamente no compartimento rebaixado conhecido como Bacia Sedimentar de São Paulo, 
ocupando uma área de aproximadamente $8000 \mathrm{~km}^{2}$ com altitudes que variam de 650 a $1200 \mathrm{~m}$.

Como principal pólo econômico do país e um dos maiores conglomerados humanos do mundo (cerca de 18 milhões de habitantes), a RMSP apresenta um dos maiores e mais graves problemas de poluição atmosférica do país. A forte degradação da qualidade do ar da RMSP é causada pelas emissões de poluentes lideradas pela enorme frota de cerca de 6,0 milhões de veículos automotores e em segundo lugar por um parque industrial com mais de 30.000 unidades (CETESB, 2001).

Desta forma, a poluição do ar em São Paulo tem sido objeto de extensivos estudos realizados principalmente por Universidades e órgãos governamentais. Desde a década de 70 , a CETESB mantém redes de monitoramento que permitem a medição de poluentes para avaliação da qualidade do ar e a partir de 1976 implementou a "Operação Inverno", projeto que consistia de ações preventivas e corretivas visando proteger a saúde da população contra episódios agudos da poluição do ar. Entretanto, apesar da importante contribuição na avaliação da qualidade do ar oriunda das análises químicas da deposição úmida, ainda não há redes de monitoramento para a fase líquida da atmosfera (CETESB, 2002).

Segundo a CETESB (2001), atualmente as emissões veiculares são responsáveis por mais de $90 \%$ dos aproximadamente 2,7 milhões de toneladas de poluentes lançados anualmente à atmosfera, sendo: 1,7 milhões de toneladas correspondem as emissões de $\mathrm{CO}$, o principal poluente, $390 \mathrm{mil}$ toneladas de NOx, 395 mil toneladas de hidrocarbonetos, 40 mil toneladas de SOx e 65 mil toneladas de material particulado. Porém, na década de 70 , as indústrias foram as maiores fontes de poluição, principalmente de $\mathrm{SO}_{2}$ e material particulado. 
Com o avanço tecnológico dos motores a explosão, e o uso dos catalisadores nos escapamentos, os veículos automotores novos reduziram significativamente as emissões de poluentes na última década, sendo essa redução de mais de $90 \%$ para alguns poluentes. Porém, estima a CETESB que $70 \%$ da frota veicular ainda não esta ambientalmente adequada e são responsáveis por $76 \%$ da poluição atmosférica gerada pelos veículos.

As diretrizes legais para a contenção das emissões de poluentes foram elaboradas pelo Programa Nacional de Poluição do Ar por Veículos Automotores (PROCONVE). Criado em 1986 pelo Conselho Nacional do Meio Ambiente (CONAMA) e foi implantado e operacionalizado pela CETESB em nível nacional. Como conseqüência da implantação desses programas, atualmente a CETESB registrou uma tendência de diminuição dos altos níveis de concentração de monóxido de carbono, fumaça preta e material particulado, porém em dias desfavoráveis à dispersão, ainda ocorram episódios que excedam os padrões legais de qualidade do ar.

Cabe ressaltar, que processo inverso esteja ocorrendo com $\mathrm{O}_{3}$, o qual ultrapassou o limite do padrão da qualidade do ar permitido pelo CONAMA em 78 dias $(21,4 \%)$ em 2001. Nestas condições desfavoráveis à saúde e ao meio ambiente, restringir as emissões de $\mathrm{NO}_{\mathrm{x}}$ e hidrocarbonetos, principais poluentes precursores do $\mathrm{O}_{3}$, torna-se imprescindível. Como meta no combate a poluição, espera-se uma diminuição nas emissões veiculares de poluentes com a implantação do PIV (Programa de Inspeção Veicular Ambiental) em 2003 (AmbienteSPa, 2002).

A poluição atmosférica não possui fronteiras, através dos deslocamentos das massas de ar, regiões com altos índices de degradação na qualidade do ar exportam poluentes para outras regiões. Transpondo fronteiras, os danos causados pela poluição atmosférica não ficam restritos 
apenas a região emissora, podendo afetar desde municípios vizinhos até regiões em outros continentes.

Segundo estudos multidisciplinares atuais do projeto "Meteorologia e Poluição Atmosférica em São Paulo" desenvolvido em conjunto por pesquisadores da USP do IAG, IQ, IF e IPEN, a RMSP exporta poluentes num raio abrangente de até $400 \mathrm{~km}$ de distância. Casos mais drásticos, são de cidades situadas a cerca de $100 \mathrm{~km}$ da capital que podem ter sua carga de poluentes acrescida em até $30 \%$ proveniente da exportação emitida pela RMSP. Também, em regiões próximas como Cantareira, Jaraguá e Embu as concentrações de $\mathrm{O}_{3}$ podem chegar a uma concentração $50 \%$ maior do que as encontradas no centro de São Paulo. Esse deslocamento de poluentes deve-se principalmente ao fato de que em $70 \%$ dos dias do ano os ventos que atingem a RMSP são provenientes da região sudeste (litoral) em direção ao interior de São Paulo (AmbienteSP b, 2002).

Em recentes pesquisas do departamento de Poluição Atmosférica da Faculdade de Medicina da USP, concluiu-se que o risco de morte por doenças respiratórias pode aumentar em até $12 \%$ em dias de pico de contaminação do ar e pode aumentar de $25 \%$ na procura de atendimento em prontos socorro infantis em dias subseqüentes a ocorrência de elevadas concentrações de poluentes atmosféricos. Também, uma exposição prolongada por meses ou anos, mesmo em níveis relativamente baixos de poluição, pode provocar doenças das vias respiratórias (Conceição, 2001, Pereira, 2001, AmbienteSP c, 2002). Pesquisas realizadas na FM-USP relacionam um maior número de mortes fetais tardias com dias do ano com altos índices de poluição.

Os efeitos da má qualidade do ar da RMSP sobre a saúde da população, acabam tendo reflexos também na produção e na economia da região, ao afastar temporariamente ou definitivamente moradores com problemas de saúde, ou mesmo abreviar a sua vida. 
Apesar dos efeitos da poluição atmosférica sobre a saúde humana serem alvo de preocupações e pesquisas em todos os grandes centros urbanos e industriais do mundo, as singularidades de cada região determinam a necessidade de estudos e soluções locais. 


\section{CAPÍTULO II - JUSTIFICATIVA E OBJETIVOS}




\subsection{JUSTIFICATIVA}

$\mathrm{O}$ aumento da acidez na atmosfera, em regiões submetidas à interferência humana, deve-se principalmente aos teores dos ácidos sulfúrico, nítrico, carboxilícos e outros em menor concentração. Esses poluentes têm como principais precursores os óxidos de nitrogênio e de enxofre, hidrocarbonetos e compostos com grupo carbonila, podendo ser formados tanto em reações na fase gasosa quanto na fase heterogênea da atmosfera.

Estudos tem demonstrado que em muitas partes do mundo uma expressiva alteração da composição atmosférica ocorre devido às contribuições antrópicas, causando danos à saúde e ao meio ambiente (Forti et al., 1990 e 1988; Campos et al., 1998; Gatz, 1991; Losno et al., 1991; Galloway et al., 1982; Granat, 1972; Keene et al., 1972).

Em decorrência dos efeitos causados pela deposição ácida, pesquisas são realizadas para melhor compreender os processos de formação dos ácidos na atmosfera, seus precursores, fontes de emissões, bem como as fontes e os processos que envolvam a participação de seus oxidantes.

Como a chuva contribui de forma significativa para a remoção de muitos poluentes da troposfera, sua composição depende diretamente das emissões antrópicas em regiões urbanizadas, das características naturais da região (vegetação, solo, etc) e das condições meteorológicas, tais como, direção do vento, fluxo da chuva, diferenças sazonais, massas de ar continentais e marítimas, etc. Os impactos ambientais ocasionados pela chuva poluída usualmente designada de chuva ácida, são significativos em diversas regiões do planeta, entre as quais, a Região Metropolitana de São Paulo. Comumente, nos estudos que visam a caracterização da precipitação atmosférica, são determinados os ânions ( $\mathrm{SO}_{4}{ }^{2-}, \mathrm{NO}_{3}^{-}, \mathrm{Cl}^{-}$, formiato e acetato) 
por cromatografia de íons (CI), os cátions $\left(\mathrm{Na}^{+}, \mathrm{K}^{+}, \mathrm{Mg}^{2+}, \mathrm{Ca}^{2+} \mathrm{e} \mathrm{NH}_{4}^{+}\right)$por CI ou espectrofotometria de absorção ou de emissão atômica, o pH e a condutividade. A eletroforese capilar (CE) vem surgindo como alternativa mais rápida e econômica para análises de cátions e ânions em água de chuva (Fukushi, 1999).

A oxidação dos óxidos de enxofre e nitrogênio ocorre por reações através de vários oxidantes, entre eles: $\mathrm{H}_{2} \mathrm{O}_{2}, \mathrm{O}_{3}, \mathrm{HO}^{*}, \mathrm{O}_{2}$, etc. Dos vários processos de formação de ácidos atmosféricos, em fase aquosa, a oxidação do $\mathrm{SO}_{2}$ dissolvido pelo $\mathrm{H}_{2} \mathrm{O}_{2}$ é considerado o mais significativo, ao menos para amostras ácidas. Desta forma, o peróxido de hidrogênio é um composto importante na acidificação da atmosfera, justificando nos últimos anos um crescente interesse pela sua análise na fase gasosa e líquida da atmosfera (Jackson, 1999; Sauer et al.., 1997).

Atualmente existem diversos métodos para determinação de $\mathrm{H}_{2} \mathrm{O}_{2}$ na fase gasosa da atmosfera, residindo as maiores deficiências na amostragem e no seu interfaceamento com a determinação, de modo a viabilizar análises rápidas, sensíveis, confiáveis e de baixo custo. Cabe ressaltar o método amperométrico em fluxo com eletrodo de platina desenvolvido por Gutz e Klockow (1989) por sua seletividade, rapidez e simplicidade, prescindindo do uso de solventes não aquosos e de rigoroso tamponamento requeridos na determinação de $\mathrm{H}_{2} \mathrm{O}_{2}$ por quimiluminescência. Porém, por utilizar eletrodo sólido apresenta a desvantagem de, com o decorrer do tempo e do número de análises, ocorrer a inativação parcial do eletrodo. Tal desvantagem foi superada com método em fluxo amperométrico com eletrodo de gota pendente de mercúrio, desenvolvido em dissertação de mestrado por Rocha (1999) e aplicado a amostras de água.

Entre os compostos carbonílicos, formaldeído e acetaldeído, são componentes importantes dentre as espécies químicas que fazem parte dos 
poluentes atmosféricos através de emissões diretas e reações fotoquímicas (Carlier et al.., 1986, Anderson et al.., 1996).

O formaldeído é encontrado na fase líquida da atmosfera em concentrações significativas, podendo alterar a acidez da água de chuva por causar a inibição da oxidação de espécies de S(IV) a ácido sulfürico, formando hidroximetanossulfonato na reação com $\mathrm{HSO}_{3}^{-}$e também ser oxidado a ácido fórmico (Kieber et al., 1999; Sakugawa, 1993). Sua fotólise pode ser uma fonte significativa de $\mathrm{H}_{2} \mathrm{O}_{2}$, o qual é o principal oxidante do $\mathrm{HSO}_{3}^{-}$(Kieber et al., 1999).

Diversos métodos para análise de compostos carbonílicos no ar podem ser encontrados na literatura (Vairavamurthy et al., 1992; Jianzhen et al., 1995), sendo que a maioria utiliza amostradores nos quais se passa um fluxo de ar por coluna empacotada com um suporte sólido impregnado com um reagente seletivo para esta classe de compostos. Concluída a coleta, os produtos acumulados são eluídos e analisados por técnicas cromatográficas. Dentre estes métodos, o mais freqüentemente utilizado na determinação de formaldeído na fase gasosa da atmosfera é o que combina a coleta em cartuchos contendo sílica gel modificada com 2,4-dinitrofenilhidrazina (DNPH) ou sílica gel recoberta de $\mathrm{C}_{18}$ e DNPH, com a determinação por cromatografia a líquido de alto desempenho (HPLC) (Kiba et al., 1999; Pires, 1998). Apesar de ser aceito e recomendado internacionalmente, este método não é livre de interferências e problemas operacionais. Na presença de $\mathrm{O}_{3}$, há possibilidade de formação de artefatos nos cartuchos impregnados com DNPH, sejam eles de sílica gel, sejam de sílica gel e $\mathrm{C}_{18}$ (Arents et al., 1989; Pires, 1998. Além disso, a amostragem tem que ser interrompida em períodos de precipitação úmida ou quando a umidade relativa do ar se aproxima da saturação (ponto de orvalho), devido à condensação no interior do cartucho e alta solubilidade das hidrazonas. Outro problema é o da manipulação de 
hidrazinas, uma vez que apresentam potencial carcinogênico, sem falar do uso de volume apreciável de solventes tóxicos como acetonitrila na HPLC.

Os compostos orgânicos também podem contribuir de forma significativa para o aumento de acidez na atmosfera. Dentre os inúmeros compostos orgânicos presentes na atmosfera, os ácidos carboxílicos podem representar aproximadamente $11 \%$ desses compostos presentes no aerossol atmosférico e entre 15 a $35 \%$ da acidez nas águas de chuva (Keene et al., 1984; Souza, 1998). Dentre os ácidos carboxílicos, os ácidos fórmico e acético são os mais abundantes, tanto na fase gasosa quanto na fase aquosa da atmosfera. Diversos métodos para análise de compostos carboxílicos na atmosfera encontram-se descritos na literatura que, em sua maioria, utilizam coletores como "impingers", filtros de fibras ou denuders impregnados com soluções alcalinas e determinação por cromatografia de íons (CD), cromatografia a líquido de alto desempenho (HPLC) e cromatografia a gás (CG), após derivatização.

Um poluente gerado principalmente por emissões biogênicas é amônia, único gás alcalino presente na atmosfera em concentraçôes significativas e que pode conduzir à neutralização dos ácidos supra-citados formando sais de amônio como $\left(\mathrm{NH}_{4}\right) \mathrm{HSO}_{4},\left(\mathrm{NH}_{4}\right)_{2} \mathrm{SO}_{4}, \mathrm{NH}_{4} \mathrm{NO}_{3}$ e $\mathrm{NH}_{4} \mathrm{RCOO}$ com formação de aerossóis (Perrino et al., 1999). Assim, a presença de amônia na atmosfera contribui para diminuição da acidez e em regiões onde suas emissões são acentuadas, podem ocorrer precipitações alcalinas. Também, os métodos de coleta para amônia utilizam tubos de difusão, "impingers" ou filtros, impregnados com soluções ácidas e determinação por $\mathrm{CI}$, colorimetria e eletrodo de íon seletivo.

Na região metropolitana de São Paulo, um número ainda pequeno de trabalhos tem enfocado esses aspectos, em combinação ou não com o desenvolvimento de instrumentação para coleta de amostras ambientais (Forti 
et al.., 1990; Fornaro, 1991; Massambani et al.,1994; Martins, 1996; Gutz et al.., 1989; Galvão, 1996; Souza et al., 1997; Rocha, 1999).

Devido à complexidade dos processos que promovem a acidificação, responsáveis por danos à saúde e ao meio ambiente, bem como aos materiais, e também à pressão exercida pela sociedade no combate a poluição, a química analítica tem papel decisivo na elaboração de métodos confiáveis para a determinação e a quantificação de espécies químicas poluidoras.

Assim, desenvolver métodos alternativos de amostragem e determinação analítica que possibilitem melhorar seletividade, a sensibilidade e a eficiência, simplificar a construção e manuseio, reduzir os custo permitir medições "on-line" de espécies químicas para as quais ainda não haja soluções ótimas na literatura ou em equipamentos comerciais, constitui importante contribuição para que se possa investigar de forma ampla as questões que envolvam a qualidade do ar e propor estratégias no controle da poluição.

\subsection{OBJETIVOS}

Como se verá nas revisões bibliográficas introdutórias de vários capítulo, ainda há deficiência de métodos de amostragem para a fase gasosa que possam ser aplicados a várias espécies e que permitam operações prolongadas com boas resoluções.

O primeiro objetivo foi desenvolver metodologias alternativas como coletores difusionais baseados em membranas microporosas (tubos capilares 
de polipropileno) que possibilitem a coleta das espécies químicas citadas durante longos períodos e com resolução de uma amostra por hora ou melhor.

Outro objetivo foi investigar a potencialidade da técnica eletroforese capilar em solução livre com deteç̧ão condutométrica sem contato na determinação de espécies químicas relacionadas com a acidificação da atmosfera tais como formaldeído, ácidos carboxílicos de baixo peso molecular (ácidos fórmico e acético) e amônia na fase líquida e gasosa - em combinação com o primeiro objetivo, assim como de cátions e ânions majoritários na fase líquida em amostras de chuva recolhidas com coletor automático já operante no laboratório.

Em recente dissertação de mestrado (Rocha, 1999), desenvolveu-se novos métodos analíticos em fluxo para determinação de $\mathrm{H}_{2} \mathrm{O}_{2}, \mathrm{HSO}_{3}^{-}$e hidroximetanossulfonato (HMS) na fase líquida da atmosfera. A extensão da aplicação desses métodos à determinação de $\mathrm{H}_{2} \mathrm{O}_{2}$ na fase gasosa da atmosfera constituiu um terceiro objetivo, dependente do primeiro, implicando em desenvolver e comparar dispositivos simples e eficientes de amostragem, tais como coletores difusionais explorando as já citadas membranas microporosas e coletores criogênicos.

Como objetivo secundário, verificar a aplicabilidade das metodologias acima a outros tipos de amostras complexas, tais como:

- espécies de S(IV) em vinho a partir de metodologia desenvolvida para análise de $\mathrm{HSO}_{3}{ }^{-}$em água de chuva.

- peróxido de hidrogênio como subproduto no tratamento de efluentes por radiação ionizante. 
CAPÍTULO III - DESENVOLVIMENTO DE MÉTODOS PARA COLETA DE ESPÉCIES QUÍMICAS DE RELEVÂNCIA AMBIENTAL NA FASE GASOSA DA ATMOSFERA 
A determinação analítica de espécies químicas que compõe a atmosfera enfrenta grandes desafios para alcançar seus objetivos. Entre eles, podemos citar os baixos níveis de concentração de algumas espécies, variações de concentração em função dos locais e horários de amostragem, sazonalidade e as diferenças de temperaturas e umidade.

Idealmente, as medições de espécies químicas na atmosfera deveriam dispensar o uso de amostradores ou pré-concentradores, possiblitando monitoramento contínuo, mas poucas técnicas e métodos o permitem. Porém, quando as técnicas analíticas não alcançam a sensibilidade requerida para a determinação direta de espécies gasosas de interesse na atmosfera, ou quando os equipamentos não são adequados à operação em campo, não podem prescindir de aparatos de coleta com pré-concentração.

As características e eficiência dos pré-concentradores estão diretamente ligadas às das técnicas analíticas empregadas na determinação da espécie química. De forma geral, um aparato de pré-concentração deve possibilitar uma amostragem que permita uma visão real das variações da concentração da espécie ao longo do tempo, ou seja, possuir curto tempo de amostragem, necessitar de pequeno volume de amostra de ar, ser de fácil manuseio, adaptável ao trabalho de campo, seletivo e de baixo custo operacional.

Usualmente, os amostradores se baseiam na sorção das espécies-traço em soluções absorventes contidas em borbulhadores ("impingers") ou em sorventes sólidos, impregnados ("denuders") ou não com reagentes derivatizantes. Ainda, utilizando-se amostradores mantidos em baixas temperaturas, a crioamostragem pode ser uma alternativa vantajosa na coleta de espécies gasosas da atmosfera.

Neste capítulo, serão descritas as metodologias desenvolvidas para coleta de algumas espécies gasosas que participam dos processos de acidificação da atmosfera. Para tanto, desenvolveu-se um coletor por difusão 
empregando-se tubos capilares porosos de polipropileno para amostragem de formaldeído, ácidos orgânicos de baixo peso molecular (ácidos fórmico e acético), amônia e peróxido de hidrogênio e um coletor criogênico passivo, de simples construção, para coleta de peróxido de hidrogênio.

Nos capítulos seguintes serão apresentados os novos métodos desenvolvidos para a coleta e determinação analítica para cada uma das espécies químicas acima citadas.

\subsection{DESENVOLVIMENTO DE COLETOR POR DIFUSÃO ATRAVÉS DE TUBOS CAPILARES POROSOS DE POLIPROPILENO}

Os tubos capilares microporosos de polipropileno (também chamados de filamentos) foram utilizados pela primeira vez em 1990 como trocadores gasosos em pulmões artificiais utilizados durante cirurgias (MEMBRANA, 1990; Lund et al., 2002). Os filamentos mais difundidos são os fabricados pela Akzo Nobel, sob a marca Oxyphan". O Oxyphan ${ }^{(\mathrm{k})}$ é um tubo de boa resistência mecânica, com diâmetro médio de $387 \mu \mathrm{m}$ e que apresenta alta densidade de poros muito finos $(\sim 0,2 \mu \mathrm{m})$ distribuidos uniformemente em suas paredes o que lhe proporcionou excelente desempenho no propósito pretendido na área médica. Apesar de haver alusão ao uso de membranas de polipropileno ou de Teflon ${ }^{\circledR}$ para propósitos de amostragem gasosa em trabalhos da literatura (Liyuan e Dasgupta, 1992), não existe referência alguma ao uso do Oxyphan ${ }^{\mathbb{R}}$. Dadas as características favoráveis deste material, receberá atenção nesta tese no desenvolvimento de um eficiente amostrador de espécies gasosas solúveis, constituído de um feixe de tubos 
capilares com paredes microporosas, percolados por solução absorvente adequada à(s) espécie(s) em pauta, após sua difusão através dos poros da membrana hidrófoba $\left(\mathrm{Oxyphan}^{\mathrm{B}}\right)$. Como este dispositivo foi utilizado para várias espécies, será brevemente descrito a seguir, ficando os detalhes $\mathrm{e}$ particularidades para os capítulos respectivos.

O sistema de coleta de amostras desenvolvido consiste em um tubo de Teflon $^{\text {(8) }}$ de $1,5 \mathrm{~m}$ de comprimento e $5 \mathrm{~mm}$ de diâmetro, dentro do qual foi introduzido um feixe de 12 tubos capilares porosos de polipropileno, como mostra a Figura 3.1.1.

Para formar o feixe, os 12 tubos ocos de polipropileno são unidos com cola de silicone aplicada em pequena extensão nas suas extremidades. A extremidade de entrada do feixe de capilares é alimentada com água deionizada ou solução coletora, impulsionada por bomba peristáltica, sob vazão adequada para cada metodologia de coleta desenvolvida. $O$ volume interno do feixe é da ordem de $0,9 \mathrm{~mL}$.

O tubo externo de Teflon ${ }^{(\mathbb{B})}$ é percorrido, em contra-fluxo, pelo ar a ser amostrado, possibilitando a difusão das espécies químicas da atmosfera para o fluxo coletor. O fluxo de ar foi mantido por aspiração com uma bomba de ar de membrana, do tipo usado para ventilar aquários, com conexão extra para aproveitar a entrada de ar aspirado.

Cabe ressaltar que os microporos do tubo de difusão gasosa filtram aproximadamente $50 \%$ do material particulado fino (diâmetro $<2 \mu \mathrm{m}$ ) e praticamente todo material particulado grosso (Finlayson-Pitts e Pitts, 1986); reduzindo drasticamente a interferência do material particulado no processo de amostragem.

O coletor por difusão foi desenvolvido para amostragem das seguintes espécies gasosas: $\mathrm{CH}_{2} \mathrm{O}$, ácidos orgânicos (fórmico e acético), $\mathrm{H}_{2} \mathrm{O}_{2}$ e $\mathrm{NH}_{3}$. 
Todas as amostras consideradas ao longo da tese foram coletadas no Instituto de Química-USP Bloco 12 superior, em uma sala adaptada para amostragem de espécies químicas nas fases gasosa e líquida da atmosfera.

Dependendo da espécie química coletada, a amostra era tratada e analisada por técnica de eletrofororese capilar ou sistema FIA amperométrico com eletrodo de gota pendente de mercúrio, através de metodologias desenvolvidas neste trabalho, as quais serão apresentadas nos capítulos seguintes.

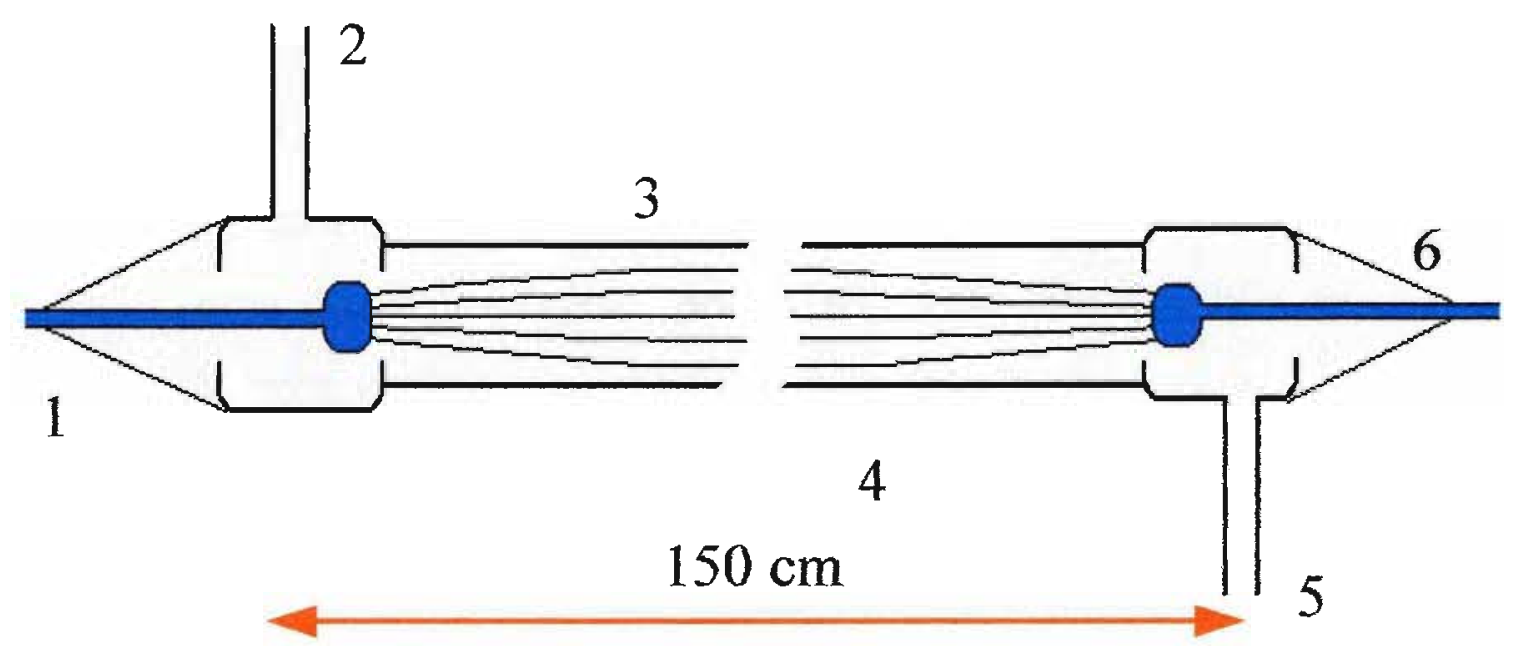

Figura 3.1.1 Coletor por difusão 1- Saída do fluxo coletor de amostras para conexão com o injetor; 2- Entrada do ar aspirado; 3- Tubo de Teflon ${ }^{\circledR}$ (150 $\mathrm{cm}$, diâmetro de $5 \mathrm{~mm}$ ); 4- Tubos porosos ocos de polipropileno (Oxyphan ${ }^{\text {Q }}$ ) com $387 \mu \mathrm{m}$ de diâmetro externo e poros de $0,2 \mu \mathrm{m}$; 5- Saída de Ar; 6Entrada do fluxo coletor de amostras. 


\subsection{DESENVOLVIMENTO DE CRIOAMOSTRADOR PARA $\mathrm{H}_{2} \mathrm{O}_{2}$}

A coleta de peróxido de hidrogênio em fase aquosa pode ser susceptível à interferência de outras espécies presentes na atmosfera como $\mathrm{SO}_{2}$ (levando ao consumo de parte do peróxido) ou do $\mathrm{O}_{3}$ (que poderia aumentar sua concentração). Estudos comparativos entre diferentes métodos, como por exemplo, os efetuados por Staffelbach et al. (1995), que envolvem a coleta em fase líquida por difusão com a coleta criogênica, e estudos efetuados por Campos et al. (1996), que comparam a coleta criogênica em diferentes temperaturas, auxiliam na discriminação dos problemas de interferência.

A amostragem criogênica de $\mathrm{H}_{2} \mathrm{O}_{2}$, na forma em que foi introduzida por Jacob et al. (1986) é tida como um dos métodos menos vulneráveis a interferências. $\mathrm{O}$ método se baseia no fato experimental de que a razão $\mathrm{H}_{2} \mathrm{O}$ : $\mathrm{H}_{2} \mathrm{O}_{2}$ da fase gasosa se mantém praticamente inalterada na fase sólida (gelo coletado), uma grande vantagem, pois a coleta da umidade não precisa ser quantitativa, nem tampouco, conhecida a vazão do ar, bastando dispor da umidade relativa e da temperatura para efetuar os cálculos de concentração na fase gasosa a partir da análise da amostra criogênica descongelada. $O$ equipamento proposto envolve unidade de refrigeração especial para baixas temperaturas com volumoso compressor e condensador alimentando o evaporador, bem como uma bomba de vácuo.

Uma versão simplificada do crioamostrador, utilizando unidade de refrigeração aproveitada de balcões frigorificos comerciais e prescindindo de bomba de vácuo, substituída por ventilador, foi desenvolvida por Gutz et al. (1989). 
Nesta tese, desenvolveu-se um dispositivo de crioamostragem ainda mais simples, de funcionamento "passivo", baixo custo, fácil manipulação e apropriado para coletas em campo, por não depender de energia elétrica.

O crioamostrador consiste de um tubo cilíndrico de alumínio revestido de um fino filme de resina epóxi, com $8,7 \mathrm{~cm}$ de diâmetro e $16,2 \mathrm{~cm}$ de altura, fechado num dos lados, montado com a abertura voltada para cima. O tubo é preenchido com gelo seco e fechado com uma tampa de espuma de poliuretano, provida de duto de escape de $\mathrm{CO}_{2}$. Este dispositivo é apoiado sobre um tubo de PVC de diâmetro similar, com $30 \mathrm{~cm}$ de altura e montado concentricamente dentro de um segundo tubo de PVC com $15 \mathrm{~cm}$ de diâmetro e $60 \mathrm{~cm}$ de altura, apoiado em 3 pés de $10 \mathrm{~cm}$ de altura. Uma tampa com 27 $\mathrm{cm}$ de diâmetro, suspensa $3 \mathrm{~cm}$ acima do conjunto, evita a entrada de material particulado grosso (Figura 3.2.1).

A superficie externa do cilindro opera em temperatura próxima de $-70^{\circ} \mathrm{C}$, fazendo com que a umidade do ar congele em sua superficie. $\mathrm{O}$ esfriamento do ar provoca aumento da sua densidade, ocasionando um movimento de ar descendente. Desta forma, não há necessidade de dispositivos elétricos para promover a refrigeração ou a circulação de ar.

A amostra congelada é raspada periodicamente da superficie do cilindro de alumínio e acondicionada em frascos plásticos e preservada em "freezer" a $-15^{\circ} \mathrm{C}$, para serem analisadas em momento oportuno por sistema em fluxo com detecção amperométrica em eletrodo de gota pendente de mercúrio, que será descrito posteriormente. 


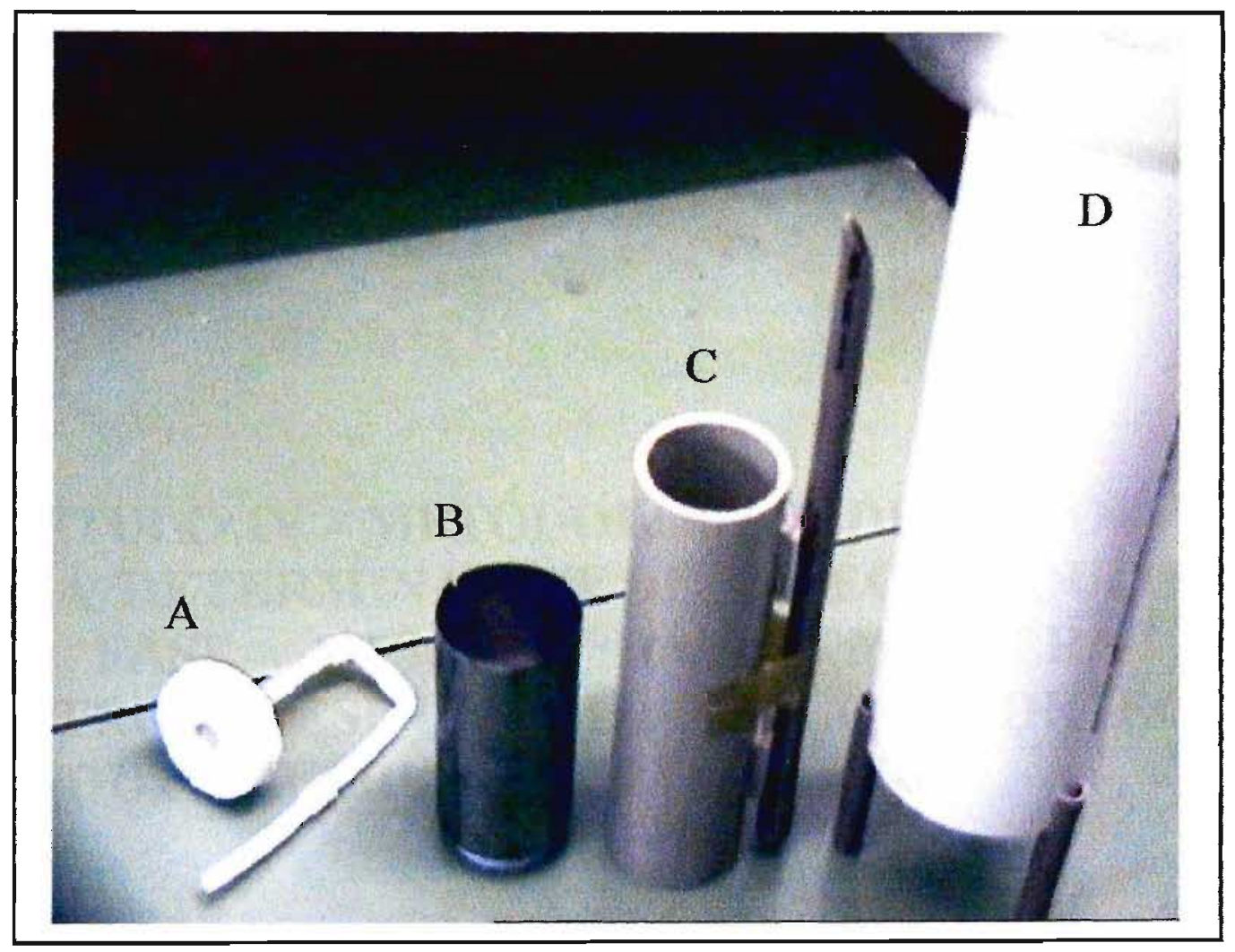

Figura 3.2.1 - Crioamostrador: A - Tampa de espuma de poliuretano provida de duto de escape de $\mathrm{CO}_{2} ; \mathrm{B}$ - Tubo cilíndrico de alumínio revestido de filme de resina epóxi; C- Tubo de PVC com $30 \mathrm{~cm}$ de altura; D- Tubo de PVC com $15 \mathrm{~cm}$ de diâmetro e $60 \mathrm{~cm}$ de altura. 
CAPÍTULO IV - METODOLOGIAS DESENVOLVIDAS PARA DETERMINAÇÃO DE ESPÉCIES QUÍMICAS NA FASE GASOSA DA ATMOSFERA POR ELETROFORESE CAPILAR COM DETECTOR CONDUTOMÉTRICO SEM CONTATO 


\subsection{METODOLOGIA DESENVOLVIDA PARA DETERMI- NAÇÃO DE FORMALDÉ́DO E ÁCIDOS FÓRMICO E ACETICO POR ELETROFORESE CAPILAR COM DETECTOR CONDUTOMÉTRICO SEM CONTATO}

Vários métodos para análise de compostos carbonilicos e carboxílicos no ar podem ser encontrados na literatura (Vairavamurthy et al., 1992; Sollinger et al., 1992; Jianzhen et al., 1995; Chao-Jung et al., 1998; Zervas et al., 1999), sendo que a maioria utiliza amostradores impregnados com soluções reativas. Desta forma, os produtos gerados, a partir da reação dos compostos carbonílicos e carboxílicos com soluções reativas, são eluídos e analisados por técnicas cromatográficas.

\subsubsection{CONSIDERAÇÕES GERAIS SOBRE FORMALDEÍDO}

Dentre os compostos com grupo carbonila, os mais abundantes na atmosfera são formaldeído, acetaldeído e acetona. O formaldeído participa de várias reações, tanto na fase gasosa quanto na fase aquosa da atmosfera; na temperatura ambiente o formaldeído é um gás incolor, de alta volatilidade e reatividade, extremamente solúvel em água.

Compostos carbonílicos, particularmente aldeídos são tóxicos, provocando irritação nos olhos e nos pulmões (Zhang et al., 1994). Formaldeído e acroleína são suspeitos de serem agentes carcinogênicos e alguns dos compostos secundários formados por aldeídos, especialmente nitratos de peroxiacetila (PAN) e ozônio, são muito nocivos (Carlier et al. , 1986; Dodge, 2000). 
Entre os compostos carbonílicos, formaldeído e acetaldeído, são componentes importantes dentre as espécies químicas que fazem parte dos poluentes atmosféricos gerados fotoquimicamente. $\mathrm{Na}$ literatura, pode-se encontrar vários artigos de revisão sobre os mecanismos através dos quais o formaldeído e acetaldeído são formados na atmosfera (Anderson et al., 1996; Altshuller, 1993; Atkinson, 2000).

Atribui-se a presença de compostos carbonílicos na atmosfera a duas formas de emissão: primária (emissão direta por atividade antrópica ou natural) e secundária (reações fotoquímicas). As fontes naturais de compostos carbonílicos de menor impacto são as emissões biogênicas de plantas e de alguns insetos, sendo a emissão feita por excremento de animais e queimadas as de maior importância. Como fontes antrópicas de compostos carbonílicos temos vários tipos de atividades industriais (petroquímica, plásticos, tintas e vernizes, etc.) e por veículos automotores (Larsen, et al., 1998). De forma geral, todos os compostos orgânicos que são emitidos para a atmosfera podem ser fontes de compostos carbonílicos através de reações fotoquímicas.

A Lei de Henry é usada para descrever o equilíbrio de solubilidade de gases na fase aquosa:

$$
[\mathrm{x}]=\mathrm{K}_{\mathrm{x}} \cdot \mathrm{P}_{\mathrm{x}}
$$

onde, $[\mathrm{x}]$ é a concentração em equilíbrio de $\mathrm{x}$ na fase aquosa.

$\mathrm{P}_{\mathrm{x}}$ é a pressão parcial de $\mathrm{x}$ na fase gasosa.

$\mathrm{K}_{\mathrm{x}}$ é a constante da Lei de Henry em mol L ${ }^{-1} \mathrm{~atm}^{-1}$

Gases com $\mathrm{K}_{\mathrm{x}}>1000$ são muito solúveis e geralmente são concentrados em fase aquosa, alcançando concentrações relativas muito superiores às que teriam se permanecessem em fase gasosa.

Devido à sua alta solubilidade (Tabela 4.1.1.1) o formaldeído é encontrado na fase líquida da atmosfera em concentrações significativas, podendo alterar a acidez da água de chuva por causar a inibição da oxidação 
de espécies de S(IV) a ácido sulfúrico, formando hidroximetanossulfonato na reação com $\mathrm{HSO}_{3}^{-}$, em pH adequado, e também ser oxidado a ácido fórmico (Kieber et al., 1999; Sakugawa, 1993). Por outro lado, sua fotólise pode ser uma fonte significativa de $\mathrm{H}_{2} \mathrm{O}_{2}$, o qual é o principal oxidante do $\mathrm{HSO}_{3}{ }^{-}$(em pH 4 a 7) a ácido sulfúrico (Kieber et al., 1999).

A deposição úmida do $\mathrm{CH}_{2} \mathrm{O}$ (mesmo sem reagir) é um eficiente processo de remoção, podendo sua concentração na água de chuva ser aproximadamente três ordens de grandeza maior do que nas águas superficiais (Thompson, 1980; Kieber et al., 1990). 
Tabela 4.1.1.1 Valores das constantes de Henry, para alguns compostos, a $25^{\circ} \mathrm{C}$.

\begin{tabular}{|c|c|}
\hline Composto & $\begin{array}{l}\text { Constante de Henry } \\
\left(\mathrm{mol} . \mathrm{L}^{-1} \cdot \mathrm{atm}^{-1}\right)\end{array}$ \\
\hline Dióxido de Enxofre & 1,24 \\
\hline Dióxido de Nitrogênio & $1,2 \times 10^{-2}$ \\
\hline Ozônio & $1,1 \times 10^{-2}$ \\
\hline Peróxido de Hidrogênio & $7 \times 10^{4}$ \\
\hline Peroxiacetilnitrato & 3,6 \\
\hline Acetaldeído & 15 \\
\hline Formaldeído & $6 \times 10^{3}$ \\
\hline Ácido Peracético & 480 \\
\hline Metilhidroperóxido & 220 \\
\hline Radical HO* & 2,5 \\
\hline Radical $\mathrm{HO}_{2} *$ & $2 \times 10^{3}$ \\
\hline $\mathrm{O}_{2}$ & $1,3 \times 10^{-3}$ \\
\hline Ácido Fórmico & $5,53 \times 10^{3}$ \\
\hline Ácido Acético & $5,50 \times 10^{3}$ \\
\hline Ácido Propiônico & $5,71 \times 10^{3}$ \\
\hline Ácido Butírico & $4,72 \times 10^{3}$ \\
\hline $\mathrm{NH}_{3}$ & 62 \\
\hline $\mathrm{HCl}$ & $2,5 \times 10^{3}$ \\
\hline $\mathrm{HNO}_{3}$ & $2,1 \times 10^{5}$ \\
\hline
\end{tabular}


Devido a sua toxicidade e ao papel de destaque que o formaldeído apresenta na química da atmosfera, uma grande variedade de métodos foi desenvolvida para sua determinação na fase gasosa, conforme retratam excelentes trabalhos de revisão (Vairavamurthy et al., 1992; Parrish et al., 2000).

Dentre as técnicas espectroscópicas, cabe destacar as que permitem medições "in situ", tais como: espectroscopia de absorção por diodo laser de tunelamento (Harris et al., 1989; Fried et al., 1997), espectroscopia de fluorescência induzida por laser (Becker et al., 1975; Möhlmanm, 1985), entre outras. Essas técnicas são seletivas, não destrutivas e quantitativas. Porém, requerem longos caminhos ópticos e instrumentação complexa de alto custo.

Tradicionalmente, as técnicas colorimétricas são simples e populares e foram estabelecidas há muito tempo, como os métodos do ácido cromotrópico e da pararosanilina. $\mathrm{O}$ método de ácido cromotrópico baseia-se na formação de uma cor violeta por reação entre formaldeido e ácido 4,5 dihidroxinaftaleno-2,7 dissulfônico e a amostragem é feita por "impinger" contendo solução reagente, solução de bissulfito ou água (Altshuller et al., 1961), residindo seu maior problema na sensibilidade, requerendo longo tempo de amostragem. Por outro lado, o método da pararosanilina apresenta interferentes como acetaldeído, acroleinas e outros capazes de reagir com $\mathrm{HSO}_{3}{ }^{-}$formando adutos, vez que este método utiliza reações entre pararosanilina, bissulfito e formaldeído (Ryles et al., 1965). As condições podem ser adaptadas para permitir ou a determinação de formaldeído ou de $\mathrm{SO}_{2}$ atmosférico, aceito como método oficial, apesar dos seus conhecidos problemas, que dão ensejo a novos aperfeiçoamentos Dasgupta et al. (1980).

Técnicas que utilizam deteç̧ão por fluorescência para formaldeído apresentam boa seletividade e se servem de reações bastante específicas como 
é o caso do método que envolve a reação de Hanztch, que ocorre entre acetilacetona, amônia e formaldeído, formando o produto 3,5 diacetyl $-1,4$ dihidrolutidina. Essa reação foi introduzida por Nasch (1953), em um método colorimétrico para formaldeído (Zurek et al., 1999; Reche et al., 2000).

Atualmente, para determinação de $\mathrm{CH}_{2} \mathrm{O}$ em amostras líquidas ou de ar, um monitor comercial foi desenvolvido utilizando a reação de Hanztch, atingindo limites de detecção em torno de $2 \mathrm{nmol} \mathrm{L}^{-1}$ na fase gasosa (Aero Laser GmbH, 2002).

Também seletiva é a técnica com deteç̧ão por fluorescência com derivatização por reações catalisadas por enzimas. Na determinação de formaldeído a enzima formaldeído-dehydrogenase catalisa a reação entre formaldeído e adeninas nucleotídeo beta-nicotinamida (Heikes et al., 1996). Todavia, a conservação das enzimas é, via de regra, um problema, especialmente em trabalhos de campo.

Segundo Parrish et al. (2000), várias intercomparações dessas técnicas tem sido relatadas, como por exemplo: Klenidienst et al. (1988) comparou algumas técnicas (fluorescência enzimática, espectroscopia de absorção com diodo-laser e técnicas utilizando DNPH como agente derivatizante), amostrando $\mathrm{CH}_{2} \mathrm{O}$ em área rural, encontrando concentrações entre 1 a 10 ppbv (partes por bilhão em volume) e boa correlação entre as técnicas; Lawson et al (1990) avaliou técnicas com deteç̧ão de fluorescência, fluorescência enzimática e com derivatização DNPH em área urbana, obtendo valores de concentrações entre 4 a 20 ppbv, onde diferenças de resultados entre algumas técnicas chegaram a $25 \%$.

$\mathrm{Na}$ década de 70 as técnicas cromatográficas, em conjunto com métodos derivatizantes, passaram a ser largamente utilizadas na detecção de compostos carbonílicos no ar. 
Dentre essas, a técnica mais popular é a cromatografia a líquido de alto desempenho (HPLC) com detecção por absorção no ultravioleta com préconcentração através de reações de derivatização com 2,4 - dinitrofenilhidrazina (DNPH).

A coleta na fase gasosa da atmosfera é uma etapa crucial na determinação de espécies químicas, interferindo principalmente na sensibilidade, mas também na seletividade da metodologia utilizada.

Um método interessante para amostragem de ar é a coleta criogênica, baseada no princípio que espécies solúveis são solidificadas juntamente com o vapor de água. Segundo Vairavamurthy et al. (1992), a crioamostragem seguida de derivatização com DNPH para deteç̧ão de formaldeído foi usada por Neitzert et al. (1981), o qual utilizou um tubo de vidro resfriado com nitrogênio líquido sob vazão de ar de $1 \mathrm{~L} \mathrm{~min}^{-1}$ com posterior análise por HPLC.

O uso de derivatização com DNPH para coleta de compostos carbonílicos estende-se a coletores como "impingers", sorventes sólidos e tubos de difusão.

A primeira aplicação com "microimpinger" para determinação de compostos carbonílicos com DNPH e detecção por HPLC foi o método desenvolvido por Kuwata et al. (1979) (appud Vairavamurth et al. 1992).

Na coleta com "impinger" pode ocorrer evaporação da solução coletada submetida a fluxos altos de ar ou longos períodos de amostragem. Essa desvantagem pode ser contornada usando-se sorventes sólidos, além de apresentar maior sensibilidade do que os "impingers" (Vairavamurth et al. 1992; Schlitt, H., 1997).

Sorventes sólidos geralmente são impregnados com DNPH, encontrados comercialmente como filtros de fibra de vidro, sílica gel SepPack, Florisil, Carbopack e $\mathrm{C}_{18}$. 
Cartuchos de sílica gel impregnados com DNPH foram inicialmente empregados por Beasley et al. (1980). Posteriormente, Arnts et al. (1989) demonstraram a interferência negativa causada por $\mathrm{O}_{3}$ em coletas com cartuchos de sílica gel (Vairavamurth et al. 1992).

Cartuchos de $\mathrm{C}_{18}$ (octadecilsilano-silica) com características apolares e hidrofóbicas (sílica gel e Florisil são hidrófilos), foram introduzidos por Kuwata et al. (1983) para determinação de compostos carbonílicos com DNPH.

Lipari et al. (1985) utilizaram Cartuchos de Florisil (silicato de magnésio), produzido pela Floridian Company, para determinar formaldeído em ar e exaustão de veículos.

Esses métodos que utilizam sorção em sorventes sólidos necessitam do uso de filtros para retenção do material particulado. O uso de filtros pode acarretar reações ou evaporação de espécies presentes no material particulado retido, principalmente em dias com temperaturas elevadas.

Para contornar o problema, pode-se recorrer ao uso de tubos de difusão impregnados com soluções derivatizantes ("denuders").

De forma resumida os tubos de difusão ("diffusion denuders") consistem em tubos com paredes impregnadas por solução absorvente que são percorridos por fluxo de ar. Devido ao elevado coeficiente de difusão dos gases e tendo o material particulado um coeficiente de difusão de aproximadamente $10^{-4} \mathrm{em}$ relação aos gases, o material particulado atravessa o tubo enquanto os gases alcançam as paredes do tubo, na qual são coletados posteriormente eluídos com solvente adequado. Atualmente, os "denuders" são amplamente empregados na determinação de formaldeído na fase gasosa.

Outra alternativa é uso de coletores que empregam membranas porosas em sistemas em fluxo ("diffusion scrubbers"). Dentre estes, Dasgupta et al. $(1988,1990)$ utilizaram a reação de Hantzch para determinação de $\mathrm{CH}_{2} \mathrm{O}$ na 
fase gasosa com detecção por fluorescência e para coleta, desenvolveram um sistema em fluxo com membrana hidrofóbica microporosa. No sistema, a solução aquosa coletada fluía por dentro de um único tubo de membrana de

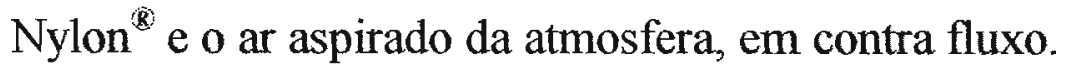

Liyuan e Dasgupta (1992), desenvolveram amostradores similinares ao descrito resumidamente acima, porém utilizando membranas de polipropileno, silicone e acetato de celulose. Os sistemas de coleta foram utilizados para determinação de $\mathrm{HNO}_{2}, \mathrm{HNO}_{3}, \mathrm{HCl}$ e $\mathrm{HCOOH}$ na atmosfera e outras matrizes, utilizando eletroforese capilar (CE) com detector de UV-Vis.

Cabe ressaltar, que na década de 90 a CE começa a emergir como uma técnica de separação para multianálises em estudos que envolvem a química analítica ambiental.

Ainda, aparatos alternativos que não utilizam membranas foram desenvolvidos e aplicados com sucesso à determinação de formaldeído na fase gasosa.

Lazrus et al. (1988) desenvolveram um sistema de amostragem que baseia-se na alta solubilidade de formaldeído em água. Neste sistema, os fluxos de água (coletora) e de amostra de ar percorrem um tubo de vidro espiralado no mesmo sentido ("diffusion scubber coil"). Posteriormente, a solução aquosa de formaldeído é misturada "on-line" com $\mathrm{NAD}^{+}$e injetado em um fluorímetro. A eficiência da coleta foi determinada em aproximadamente $95 \%$.

Outro método baseado na alta solubilidade do $\mathrm{CH}_{2} \mathrm{O}$ em água foi desenvolvido por Fan e Dasgupta (1994). O método apresenta grande sensibilidade (ppt) e recorre a reação de 1,3 ciclohexanedone com formaldeído seguido de detecção por fluorescência. Após coleta com sistema que utiliza tubo de membrana hidrofílica de Nafion ${ }^{(\mathbb{B})} 811$ e água como líquido coletor. 
Além dos trabalhos citados, na literatura encontra-se outros tipos de membranas porosas utilizadas para coletas por difusão, como: PTFE (Komazaki et al., 1999), polipropileno (Uchiyama et al., 1999), etc.

Dentre estes métodos, o mais utilizado na determinação de formaldeído na fase gasosa da atmosfera é o que utiliza a coleta em cartuchos contendo sílica gel modificada com 2,4-dinitrofenilhydrazina (DNPH) ou sílica gel recoberta de $\mathrm{C}_{18}$ e DNPH, com a determinação por cromatografia a líquido de alto desempenho (HPLC). Entretanto, este método não é livre de interferências e problemas operacionais, como já enfatizados no Capítulo II (páginas 36/37).

Justifica-se, pois, a investigação de métodos alternativos de coleta e de determinação destes compostos, especialmente o formaldeído. Neste projeto, considerou-se a coleta por absorção em fase líquida contida em tubo capilar poroso, seguida de determinação por $\mathrm{CE}$.

\subsubsection{CONSIDERAÇÕES GERAIS SOBRE OS ÁCIDOS FÓRMICO E ACÉTICO}

Dentre os ácidos carboxílicos, os ácidos fórmico e acético são, via de regra, os mais abundantes, tanto na fase gasosa quanto na fase aquosa da atmosfera. De forma geral, os ácidos carboxílicos presentes na atmosfera são emitidos diretamente por fontes antrópicas e/ou naturais (biogênicas) (Calvert et al., 1983; Puxbaum et al., 1988), sendo que as fontes antrópicas tem sido associadas à emissão dos ácidos acético, fórmico, ceto-ácidos e dicarboxílicos, tais como oxálico, succínico e glutárico e as fontes biogênicas dos ácidos fórmico, acético e ácidos graxos (Talbot et al., 1990; Chebbi et al., 1996). 
A presença destes ácidos na atmosfera pode ser prejudicial à saúde humana, podendo provocar problemas respiratórios e irritações nos olhos.

Desta forma, em regiões com atividades antrópicas acentuadas, torna-se necessário conhecer os níveis de concentração na atmosfera desses ácidos orgânicos, preferencialmente por métodos analíticos que sejam de fácil manejo, baixo custo e possibilitem monitoramento contínuo ou em intervalos curtos de tempo.

$\mathrm{Na}$ literatura, há diversos métodos descritos para a coleta, preservação e determinação de ácidos carboxílicos de baixo peso molecular, discutidos em artigos de revisão (Suzuki, 1999; Dabek-Zlotorzynska et al., 2000).

Por apresentar boa seletividade e sensibilidade a cromatografia de íons com deteç̧ão condutométrica tem sido a técnica mais utilizada para determinação de ácidos orgânicos de baixo peso molecular presentes na atmosfera (Brocco et al., 1986; Bachmann et al., 1989; Morales et al., 1994; Souza, 1997 e 1998).

Para determinação de ácidos carboxílicos de alto e baixo peso molecular em uma única análise, são utilizadas as técnicas da cromatográfia a gás (CG) (Kawamura, 1985; Chao-Jung et al., 1998) e a líquido de alto desempenho (Elbert et al., 1985).

Nas análises efetuadas com CG recorre-se à derivatização dos ácidos carboxílicos para formação de espécies voláteis através de reagentes como: terc-butildimetilsilano, trimetilsilano, diazometano, etc. $\mathrm{O}$ mesmo procedimento de derivatização é exigido em análises de ácidos orgânicos por HPLC.

Recentemente a eletroforese capilar (CE) também vem surgindo como técnica alternativa na determinação de ácidos orgânicos na atmosfera. Alguns trabalhos comparativos entre CE e CI foram realizados nos últimos anos e encontravam-se disponíveis na literatura (Jackson, 1995; Souza et al., 1998). 
Da mesma forma que para os compostos carbonílicos, os processos comumente utilizados para amostragem dos ácidos carboxílicos presentes na atmosfera baseiam-se na sorção destes em solução absorvente ou sorvente sólidos.

Ainda, métodos de análises contínuas, como espectroscopia de infra vermelho por transformata de Fourier (FTIR), podem ser usadas para determinação de ácido fórmico (Grosjean et al., 1990) se bem que a sensiblidade deixa a desejar.

Vários relatos na literatura envolvem coleta com "impingers". Geralmente, são usadas soluções aquosas de $\mathrm{Na}_{2} \mathrm{CO}_{3}, \mathrm{KOH}$ ou simplesmente água deionizada como soluções absorventes nos "impingers" (Lopez et al., 1987; Kawamura et al., 1985; Grönberg et al., 1993; Zervas et al., 1999).

Também, os ácidos orgânicos podem ser coletados com sorventes sólidos do tipo Tenax, carvão ativo e Florisil ou substâncias básicas sólidas como $\mathrm{Ba}(\mathrm{OH})_{2}, \mathrm{Na}_{2} \mathrm{~B}_{4} \mathrm{O}_{7}$, etc.

De forma geral, os sorventes sólidos requerem a extração de espécies de interesse em solventes adequados, acarretando aumento do tempo de análise.

Preferencialmente, são usados tubos de difusão ("denuders") impregnados com soluções alcalinas, por não necessitarem de filtros para remoção do material particulado. Para que os "denuders" sejam eficientes na coleta, devem conter extensa superfície de contato e possuir quantidade suficiente de filme sorvente, distribuída de forma homogênea, o que leva a trabalhos longos, meticulosos e tediosos de preparação.

Trabalhos comparando vários sistemas de coletas com sorventes sólidos são descritos na literatura. Entre eles, Keene et al. (1989), compararam amostradores de cartuchos de resina, tubos de difusão impregnados com $\mathrm{NaOH}$, filtros de fibra de vidro e filtros de $\mathrm{Nylon}^{\circledR}$ impregnados com $\mathrm{NaOH}$ e 
filtro de celulose com $\mathrm{NaOH}$ e $\mathrm{KOH}$, obtendo boa correlação entre eles para coleta de ácidos fórmico e acético com deteç̧ão por cromatografia de íons.

Zervas et al. (1999) compararam a eficiência de coleta entre diferentes métodos de amostragem dos ácidos fórmico e acético em sistema para exaustão de gases. Nesse trabalho, foram comparadas coletas de ácidos orgânicos por dois "impingers" contendo água pura e outro com solução aquosa de $\mathrm{Na}_{2} \mathrm{CO}_{3}$ e quatro sorventes sólidos do tipo: sílica, fluorisil, alumina $\mathrm{B}$ e alumina $\mathrm{N}$. As análises foram feitas por $\mathrm{CI}$ e $\mathrm{CG}$.

A eficiência de eluição nos cartuchos de sorventes sólido foi de $100 \%$ para ácido fórmico em sílica e florisil e de $80-85 \%$ para ácido acético, os outros sorventes não apresentaram boa eficiência de eluição. Já com os "impingers", a eficiência de coleta obtida por Zervas et al. (1999) foi de 90\% para ácidos fórmico e acético no que continha água deionizada e $95 \%$ no abastecido com solução de $\mathrm{Na}_{2} \mathrm{CO}_{3}$. Neste trabalho são citadas referências da literatura atribuindo coleta de até $99 \%$ dos ácidos orgânicos em "impingers" contendo água deionizada.

Alternativamente, a coleta com aparatos que usam membranas porosas foram desenvolvidas para determinação de várias espécies químicas inorgânicas e orgânicas presentes na fase gasosa. Segundo Suzuki (1997), os aparatos com membranas ("diffusion scrubber") menores do que $1 \mathrm{~m}$ de comprimento não apresentaram boa eficiência de coleta. Desta forma, Suzuki (1997) desenvolveu um coletor para ácidos orgânicos na atmosfera, no qual utiliza um tubo de politetrafluoroetileno (PTFE) de $220 \mathrm{~cm}$ de comprimento e $2 \mathrm{~mm}$ de diâmetro externo, encapsulado em um tubo de PTFE de $4 \mathrm{~mm}$ de diâmetro externo, utilizando água deionizada como substância absorvente e detecção por CI. Na metodologia descrita em seu artigo, a eficiência de coleta foi de $97 \%$ para ácido fórmico e $94 \%$ para ácido acético. 


\subsubsection{COLETA DE FORMALDEÍDO E ÁCIDOS FÓRMICO E ACÉTICO NA FASE GASOSA UTILIZANDO-SE COLETOR POR DIFUSÃO COM TUBOS DE POLIPROPILENO}

$\mathrm{Na}$ literatura encontram-se alguns métodos de coleta para aldeídos e ácidos orgânicos de baixo peso molecular baseados em suas altas solubilidades em água, demonstrando excelente eficiência de coleta, já citados anteriormente (Altshuller et al., 1961; Lazsus et al., 1988; Fan e Dasgupta, 1994; Zervas et al., 1999; Suzuki, 1997).

Nesta tese, o método desenvolvido de coleta para formaldeído e os ácidos fórmico e acético baseou-se no mesmo recurso, ou seja, na alta solubilidade dessas espécies (Tabela 4.1.1.1), que possibilitou a coleta em fluxo de água deionizada. O método foi desenvolvido com o uso de tubos porosos ocos de polipropileno (Oxyphan ${ }^{\text {) }}$ ), arranjados num feixe, conforme descrito no capítulo III, através dos quais o fluxo é bombeado, sendo que as espécies citadas acima permeiam por difusão através das paredes do tubo.

Os ácidos orgânicos, fórmico e acético, apresentam pKa em torno de 3,5 e 4,7 respectivamente, ou seja, condições favoráveis para coleta pelo método desenvolvido, pois se encontram predominantemente dissociados acima deste $\mathrm{pH}$.

Cabe repetir que os microporos do tubo de difusão gasosa utilizado no coletor tem diâmetro de $0,2 \mu \mathrm{m}$, atuando como filtros para, pelo menos, $50 \%$ do material particulado fino (diâmetro $<2 \mu \mathrm{m}$ ) e praticamente de todo material particulado grosso (Finlayson-Pitts e Pitts, 1986). Isso não prejudica a coleta de formaldeído vez que, segundo Andrade et al. (1995), mais de 99\% da massa de aldeídos encontrado na atmosfera esta presente na fase gasosa e menos do que $1 \%$ no aerossol. Desta forma, a interferência do material 
particulado na amostragem, utilizando o coletor por difusão, torna-se insignificante.

Para coleta dessas espécies na atmosfera o fluxo coletor de água deionizada foi mantido em $15 \mu \mathrm{L} \min ^{-1}$, impulsionado por bomba peristáltica e a vazão do ar em $345 \mathrm{~mL} \mathrm{~min}^{-1}$, aspirado por bomba comercial utilizada em aquários.

As amostras foram coletadas em frascos (tipo vial), os quais foram devidamente pesados, antes e depois da coleta, para que o volume da amostra pudesse ser determinado por diferença das massas. Posteriormente, as amostras foram tratadas e injetadas em eletroforese capilar. $O$ tratamento da amostra e a nova metodologia desenvolvida para análise em Eletroforese Capilar de Zona (CE) serão descritos a seguir.

\subsubsection{DETERMINÇÃO DE FORMALDEÍdO $\mathrm{E}$ ÁCIDOS FÓRMICO E ACÉTICO POR ELETROFORESE CAPILAR COM DETECÇÃO CONDUTOMÉTRICA SEM CONTATO NA FASE GASOSA DA ATMOSFERA}

Dentre as técnicas utilizadas para a análise de amostras ambientais, a eletroforese capilar vem surgindo como alternativa mais rápida, simples $\mathrm{e}$ econômica (Fukushi et al., 1999).

De forma simplificada, a eletroforese capilar (CE) é uma técnica de separação baseada na mobilidade diferenciada de espécies iônicas ou ionizáveis submetidas à ação de um campo elétrico (Figura 4.1.4.1). As características e os mecanismos da CE são encontrados em excelentes artigos publicados por Tavares (1996 e 1997); bem como, em recente revisão sobre detecção eletroquímica em CE (Fracassi, 2003). 


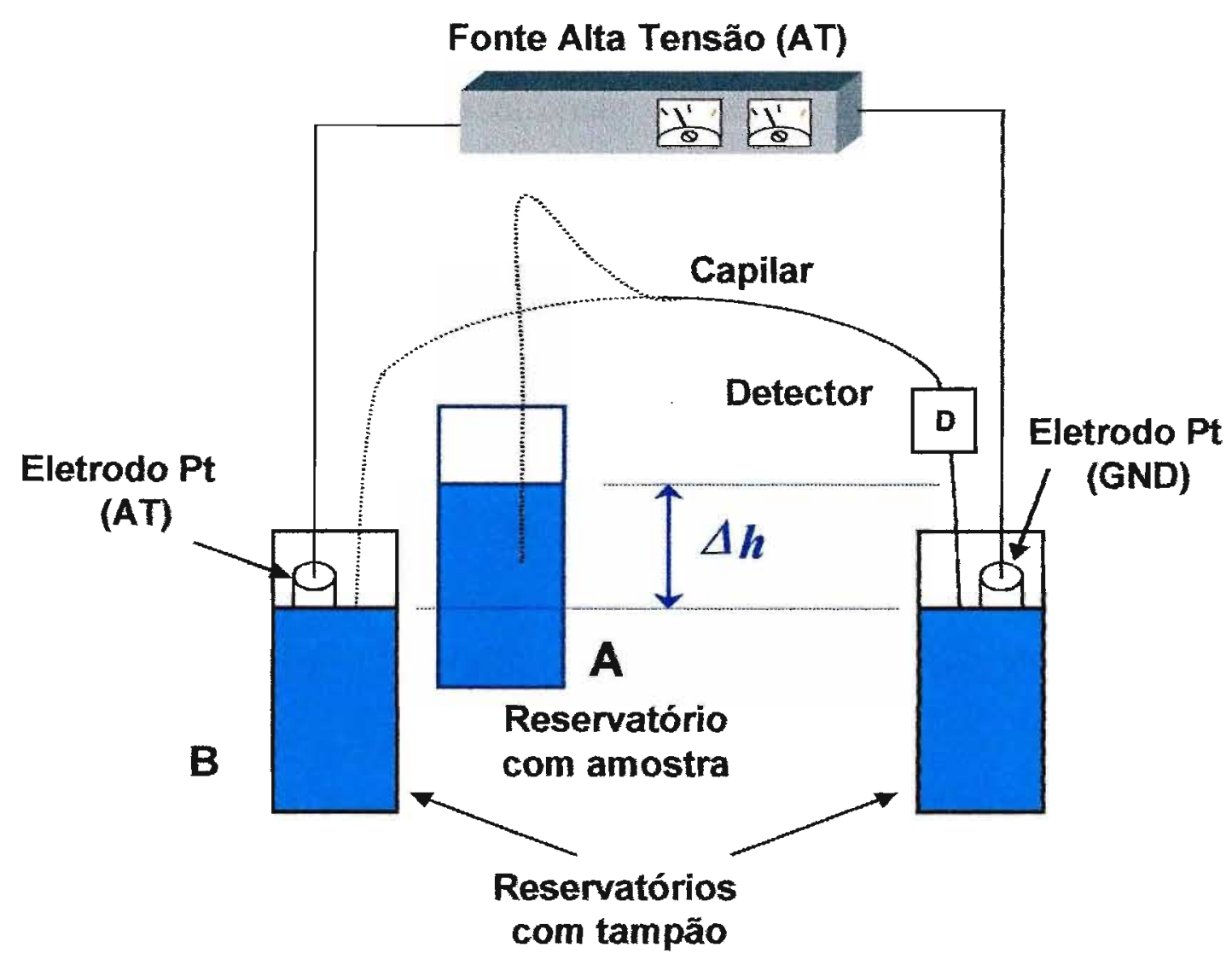

Figura 4.1.4.1 Esquema do sistema de eletroforese capilar. A posição A representa a etapa de introdução hidrodinâmica de amostra (frasco de amostra elevado, fonte desligada). A posição B corresponde à separação eletroforética (frasco de tampão no lugar da amostra, fonte ligada). D corresponde ao detetor condutométrica sem contato com a solução. 
Entretanto, o formaldeído hidratado não apresenta mobilidade eletroforética nem sinal condutométrico adequados à sua separação e determinação por CE. Todavia, a reação entre o formaldeído e o $\mathrm{HSO}_{3}{ }^{-}$ levando à formação de ácido orgânico estável ( Tabela 4.1.4.1) e fortemente ionizado, o hidroximetanossulfonato (HMS), constitui procedimento de derivatização apropriado:

$$
\mathrm{HCHO}+\mathrm{HSO}_{3}^{-} \rightarrow \mathrm{H}_{2} \mathrm{C}(\mathrm{OH}) \mathrm{SO}_{3}^{-}
$$

$\mathrm{Na}$ literatura, como por exemplo, Dasgupta et al. (1980), encontram-se métodos descritos nos quais se utiliza a formação do aduto (HMS) para determinação analítica de formladeído ou de $\mathrm{SO}_{2}$ na fase gasosa da atmosfera. Em trabalho recente, a formação do aduto (HMS), conferindo-lhe mobilidade eletroforética, foi utilizada para determinação de aldeídos em emissões de gases provenientes de escapamento de veículos automotores através de coleta com solução absorvente contendo $\mathrm{HSO}_{3}{ }^{-}$e posterior análise em CE (Pereira et al., 1999).

Porém, a coleta de aldeídos no ar com solução derivatizante de $\mathrm{HSO}_{3}{ }^{-}$ torna-se ineficiente após certo tempo, vez que o excesso de oxigênio acaba oxidando o sulfito a sulfato, que não forma $o$ aduto. 
Tabela 4.1.4.1 - Constantes de Estabilidade de Hidroxialcanosulfonatos (Albuquerque, 1993)

\begin{tabular}{|c|c|c|c|}
\hline Aldeído & Hidroxialquilsulfonato & Estrutura & $\begin{array}{c}{ }^{\mathrm{ap}} \mathrm{K}, \mathrm{mol} / \mathrm{L} \\
\left(25^{\circ} \mathrm{C}\right)\end{array}$ \\
\hline Formaldeído & Hidroximetanosulfonato & $\mathrm{CH}_{2}(\mathrm{OH}) \mathrm{SO}_{3}^{-}$ & $3,6 \times 10^{6}$ \\
\hline Acetaldeído & 1-Hidroxi-1-etano sulfonato & $\mathrm{CH}_{3} \mathrm{CH}(\mathrm{OH}) \mathrm{SO}_{3}^{-}$ & $1,2 \times 10^{5}$ \\
\hline Glioxal & $\begin{array}{l}\text { 1-Hidroxi-2,2-diol- } \\
\text { 1- etanosulfonato }\end{array}$ & $\mathrm{CH}(\mathrm{OH})_{2} \mathrm{CH}(\mathrm{OH}) \mathrm{SO}_{3}^{-}$ & $2,8 \times 10^{4}$ \\
\hline Hidroxiacetaldeido & $\begin{array}{l}\text { 1,2-Dihidroxieta } \\
\text { nosulfonato }\end{array}$ & $\mathrm{CH}_{2}(\mathrm{OH}) \mathrm{CH}(\mathrm{OH}) \mathrm{SO}_{3}^{-}$ & $2,0 \times 10^{5}$ \\
\hline Ácido Glioxílico & $\begin{array}{l}\text { Ácido 2-hidroxi-2- } \\
\text { sulfoetanóico }\end{array}$ & $\mathrm{HO}_{2} \mathrm{CCH}(\mathrm{OH}) \mathrm{SO}_{3}$ & $2,4 \times 10^{5}$ \\
\hline
\end{tabular}

Com o desenvolvimento do coletor por difusão, descrito anteriormente, no qual se utiliza água deionizada como substância coletora para amostragem das espécies gasosas em questão, alcançou-se uma eficiência de coleta entre 90 e $95 \%$ para formaldeído, conforme se verá nos capítulos seguintes. Desta forma, para o formaldeído, recorre-se a derivatização através da adição de $\mathrm{HSO}_{3}^{-}$somente após a coleta quantitativa com o coletor por difusão, reduzindo a exposição ao oxigênio e, conseqüentemente, a necessidade usar grande excesso de sulfito.

Após a amostra ter sido coletada, sob as condições descritas, adicionouse $0,5 \mathrm{mmol} \mathrm{L}^{-1}$ de $\mathrm{HSO}_{3}{ }^{-}$para conversão de $\mathrm{CH}_{2} \mathrm{O}$ em HMS. Para promover formação mais quantitativa do aduto, adicionou-se também às amostras, $\mathrm{HCl}$ suficiente para que o $\mathrm{pH}$ se mantivesse em torno de 5,0; pois ao redor deste 
$\mathrm{pH}$, o sulfito em excesso encontra-se, predominantemente, na forma monoprotonada, $\mathrm{HSO}_{3}{ }^{-}$.

Para determinação analítica de formaldeído e ácidos fórmico e acético na atmosfera e/ou ambientes fechados, desenvolveu-se novo método utilizando-se um equipamento de eletroforese capilar com detecção condutométrica sem contato (CE-CCD), desenvolvido dentro do mesmo grupo de pesquisa do IQ-USP (Fracassi et al., 1998).

Assim, a coleta de formaldeído e dos ácidos fórmico e acético é feita simplificadamente em água deionizada (devido as altas constantes de Henry). Posteriormente, adiciona-se $\mathrm{HSO}_{3}^{-}$à solução coletada para derivatização do formaldeído de forma que nem os picos do $\mathrm{HSO}_{3}^{-}$, proveniente de seu excesso, nem o pico do $\mathrm{SO}_{4}^{2-}$, resultante da oxidação de parte do $\mathrm{HSO}_{3}$; interfiram nos picos das espécies coletadas.

Os eletroferogramas foram obtidos injetando a amostra por gravidade (10 $\mathrm{cm}$ por $40 \mathrm{~s}$ ) em capilar de sílica fundida de $75 \mu \mathrm{m}$ de diâmetro interno e $75 \mathrm{~cm}$ de comprimento total, promovendo a separação mediante aplicação de potencial $25 \mathrm{kV}$, ficando o pólo negativo conectado ao extremo do capilar em que se faz a injeção. A freqüência aplicada ao detector de condutividade foi de $600 \mathrm{kHz}$.

Inicialmente, o capilar era devidamente condicionado: primeiro com fluxo constante durante $30 \mathrm{~min}$ de $\mathrm{NaOH} 0,1 \mathrm{~mol} \mathrm{~L}^{-1}$, seguido de fluxo de água deionizada por 20 min e finalmente por fluxo de tampão de corrida por $40 \mathrm{~min}$. Posteriormente, aplica-se potencial de trabalho por $40 \mathrm{~min}$.

A determinação do ânion formado (HMS) foi feita em tampão de ácido 2(N-morfolino)-etanosulfônico (MES) $8 \mathrm{mmol} \mathrm{L}^{-1}$, histidina (His) $8 \mathrm{mmol} \mathrm{L}^{-1}$, acrescido de brometo de cetiltrimetilamônio (CTAB) $0,1 \mathrm{mmol} \mathrm{L}^{-1}$ como modificador de fluxo eletroosmótico, em $\mathrm{pH}$ de 6,2. A separação dos componentes encontrados foi excelente nestas condições. 
Apesar de o pico do $\mathrm{HSO}_{3}{ }^{-}$em excesso ficar suficientemente afastado do pico do HMS, quando no mesmo eletroferograma se deseja determinar simultaneamente também o formiato e acetato, os picos destes podem sofrer interferência, dependendo das condições. Quando isto ocorre, a adição de 0,25 mmol L ${ }^{-1} \mathrm{H}_{2} \mathrm{O}_{2}$, resolve o problema por conversão de $\mathrm{HSO}_{3}{ }^{-}$a $\mathrm{SO}_{4}{ }^{2-}$.

A acetona, composto carbonílico que se encontra na atmosfera, não apresentou pico detectável neste método, mesmo com adição de concentrações superiores a $100 \mu \mathrm{mol} \mathrm{L} \mathrm{L}^{-1}$.

$\mathrm{O}$ aduto formado entre o acetaldeído e $\mathrm{HSO}_{3}^{-}$possui estabilidade e mobilidade suficientes para ser detectado, porém, o limite de detecção é desfavorável, insuficiente para possibilitar sua quantificação de baixos teores nas amostras coletadas. A coleta do acetaldeído em água deionizada também é muito menos favorecida que a do formaldeído, uma vez que o mesmo apresenta baixa constante de Henry (Tabela 4.1.1.1).

Os reagentes utilizados foram de grau PA e as soluções foram preparadas com água destilada e deionizada pelo sistema Nanopure (Barnstead).

As soluções $\mathrm{H}_{2} \mathrm{O}_{2}$ e $\mathrm{HSO}_{3}{ }^{-}$foram padronizados por permanganometria, sendo a solução de permanganato padronizada contra solução de oxalato.

\subsubsection{DISPOSITIVO PARA FORMAÇÃO DE ATMOSFERA PADRÃO DE FORMALDEÍDO}

Para determinar o rendimento de coleta do sistema, produziu-se atmosfera padrão a partir da sublimação de paraformaldeído (pressão de vapor 
de $1,45 \mathrm{~mm} \mathrm{Hg}$ ). Para tanto, construiu-se um dispositivo que foi conectado ao coletor por difusão.

O dispositivo consiste de um frasco de vidro de $100 \mathrm{~mL}$, na tampa do qual foram feitos dois furos, um para entrada do fluxo de nitrogênio e outro para saída. Dentro do frasco, introduziu-se um frasco menor de vidro com capacidade de $1,5 \mathrm{~mL}$, no qual foi colocada pequena quantidade de paraformaldeido antes do seu fechamento por um septo de silicone.

Para determinar a emissão de formaldeído por permeação através do septo de silicone, o frasco foi termostatizado a uma temperatura de $30^{\circ} \mathrm{C}$ por $48 \mathrm{~h}$. A perda de massa do frasco era deteminada diariamente e o valor médio

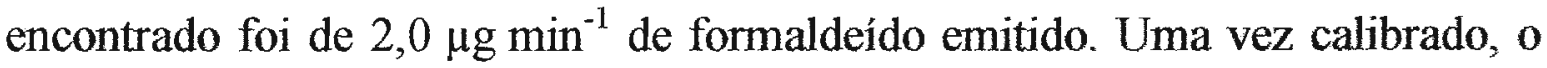
padrão foi introduzido no sistema gerador de atmosfera padrão e mantido a $30^{\circ} \mathrm{C}$. O sistema era alimentado com nitrogênio $\left(375 \mathrm{~mL} \mathrm{~min}^{-1}\right)$ e o tubo de saída era conectado diretamente, ou após diluição adicional com $\mathrm{N}_{2}$, ao coletor por difusão com membrana de Oxyphan ${ }^{(B)}$, como mostra a Figura 4.1.5.1.

A partir desse dispositivo, realizou-se várias medições com atmosfera padrão de formaldeído. Comparando-se a massa de formaldeído sublimada e massa coletada, após detecção por CE-CCD das várias medições, constatou-se uma eficiência de coleta em torno de 90 a $95 \%$.

Para comprovar a eficiência da coleta, construiu-se outro coletor por difusão que foi conectado em série com primeiro. Desta forma, a solução gasosa de $\mathrm{N}_{2} / \mathrm{CH}_{2} \mathrm{O}$ atravessa os dois coletores, verificando-se que a amostra proveniente do segundo coletor não apresentou sinal eletroforético em nenhuma das medições com atmosfera padrão. 


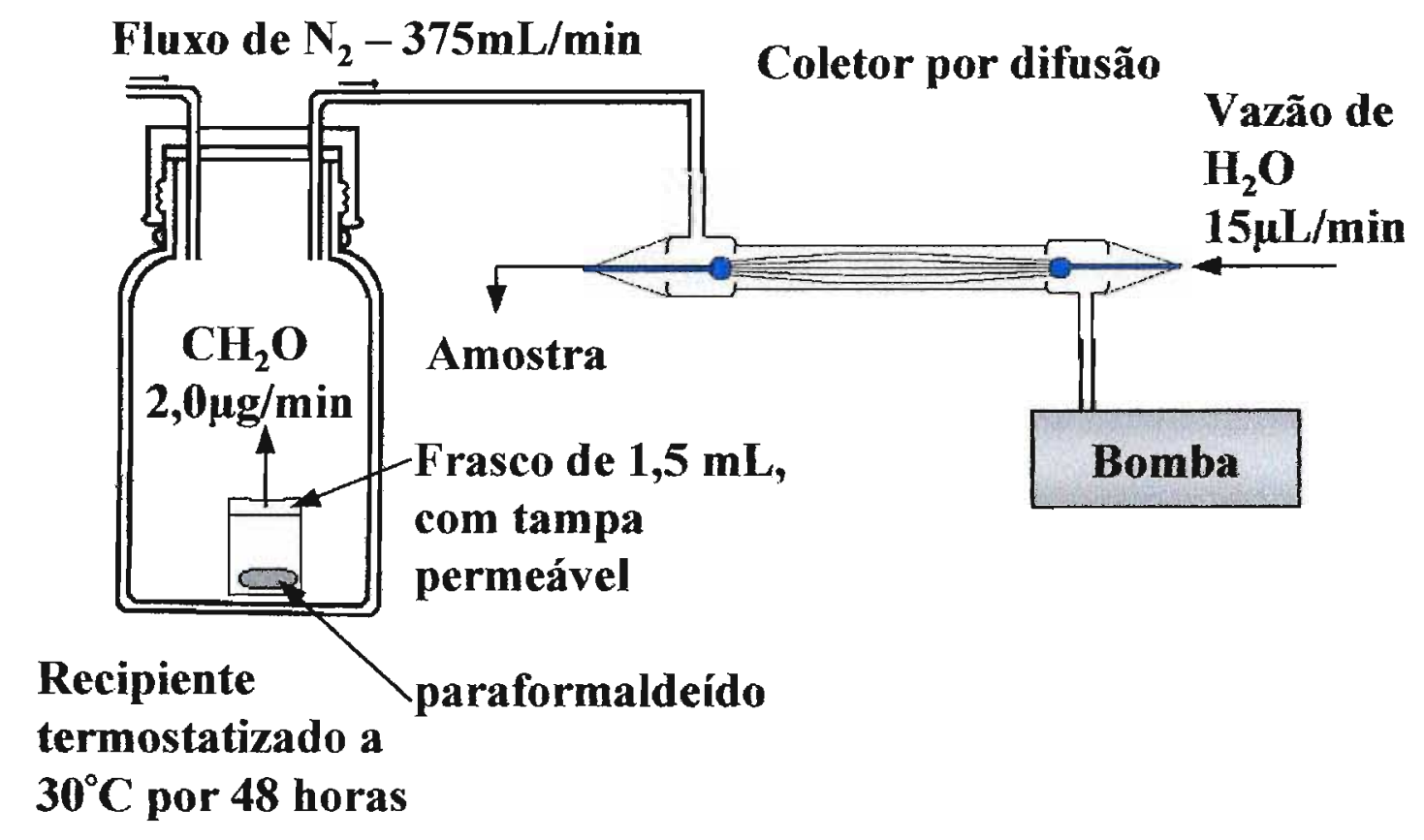

Figura 4.1.5.1 Dispositivo gerador de atmosfera padrão de formaldeído conectado a coletor por difusão (fora de escala). 


\subsubsection{RESULTADOS E DISCUSSÃO}

A metodologia desenvolvida mostrou-se efetiva para determinação de $\mathrm{CH}_{2} \mathrm{O}$ e dos ácidos fórmico e acético na fase gasosa da atmosfera, apresentando boa resolução nos eletroferogramas como mostram as análises ambientais na Figura 4.1.6.1(A).

$\mathrm{Na}$ eletroforese capilar, pequenas alterações nos tempos de eletromigração foram observadas; para contornar possíveis dúvidas na identificação do pico nos eletroferogramas de HMS nas amostras, adicionouse HMS (50 $\left.\mu \mathrm{mol} \mathrm{L}{ }^{-1}\right)$, como mostra a Figura 4.1.6.1(B).

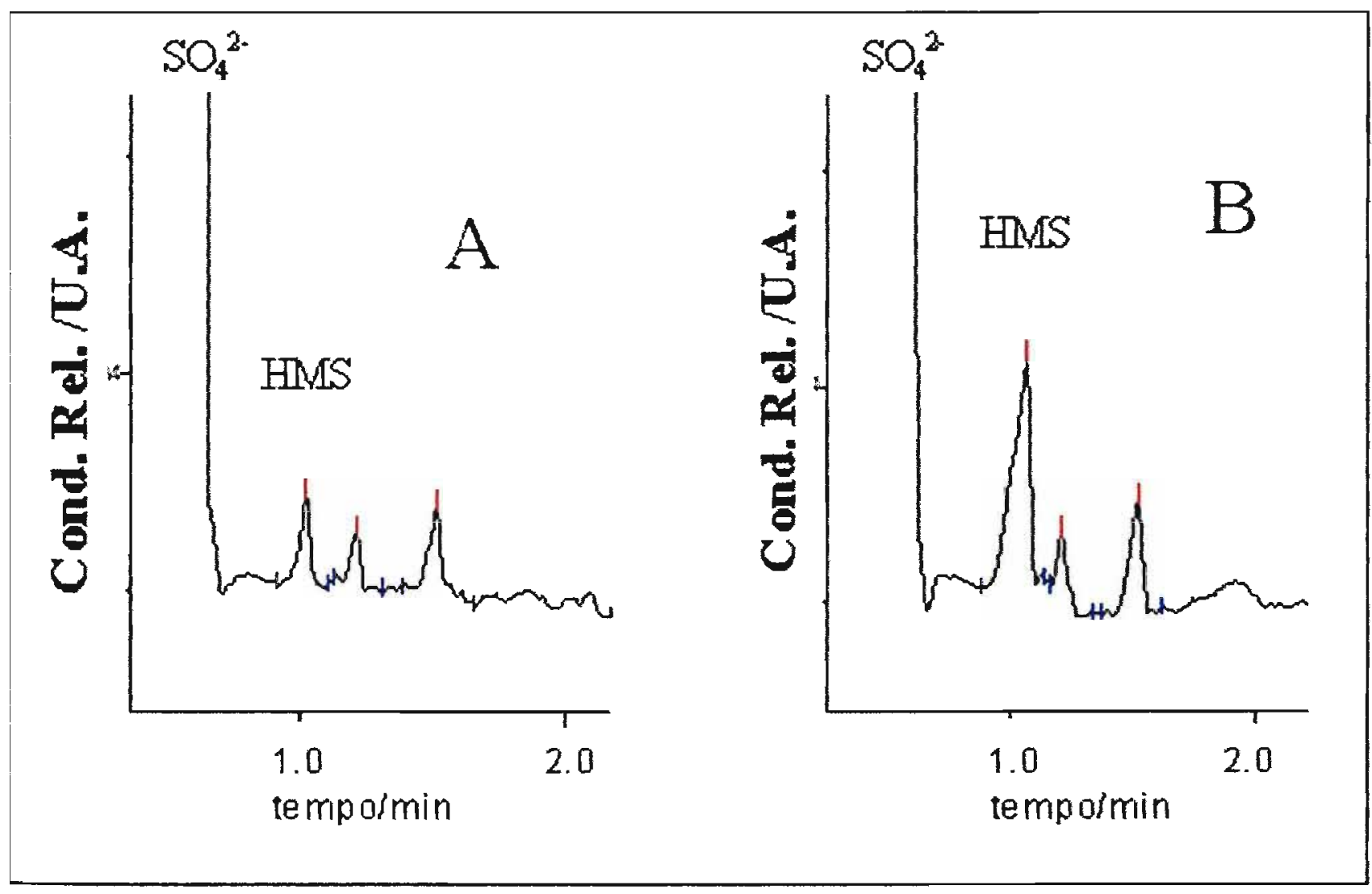

Figura 4.1.6.1 Eletroferograma de amostra de ar coletada em água $\mathrm{e}$ derivatizada para conversão do $\mathrm{CH}_{2} \mathrm{O}$ em HMS. A- sem adição de padrão; Bcom adição $50 \mu \mathrm{mol} \mathrm{L}{ }^{-1}$ de padrão de HMS. 
A metodologia desenvolvida mostrou-se também eficiente para determinação dos ácidos fórmico e acético, como demonstra o eletroferograma de padrões na Figura 4.1.6.2.

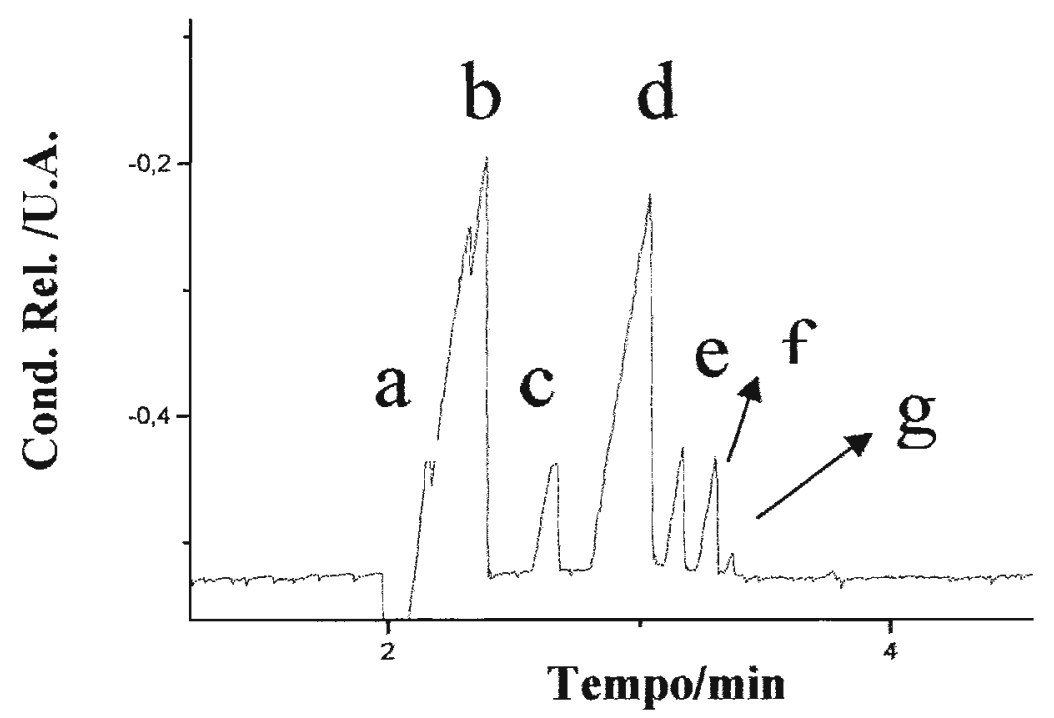

Figura 4.1.6.2 Eletroferograma de solução padrão contendo: a- $\mathrm{HCl}$

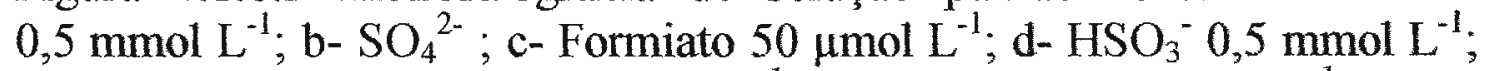
e- formaldeído (HMS) $50 \mu \mathrm{mol} \mathrm{L} \mathrm{L}^{-1}$; f- Acetato $50 \mu \mathrm{mol} \mathrm{L} \mathrm{L}^{-1}$; e gacetaldeído (HAS) $50 \mu \mathrm{mol} \mathrm{L}-1$

Nestas condições de trabalho, curvas de referência para as espécies analisadas apresentaram excelente linearidade na faixa de concentração de interesse, como mostra a Figura 4.1.6.3. 

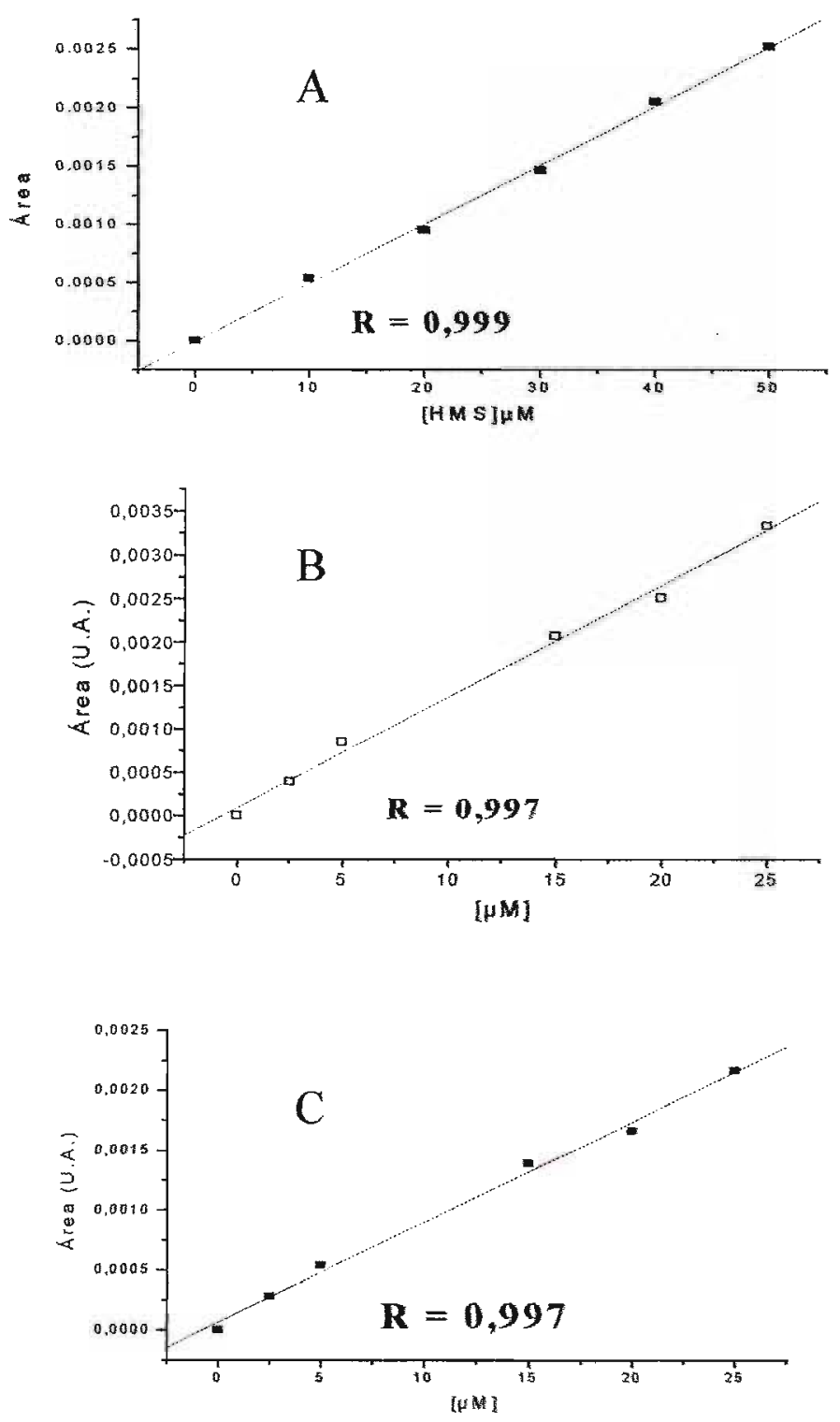

Figura 4.1.6.3 Curvas de referência para determinação de A- formaldeído; Bácido fórmico; $\mathrm{C}$ - ácido acético na fase gasosa da atmosfera. 
Para se determinar o desempenho da metodologia desenvolvida para análise de $\mathrm{CH}_{2} \mathrm{O}$ e ácidos fórmico e acético, foram coletadas amostras de ar em intervalos de uma hora durante 36 horas consecutivas nos dias 27 e 28 de agosto de 2002 (Tabela 4.1.6.1), utilizando-se o sistema de coleta por difusão com tubos porosos de polipropileno. 
Tabela 4.1.6.1 Análise de formaldeído e ácidos fórmico e acético em amostras de ar coletadas com tubos porosos de polipropileno e detecção por CE-CCD em intervalos de uma hora durante 36 horas consecutivas nos dias 27 e 28 de agosto de 2002; A - Horário da coleta; B- Temperatura; C- Umidade relativa; D- Volume de ar aspirado; E- Concentração encontrada de ácido fórmico na atmosfera $\left(\mathrm{nmol} \mathrm{L}^{-1}\right) ; \mathrm{F}$ - Concentração de ácido acético na atmosfera (nmol L1); G- Concentração de formaldeído na atmosfera $\left(\right.$ nmol L $\left.L^{-1}\right) ;-=$ não deteminado.

\begin{tabular}{|c|c|c|c|c|c|c|}
\hline $\begin{array}{c}\text { Horário } \\
\text { Coleta } \\
\text { (A) }\end{array}$ & $\begin{array}{c}\text { Temp. } \\
{ }^{\circ} \mathrm{C} \\
\text { (B) }\end{array}$ & $\begin{array}{c}\text { Umidade } \\
\text { Relativa } \\
\% \text { (C) }\end{array}$ & $\begin{array}{c}\text { Volume } \\
\text { Ar (L) } \\
\text { (D) }\end{array}$ & $\begin{array}{c}{[\mathrm{CHOOH}]} \\
(\mathrm{E})\end{array}$ & $\begin{array}{c}{\left[\mathrm{CH}_{3} \mathrm{COOH}\right]} \\
\text { (F) }\end{array}$ & $\begin{array}{c}{\left[\mathrm{CH}_{2} \mathrm{O}\right]} \\
(\mathrm{G})\end{array}$ \\
\hline $\begin{array}{c}09: 00 \text { às } \\
10: 00\end{array}$ & 30 & 27 & 20,01 & 0,01 & 0,65 & 0,02 \\
\hline $\begin{array}{c}10: 00 \text { às } \\
11: 00\end{array}$ & 27 & 30 & 20,70 & 0,05 & 0,64 & 0,07 \\
\hline $\begin{array}{c}11: 00 \text { às } \\
12: 00\end{array}$ & 27 & 30 & 18,63 & 0,08 & 0,53 & 0,10 \\
\hline $\begin{array}{c}12: 00 \text { às } \\
13: 00\end{array}$ & 28 & 30 & 20,70 & 0,08 & 0,36 & 0,09 \\
\hline $\begin{array}{c}13: 00 \text { às } \\
14: 00\end{array}$ & 29 & 27 & 18,28 & 0,09 & 0,31 & 0,09 \\
\hline $\begin{array}{c}14: 00 \text { às } \\
15: 00\end{array}$ & 30 & 25 & 20,70 & 0,04 & 0,20 & 0,09 \\
\hline $\begin{array}{c}15: 00 \text { às } \\
16: 00\end{array}$ & 30 & 23 & 17,59 & 0,09 & 0,24 & 0,12 \\
\hline $\begin{array}{c}16: 00 \text { às } \\
17: 00\end{array}$ & 29 & 22 & 20,70 & 0,08 & 0,21 & 0,13 \\
\hline $\begin{array}{c}17: 00 \text { às } \\
18: 00\end{array}$ & 28 & 26 & 18,28 & 0,08 & 0,21 & 0,14 \\
\hline $\begin{array}{c}18: 00 \text { às } \\
19: 00\end{array}$ & 26 & 29 & 20,70 & 0,08 & 0,20 & 0,16 \\
\hline $\begin{array}{c}19: 00 \text { às } \\
20: 00\end{array}$ & 25 & 29 & 20,01 & 0,05 & 0,12 & 0,12 \\
\hline $\begin{array}{c}20: 00 \text { às } \\
21: 00\end{array}$ & 24 & 36 & 20,70 & 0,06 & 0,19 & 0,19 \\
\hline $\begin{array}{l}21: 00 \text { às } \\
22: 00\end{array}$ & 24 & 41 & 20,70 & - & - & - \\
\hline $\begin{array}{c}22: 00 \text { às } \\
23: 00\end{array}$ & - & - & - & 0,06 & 0,19 & 0,23 \\
\hline $\begin{array}{c}23: 00 \text { às } \\
00: 00\end{array}$ & 22 & 48 & 15,18 & - & - & - \\
\hline $00: 00$ à & - & - & - & 0,01 & 0,05 & 0,04 \\
\hline
\end{tabular}




\begin{tabular}{|c|c|c|c|c|c|c|}
\hline $01: 00$ & & & & & & \\
\hline $\begin{array}{c}01: 00 \text { às } \\
02: 00\end{array}$ & 22 & 50 & 18,28 & - & - & - \\
\hline $\begin{array}{c}02: 00 \text { às } \\
03: 00\end{array}$ & 21 & 52 & 16,90 & 0,04 & 0,14 & 0,12 \\
\hline $\begin{array}{c}03: 00 \text { às } \\
04: 00\end{array}$ & 20 & 48 & 18,28 & 0,03 & 0,12 & 0,18 \\
\hline $\begin{array}{c}04: 00 \text { às } \\
05: 00\end{array}$ & - & - & 37,95 & - & - & - \\
\hline $\begin{array}{c}05: 00 \text { às } \\
06: 00\end{array}$ & 25 & 48 & 24,15 & - & - & - \\
\hline $\begin{array}{c}06: 00 \text { às } \\
07: 00\end{array}$ & 29 & 38 & 20,70 & 0,03 & 0,11 & 0,12 \\
\hline $\begin{array}{c}07: 00 \text { às } \\
08: 00\end{array}$ & 26 & 41 & 20,70 & 0,01 & 0,09 & 0,10 \\
\hline $\begin{array}{l}08: 00 \text { às } \\
09: 00\end{array}$ & 26 & 39 & 20,70 & 0,05 & 0,10 & 0,18 \\
\hline $\begin{array}{c}09: 00 \text { às } \\
10: 00\end{array}$ & 28 & 34 & 22,08 & 0,05 & 0,08 & 0,22 \\
\hline $\begin{array}{c}10: 00 \text { às } \\
11: 00\end{array}$ & 30 & 30 & 27,94 & 0,07 & 0,10 & 0,18 \\
\hline $\begin{array}{c}11: 00 \text { às } \\
12: 00\end{array}$ & 30 & 27 & 12,07 & 0,08 & 0,09 & 0,24 \\
\hline $\begin{array}{c}12: 00 \text { às } \\
13: 00\end{array}$ & 30 & 28 & 21,39 & 0,10 & 0,12 & 0,24 \\
\hline $\begin{array}{c}13: 00 \text { às } \\
14: 00\end{array}$ & 28 & 40 & 20,70 & 0,11 & 0,10 & 0,18 \\
\hline $\begin{array}{c}14: 00 \text { às } \\
15: 00\end{array}$ & 26 & 36 & 20,01 & 0,13 & 0,13 & 0,22 \\
\hline $\begin{array}{c}15: 00 \text { às } \\
16: 00\end{array}$ & 22 & 42 & 20,70 & 0,12 & 0,13 & 0,26 \\
\hline $\begin{array}{c}16: 00 \text { às } \\
17: 00\end{array}$ & 22 & 50 & 20,70 & 0,10 & 0,12 & 0,36 \\
\hline $\begin{array}{c}17: 00 \text { às } \\
18: 00\end{array}$ & 21 & 65 & 20,70 & 0,06 & 0,07 & 0,17 \\
\hline $\begin{array}{c}18: 00 \text { às } \\
19: 00\end{array}$ & 21 & 69. & 20,70 & 0,02 & 0,03 & 0,08 \\
\hline $\begin{array}{c}19: 00 \text { às } \\
20: 00\end{array}$ & 19 & 75 & 27,60 & 0,01 & 0,03 & 0,09 \\
\hline $\begin{array}{c}20: 00 \text { às } \\
21: 00\end{array}$ & - & - & - & 0 & 0,01 & 0,04 \\
\hline $\begin{array}{c}21: 00 \text { às } \\
22: 00\end{array}$ & - & - & - & 0 & 0,01 & 0,01 \\
\hline
\end{tabular}


Após a coleta, as amostras foram injetadas na eletroforese capilar sem tratamento prévio. Como exemplo, no eletroferograma de uma das amostras deste ciclo pode-se observar a presença dos ânions formiato e acetato; porém o $\mathrm{CH}_{2} \mathrm{O}$, por não ter mobilidade eletroforética não é detectado (Figura 4.1.6.4).

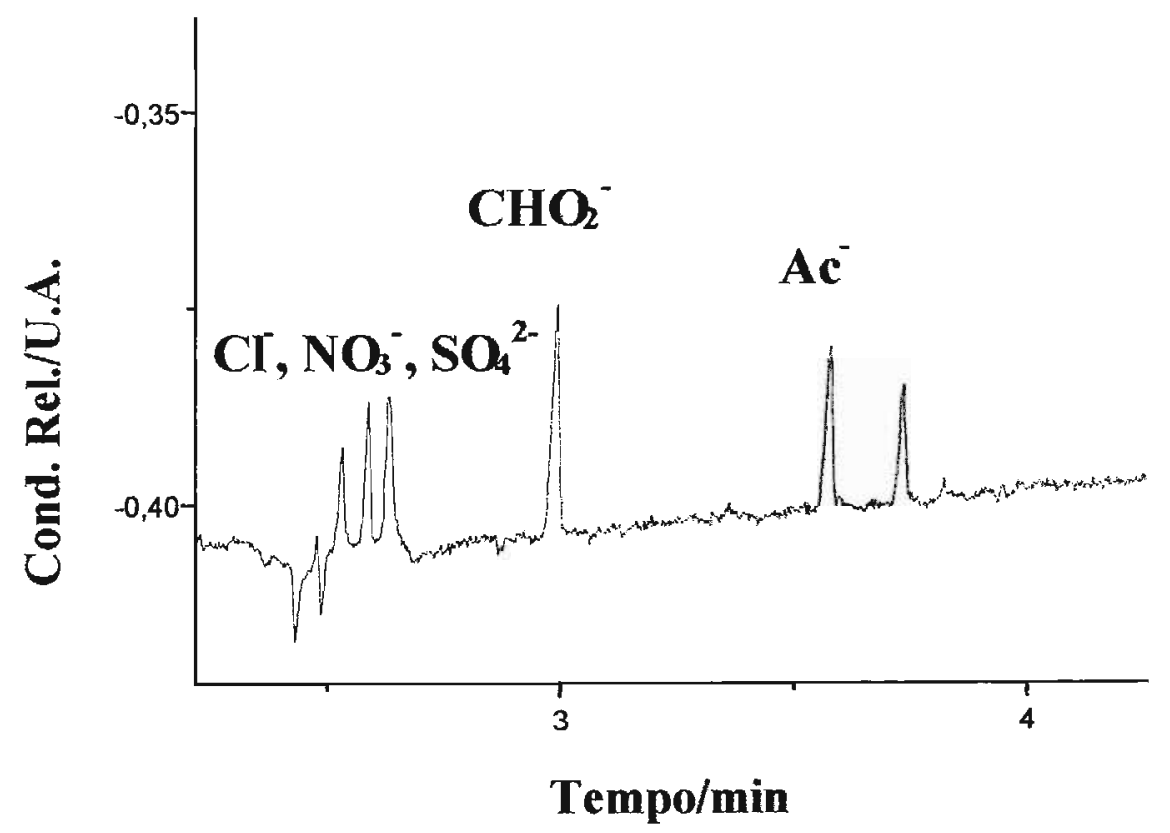

Figura 4.1.6.4 Eletroferograma de amostra coletada em 27 de agosto de 2002 para análise de formaldeído, ácidos fórmico e acético, sem adição de $\mathrm{HSO}_{3}{ }^{-}$.

Posteriormente, as amostras foram tratadas com $\mathrm{HSO}_{3}^{-} 0,5 \mathrm{mmol} \mathrm{L}^{-1} \mathrm{e}$ novamente submetidas a eletroforese. Neste eletroferograma (Figura 4.1.6.5) observa-se a presença do aduto HMS e dos ânion formiato e acetato, bem como $\mathrm{HSO}_{3}{ }^{-} \mathrm{e} \mathrm{SO}_{4}{ }^{2-}$. Devido à boa resolução encontrada entre os picos, neste caso, não houve necessidade da adição de $\mathrm{H}_{2} \mathrm{O}_{2}$ mencionada anteriormente. 


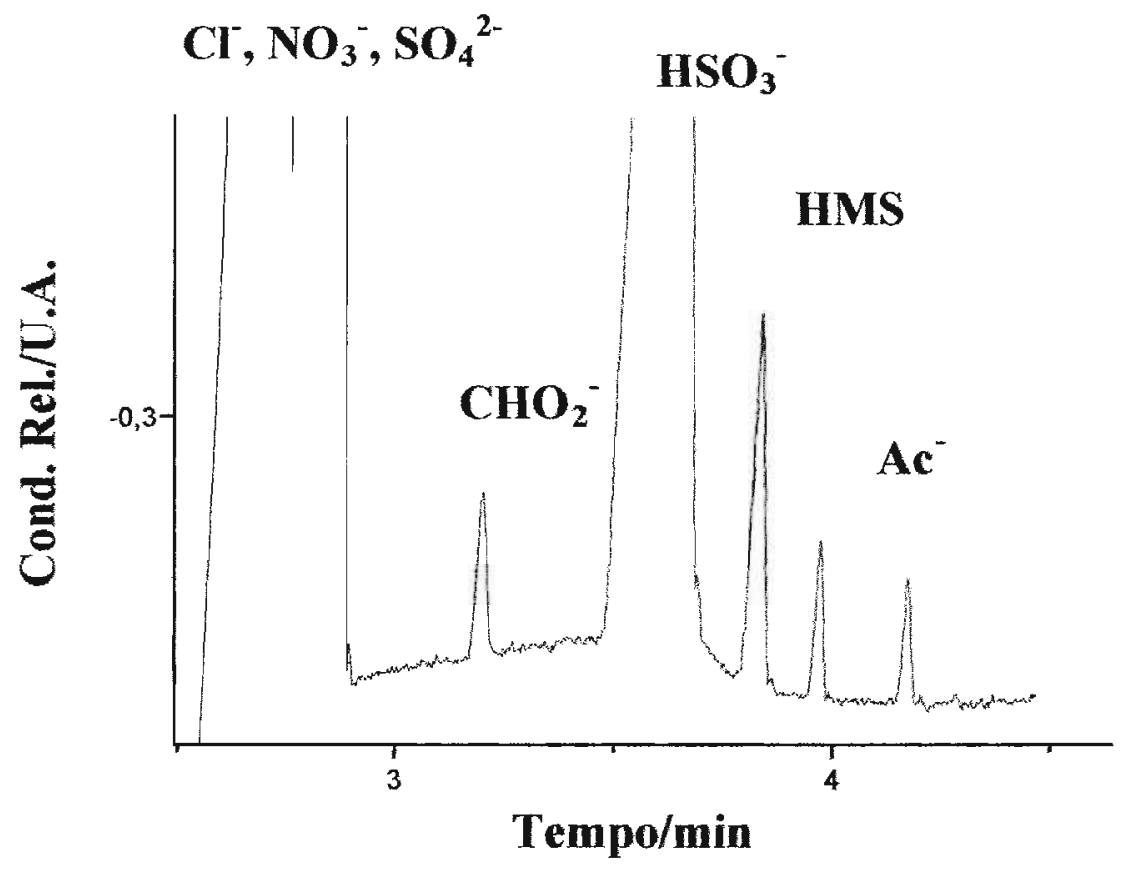

Figura 4.1.6.5 Eletroferograma de amostra coletada em 27 de agosto de 2002 para análise de formaldeído, ácidos fórmico e acético, após a adição de 0,5 mmol L ${ }^{-1}$ de $\mathrm{HSO}_{3}^{-}$.

O cálculo do volume das amostras coletadas foi feito através da diferença das massas dos frascos, utilizados para coleta, antes e depois da amostragem com o coletor por difusão. 
Posteriormente, as amostras foram tratadas e as concentrações de formaldeído e dos ácidos orgânicos, determinadas na solução coletora por CE-CCD, mediante curva de referência. Desta forma, calculou-se o número de mols das espécies nas soluções coletadas e conhecendo-se o volume de ar que foi aspirado através do coletor por difusão (medido com rotâmetro calibrado), definiu-se suas concentrações na atmosfera.

Durante a fase de desenvolvimento, as amostras foram injetadas na CE$\mathrm{CCD}$ antes e depois da adição de $\mathrm{HSO}_{3}{ }^{"}$ para demonstrar a presença dos picos dos ácidos orgânicos na ausência de sulfito e depois, com sulfito, a presença dos mesmos e também do HMS. Constatou-se, entretando, o método permite a quantificação das três espécies simultaneamente após a adição de $\mathrm{HSO}_{3}{ }^{-}$o que resulta em economia de tempos, pois só um eletroferograma precisa ser registrado.

Neste ciclo de amostragem, as concentrações de formaldeído, ácidos fórmico e acético na fase gasosa apresentaram variações de 0,01 a 0,$37 ; 0,01$ a 0,13 e 0,01 a $0,7 \mathrm{nmol} \mathrm{L}^{-1}$, respectivamente (Figuras 4.1.6.6 e 4.1.6.7). 


\section{$\left[\mathrm{CH}_{2}\right.$ O]nmol.L: ${ }^{-1}$}

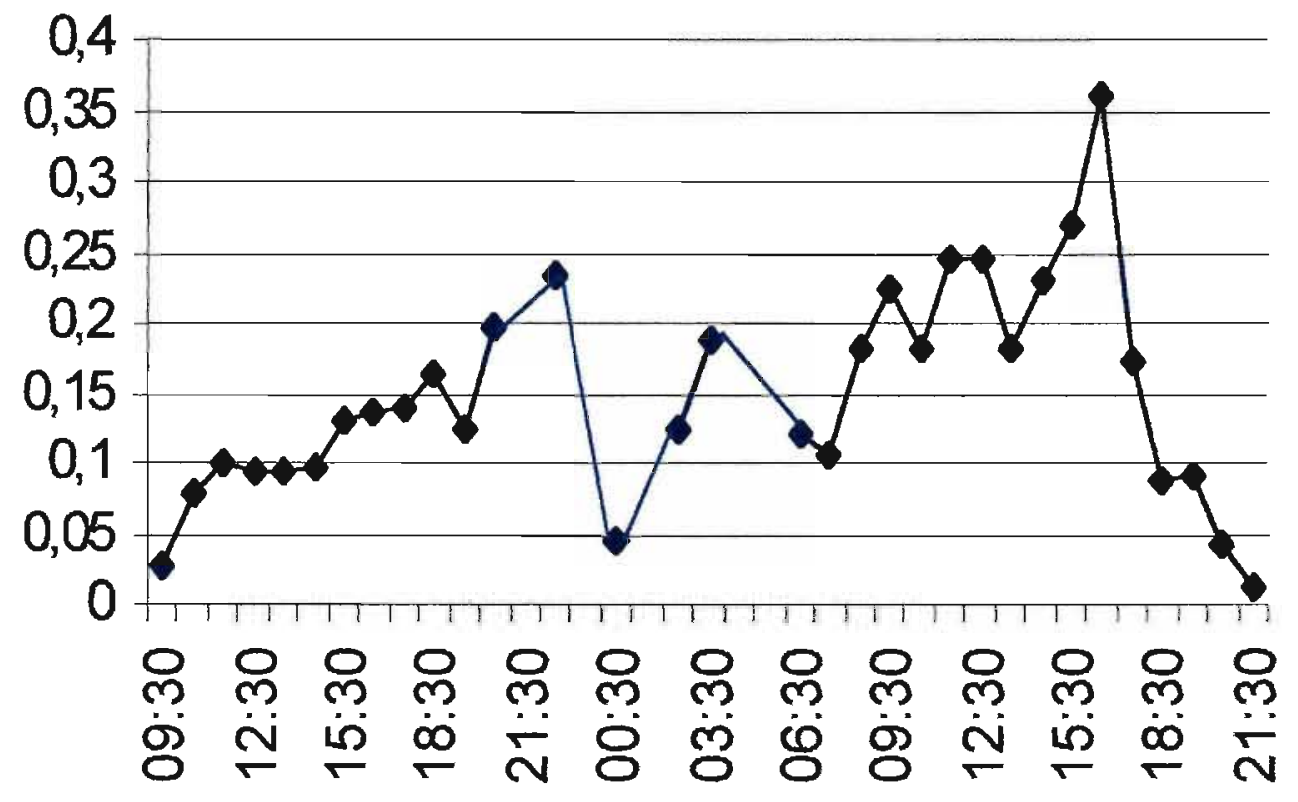

Hora do dia

Figura 4.1.6.6 Variações nas concentrações de formaldeído na fase gasosa da atmosfera em amostragem consecutiva de 36 horas em 27/28 de agosto de 2002 
[HCOOH] $\mathrm{mmoL}^{-1}$

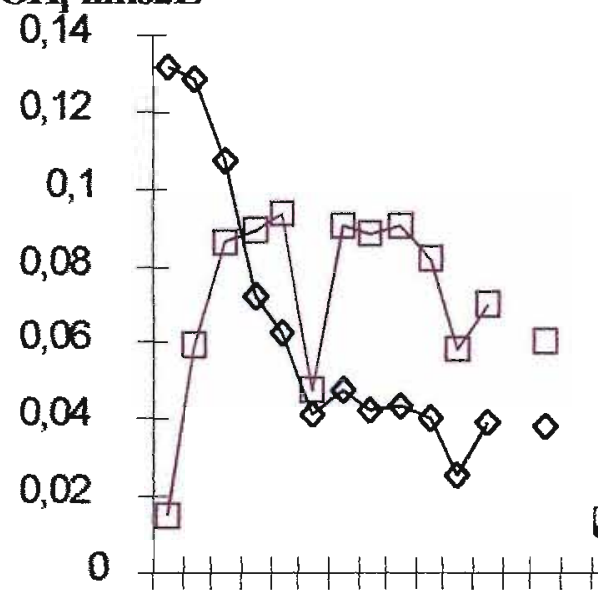

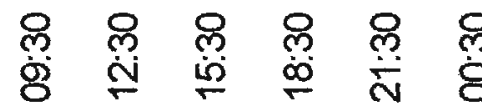

НСООН $\square$ HAc
[HAc] nmol. $\mathbf{L}^{-1}$

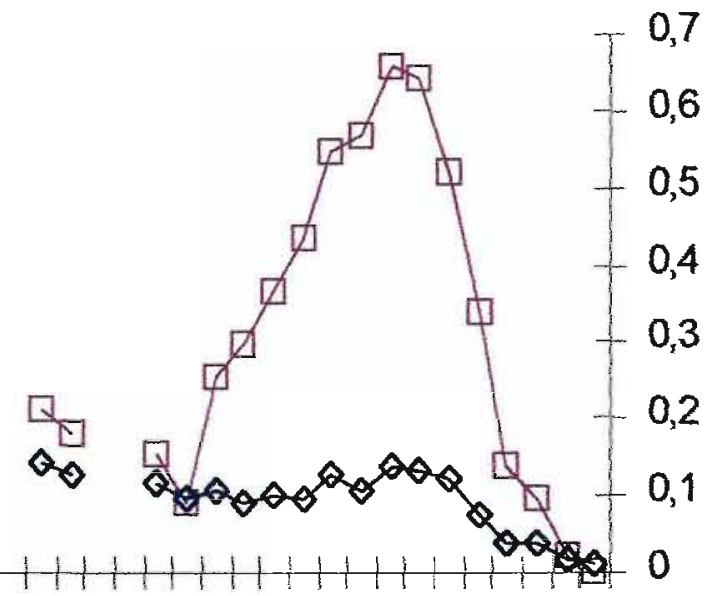

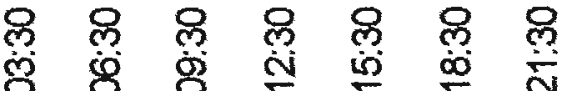

Hora do dia

Figura 4.1.6.7 Variações nas concentrações de ácidos fórmico e acético na fase gasosa da atmosfera em amostragem consecutiva de 36 horas em 27/28 de agosto de 2002 
Observando-se as concentrações de formaldeído e ácido fórmico presentes na atmosfera nas últimas 24 horas deste ciclo de amostragens, notase a relação de dependência de suas concentrações com a incidência de raios solares, ou seja, de reações fotoquímicas como fonte principal. Assim, boa correlação entre essas espécies foi observada, como mostra a Figura 4.1.6.8. De outra forma, as correlações entre formaldeído e ácido acético $(R=0,74)$ e ácido fórmico com acético $(\mathrm{R}=0,686)$ não foram tão significativas.

$\left[\mathrm{CH}_{2} \mathrm{O}\right]$ nmol.L $\mathrm{L}^{-1}$

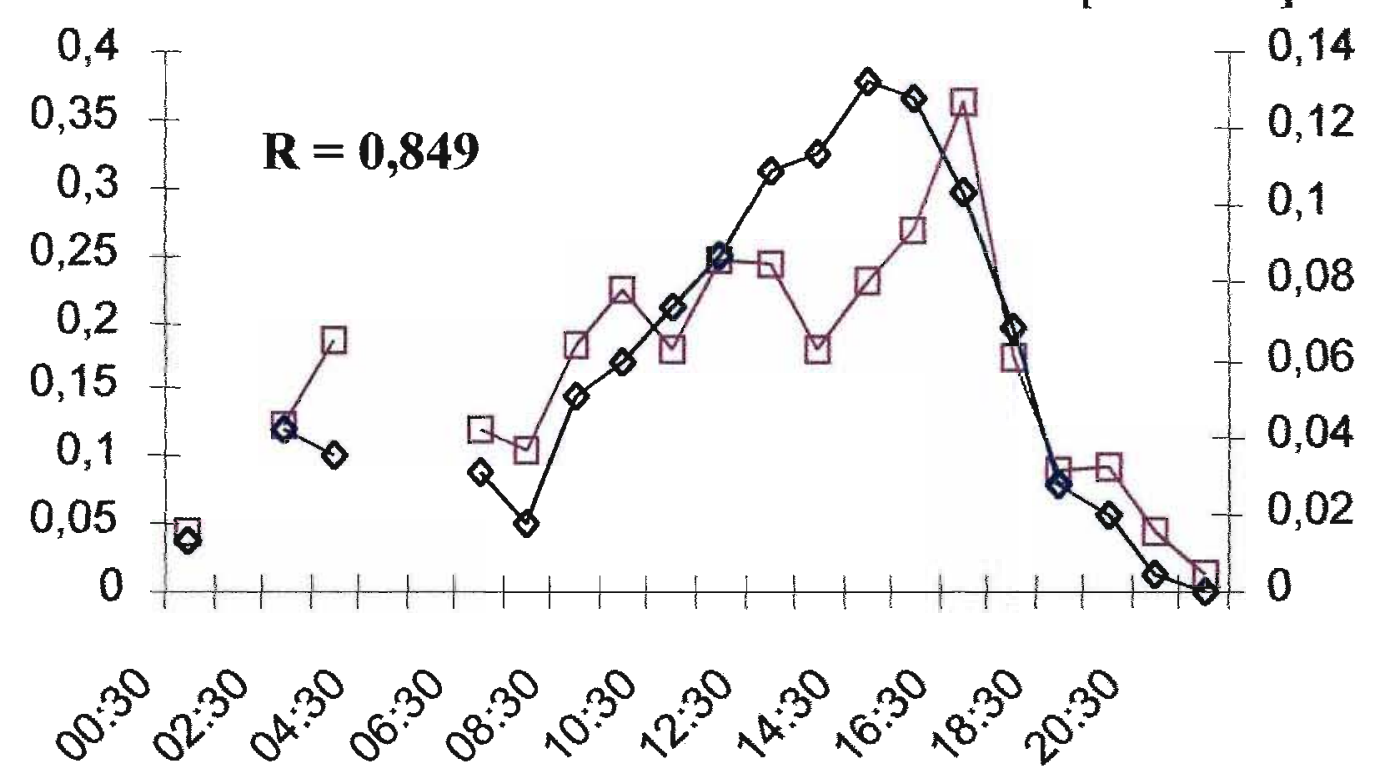

[HCOOH] nmol.L ${ }^{-1}$

$\mathrm{CH}_{2} \mathrm{O} \quad \mathrm{HCOOH}$ Hora do dia

Figura 4.1.6.8 Variação nas concentrações de formaldeído e ácido fórmico por período consecutivo de 24 horas. 
Outro ciclo de análises com o intuito de observar variações ao longo de um dia na concentração de $\mathrm{CH}_{2} \mathrm{O}$ na fase gasosa da atmosfera, foi efetuado em novembro/2000. Amostras foram coletadas por período de $36 \mathrm{~h}$ consecutivas em intervalos de $2 \mathrm{~h}$ e posteriormente analisadas (Figura 4.1.6.9). $\mathrm{O}$ perfil da variação da concentração de $\mathrm{CH}_{2} \mathrm{O}$ obtido mostrou-se semelhante ao descrito anteriormente.

A coleta iniciou-se em $20 / 11$ às $10 \mathrm{~h}$, por volta das $15 \mathrm{~h}$ ocorreu uma chuva de intensidade moderada que persistiu até aproximadamente as $18 \mathrm{~h}$, removendo grande parte dos poluentes atmosféricos, como se verifica pela queda acentuada na concentração de $\mathrm{CH}_{2} \mathrm{O}$. Contudo, sua concentração volta a aumentar por volta das $23 \mathrm{~h}$, tornando a diminuir as $3 \mathrm{~h}$ e chegando a um mínimo às $6 \mathrm{~h}$ do dia 21/11. Esta pequena elevação de concentração entre $23 \mathrm{~h}$ e $3 \mathrm{~h}$ já foi observada para $\mathrm{H}_{2} \mathrm{O}_{2}$ em outro período de amostragem, como se verá no próximo capítulo.

Cabe ressaltar, que mesmo sob precipitação atmosférica, situação em que a coleta por tubos de difusão impregnados com DNPH torna-se ineficiente, a coleta por tubos porosos de polipropileno mostrou-se muito satisfatória. 


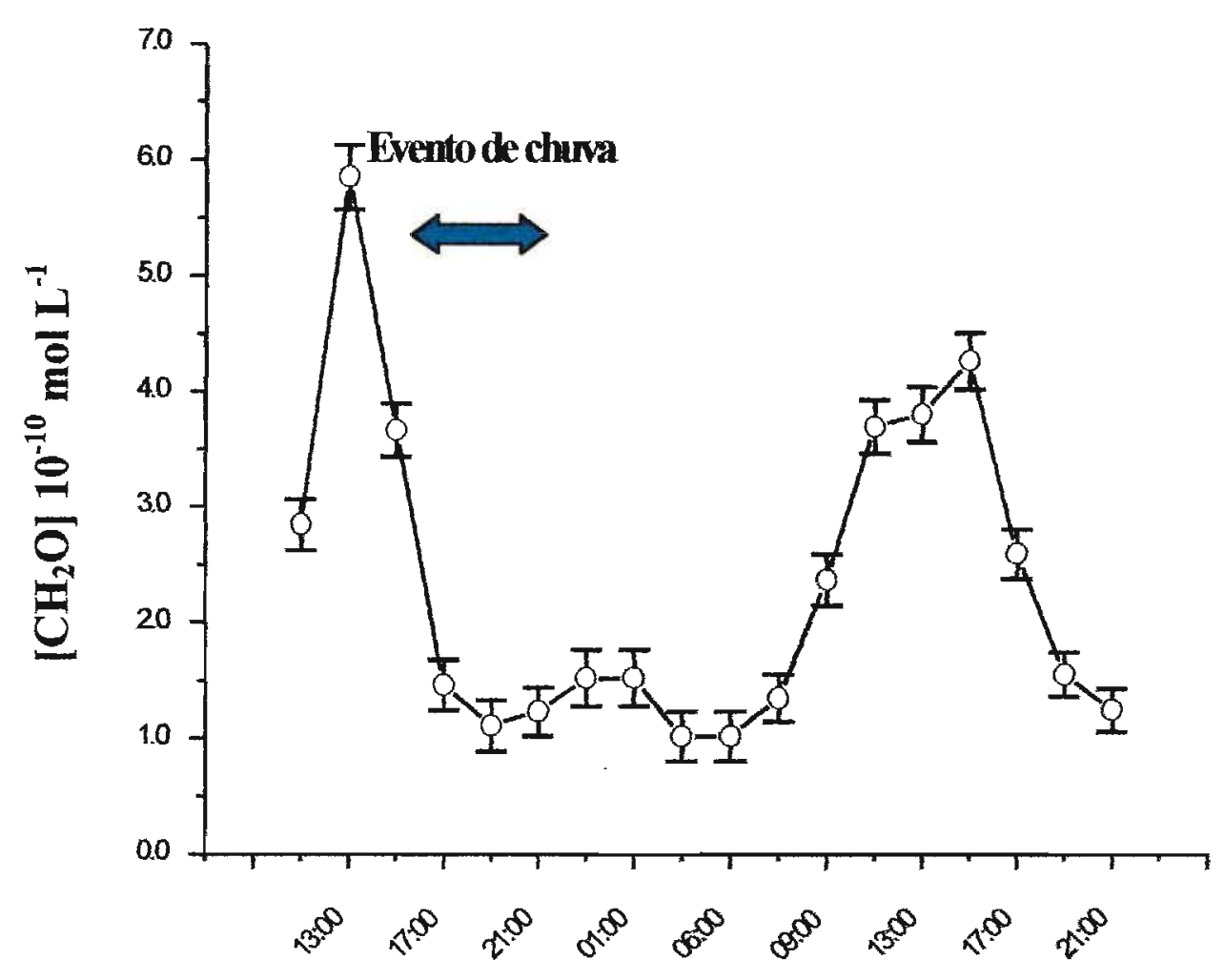

Hora do dia

Figura 4.1.6.9 Variações nas concentrações de $\mathrm{CH}_{2} \mathrm{O}$ na fase gasosa da atmosfera por período consecutivo de 36 horas em novembro de 2000.

$\mathrm{O}$ perfil das variações nas concentrações de $\mathrm{CH}_{2} \mathrm{O}$ ao longo do dia, demonstrado nas análises dos ciclos de coleta desta tese, é muito semelhante aos encontrados na literatura, como por exemplo, Manahan (1999) (Figura 1.2.1) e Environmental Health Criteria (1989) (Figura 4.1.6.10). Também, as concentrações obtidas para formaldeído e ácidos fórmico e acético estão em concordância com outros trabalhos, como mostra a Tabela 4.1.6.1. 


\section{$\left[\mathrm{CH}_{2} \mathrm{O}\right] \mu \mathrm{g} \mathrm{m}^{-3}$}

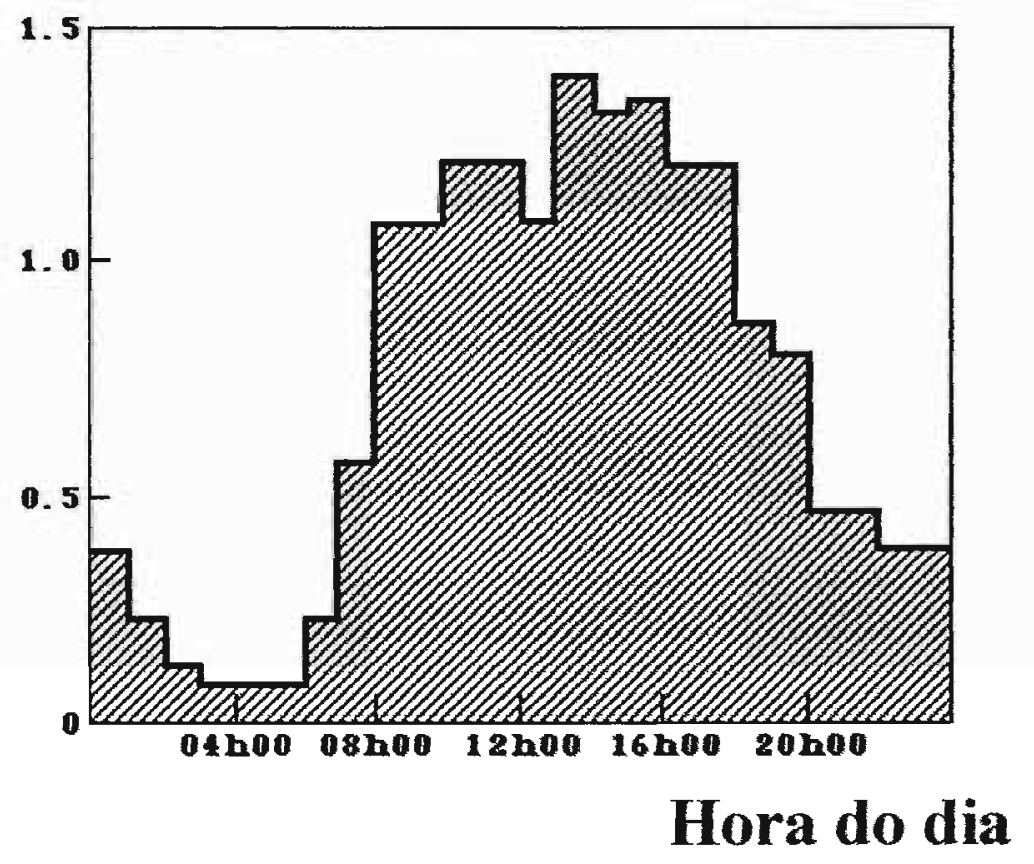

Figura 4.1.6.10 Variações na concentração de $\mathrm{CH}_{2} \mathrm{O}$ por período consecutivo de 24 horas em julho de 1982 na Áustria (reproduzido de Environmental Health Criteria (1989)). 
Tabela 4.1.6.1 Variações nas concentrações de $\mathrm{CH}_{2} \mathrm{O}$, ácidos fórmico e acético obtidas em diferentes trabalhos (ppbv). Com exceção do presente trabalho, nos demais a coleta de $\mathrm{CH}_{2} \mathrm{O}$ foi feita em cartuchos com determinação da hidrazona por HPLC. Para os ácidos carboxílicos, a amostragem foi por tubo de difusão revestido com película básica e a determinação por cromatografia de íons.

\begin{tabular}{|c|c|c|c|c|}
\hline Localização & $\mathrm{CH}_{2} \mathrm{O}$ & НСОOH & $\mathrm{CH}_{3} \mathrm{COOH}$ & Referências \\
\hline $\begin{array}{l}\text { São Paulo } \\
\text { IQ- USP }\end{array}$ & $\begin{array}{c}0,3 \text { a } 8,1 \\
\text { média } 3,3\end{array}$ & 0,1 a 2,9 & 0,3 a 3,2 & $\begin{array}{l}\text { Presente trabalho } \\
\quad(2002)\end{array}$ \\
\hline $\begin{array}{c}\text { IQ- USP } \\
(24 \mathrm{~h})\end{array}$ & $\begin{array}{l}2,4 \text { a } 12,8 \\
\text { média } 5,3\end{array}$ & - & - & $\begin{array}{l}\text { Presente trabalho } \\
\text { (2000) }\end{array}$ \\
\hline $\begin{array}{c}\text { IQ-USP } \\
\text { (inverno-1996) } \\
\text { (média de } 12 \text { dias) }\end{array}$ & 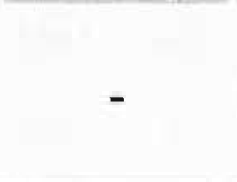 & 0,6 a 8,0 & 0,5 a 8,2 & $\begin{array}{c}\text { Souza et al. } \\
\text { (1998) }\end{array}$ \\
\hline $\begin{array}{l}\text { USP-São Paulo } \\
\text { (urbana) }\end{array}$ & 2,3 a 12,7 & - & - & $\begin{array}{c}\text { Grosjean et al. } \\
\text { (1990) }\end{array}$ \\
\hline $\begin{array}{c}\text { São Paulo } \\
\text { (média de } 5 \text { sítios) }\end{array}$ & 4,7 a 9,6 & - & - & $\begin{array}{l}\text { Miguel et al. } \\
\text { (1995) }\end{array}$ \\
\hline $\begin{array}{c}\text { Dinamarca } \\
\text { (rural) }(24 \mathrm{~h})\end{array}$ & 1,2 a 1,9 & - & - & $\begin{array}{c}\text { Christensen et al. } \\
\text { (2000) }\end{array}$ \\
\hline
\end{tabular}

O método desenvolvido apresentou sensibilidade suficiente para determinação de formaldeído e dos ácidos fórmico e acético presentes na atmosfera, sendo compatível com outros métodos descritos na literatura. Considerando que o limite de detecção alcançado por CE-CCD foi de 1,0 umol $L^{-1}$ e levando em conta a pré-concentração ocorrida na coleta quantitativa em fase aquosa, pode-se estimar um LD de aproximadamente 10 pmol L ${ }^{-1}$ de $\mathrm{CH}_{2} \mathrm{O}$ e ácido fórmico e acético na atmosfera.

Assim, a união dos sistemas de coleta e determinação analítica desenvolvidos possibilitou a análise de formaldeído e ácidos fórmico e acético simultaneamente alcançando limite de detecção na atmosfera comparáveis as técnicas comumente utilizadas. Como aperfeiçoamento futuro, pode-se pensar 
no interfaceamento direto entre o dispositivo de coleta e o equipamento de eletroforese, o que seria ideal para monitoramentos contínuos e prolongados.

A técnica de eletroforese capilar apresentou rapidez, simplicidade e versatilidade nas análises, consumindo pequena quantidade de amostras e reagentes, sendo de baixo custo operacional.

O sistema de coleta por difusão possibilita o uso de água deionizada como substância coletora para espécies com alta constante de Henry, sendo versátil para trabalhos em campo e dispensando processos de extração posterior da amostra (com agitadores mecânicos ou ultra-som) e possível formação de artefatos nesta etapa.

O fluxo de ar aspirado no sistema de coleta foi da ordem $345 \mathrm{~mL} \mathrm{~min}^{-1}$, necessitando para tanto apenas uma pequena bomba de oxigenação para aquários, dispensando o uso de potentes bombas para altas vazões. Ainda, o sistema de coleta desenvolvido é de fácil confecção e rápida montagem, utilizando materiais flexíveis de fácil manuseio como Teflon ${ }^{\text {, envolvendo }}$ baixo custo agregado.

Adicionalmente, o sistema permite a coleta de formaldeído mesmo em situações de precipitação ou umidade relativa próximas do ponto de saturação, diferentemente da coleta efetuada por "denuders" ou cartuchos impregnados com DNPH.

Diferentemente do DNPH, o derivatizante, uma solução de $\mathrm{HSO}_{3}{ }^{-}$, pode ser facilmente obtida, não necessitando de exaustivas purificações e não sendo tóxica.

Desta forma, os métodos de coleta e determinação analítica mostraramse eficientes para o propósito aqui discutido e como conseqüência natural, foram aplicados á outras espécies de interesse ambiental, apresentadas nos capítulos seguintes. 


\subsection{METODOLOGIA DESENVOLVIDA PARA DETERMI- NAÇÃO DE AMÔNIA POR ELETROFORESE CAPILAR COM DETECTOR CONDUTOMÉTRICO SEM CONTATO}

\subsubsection{CONSIDERAÇÕES GERAIS SOBRE AMÔNIA}

A determinação e o controle de gases tóxicos é de importância vital para várias aplicações na industria e meio ambiente. Nos estudos efetuados nesta tese sobre deposição úmida em São Paulo, que serão relatados nos próximos capítulos, observou-se a presença sistemática de concentrações consideráveis de $\mathrm{NH}_{4}{ }^{+}$, daí o interesse em estudar esta espécie diretamente na fase gasosa.

A amônia está presente na atmosfera como resultado de processos bioquímicos naturais, químicos e como resultado de atividades antrópicas, sendo o único gás alcalino presente na atmosfera em concentrações significantes. As principais fontes emissoras de $\mathrm{NH}_{3}$ para a atmosfera são os microorganismos, decomposição de matéria orgânica, tratamento de esgoto, produção industrial de amônia e emissão por vazamento de sistemas refrigerados com gás amônia, uso de fertilizantes, veículos automotores, etc (Andersen et al., 1999; Sutton et al., 2000; Perrino et al., 1999 e 2002). Em certas regiões, a produção agrícola é considerada responsável por aproximadamente $90 \%$ das emissões antrópicas de $\mathrm{NH}_{3}$. (Van der Hoek, 1998; Asman et al., 1987; Buijsman et al., 1987).

Em conseqüência, cerca de $10^{8}$ toneladas de amônia são emitidas para a atmosfera por ano. 
Em áreas urbanizadas estima-se que a concentração de amônia varie tipicamente de 5 a $25 \mu \mathrm{g} \mathrm{m}^{-3}$ e em áreas rurais de 2 a $6 \mu \mathrm{g} \mathrm{m}^{-3}$ (EHC 54, 1986).

A amônia é removida da atmosfera por sua afinidade com água e pelo seu carácter básico, que possibilita a formação de aerossóis em atmosfera poluída através de reações com ácidos nítrico, sulfúrico e clorídrico, formando sais de amônio como $\left(\mathrm{NH}_{4}\right) \mathrm{HSO}_{4}, \quad\left(\mathrm{NH}_{4}\right)_{2} \mathrm{SO}_{4}, \mathrm{NH}_{4} \mathrm{NO}_{3}$ e $\mathrm{NH}_{4} \mathrm{RCOO}$. Estes sais encontram-se entre os mais corrosivos encontrados no aerossol atmosférico (Manahan, 1999).

O "tempo de vida" da amônia na atmosfera é de poucos dias, enquanto o das espécies formadas por sais de amônia é de algumas semanas. Assim, a formação desses sais, geradores de aerossóis, contribui de forma significativa para o transporte a longas distâncias dessas espécies poluidoras (Aneja et al., 2000).

Tanto a amônia como seus sais são removidos mais eficientemente (mas não exclusivamente) por deposição úmida (chuva, neblina), podendo acarretar significativas mudanças no balanço de nutrientes, aumento da eutrofização ou também contribuir para acidificação do ecossistema através de sua oxidação microbiana no solo.

Em decorrência dos impactos causados pelo excesso de $\mathrm{NH}_{3}$ na atmosfera e da necessidade de propor estratégias de controle, estudos são necessários sobre a concentração de $\mathrm{NH}_{3}$ na atmosfera, bem como, melhor definição das fontes de emissão, mecanismo de transporte e fluxo das deposições seca e úmida.

$\mathrm{Na}$ Europa, dentre o conjunto de metas definido pelo protocolo de poluição do ar, propõe-se a redução de $17 \%$ nas emissões de $\mathrm{NH}_{3}$ até 2010 (Perrino et al., 2002). 
Atualmente a cromatografia de íons (CI) e a espectrofotometria com absorção no visível (após reação com azul de Indofenol) são as técnicas utilizadas e indicadas pelas organizações mundiais para determinação de amônia (NIOSH, OSHA, EPA), sendo que ambas necessitam de préconcentração. Usualmente, utilizam-se tubos de difusão ("denuders") contendo sílica gel ou pérolas de carbono impregnados com ácido sulfúrico, recomendando-se o uso de filtros para retenção do material particulado (Perrino et al., 2002).

Medidas diretas de $\mathrm{NH}_{3}$ podem ser obtidas por monitores com detecção por quimioluminescência, baseada na conversão de $\mathrm{NH}_{3}$ em NO (Aneja et al., 1978; Keuken, 1989). Porém, este método apresenta limite de detecção insuficiente para baixas concentrações de $\mathrm{NH}_{3}$ na atmosfera.

Também, monitores espectroscópios com diodo-laser baseados na absorção da radiação de infra-vermelho são utilizados na determinação de amônia, residindo sua maior desvantagem no custo do equipamento (Schiff et al., 1983).

Para pré-concentração de $\mathrm{NH}_{3}$ pode-se utilizar filtros ou "impingers" com soluções ácidas. Os filtros geralmente utilizados são Teflon ${ }^{\mathbb{k}}, N_{y l o n}{ }^{(\mathbb{R})}$, celulose ou outros substratos impregnados com ácido oxálico ou fosfórico e os "impingers" com soluções de ácido sulfúrico.

Nestes casos, há necessidade do uso de filtros antes de se efetuar a coleta nos amostradores para a retirada do material particulado contendo sais de amônio. Porém, estas formas de pré-concentração são passíveis da formação de artefatos, acarretando distorções nas medidas analíticas (Klockow et al., 1979; Perrino et al., 1999). Estas distorções ocorrem devido a perturbações no equilíbrio entre a amônia na fase gasosa e os componentes presentes no aerossol sob a forma de sais de amônio $\left(\mathrm{NH}_{4} \mathrm{NO}_{3}, \mathrm{NH}_{4} \mathrm{Cl}\right.$ e $\left.\left(\mathrm{NH}_{4}\right) \mathrm{SO}_{4}\right)$ (Allen et al., 1989). 
Resumidamente, tais amostradores são constituídos de dois filtros, sendo o primeiro, geralmente de Teflon ${ }^{\text {( }}$, para reter o material particulado e posteriormente outro filtro impregnado com solução para coletora do gás. Esse método de coleta pode ocasionar reações químicas em ambos os filtros; absorção do gás no filtro para retenção do material particulado e perturbações no equilíbrio $\mathrm{NH}_{3} / \mathrm{NH}_{4}^{+}$(Perrino et al., 1999). Tais problemas, tornam-se mais críticos em regiões com temperatura e umidade relativa elevadas.

Com a introdução de coleta através de tubos de difusão ("denuders"), já comentados anteriormente, esses problemas foram contornados em grande parte (Ferm, 1979; Possanzini et al., 1983). Neste caso, o equilibrio da partição de $\mathrm{NH}_{3} / \mathrm{NH}_{4}{ }^{+}$não é perturbado, desde que o tempo de residência dentro dos tubos de difusão seja curto (poucos décimos de segundo).

Desta forma, desenvolver metodologia que possibilite monitoramento contínuo em intervalos de tempo próximos do real para $\mathrm{NH}_{3}$ e que não necessite das longas e minuciosas preparações demandadas pelos "denuders", vem ao encontro com as necessidades atuais.

\subsubsection{COLETA DE AMÔNIA NA FASE GASOSA DA ATMOSFERA UTILIZANDO-SE COLETOR POR DIFUSÃO DE POLIPROPILENO}

Para amostragem de amônia utilizou-se o coletor por difusão descrito no Capítulo III, com capilares porosos de polipropileno (Oxyphan ${ }^{3}$ ). Todavia, por ter o $\mathrm{NH}_{3}$ solubilidade relativamente baixa (Tabela 4.1.1.1) o uso de um fluxo de coleta contento apenas água deionizada, viável para formaldeído (conforme demonstrado anteriormente), não é efetivo. Desta forma, optou-se por realizar a coleta em meio ácido, no qual o $\mathrm{NH}_{3}$ é protonado a $\mathrm{NH}_{4}{ }^{+}$. 
Desta forma, uma solução de $\mathrm{HCl} 100 \mu \mathrm{mol} \mathrm{L}^{-1}$ é impulsionada por bomba peristáltica através do feixe de filamentos $\left(\right.$ Oxyphan $\left.{ }^{(B)}\right)$ com um fluxo de $10 \mu \mathrm{L} \min ^{-1}$. Em torno dos filamentos, ar atmosférico é aspirado com uma vazão de $375 \mathrm{~mL} \min ^{-1}$ (Figura 4.2.2.1). A amônia difunde através dos poros dos filamentos, vindo a dissolver-se na fase aquosa, onde sofre protonação, perdendo a volatilidade.

A característica anteriormente citada de que os tubos microporosos de Oxyphan $^{\text {(E) }}$ retêm praticamente todo o material particulado (MP) grosso e cerca de $50 \%$ do fino, é particularmente vantajosa na presente aplicação, se comparada aos filtros usados em vários métodos, pois não há impactação das partículas com a superfície da membrana, e sim passagem tangencial das mesmas, o que deve minimizar o efeito negativo da perturbação do equilíbrio $\mathrm{NH}_{3} / \mathrm{NH}_{4}{ }^{+}$e de possíveis reações químicas entre o gás e o material retido no filtro. Comparação futura entre dispositivos com filtro, "denuders" e o aqui proposto permitiria elucidar este aspecto.

Desenvolvida a metodologia, o sistema de coleta foi montado em uma sala especial para coletas (já descrita anteriormente) e amostras de ar foram aspiradas do exterior do laboratório através de um tubo de polietileno de aproximadamente $1,5 \mathrm{~m}$.

As amostras foram coletadas em frascos (tipo vial) e determinados os volumes das soluções das amostras por diferença da massa do frasco coletor. Este procedimento de pesagem é relevante quando a umidade relativa do ar é baixa, podendo levar à evaporação parcial da solução que flui lentamente pelo feixe de capilares.

O novo método desenvolvido para determinação de amônia nas amostras por CE-CCD será descrita a seguir. 


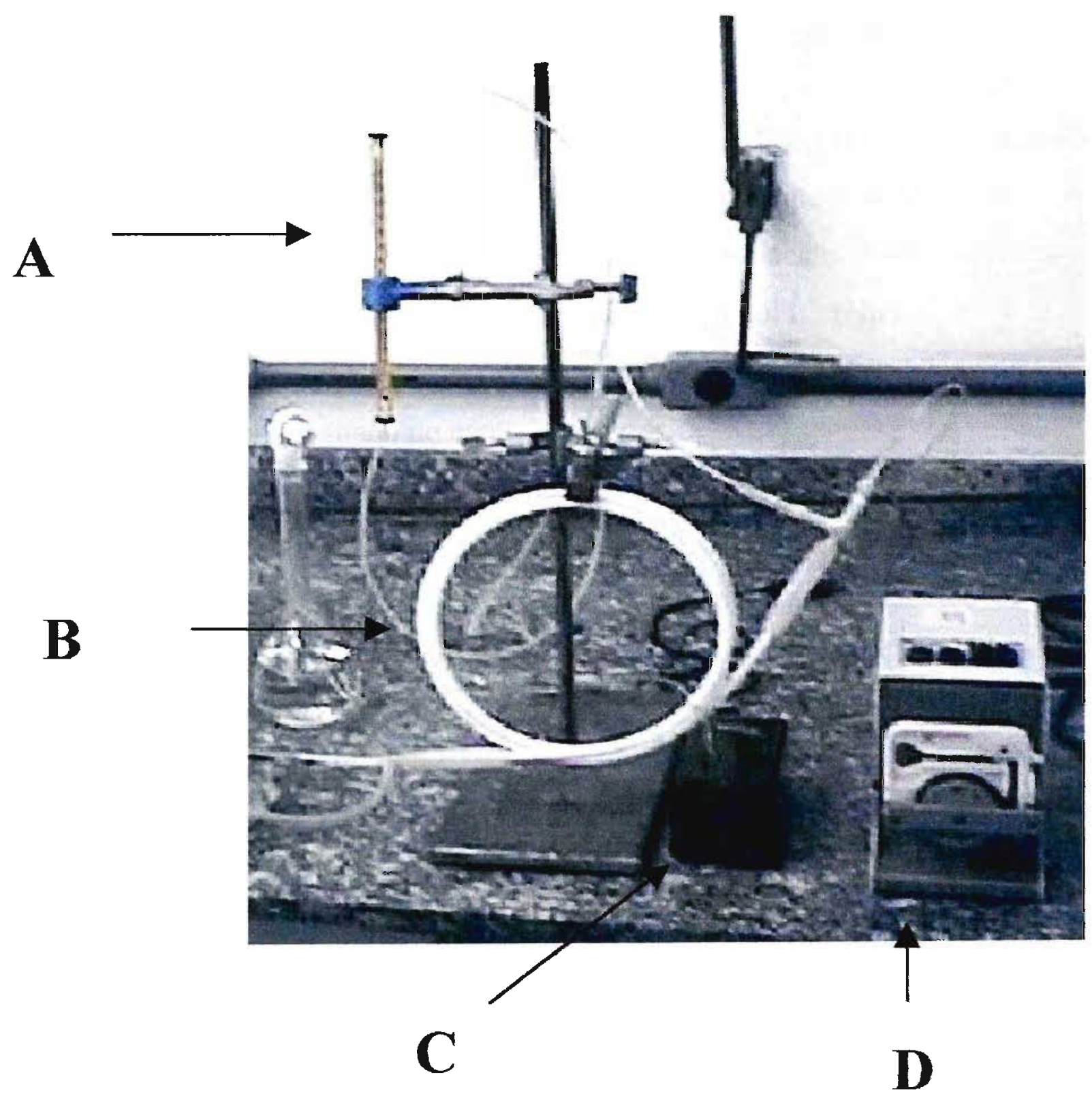

Figura 4.2.2.1 Foto do sistema de coleta por difusão para determinação de amônia na fase gasosa: A- Rotâmetro; B- Feixes de filamentos de Oxyphan ${ }^{(\mathbf{B}}$; C-Bomba de ar; D- Bomba peristáltica. 


\subsubsection{DETERMINAÇÃO DE AMÔNIA POR ELETROFO- RESE CAPILAR COM DETECTOR CONDUTOMÉTRICO SEM CONTATO NA FASE GASOSA DA ATMOSFERA}

Após a coleta, as amostras foram injetadas por gravidade $(10 \mathrm{~cm}$ por 40 s) em capilar de sílica fundida $(75 \mu \mathrm{m}, 50 \mathrm{~cm})$ e aplicando potencial $15 \mathrm{kV}$. A determinação do cátion foi feita em tampão de ácido 2-[N-morfolino]etanosulfônico (MES) $10 \mathrm{mmol} \mathrm{L}^{-1}$ e histidina $10 \mathrm{mmol} \mathrm{L}^{-1}$ (His).

Antes das injeções das amostras, o capilar era devidamente condicionado, como citado no capítulo anterior.

Para resolver o pico interferente de $\mathrm{K}^{+}$, recorreu-se a um éter coroa, $\mathrm{o}$ 18-crown-6, adicionado na concentração $2,5 \mathrm{mmol} \mathrm{L} \mathrm{L}^{-1}$. Porém, como as paredes dos tubos de Oxyphan ${ }^{(\mathbb{B})}$ retém o material particulado do ar, este cuidado pode ser dispensado em aplicações de rotina, pois nas amostras, efetivamente, os eletroferogramas não revelaram a presença de potássio.

Nestas condições, aplicou-se a metodologia desenvolvida para amostragem e determinação analítica de amônia na atmosfera a amostras reais. Os eletroferogramas (Figura 4.2.3.1) foram obtidos utilizando-se equipamento de eletroforese capilar com detecção condutométrica, com instrumentação anteriormente desenvolvida por integrantes do mesmo grupo (Fracassi et al., 1998). 


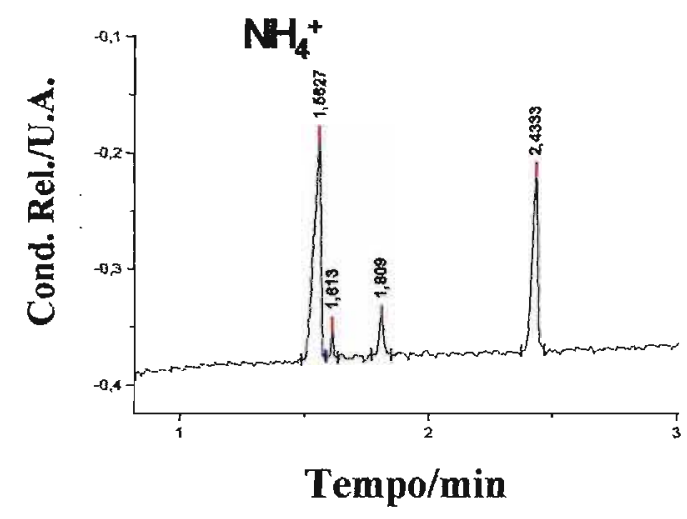

$\mathbf{A}$

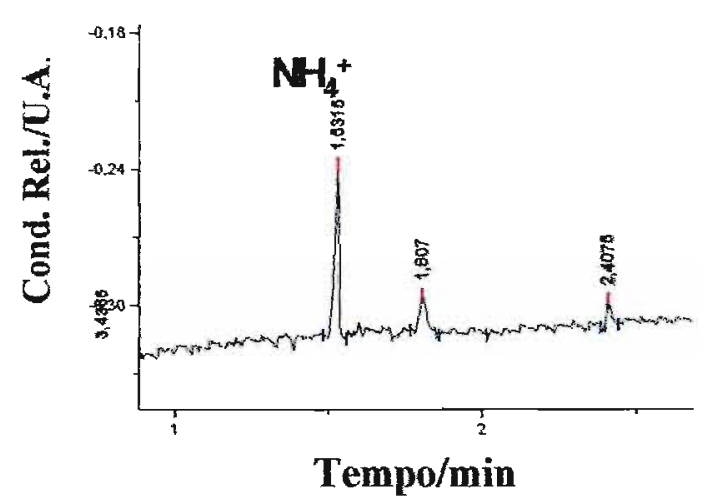

B

Figura 4.2.3.1 Eletroferograma de solução coletora com $\mathrm{HCl} 100 \mu \mathrm{mol} \mathrm{L} \mathrm{L}^{-1}$ para determinação de $\mathrm{NH}_{3}$ na fase gasosa da atmosfera utilizando o sistema coletor por difusão de Oxyphan ${ }^{(2)}$. Amostras coletadas no Cidade Universitária, São Paulo. A) dia 15/06/01; B) dia 16/06/01.

\subsubsection{RESULTADOS E DISCUSSÃO}

As metodologias desenvolvidas mostraram-se satisfatórias para amostragem e determinação analítica de amônia na atmosfera.

Nas condições descritas anteriormente, curvas de calibração para $\mathrm{NH}_{4}^{+}$ apresentaram excelente linearidade na faixa de interesse de 10 a $50 \mu \mathrm{mol} \mathrm{L} \mathrm{L}^{-1}$, conforme ilustra a Figura 4.2.4.1, e as amostras coletadas puderam ser quantificadas adequadamente. 


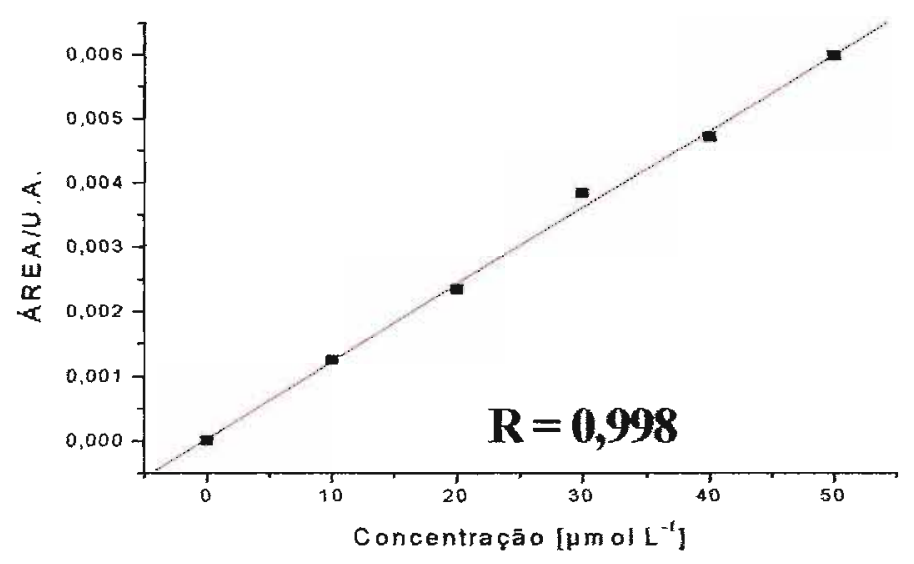

Figura 4.2.4.1 Curva de referência de $\mathrm{NH}_{4}{ }^{+}$para determinação de $\mathrm{NH}_{3}$ na fase gasosa da atmosfera em concentrações de 10 a $50 \mu \mathrm{mol} \mathrm{L}$.

Desta forma, amostras foram coletadas sucessivamente nos dias 15 e 16 de junho de 2001 e as medidas foram compiladas nas Tabelas 4.2.4.1 e 4.2.4.2. 
Tabelas 4.2.4.1 Amostras coletadas por periodos consecutivos de $6 \mathrm{~h}$ no dia 15 de junho de 2001: A- Horário de coleta; B- Temperatura; C- Umidade relativa; D- Volume de ar aspirado (L); E- Concentração de amônia na solução de coleta ( $\left.\mu \mathrm{mol} \mathrm{L}{ }^{-1}\right) ; \mathrm{F}$ - Concentração de amônia na atmosfera ( nmol L $\mathrm{L}^{-1}$ ).

\begin{tabular}{|c|c|c|c|c|c|}
\hline $\begin{array}{c}\text { Horário } \\
\text { Coleta } \\
\text { (A) }\end{array}$ & $\begin{array}{c}\operatorname{Temp}^{\circ}{ }^{\circ} \mathrm{C} \\
\text { (B) }\end{array}$ & $\begin{array}{l}\text { Umidade } \\
\text { Relativa } \\
(\%)(\mathrm{C})\end{array}$ & $\begin{array}{c}\text { Vol. Ar } \\
\text { (D) }\end{array}$ & $\begin{array}{c}{\left[\mathbf{N H}_{3}\right]} \\
\text { (E) }\end{array}$ & $\begin{array}{c}{\left[\mathrm{NH}_{3}\right]} \\
(\mathrm{F})\end{array}$ \\
\hline $\begin{array}{c}12: 00 \text { às } \\
14: 00\end{array}$ & 23 & 44 & 45 & 50,3 & 1,10 \\
\hline $\begin{array}{c}14: 00 \text { às } \\
16: 00\end{array}$ & 25 & 37 & 45 & 37,9 & 0,67 \\
\hline $\begin{array}{c}16: 00 \text { às } \\
18: 00\end{array}$ & 22 & 45 & 45 & 22,5 & 0,50 \\
\hline
\end{tabular}

Tabelas 4.2.4.2 Amostras coletadas por períodos consecutivos de 8 h no dia 16 de junho de 2001: A- Horário de coleta; B- Temperatura; C- Umidade relativa; D- Volume de ar aspirado (L); E- Concentração de amônia na solução de coleta $\left.(\mu \mathrm{mol} \mathrm{L})^{-1}\right) ; \mathrm{F}$ - Concentração de amônia na atmosfera (nmol $\left.\mathrm{L}^{-1}\right)$.

\begin{tabular}{|c|c|c|c|c|c|}
\hline $\begin{array}{c}\text { Horário } \\
\text { Coleta } \\
(\mathbf{A})\end{array}$ & $\begin{array}{c}\text { Temp. }^{\circ} \mathbf{C} \\
\text { (B) }\end{array}$ & $\begin{array}{c}\text { Umidade } \\
\text { Relativa } \\
(\%)(\mathbf{C})\end{array}$ & $\begin{array}{c}\text { Vol. Ar } \\
\text { (D) }\end{array}$ & $\begin{array}{c}\text { [NH } \\
\text { (E) }\end{array}$ & $\begin{array}{c}\text { [NH }_{3} \\
(\mathbf{F})\end{array}$ \\
\hline $\begin{array}{c}12: 00 \text { às } \\
14: 00\end{array}$ & 23 & 34 & 45 & 7,43 & 0,16 \\
\hline $\begin{array}{c}14: 00 \text { às } \\
16: 00\end{array}$ & 25 & 33 & 45 & 12,3 & 0,22 \\
\hline $\begin{array}{c}16: 00 \text { às } \\
18: 00\end{array}$ & 23 & 44 & 45 & 10,9 & 0,19 \\
\hline $\begin{array}{c}18: 00 \text { às } \\
20: 00\end{array}$ & 21 & 45 & 45 & 8,1 & 0,14 \\
\hline
\end{tabular}


As Figuras 4.2.4.2 e 4.2.4.3 mostram as variações nas concentrações de amônia na atmosfera nos dias amostrados.

Cabe ressaltar, que para amostras reais efetuou-se testes para verificar a eficiência da coleta. Assim, dois coletores por difusão foram colados em série, de maneira que o ar aspirado atravessasse os dois coletores. Em seguida, as amostras foram analisadas por CE-CCD, constatando-se a ausência de sinal eletroforético no segundo coletor para $\mathrm{NH}_{4}^{+}$.

As variações de concentração de amônia na fase gasosa da atmosfera determinadas pela metodologia descrita nesta tese foram de 2,4 a $17,0 \mu \mathrm{g} \mathrm{m}^{-3}$, valores que estariam um pouco acima do "background" de amônia conhecido na literatura ( 1 a $10 \mu \mathrm{g} \mathrm{m}^{-3}$ ), possivelmente por se tratar de um sítio de amostragem em zona urbana com alto índice de poluição. De qualquer modo, encontra-se dentro das expectativas para ambientes poluídos (5 a $25 \mu \mathrm{g} \mathrm{m}^{-3}$ EHC 54, 1986). 


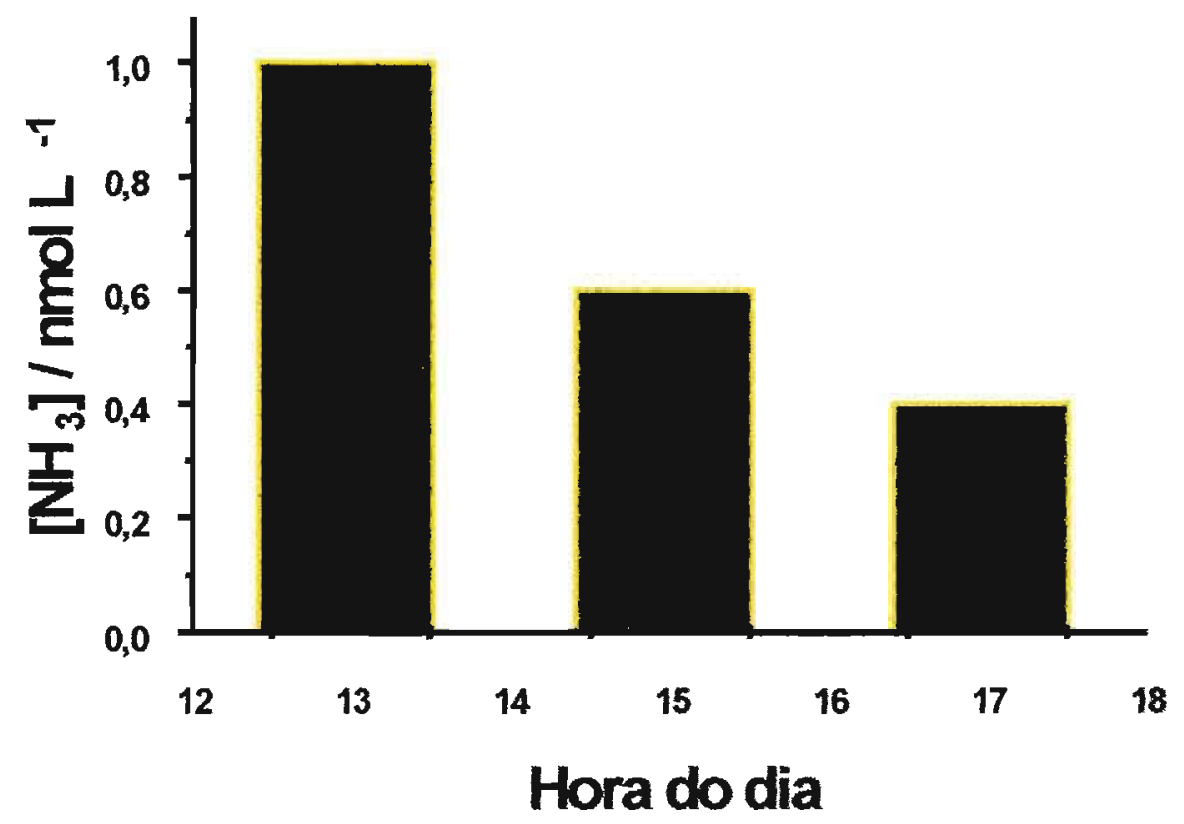

Figura 4.2.4.2 Determinação da concentração de $\mathrm{NH}_{3}$ na fase gasosa por período consecutivo de $6 \mathrm{~h}$ no dia 15 de junho de 2001

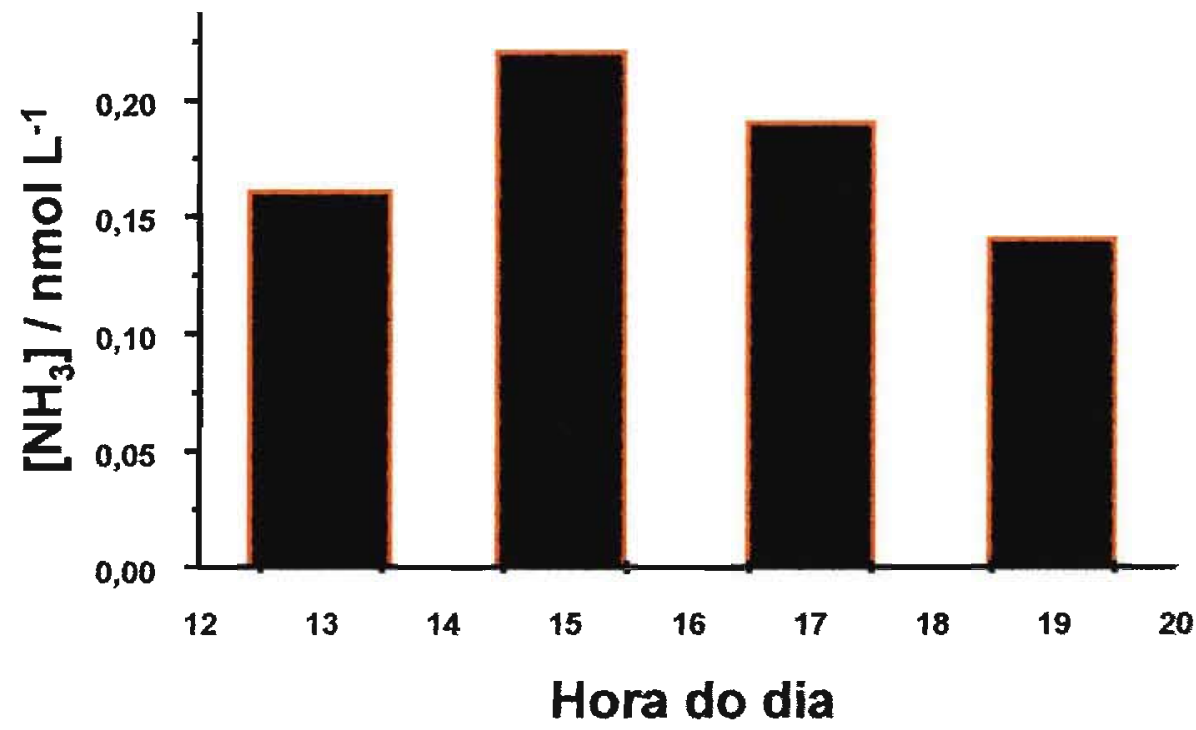

Figura 4.2.4.3 Determinação da concentração de $\mathrm{NH}_{3}$ na fase gasosa por período consecutivo de $8 \mathrm{~h}$ no dia 16 de junho de 2001 
A Tabela 4.2.4.1, mostra alguns trabalhos com concentrações de amônia determinadas em sítios urbanos e rurais, mostrando que os valores apresentados nesta tese são comparáveis aos de outros centros urbanos.

Tabela 4.2.4.1. Variações nas concentrações de $\mathrm{NH}_{3}$ em estudos realizados em algumas localidades $\left(\mu \mathrm{g} \mathrm{m}^{-3}\right)$.

\begin{tabular}{|c|c|c|c|}
\hline Local & Técnica & {$\left[\mathbf{N H}_{3}\right] \mu \mathrm{g} \mathbf{~ m}^{-3}$} & Referência \\
\hline $\begin{array}{l}\text { São Paulo } \\
\text { IQ-USP }\end{array}$ & $\begin{array}{l}\text { Tubo de difusão } \\
\left.\text { (Oxyphan }{ }^{\mathbb{B}}\right)\end{array}$ & 2,4 a 17,0 & $\begin{array}{c}\text { Presente } \\
\text { trabalho }(2002)\end{array}$ \\
\hline $\begin{array}{l}\text { Roma } \\
\text { (itália) }\end{array}$ & Denuders anular & 13,5 a 21,6 & $\begin{array}{c}\text { Perrino et al, } \\
2002\end{array}$ \\
\hline $\begin{array}{c}\text { Petten } \\
\text { (Holanda) }\end{array}$ & Termo denuder & 1,1 a 6,1 & Keuken, 1989 \\
\hline $\begin{array}{c}\text { Carolina do Norte } \\
\text { (EUA) }\end{array}$ & Denuders anular & 5,55 & $\begin{array}{c}\text { Robarge et al, } \\
2002\end{array}$ \\
\hline
\end{tabular}

O limite de deteç̧ão (3S/R) foi ao redor $0,6 \mu \mathrm{mol} \mathrm{L}^{-1}(11 \mathrm{ppb})$, correspondendo aproximadamente a $0,3 \mu \mathrm{g} \mathrm{m}^{-3}$ de amônia na atmosfera.

A metodologia descrita revelou-se apropriada para a coleta de baixas concentrações de $\mathrm{NH}_{3}$, como as encontradas na atmosfera, e sensivel e seletiva para a sua determinação. Frente aos "denuders", tem-se economia de 
tempo, vez que não há necessidade de preparar um a um, maior autonomia, por não ser requerida a troca de "denuder" após cada período de amostragem, mas somente do recipiente de estocagem (vial). Adicionalmente, a incômoda tarefa de transporte e extração do analito de cada denuder é contornada. Comparado aos "impingers", contorna-se os problemas com o material particulado nos filtros ou, quando estes não são usados, na coleta não seletiva de ambas as fases (gasosa e aerossol).

Quanto ao método de determinação, a CE-CCD compete com a CI principalmente em custo inicial e de manutenção do equipamento e das colunas e economia de reagentes. A combinação Oxyphan ${ }^{(1)}+$ CE-CCD é mais favorável que a espectrofotometria após reação com indofenol por não necessitar períodos de coleta tão longos $(24 \mathrm{~h})$ e por ser mais seletiva. 
CAPÍTULO V - METODOLOGIA DESENVOLVIDA PARA DETERMINAÇÃO DE $\mathrm{H}_{2} \mathrm{O}_{2}$ NA FASE GASOSA DA ATMOSFERA POR INJEÇÃO EM FLUXO COM DETECÇÃO AMPEROMÉTRICA EM ELETRODO DE GOTA PENDENTE DE MERCÚRIO 


\subsection{CONSIDERAÇÕES GERAIS SOBRE PERÓXIDO DE HIDROGÊNIO}

$\mathrm{O} \mathrm{H}_{2} \mathrm{O}_{2}$ começou a ser pesquisado com maior intensidade a partir de 1980 , por ter sido identificado como importante fotoxidante nas etapas de acidificação da atmosfera; além do que, possui importante papel nos processos fotoquímicos da atmosfera.

A importância do $\mathrm{H}_{2} \mathrm{O}_{2}$, no estudo da chuva ácida reside no fato de ser o oxidante fotoquímico de maior participação na oxidação de $\mathrm{SO}_{2}$ a $\mathrm{H}_{2} \mathrm{SO}_{4}$ na fase aquosa da atmosfera, após absorção do $\mathrm{SO}_{2(g)}$ e oxidantes em gotas de nuvens, neblina ou filme líquido sobre partículas de aerossóis (Beilke et al., 1978; Penket et al., 1979; Gaffney et al., 1987).

Emissões significativas de $\mathrm{H}_{2} \mathrm{O}_{2}$ por fontes diretas, naturais ou antrópicas, não são conhecidas. A principal fonte de $\mathrm{H}_{2} \mathrm{O}_{2}$ é a reação de radicais fotoquímicos hidroperoxila em fase gasosa, conforme mencionado no Capítulo I.

A elevada constante de Henry para o $\mathrm{H}_{2} \mathrm{O}_{2}$ (Tabela 4.1.1.1) justifica a sua presença em deposições úmidas como água de chuva em concentrações elevadas.

Vários métodos para determinação de $\mathrm{H}_{2} \mathrm{O}_{2}$ e de hidroperóxidos orgânicos em amostras ambientais foram desenvolvidos, com limites de deteç̧ão próximos a 50 pptv (Gunz et al., 1990; Kok et al., 1990; Hewitt et al., 1991; Lee et al., 1993; Campos et al., 1996; Parrish et al., 2000).

Segundo Parrish et al. (2000), quatro técnicas tem emergido recentemente para determinação de $\mathrm{H}_{2} \mathrm{O}_{2}$ : Derivatização Enzimática com Deteç̧ão Fluorimétrica (DEDF) (Lazrus et al., 1986; Heikes, 1992), 
Derivatização por Fenton com detecção Fluorimétrica (DFDF) (Lee et al., 1993), HPLC (Lee et al., 1995), Espectroscopia de Absorção por Tunelamento com Diodo Laser (EATDL) (Mackar et al., 1996)

As três primeiras técnicas coletam $\mathrm{H}_{2} \mathrm{O}_{2}$ de fase gasosa através de amostradores que utilizam membranas por difusão ou simplesmente através de um fluxo de água deionizada passando dentro de um tubo de vidro espiralado seguido da derivatização e detecção por fluorescência. Em Lazrus et al. (1986), a reação de derivatização ocorre entre $\mathrm{H}_{2} \mathrm{O}_{2}$ e ácido hidroxifenilacético para formar compostos fluorescentes e para conferir seletividade ao método, utiliza a enzima catalase.

No método com derivatização através de oxidações de ácido benzóico com reagente Fenton $\left(\mathrm{Fe}^{2+} \mathrm{e}_{2} \mathrm{O}_{2}\right.$ ), o produto (hidroxilato) é determinado por fluorimetria.

Na técnica HPLC são utilizados coletores por crioamostragem ou absorção em filme líquido fluindo sobre tubos espiralados ("scrubber coil"), sendo que o tempo de coleta para a crioamostragem é de tipicamente $45 \mathrm{~min}$ para o primeiro e $15 \mathrm{~min}$ com os tubos espiralados.

Stalfelbach et al. (1996) comparou as técnicas DEDF e EATDL, com derivatização enzimáticas e coletas por tubos espiralados, e a HPLC, com coleta por crioamostragem, porém com resultados não muito promissores. Em alguns períodos de coleta houve boa correlação entre as técnicas, observando uma variação de mais ou menos $20 \%$ entre as medidas. Porém, em outros períodos as variações nas medidas chegaram a $100 \%$.

Segundo Meyer et al. (1999), em ambientes internos (indústria, laboratórios, comércio, etc.) e em procesos industriais, onde se usa $\mathrm{H}_{2} \mathrm{O}_{2}$ em concentrações mais elevadas que as encontradas em amostras atmosféricas, freqüentemente se utiliza técnicas baseadas na formação de reações de 
complexação com metais (vanádio, titânio, etc.), com quantificação fotométrica dos peroxi-complexos coloridos formados.

Cabe ressaltar, os métodos eletroquímicos para determinação de $\mathrm{H}_{2} \mathrm{O}_{2}$, por possuírem sensibilidade e seletividade compatíveis com a complexidade das amostras ambientais. Entre eles, destaca-se o método amperométrico desenvolvido por Gutz e Klockow (1989), por injeção em fluxo rápido e

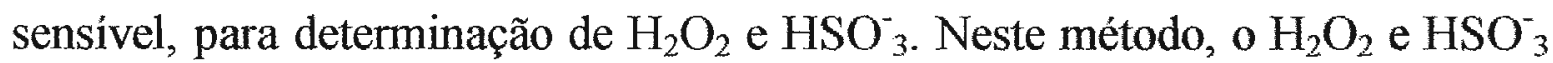
foram determinados diferencialmente por destruição seletiva a partir da utilização das enzimas catalase e sulfito oxidase, respectivamente. $\mathrm{OH}_{2} \mathrm{O}_{2}$ é determinado a $300 \mathrm{mV}$ vs $\mathrm{Ag} / \mathrm{AgCl}$ em meio alcalino $\left(\mathrm{KOH} 30 \mathrm{mmol} \mathrm{L}^{-1}\right.$ ) sem interferência de $\mathrm{HSO}_{3}^{-}$.

Gutz e Tanimoto (1991), estabeleceram condições para a determinação tanto de $\mathrm{HSO}_{3}^{-}$como $\mathrm{H}_{2} \mathrm{O}_{2}$ no mesmo meio, dispensando a duplicação do sistema FIA quando se quer fazer medições em água de chuva em "tempo real".

Estudos de peróxidos orgânicos como oxidantes na atmosfera são mais escassos que os de peróxido de hidrogênio, por sua vez, menos investigados que o ozônio. Entre os poucos métodos satisfatórios para determinação de peróxidos orgânicos em deposição úmida, tem-se o amperométrico proposto por Cramer (1995), essencialmente uma sofisticação do método de Gutz e Klockow.

Dasgupta et al. (1996) desenvolveu um coletor para $\mathrm{H}_{2} \mathrm{O}_{2}$ no qual utiliza membrana de Nylon $^{(B)}$ para difusão de $\mathrm{H}_{2} \mathrm{O}_{2}$, em um sistema em fluxo, com detecção amperométrica de processo oxidativo no eletrodo, alcançando o limite de detecção de 0,11 ppbv.

$\mathrm{Na}$ maioria dos métodos amperométricos, para determinação de $\mathrm{H}_{2} \mathrm{O}_{2} \mathrm{e}$ $\mathrm{HSO}_{3}^{-}$, foram utilizados eletrodos sólidos de ouro adquiridos comercialmente ou de platina (Gutz et al., 1989). 
No entanto, o uso dos eletrodos sólidos, com o decorrer do tempo e do número de análises, pode acarretar em inativação do eletrodo com diminuição do sinal de resposta, obrigando a calibrações periódicas e, quando a sensibilidade se torna insuficiente, a reativação da superficie do detector por via eletroquímica e/ou mecânica (polimento).

Uma possibilidade de contornar o inconveniente da gradativa inativação é o uso do eletrodo de gota pendente de mercúrio em sistemas FIA. Recentemente, em dissertação de mestrado (Rocha, 1999), desenvolveu-se um sistema FIA com eletrodo de gota pendente de mercúrio para determinação de $\mathrm{H}_{2} \mathrm{O}_{2}$ em água de chuva. Esse mesmo sistema, com algumas adaptações, foi utilizado nesta tese para determinação de $\mathrm{H}_{2} \mathrm{O}_{2}$ na fase gasosa, o qual será descrito nos capítulos seguintes.

De forma geral, as técnicas citadas para análise de $\mathrm{H}_{2} \mathrm{O}_{2}$ na fase gasosa não possuem sensibilidade suficiente para determinação direta, necessitando para tanto de sistemas de pré-concentração com transferência para a fase sólida ou líquida. Entre as alternativas citadas na literatura para a amostragem de $\mathrm{H}_{2} \mathrm{O}_{2}$ da fase gasosa tem-se: tubos coletores espiralados ("diffusion scrubers coil") (Kok et al., 1978; Lazrus et al., 1986; Lee et al., 1990; Heikes, 1992); coletores por difusão com membrana ("diffusion scrubers") (Dasgupta et al., 1990; Tanner et al., 1990); borbulhadores ("impingers") (Kok et al., 1978; Tarnner et al., 1986) ou por coleta criogênica (Sakugawa et al., 1987; Hellpointner et al., 1989; Jacob et al., 1990; Hewitt et al., 1991; Campos et al., 1996).

Os maiores problemas com interferentes ou na formação de artefatos durante ou após a transferência de $\mathrm{H}_{2} \mathrm{O}_{2}$ da fase gasosa para a fase líquida nos amostradores estão associados à presença de $\mathrm{O}_{3}, \mathrm{SO}_{2}$ e, em menor escala, alcenos. Estudos concluíram que a presença de $\mathrm{O}_{3}$ pode acarretar um aumento na concentração de $\mathrm{H}_{2} \mathrm{O}_{2}$ através da reação de $\mathrm{O}_{3}$ com $\mathrm{H}_{2} \mathrm{O}$. Por outro lado, a 
presença de $\mathrm{SO}_{2}$, produziria diminuição na concentração de $\mathrm{H}_{2} \mathrm{O}_{2}$. (Heikes, 1984; Lind et al., 1987; Campos et al., 1996).

Segundo Heikes (1984) e Sakugawa et al. (1987), a coleta de $\mathrm{H}_{2} \mathrm{O}_{2}$ em "impingers" acarreta aumento na sua concentração devido a reações entre $\mathrm{O}_{3}$ e $\mathrm{H}_{2} \mathrm{O}$ nas paredes do "impinger".

Dentre os amostradores citados, os criogênicos são os que apresentam maior potencial de pré-concentração. Entre eles, o mais difundido é o Horibe trap (Horibe et al., 1973) utilizado inicialmente para coleta de $\mathrm{CO}_{2}$.

Jacob et al. (1986) desenvolveram um coletor criogênico para $\mathrm{H}_{2} \mathrm{O}_{2}$, operando em temperatura de $-45^{\circ} \mathrm{C}$, tempo de coleta de 1 hora e detecção por qimioluminescência. Sakugawa et al. (1987) desenvolveram coletores criogênicos operando em temperaturas entre -60 e $-70^{\circ} \mathrm{C}$ com tempo de coleta de 1 a 2 horas. Após a coleta, a amostra (solidificada) foi extraída com solução de $\mathrm{HgCl}_{2}$ para complexar $\mathrm{SO}_{2}$, que possivelmente estivesse presente na atmosfera.

Vários estudos de avaliação de coletores criogênicos são encontrados na literatura (Staffelbach et al., 1995; Campos et al., 1996). Saffelbach et al. (1995) utilizaram três diferentes sistemas de coleta para $\mathrm{H}_{2} \mathrm{O}_{2}$ em seu estudo. Os sistemas envolvidos nesse estudo foram um monitor com reação enzimática para $\mathrm{H}_{2} \mathrm{O}_{2}$ e coleta por dispositivo que utilizava membrana de Nafion $^{(B)}$ com limite de detecção de 50 pptv, determinação por HPLC com coleta por tubo de difusão (Vecera et al., 1991) e Horibe trap com coleta criogênica.

Nesse estudo, comparou-se a concentração de $\mathrm{H}_{2} \mathrm{O}_{2}$ determinada pelos três sistemas citados, sendo que a coleta criogênica (Horibe trap) foi praticada em três temperaturas $\left(-79,-117 \mathrm{e}-186^{\circ} \mathrm{C}\right)$. As comparações foram feitas em atmosfera contendo cerca de 50 ppv de $\mathrm{O}_{3}$ e posterior adição de 1 ppbv de eteno e $1 \mathrm{ppm}$ de isopreno. 
Nestas condições, a coleta criogênica que obteve maior concordância com os outros sistemas foi a que operou em $-79^{\circ} \mathrm{C}$; ou seja, em crioamostragem com temperaturas em torno de $-70^{\circ} \mathrm{C}$, existe uma relativa pequena produção de artefatos de $\mathrm{H}_{2} \mathrm{O}_{2}$ (Staffelbach et al., 1995).

Cabe ressaltar, que a coleta criogênica desenvolvida nesta tese utilizou gelo seco (temperatura em torno de $-70^{\circ} \mathrm{C}$ ), como agente refrigerador, minimizando o efeito de formação de artefatos.

No intuito de testar a eficiência dos amostradores (criogênico e por difusão) desenvolvidos neste trabalho e gerar dados que, de alguma maneira, possam acrescentar informações sobre o papel do $\mathrm{H}_{2} \mathrm{O}_{2}$ na fase gasosa, amostras de ar analisadas pelo sistema coletor acoplado ao detector amperométrico, conforme descrição dada a seguir. 


\subsection{AMOSTRAGEM DE PERÓXIDO DE HIDROGÊNIO NA FASE GASOSA DA ATMOSFERA COM COLETOR POR DIFUSÃO ATRAVÉS DE TUBO MICROPOROSO E COM COLETOR CRIOGÊNICO}

Como já descrito anteriormente, na literatura encontram-se vários métodos de coletas para $\mathrm{H}_{2} \mathrm{O}_{2}$ baseados em sua alta solubilidade em água e no fato experimental de que a razão $\mathrm{H}_{2} \mathrm{O}: \mathrm{H}_{2} \mathrm{O}_{2}$ da fase gasosa se mantém praticamente inalterada na fase sólida (crioamostragem), demonstrando excelente eficiência de coleta nos dois sistemas.

Nesta tese, baseando-se nesses mesmos recursos, desenvolveu-se coletores para $\mathrm{H}_{2} \mathrm{O}_{2}$, na fase gasosa da atmosfera, através de processo difusional com membranas de Oxyphan ${ }^{\text {e }}$ por crioamostragem (ambos descritos no Capítulo III).

No coletor com um feixe de tubos microporosos de polipropileno $\left(\right.$ Oxyphan $^{(\mathrm{B})}$ ) utiliza-se água deionizada como substância coletora, impulsionada por bomba peristáltica sob uma vazão de $20 \mu \mathrm{L} \mathrm{min}{ }^{-1}$. O tubo externo de Teflon ${ }^{\circledR}$ é percorrido, em contra-fluxo, pelo ar a ser amostrado, possibilitando a difusão do $\mathrm{H}_{2} \mathrm{O}_{2}$ atmosférico para o fluxo coletor. $\mathrm{O}$ fluxo de ar foi mantido por aspiração com uma bomba de ar do tipo usado para aquários tendo a vazão sido ajustada em $375 \mathrm{~mL} \mathrm{~min}^{-1}$.

A saída do fluxo coletor do sistema de coleta por difusão é conectada diretamente na alça de amostragem do sistema FIA com detecção amperométrica em eletrodo de gota pendente de mercúrio, que será descrito a seguir, possibilitando sua injeção periódica (on-line). 
As amostras coletadas com o crioamostrador foram acondicionadas em freezer para posterior análise pelo sistema FIA-Amperométrico, a ser descrito.

Para efetuar estudos de intercomparação de amostragem de $\mathrm{H}_{2} \mathrm{O}_{2}$ na atmosfera por estes dois métodos (crioamostragem e difusão através de membrana de Oxyphan $^{(\mathbb{B})}$ ), coletou-se amostras de ar nos dias 03 e 04 de outubro de 2000 de hora em hora, por periodo de 24 horas; sendo que, as amostras criogênicas foram devidamente acondicionadas $\mathrm{e}$ analisadas posteriormente e as amostras por difusão, analisadas a cada hora (on-line).

As coletas foram feitas no IQ-USP no Bloco 12 a uma altura aproximadamente de 10 metros do solo, em laboratórios diferentes, porém próximos.

O conjunto de dados obtido das coletas efetuadas para intercomparação dos amostradores será discutido posteriormente à descrição do sistema FIAAmperométrico desenvolvido.

\subsection{DETERMINAÇÃO POLAROGRÁFICA DE $\mathrm{H}_{2} \mathrm{O}_{2}$}

Em dissertação de mestrado anterior (Rocha, 1999) desenvolveu-se método para determinação de $\mathrm{H}_{2} \mathrm{O}_{2}$ na fase líquida da atmosfera (água de chuva).

A partir de estudos iniciais em células polarográficas estacionárias propôs-se um método que utiliza eletrodo de gota pendente de mercúrio (EGPM), por ser facilmente renovável e mais reprodutível que os eletrodos sólidos. 
O processo de redução do oxigênio se dá em duas etapas, no EGPM, sendo que a primeira etapa corresponde à redução do oxigênio a peróxido de hidrogênio (Heyrovsky et al., 1996):

$$
\mathrm{O}_{2}+2 \mathrm{e}^{-}+2 \mathrm{H}^{+} \rightleftarrows \mathrm{H}_{2} \mathrm{O}_{2}
$$

à segunda, a redução do peróxido a água:

$$
\mathrm{H}_{2} \mathrm{O}_{2}+2 \mathrm{e}^{-}+2 \mathrm{H}^{+} \rightleftarrows 2 \mathrm{H}_{2} \mathrm{O}
$$

Em $\mathrm{pH}$ inferior a 9 ambas as ondas são irreversíveis. Todavia, em $\mathrm{pH}$ 11 ou superior, a primeira onda torna-se reversível. Assim sendo, após eliminação cuidadosa do $\mathrm{O}_{2}$ dissolvido, pode-se considerar a determinação de $\mathrm{H}_{2} \mathrm{O}_{2}$ numa solução tanto pela sua redução a água como, em $\mathrm{pH}$ suficientemente elevado, pela sua oxidação a $\mathrm{O}_{2}$. Desta forma, optou-se pelo processo de oxidação para a determinação analítica do peróxido, por ser pouco susceptível à presença de oxigênio dissolvido.

Resumidamente, em estudos iniciais desenvolvidos no mestrado citado, gerou-se um conjunto de polarogramas obtidos em eletrólito com $\mathrm{pH}$ próximo a 12 (Figura 5.3.1). A partir dos valores das correntes de difusão extraídas dos polarogramas construiu-se uma curva de referência que demonstrou boa linearidade $(\mathrm{R}=0,998)$. $\mathrm{O}$ potencial de meia onda manteve-se constante em $-0,15 \mathrm{~V}$, apontando para a reversibilidade do processo neste $\mathrm{pH}$. 


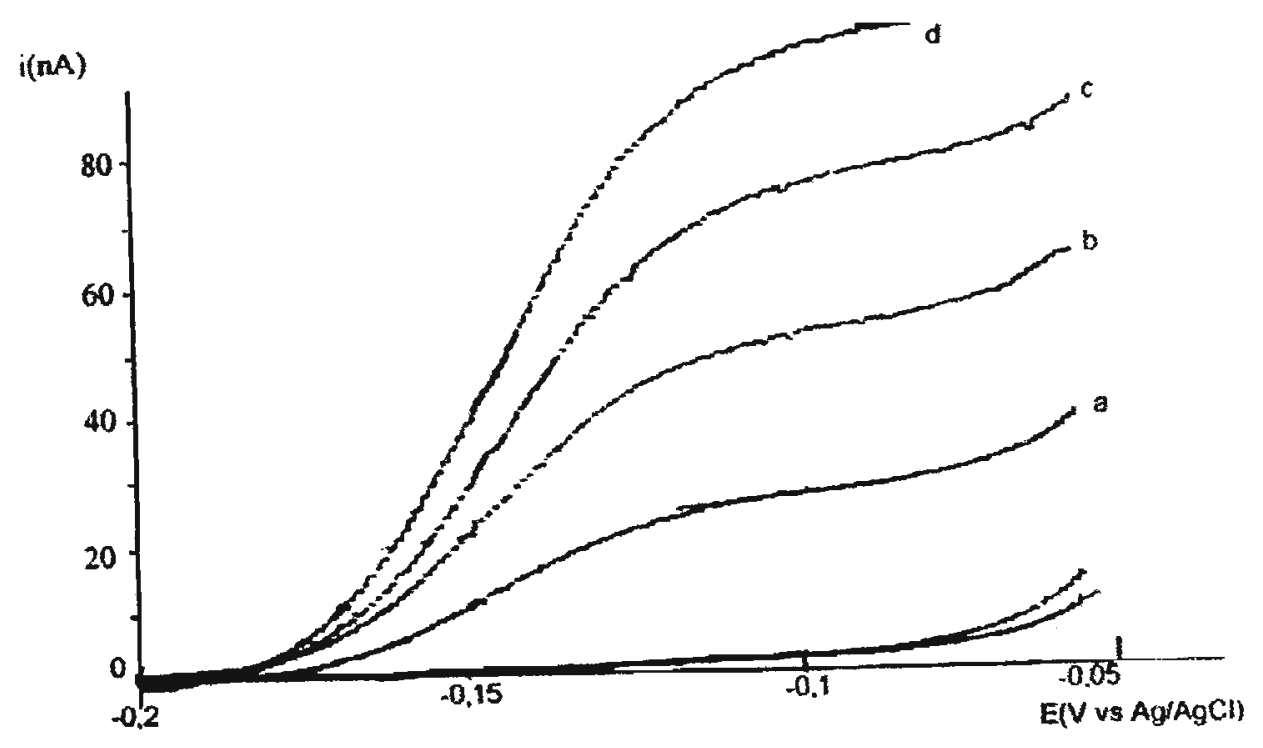

Figura 5.3.1 Polarogramas de soluções de $\mathrm{H}_{2} \mathrm{O}_{2}$, nas concentrações: a - 10; b- 20 ; c- 30 ; d- $40 \mu \mathrm{mol} \mathrm{L}^{-1}$, tempo de gotejamento de $1 \mathrm{~s}$, velocidade de varredura de $1,08 \mathrm{mV} \mathrm{s}^{-1}$, eletrólito suporte de $\mathrm{NaOH}, \mathrm{pH} 12$ (Rocha, 1999).

As medidas eletroanalíticas foram realizadas com o polarógrafo Polarecord, modelo E 506 da Metrohm Herisau, conectado a célula eletroquímica modelo 663 VA Stand da Metrohm. O eletrodo de trabalho usado foi o eletrodo de gota pendente de mercúrio, HMDE, renovável. O eletrodo de referência foi do tipo $\mathrm{Ag} / \mathrm{AgCl}$ e como contra-eletrodo, um fio de platina. 
As células eletroquímicas comerciais com EGPM, inclusive a da Metrohm, destinam-se a operações estacionárias (Figura 5.3.2). Para contornar o problema, foi desenvolvido um dispositivo simples que permite adaptar as células estacionárias a condição de fluxo.

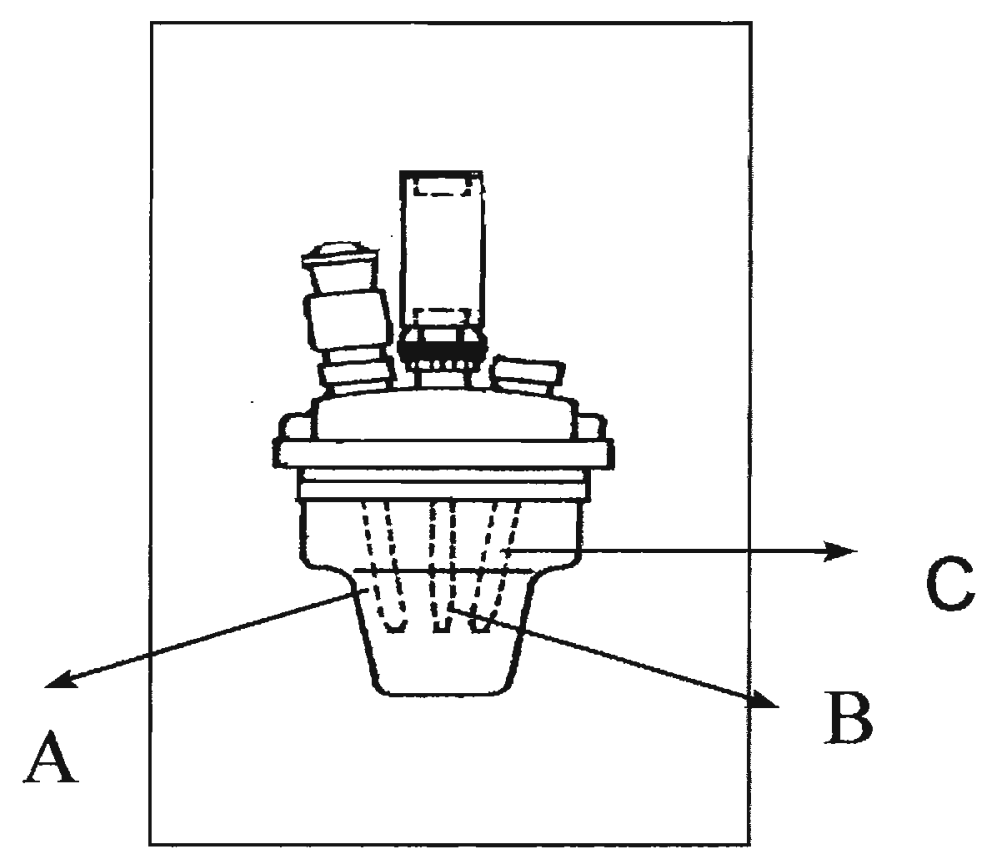

Figura 5.3.2 Representações da célula eletroquímica modelo 663VA Stand da Metrohm: A- Eletrodo de referência $(\mathrm{Ag} / \mathrm{AgCl})$; B- Eletrodo de trabalho $(\mathrm{Hg})$; C- Eletrodo auxiliar (Pt).

\subsection{DISPOSITIVO PARA VIABILIZAR ANÁLISE EM FLUXO EM CÉLULA ELETROQUÍMICA ESTACIONÁRIA}

O novo dispositivo, desenvolvido para adaptação de célula eletroquímica estacionária a fluxo, consiste em uma ponteira descartável de 
pipetador de $100 \mu \mathrm{L}$ e um tubo de silicone, o qual é adaptado sob pressão ao EGPM e perfurado lateralmente.

A ponteira de pipeta é cortada de modo que a gota de mercúrio fique exposta ao fluxo analítico e introduzida no furo lateral do tubo de silicone, que serve de suporte, para ser conectada ao sistema FIA (Figuras 5.4.1 e 5.4.2). Este dispositivo para análise em fluxo em células estacionárias é o mesmo utilizado para análise de espécies de S(IV) em vinho, que será detalhado nos próximos capítulos.

Os testes foram feitos com o Polarógrafo Polarecord e célula eletroquímica VA Stand 663 da Metrohm, mantendo-se o potencial de trabalho em $-0,07 \mathrm{~V}$ vs $\mathrm{Ag} / \mathrm{AgCl}$ em eletrólito suporte de $\mathrm{NaOH} 10 \mathrm{mmol} \mathrm{L} \mathrm{L}^{-1}$, condição em que a remoção de $\mathrm{O}_{2}$ não é crucial. Porém, para minimizar a corrente residual utilizou-se um desoxigenador anteriormente desenvolvido (Pedrotti et al., 1994) com pequenas adaptações, inovando-se em sua construção a inclusão de mais uma via de fluxo e um dispositivo que permite a convergência das duas vias de fluxo dentro do desoxigenador, o qual será descrito a seguir. 


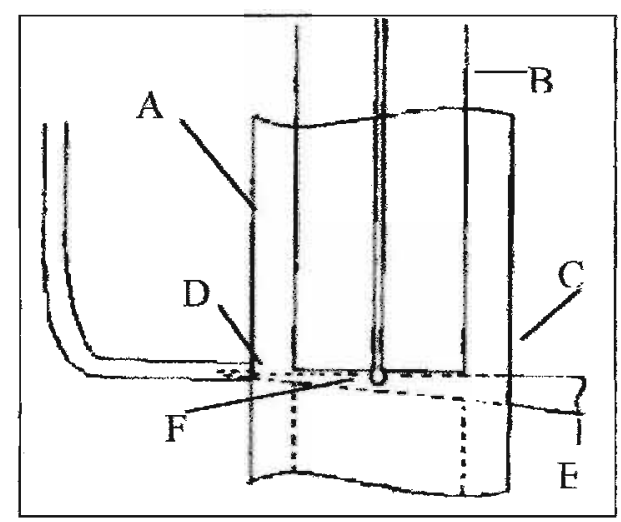

Figura 5.4.1 - Dispositivo que viabiliza a análise em fluxo em células eletroquímicas estacionárias comerciais com eletrodo de mercúrio: A - tubo de silicone; B - Eletrodo Gotejante de Mercúrio; C - perfuração do tubo de silicone; D - conexão com o comutador/injetor; E - saída do fluxo; F - corte da ponteira.

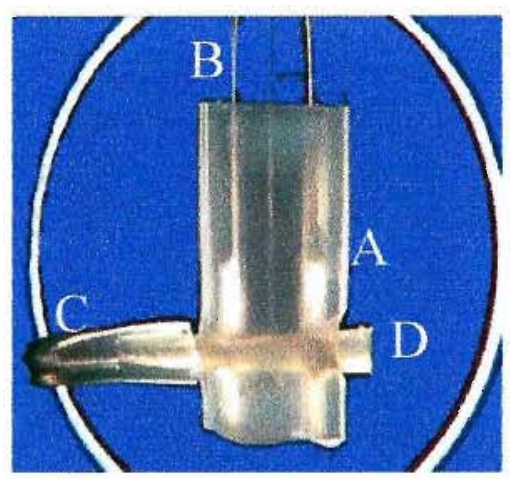

Figura 5.4.2 Foto do dispositivo que viabiliza a análise em fluxo em células eletroquímicas estacionárias comerciais com eletrodo de mercúrio: $\mathrm{A}$ - tubo de silicone; B - Eletrodo Gotejante de Mercúrio; C - conexão com o comutador/injetor; D - ponteira de pipetador $(100 \mu \mathrm{L})$. 


\subsection{DESOXIGENADOR PARA SISTEMA EM FLUXO}

Além de pequenas adaptações, a partir de um eficiente dispositivo para desoxigenação em sistemas em fluxo para eletrodo de mercúrio desenvolvido por Pedrotti et al. (1994), inovou-se em sua construção ao incluir mais uma via de fluxo e um dispositivo para convergência das linhas de fluxo, dentro do desoxigenador.

$\mathrm{O}$ desoxigenador construído neste trabalho (Figura 5.5.1) consiste de frasco de vidro(A) com capacidade de $100 \mathrm{~mL}$, com vedação hermética. $\mathrm{Na}$ tampa do frasco (B) foram feitos quatro furos: para as duas entradas das soluções (C e D), para a conexão com a bomba de vácuo $(E)$ e para a saída das soluções (F). Ambas as vias consistem de tubos capilares de silicone (H) com $3 \mathrm{~m}$ de comprimento, unidos na saída por conector em forma de y $(G)$.

No sistema desenvolvido para determinação de $\mathrm{H}_{2} \mathrm{O}_{2}$ em fluxo, o qual será descrito a seguir, o desoxigenador é mantido sob pressão negativa por bomba de vácuo. 


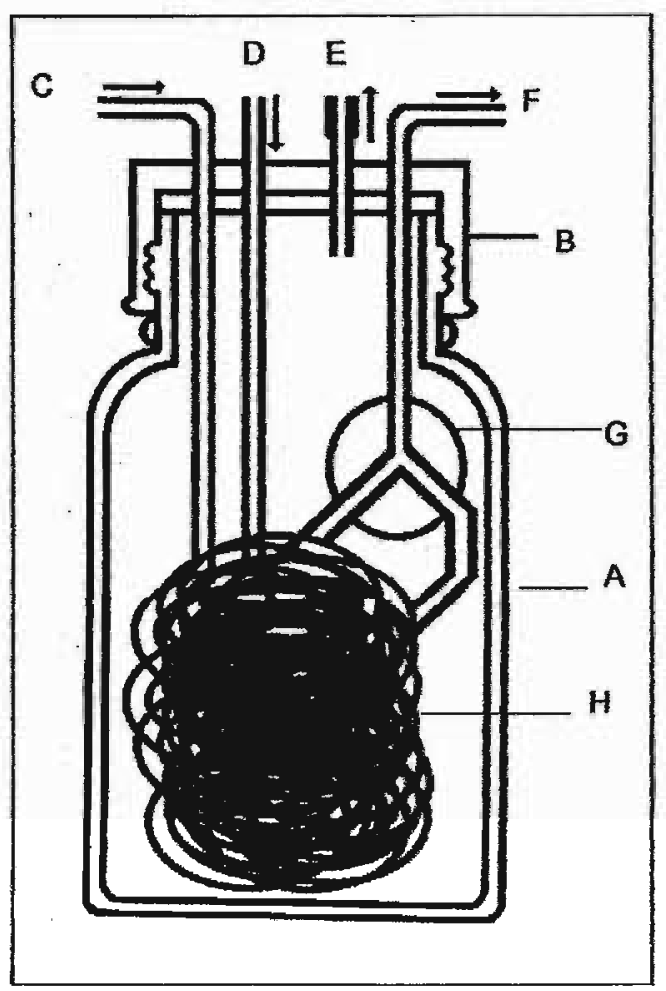

Figura 5.5.1 - Desoxigenador com duplo fluxo: A - frasco de vidro; B - tampa do frasco; C e D - entrada de soluções; E - conexão para bomba de vácuo; F saída de soluções; $G$ - dispositivo de acrílico para convergência das linhas e $H$ - tubos de silicone. 


\subsection{SISTEMA FIA PARA DETECÇÃO DE $\mathrm{H}_{2} \mathrm{O}_{2}$ NA FASE GASOSA DA ATMOSFERA UTILIZANDO COLETOR POR DIFUSÃO}

O sistema FIA para determinação de peróxido apresenta duas vias de fluxo, sendo uma para o eletrólito suporte e outra para o transportador. O eletrólito suporte utilizado é $\mathrm{NaOH}\left(11 \mathrm{mmol} \mathrm{L}^{-1}\right)$, obtido por mistura de $\mathrm{NaOH}\left(90 \mathrm{mmol} \mathrm{L}^{-1}\right)$ sob vazão de $0,15 \mathrm{~mL} \mathrm{~min}^{-1}$ com água deionizada a uma vazão de $1,1 \mathrm{~mL} \mathrm{~min}^{-1}$, fícando o $\mathrm{pH}$ em torno de 12 após a junção das duas vias (Figura 5.6.1).

$\mathrm{O}$ potencial de trabalho escolhido foi $-0,07 \mathrm{~V}$ vs $\mathrm{Ag} / \mathrm{AgCl}$, potencial em que a interferência do oxigênio é mínima, permitindo a detecção amperométrica da oxidação do $\mathrm{H}_{2} \mathrm{O}_{2}$. Por o sistema operar em meio alcalino, ocorre antecipação da oxidação do mercúrio para próximo de $-0,02 \mathrm{~V}$. Por outro lado, a corrente de redução do oxigênio atinge o valor limite a $-0,1 \mathrm{~V}$; portanto, a faixa de potencial de trabalho é bem estreita nestas condições. Para proporcionar maior estabilidade e aumento da faixa de trabalho o oxigênio foi retirado do sistema utilizando o desoxigenador, descrito anteriormente. 


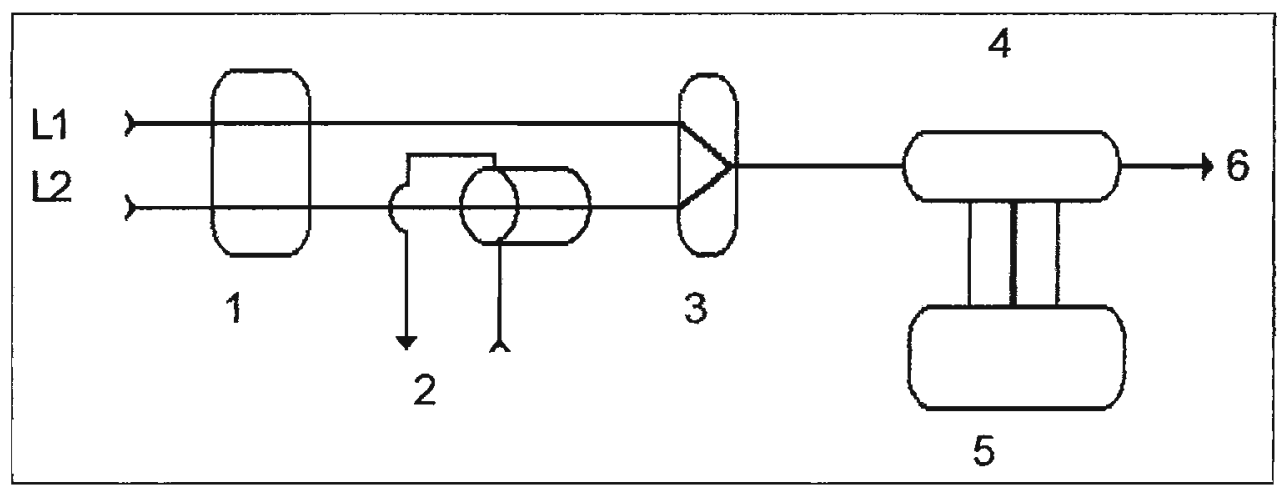

Figura 5.6.1 Esquema de sistema FIA para análise de $\mathrm{H}_{2} \mathrm{O}_{2}$ 1- Bomba peristáltica; 2- Injetor/Comutador; 3- Desoxigenador; 4- Célula eletroquímica; 5- Potenciostato/Registrador; 6- Descarte L1- Linha para fluxo de eletrólito suporte L2- Linha de fluxo para transportador.

$\mathrm{O}$ novo sistema de coleta desenvolvido para $\mathrm{H}_{2} \mathrm{O}_{2}$ no ar, descrito no item 5.2 deste Capítulo, foi interligado diretamente ao sistema FIA, acima descrito, mediante alimentação da alça de amostragem de $300 \mu \mathrm{L}$, como mostra a Figura 5.6.2. Esse arranjo é susceptível de automação, possibilitando o monitoramento com resolução de 1 ou 2 horas. A Figura 5.6.3 mostra a dimensão real de todo o sistema em operação. 


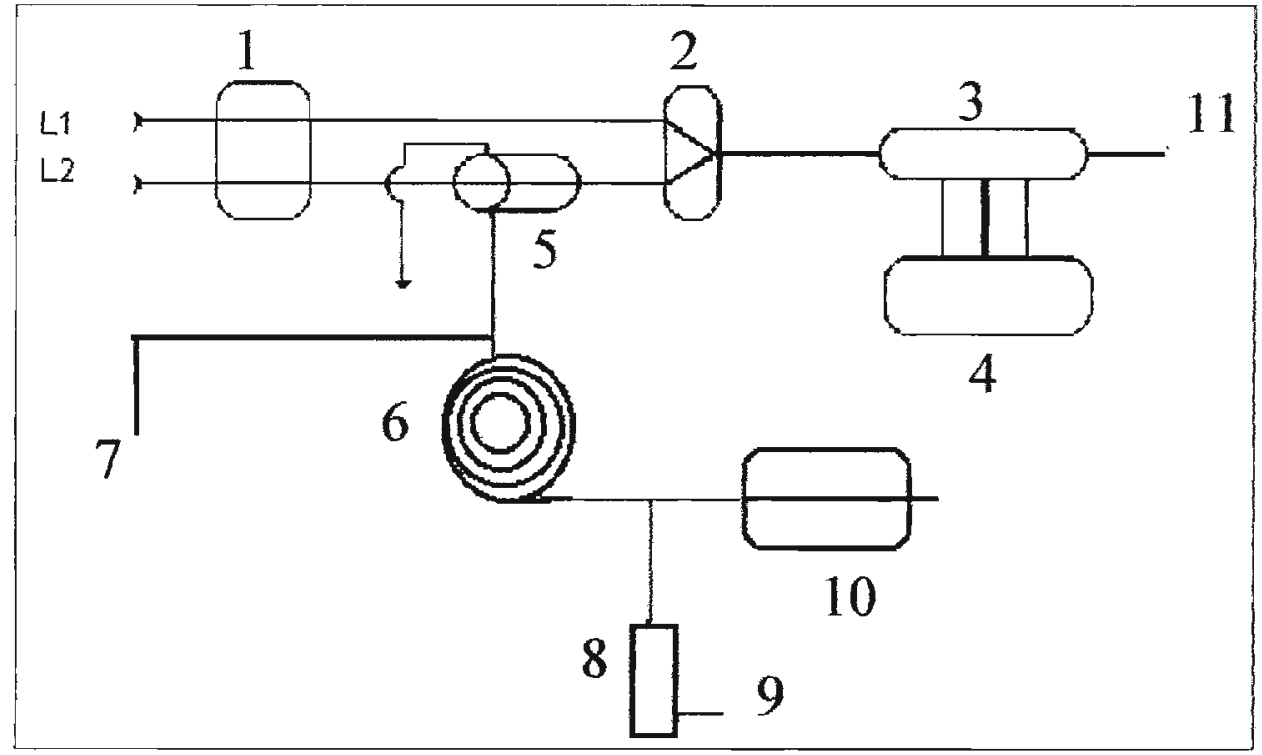

Figura 5.6.2 Sistema FIA para detecção de $\mathrm{H}_{2} \mathrm{O}_{2}$ conectado a coletor por difusão $\left(\mathrm{Oxyphan}^{(\mathrm{B})}\right.$ ): 1- Bomba peristáltica; 2- Desoxigenador; 3- Célula eletroquímica; 4- Potenciostato; 5- Injetor; 6- Coletor por difusão; 7- Entrada de ar; 8- Bomba de aquário; 9- Saída de ar; 10- Bomba peristáltica; 11Descarte.

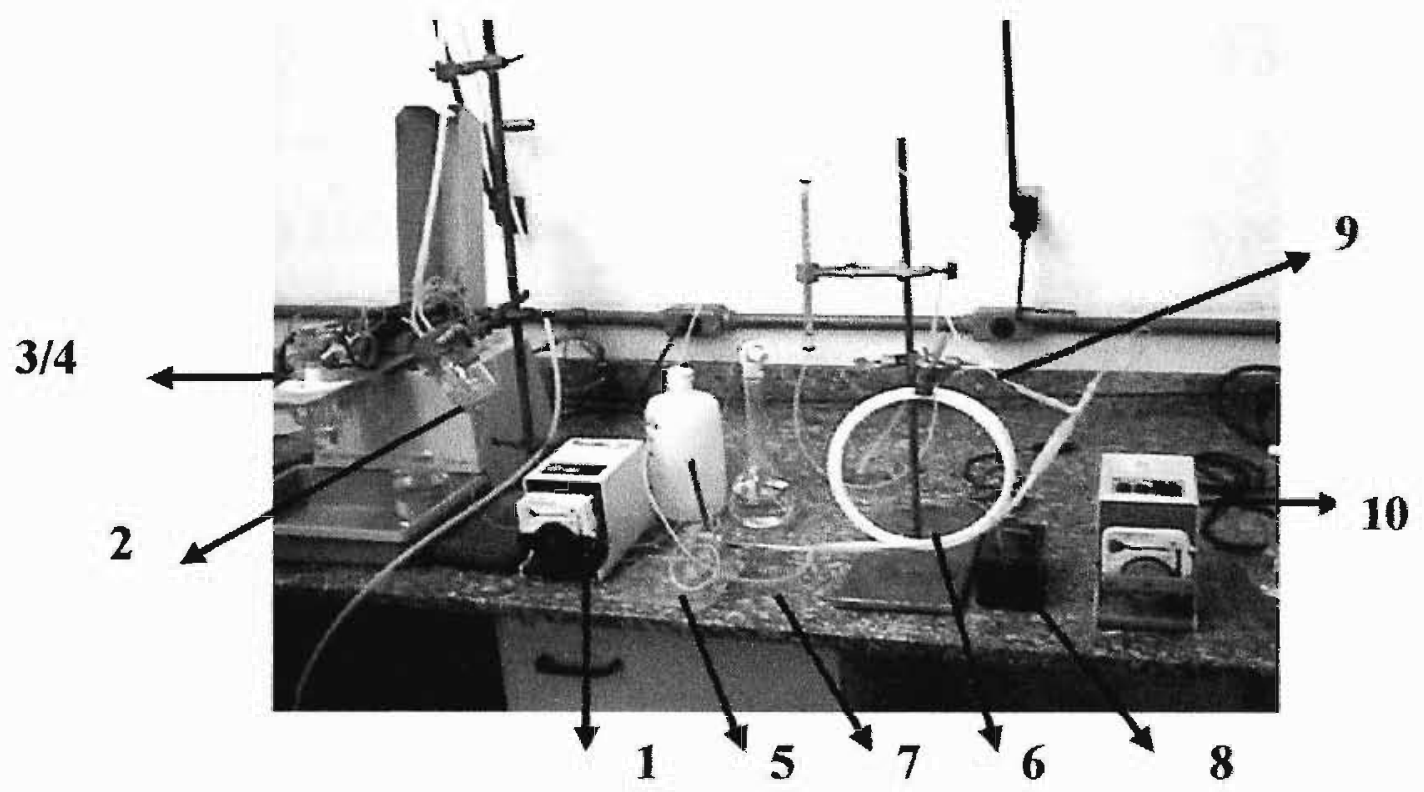

Figura 5.6.3 Foto do sistema FIA para análise de $\mathrm{H}_{2} \mathrm{O}_{2}$ coletado por difusão 


\subsection{USO DA CATALASE PARA CONFERIR SELETIVIDADE AO SINAL AMPEROMÉTRICO}

Para determinar seletivamente $\mathrm{H}_{2} \mathrm{O}_{2}$, recorreu-se a medidas diferenciais envolvendo exposição alternada à enzima catalase; ou seja, injeta-se uma alíquota de amostra coletada no sistema em fluxo; em seguida, injeta-se outra alíquota acrescida de catalase. A diferença entre os sinais amperométricos será proporcional à concentração de $\mathrm{H}_{2} \mathrm{O}_{2}$ na amostra, conforme anteriormente praticado na amperometria com eletrodo de platina (Gutz et al., 1989).

Inicialmente, uma alíquota da amostra é injetada no sistema, onde será registrado o sinal amperométrico. Uma segunda alíquota da amostra de chuva é exposta à enzima catalase antes de ser alcalinizada, uma vez que a atividade catalítica da enzima catalase é mais intensa na região próxima a neutralidade. Posteriormente, a alíquota é injetada na célula eletroquímica. $O$ pequeno sinal amperométrico obtido corresponde a processos de oxidação, porém sem a participação do $\mathrm{H}_{2} \mathrm{O}_{2}$. Portanto, a concentração de $\mathrm{H}_{2} \mathrm{O}_{2}$ será proporcional à diferença da altura dos picos nas amostras, com e sem catalase. A Figura 5.7.1 exemplifica o uso da catalase como medidas diferenciais

Foi observado que a quantidade necessária de catalase para a destruição do $\mathrm{H}_{2} \mathrm{O}_{2}$ e sem provocar interferências nos sinais amperométricos obtidos foi de $10 \mu \mathrm{L}$ de uma solução diluída 1:200, da enzima comercial catalase para 2 $\mathrm{mL}$ de amostra. 


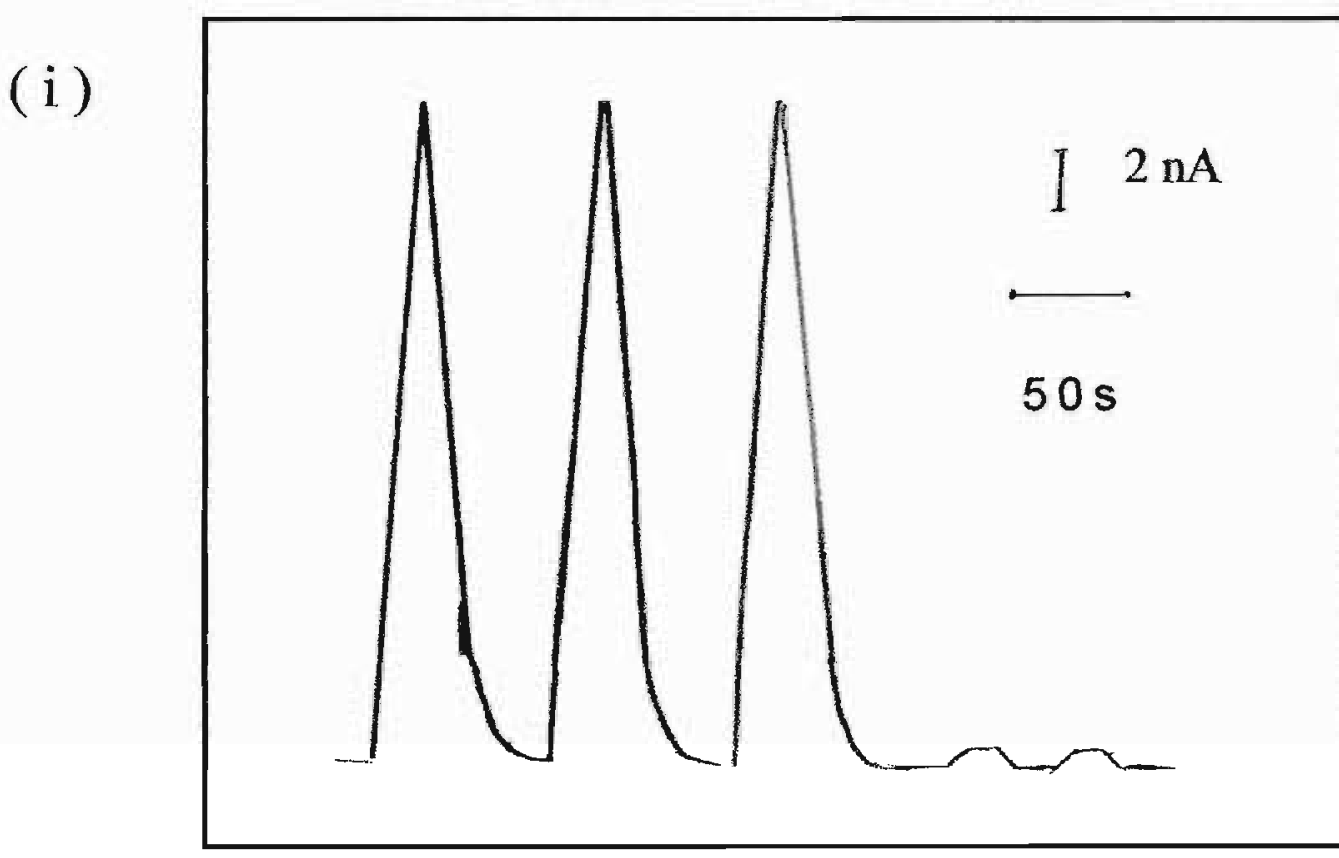

(t)

Figura 5.7.1 Sinais amperométricos de $\mathrm{H}_{2} \mathrm{O}_{2}$ de concentração $10 \mu \mathrm{mol} \mathrm{L}{ }^{-1}, 3$ picos antes e 2 após a exposição à enzima catalase. 


\subsection{RESULTADOS E DISCUSSÃO}

Para verificar a eficiência do método FIA-Amperométrico proposto foram feitas medições comparativas em colaboração com pesquisadores do mesmo grupo, os quais desenvolveram método FIA amperométrico com micro eletrodo de Au/Pt. Assim, efetuou-se intercomparaçãode 3 métodos, a saber, o sistema FIA desenvolvido nesta tese com eletrodo de gota pendente de mercúrio, o método espectrofotométrico (Bergmeyer, 1974) e outro amperométrico com micro eletrodo de Au/Pt (Matos et al. 2001).

Para esta intercomparação foram utilizadas amostras de água de chuva e determinadas as concentrações de $\mathrm{H}_{2} \mathrm{O}_{2}$. Na Tabela 5.8.1 é apresntada uma compilação dos dados obtidos pelos três métodos, publicada em artigo de Matos et al. (2001). A Figura 5.8.1 mostra a boa correlação entre o método analítico aqui exposto e os citados. 
Tabela 5.8.1 Determinação de $\mathrm{H}_{2} \mathrm{O}_{2}$ em água de chuva por método FIAAmperométrico com $\mathrm{HMDE}$, espectrofotométrico e amperométrico com eletrodo de Au/Pt. (Mattos et al., 2001).

\begin{tabular}{|c|c|c|c|}
\hline $\begin{array}{c}\text { Amostra De } \\
\text { Água De } \\
\text { Chuva }\end{array}$ & $\begin{array}{c}\text { HMDE } \\
\text { (Presente Trabalho) } \\
{\left[\mathrm{H}_{2} \mathrm{O}_{2}\right] \mu \mathrm{mol} \mathrm{L}^{-1}}\end{array}$ & $\begin{array}{c}\text { Método } \\
\text { Espectrofotométrico } \\
{\left[\mathrm{H}_{2} \mathrm{O}_{2}\right] \mu \mathrm{mol} \mathrm{L}^{-1}}\end{array}$ & $\begin{array}{c}\text { Au/Pt } \\
\text { Micro-Eletrodo } \\
{\left[\mathrm{H}_{2} \mathrm{O}_{2}\right] \mu \mathrm{mol} \mathrm{L}{ }^{-1}}\end{array}$ \\
\hline 1 & $1,87 \pm 0,02$ & $1,73 \pm 0,04$ & $1,68 \pm 0,04$ \\
\hline 2 & $1,80 \pm 0,01$ & $1,79 \pm 0,04$ & $1,77 \pm 0,03$ \\
\hline 3 & $4,78 \pm 0,04$ & $4,79 \pm 0,03$ & $4,78 \pm 0,04$ \\
\hline 4 & $3,59 \pm 0,07$ & $4,15 \pm 0,05$ & $4,23 \pm 0,08$ \\
\hline 5 & $3,53 \pm 0,07$ & $3,68 \pm 0,03$ & $3,86 \pm 0,04$ \\
\hline 6 & $3,95 \pm 0,06$ & $3,99 \pm 0,02$ & $4,05 \pm 0,05$ \\
\hline 7 & $3,17 \pm 0,09$ & $2,96 \pm 0,02$ & $2,83 \pm 0,05$ \\
\hline 8 & $31,6 \pm 0,3$ & $30,5 \pm 0,2$ & $29,5 \pm 0,4$ \\
\hline 9 & $16,4 \pm 0,2$ & $15,9 \pm 0,2$ & $16,9 \pm 0,4$ \\
\hline 10 & $21,2 \pm 0,5$ & $22,0 \pm 0,5$ & $22,4 \pm 0,1$ \\
\hline
\end{tabular}



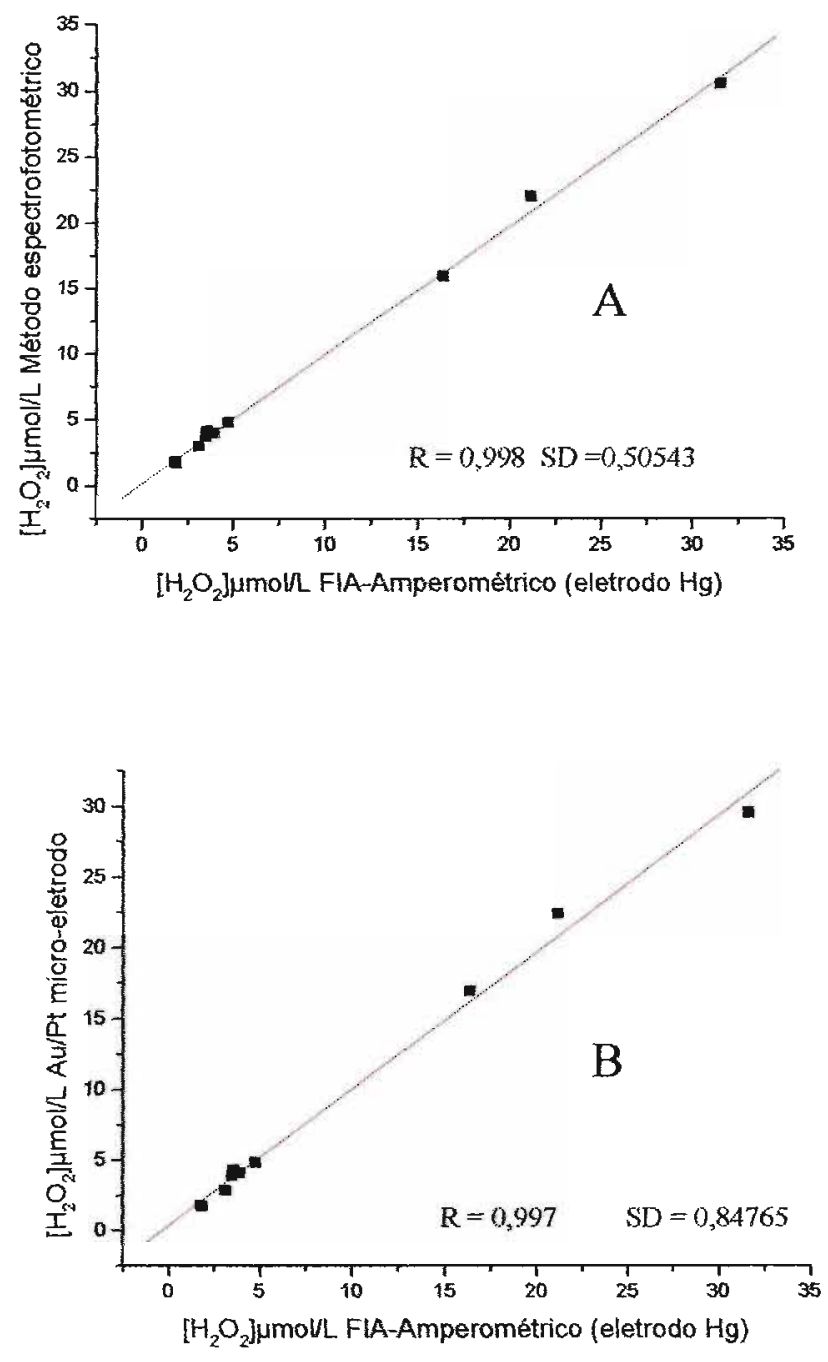

Figura 5.8.1 Correlação entre o método analítico FIA-Amperométrico com e (A) espectrofotométrico e (B) amperométrico com eletrodo de Au/Pt.

Como pode ser observado na Figura 5.8.1. o método FIAAmperométrico apresentou boa concordância com os métodos espectrofotométrico e amperométrico com eletrodo de Au/Pt. 
Uma vez desenvolvidos os métodos de coleta (por difusão e crioamostragem) e de determinação analítica (FIA-Amperométrico), amostras de ar foram coletadas utilizando-se os dois coletores simultaneamente e determinadas as concentrações de $\mathrm{H}_{2} \mathrm{O}_{2}$ para posterior comparação dos resultados. Coletas de $\mathrm{H}_{2} \mathrm{O}_{2}$ na fase gasosa da atmosfera foram efetuadas pelos dois sistemas de amostragem desenvolvidos nos dias 03 e 04 de outubro de 2000 , sem interrupção, a cada hora, e os resultados são reproduzidos nas Tabelas 5.8.2 e 5.8.3.

O método da crioamostragem baseia-se no fato experimental de que a razão $\mathrm{H}_{2} \mathrm{O}: \mathrm{H}_{2} \mathrm{O}_{2}$ da fase gasosa se mantém praticamente inalterada na fase sólida (gelo coletado) (Jacob et al., 1986). Desta forma, a coleta da umidade não precisa ser quantitativa, nem a vazão do ar precisa ser conhecida, necessitando-se apenas conhecer a umidade relativa e a temperatura para efetuar os cálculos de concentração na fase gasosa. Assim, efetuou-se as medições de temperatura (B) e umidade relativa (C) durante a amostragem criogênica, como mostra a Tabela 5.8.2. A partir da massa de vapor de água

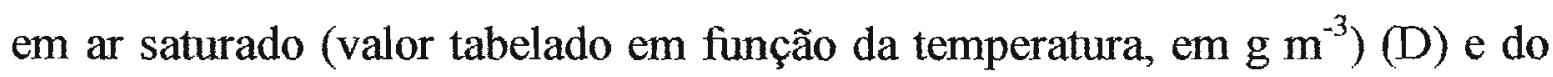
valor da umidade relativa medida obtem-se a concentração de vapor de água $\left(\mathrm{g} \mathrm{m}^{-3}\right)(\mathrm{E})$ para cada amostra.

Resumidamente, o amostrador criogênico coleta uma fração indeterminada do teor total de vapor de água contido no volume de ar também indeterminado que circulou pelo crioamostrador em uma hora. A concentração de $\mathrm{H}_{2} \mathrm{O}_{2}$ (F) é determinada pelo método FIA-Amperométrico descrito. Em seguida, a concentração de $\mathrm{H}_{2} \mathrm{O}_{2}$ em mol m $\mathrm{m}^{-3}$ é calculada multiplicando o valor de $(\mathrm{F})$ em mol $\mathrm{L}^{-1}$ por $10^{6} \mathrm{e}$ por $(\mathrm{E}) \mathrm{em} \mathrm{g} \mathrm{m}^{-3}$, pois $\mathrm{g} \mathrm{m}^{-3} \cong 10^{-6} \mathrm{~L}_{(\mathrm{l})} / \mathrm{L}_{(\mathrm{g})}$. Os valores encontrados encontram-se na coluna $(\mathrm{G}) \mathrm{da}$ Tabela 5.8.2. 
Tabela 5.8.2 Crioamostragem de $\mathrm{H}_{2} \mathrm{O}_{2}$ na atmosfera nos dias 03 e 04 de outubro de 2000 . A- Horário de coleta, B-temperatura, C- umidade relativa, $\mathrm{D}$ - massa de vapor de água em ar saturado $\left(\mathrm{g} \mathrm{m}^{-3}\right)$, E- massa relativa de vapor de água $\left(\mathrm{g} \mathrm{m}^{-3} \cong \mu \mathrm{L}_{(\mathrm{l})} / \mathrm{L}_{(\mathrm{g})}\right)$, F- concentração de $\mathrm{H}_{2} \mathrm{O}_{2}$ na solução de coleta ( $\mu \mathrm{mol} \mathrm{L}{ }^{-1}$ ), G- concentração de $\mathrm{H}_{2} \mathrm{O}_{2}$ na atmosfera $\left(\mathrm{pmol} \mathrm{L}^{-1}\right.$ ).

\begin{tabular}{|c|c|c|c|c|c|c|}
\hline $\begin{array}{c}\text { Horário } \\
\text { Coleta } \\
\text { (A) }\end{array}$ & $\begin{array}{l}\text { Temp. } \\
\left({ }^{\circ} \mathrm{C}\right) \\
(\mathrm{B})\end{array}$ & $\begin{array}{c}\text { Umidade } \\
\text { Relativa } \\
\text { (C) }\end{array}$ & $\begin{array}{c}\mathbf{H}_{2} \mathbf{O}_{(\mathbf{g})} \\
\text { (D) }\end{array}$ & $\begin{array}{c}\mathbf{H}_{2} \mathbf{O}_{(\mathrm{g})} \\
(\mathrm{E})\end{array}$ & $\begin{array}{c}{\left[\mathrm{H}_{2} \mathrm{O}_{2}\right]} \\
(\mathbf{F})\end{array}$ & $\begin{array}{c}{\left[\mathrm{H}_{2} \mathrm{O}_{2}\right]} \\
\quad(\mathrm{G})\end{array}$ \\
\hline $10: 00 \mathrm{~h}$ & 22 & 55 & 16,69 & 10,8 & 1,0 & 11,0 \\
\hline $11: 00 \mathrm{~h}$ & 25 & 57 & 23,78 & 13,5 & 1,8 & 24,0 \\
\hline $12: 00 \mathrm{~h}$ & 25 & 55 & 23,78 & 13,1 & 3,6 & 47,0 \\
\hline $13: 00 \mathrm{~h}$ & 25 & 50 & 22,34 & 11,9 & 3,4 & 40,0 \\
\hline $14: 00 \mathrm{~h}$ & 24 & 50 & 23,78 & 11,2 & 3,7 & 41,0 \\
\hline $15: 00 \mathrm{~h}$ & 25 & 50 & 23,78 & 11,9 & 3,7 & 44,0 \\
\hline $16: 00 \mathrm{~h}$ & 24 & 46 & 22,34 & 10,3 & 3,9 & 40,0 \\
\hline $17: 00 \mathrm{~h}$ & 24 & 46 & 22,34 & 10,3 & 4,2 & 43,0 \\
\hline $18: 00 \mathrm{~h}$ & 24 & 46 & 22,34 & 10,3 & 3,9 & 40,0 \\
\hline $19: 00 \mathrm{~h}$ & 24 & 46 & 22,34 & 10,3 & 3,5 & 36,0 \\
\hline $20: 00 \mathrm{~h}$ & 23 & 50 & 20,98 & 10,5 & 1,8 & 19,0 \\
\hline $21: 00 \mathrm{~h}$ & 23 & 50 & 20,98 & 10,5 & 1,1 & 11,0 \\
\hline $22: 00 \mathrm{~h}$ & 21 & 55 & 18,45 & 10,1 & 1,1 & 11,0 \\
\hline $23: 00 \mathrm{~h}$ & 22 & 59 & 19,69 & 11,6 & 1,2 & 14,0 \\
\hline $24: 00 \mathrm{~h}$ & 21 & 60 & 18,45 & 11,1 & 1,5 & 17,0 \\
\hline 01:00h & 21 & 63 & 18,45 & 11,6 & 1,9 & 22,0 \\
\hline $02: 00 \mathrm{~h}$ & 21 & 64 & 18,45 & 11,8 & 1,8 & 21,0 \\
\hline 03:00h & 20 & 68 & 17,3 & 11,8 & 1,2 & 14,0 \\
\hline $04: 00 \mathrm{~h}$ & 19 & 75 & 16,2 & 12,1 & 0,8 & 9,7 \\
\hline $05: 00 \mathrm{~h}$ & 18 & 80 & 15,17 & 12,1 & 0,9 & 11,0 \\
\hline $06: 00 \mathrm{~h}$ & 13 & 85 & 11,59 & 9,8 & 0,6 & 5,9 \\
\hline $07: 00 \mathrm{~h}$ & 19 & 84 & 16,2 & 13,6 & 0,7 & 9,5 \\
\hline 08:00h & 19 & 84 & 16,2 & 13,6 & 0,7 & 9,5 \\
\hline
\end{tabular}


Tabela 5.8.3 Coleta por difusão com membranas micro porosas para $\mathrm{H}_{2} \mathrm{O}_{2}$ na atmosfera nos dias 03 e 04 de outubro de 2000. A- Horário de coleta, Btemperatura, C- umidade relativa, D- volume de ar aspirado (L), Econcentração $\left(\mu \mathrm{mol} \mathrm{L} \mathrm{L}^{-1}\right.$ ) de $\mathrm{H}_{2} \mathrm{O}_{2}$ em $1,2 \mathrm{~mL}$ de solução de coleta, Fconcentração de $\mathrm{H}_{2} \mathrm{O}_{2}$ na atmosfera (pmol L $\left.{ }^{-1}\right)$.

\begin{tabular}{|c|c|c|c|c|c|}
\hline $\begin{array}{c}\text { Horário } \\
\text { Coleta } \\
\text { (A) }\end{array}$ & $\begin{array}{l}\text { Temp. } \\
\left({ }^{\circ} \mathrm{C}\right) \\
(\mathrm{B})\end{array}$ & $\begin{array}{c}\text { Umidade } \\
\text { Relativa } \\
\text { (C) }\end{array}$ & $\begin{array}{l}\text { Vol. Ar } \\
\text { (D) }\end{array}$ & $\begin{array}{c}{\left[\mathrm{H}_{2} \mathrm{O}_{2}\right]} \\
(\mathrm{E})\end{array}$ & $\begin{array}{c}{\left[\mathrm{H}_{2} \mathrm{O}_{2}\right]} \\
(\mathrm{F})\end{array}$ \\
\hline $10: 00 \mathrm{~h}$ & 22 & 55 & 22,5 & 0,4 & 21 \\
\hline 11:00h & 25 & 57 & 22,5 & 1,0 & 53 \\
\hline $12: 00 \mathrm{~h}$ & 25 & 55 & 22,5 & 1,1 & 58 \\
\hline $13: 00 \mathrm{~h}$ & 25 & 50 & 22,5 & 1,1 & 58 \\
\hline $14: 00 \mathrm{~h}$ & 24 & 50 & 22,5 & 1,0 & 53 \\
\hline $15: 00 \mathrm{~h}$ & 25 & 50 & 22,5 & 0,9 & 48 \\
\hline $16: 00 \mathrm{~h}$ & 24 & 46 & 22,5 & 1,1 & 58 \\
\hline $17: 00 \mathrm{~h}$ & 24 & 46 & 22,5 & 1,0 & 53 \\
\hline $18: 00 \mathrm{~h}$ & 24 & 46 & 22,5 & 0,8 & 42 \\
\hline $19: 00 \mathrm{~h}$ & 24 & 46 & 22,5 & 0,6 & 32 \\
\hline $20: 00 \mathrm{~h}$ & 23 & 50 & 22,5 & 0,4 & 21 \\
\hline $21: 00 \mathrm{~h}$ & 23 & 50 & 22,5 & 0,3 & 16 \\
\hline $22: 00 \mathrm{~h}$ & 21 & 55 & 22,5 & 0,3 & 16 \\
\hline $23: 00 \mathrm{~h}$ & 22 & 59 & 22,5 & 0,3 & 16 \\
\hline $24: 00 \mathrm{~h}$ & 21 & 60 & 22,5 & 0,5 & 26 \\
\hline 01:00h & 21 & 63 & 22,5 & 0,4 & 21 \\
\hline $02: 00 \mathrm{~h}$ & 21 & 64 & 22,5 & 0,5 & 26 \\
\hline $03: 00 \mathrm{~h}$ & 20 & 68 & 22,5 & 0,4 & 21 \\
\hline $04: 00 \mathrm{~h}$ & 19 & 75 & 22,5 & 0,4 & 21 \\
\hline $05: 00 \mathrm{~h}$ & 18 & 80 & 22,5 & 0,3 & 16 \\
\hline $06: 00 \mathrm{~h}$ & 13 & 85 & 22,5 & 0,3 & 16 \\
\hline $07: 00 \mathrm{~h}$ & 19 & 84 & 22,5 & 0,3 & 16 \\
\hline $08: 00 \mathrm{~h}$ & 19 & 84 & 22,5 & 0,4 & 21 \\
\hline
\end{tabular}


$\mathrm{Na}$ coleta por difusão o fluxo de água deionizada (utilizada como líquido coletor) dentro do feixe foi mantido sob vazão de $20 \mu \mathrm{L}$ min $^{-1}$, obtendo-se um volume de $1,2 \mathrm{~mL}$ de amostra por hora (desprezadas perdas por evaporação). $\mathrm{O}$ volume de ar aspirado pelo tubo de difusão gasosa foi de $22,5 \mathrm{~L} \mathrm{~h}^{-1}$ (D), aproximadamente um mol de ar por hora (depende da temperatura e da pressão atmosférica) (Tabela 5.8.2). As amostras foram injetas "on-line" no sistema FIA e determinadas as concentrações de $\mathrm{H}_{2} \mathrm{O}_{2}$ na solução coletora (E). Admitindo $100 \%$ de eficiência na coleta, tem-se que o produto da concentração de $\mathrm{H}_{2} \mathrm{O}_{2}$ encontrada pelo volume coletado, $1,2.10^{-3} \mathrm{~L}$, corresponde ao número de mols de $\mathrm{H}_{2} \mathrm{O}_{2}$ em $22,5 \mathrm{~L}$.

A concentração média de $\mathrm{H}_{2} \mathrm{O}_{2}$ com a crioamostragem foi de $24 \mathrm{pmol} \mathrm{L}^{-1}$ e por amostragem com membrana foi de $32 \mathrm{pmol} \mathrm{L}^{-1}$. Por motivos operacionais as coletas não foram feitas no mesmo laboratório do IQ-USP, mas laboratórios próximos no Bloco 12, aspirando ar diretamente pela janela numa altura aproximada de 10 metros do solo. Este pode ter sido um fator a contribuir para a diferença observada, de $25 \%$ entre as concentrações de $\mathrm{H}_{2} \mathrm{O}_{2}$ encontradas pelas duas técnicas de coleta. Outro fator, talvez mais importante, foi o de não se ter levado em conta as perdas de água por evaporação na superfície externa dos filamentos durante a amostragem. No estudo da amostragem de $\mathrm{CH}_{2} \mathrm{O}$, feito num período muito seco (ver tabela 4.1.6.1), tomou-se este cuidado e as diferenças entre o volume introduzido e retirado dos capilares chegava a cair à metade nos piores casos. Não há dificuldades em introduzir este refinamento em futuras aplicações do método pois o líquido efluente pode ser coletado na saída da alça de amostragem e pesado ou medido com uma pipeta a cada hora.

A Figura 5.8.2 mostra $\mathrm{o}$ mesmo andamento da variação da concentração de $\mathrm{H}_{2} \mathrm{O}_{2}$ no ar pelos dois métodos de coleta, indicando boa 
correlação, comprovada na Figura 5.8.3 que poderia apresentar similaridade ainda melhor nos resultados obtidos se tivesse sido levada em conta a evaporação. Isto porque, quando a mesma quantidade de $\mathrm{H}_{2} \mathrm{O}_{2}$ é coletada num volume maior, a concentração determinada é maior, tal como se observa na Figura 5.8.2.

$\mathrm{O}$ perfil das variações nas concentrações de $\mathrm{H}_{2} \mathrm{O}_{2}$ ao longo do dia mostrou-se semelhante aos encontrados na literatura, como por exemplo, Manahan (1999) (Figura 1.2.1). O peróxido de hidrogênio, por ser uma espécie formada fotoquimicamente, apresenta concentrações maiores no período de 12:00 h às 16:00 h, quando a incidência solar é maior, decrescendo durante a noite, quando o seu consumo prevalece sobre a formação.

Todavia, por volta das $24: 00 \mathrm{~h}$ do período de amostragem, a concentração de $\mathrm{H}_{2} \mathrm{O}_{2}$ voltou a elevar-se de modo perceptivel, para decair novamente entre as 02:00 h e o amanhecer $(06: 00 \mathrm{~h})$, quando volta a crescer. 


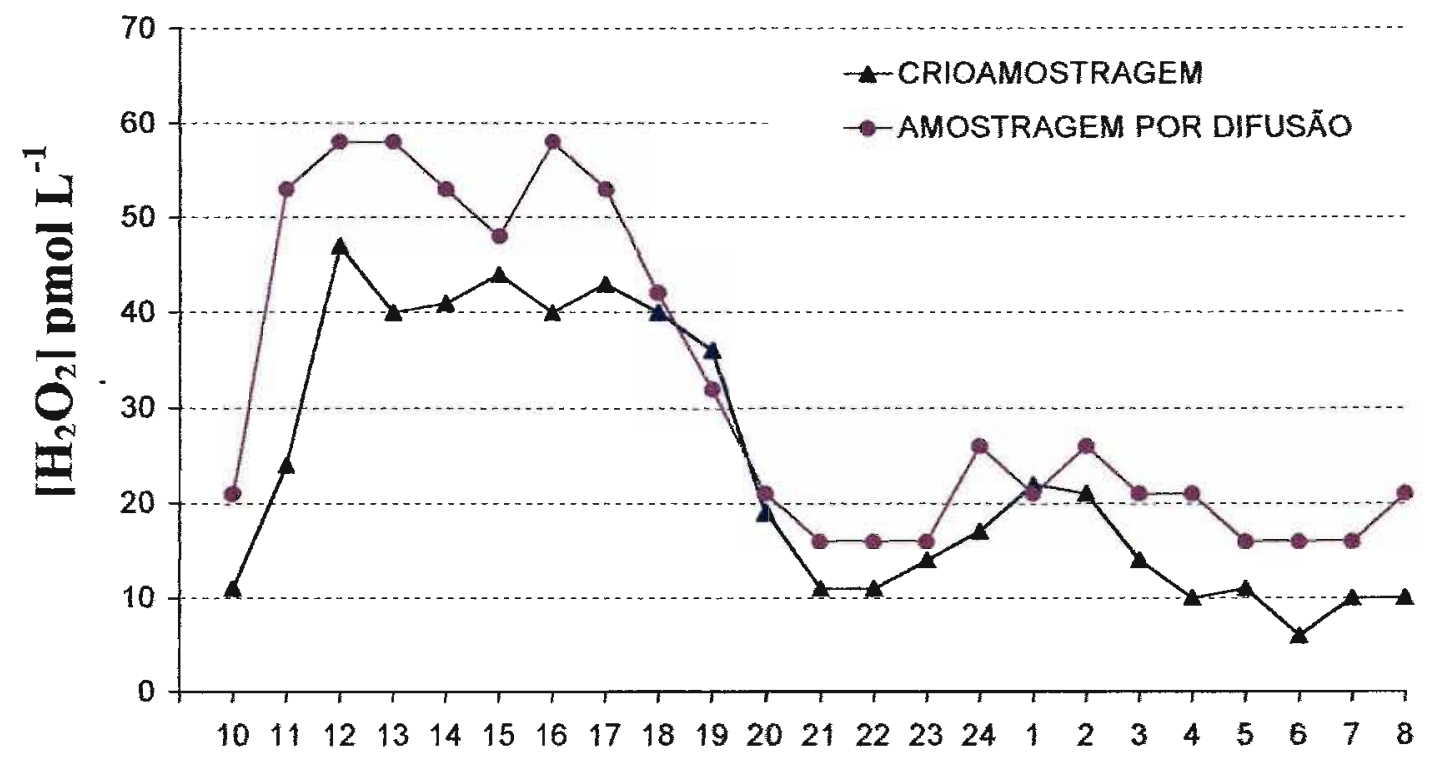

Hora do dia

Figura 5.8.2 Comparação das análises de $\mathrm{H}_{2} \mathrm{O}_{2}$ obtidas por amostragem criogênica e por difusão em amostras ambientais por período consecutivo de $24 \mathrm{~h}$. 


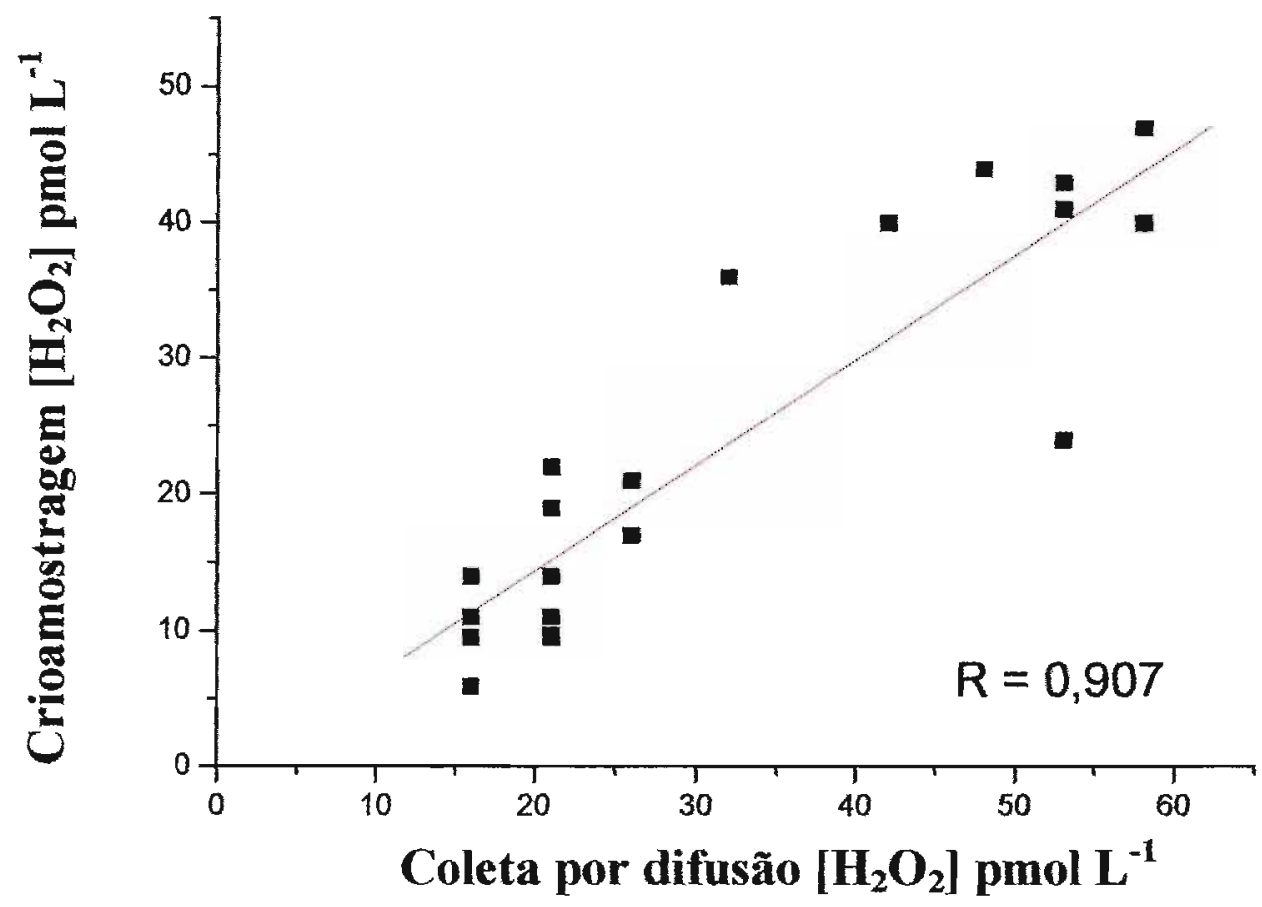

Figura 5.8.3 Correlação entre amostragem por difusão e criogênica de $\mathrm{H}_{2} \mathrm{O}_{2}$ em amostras ambientais por $24 \mathrm{~h}$ consecutivas

Tabela 5.8.4, comparam-se as a faixa de concentrações das amostras de $\mathrm{H}_{2} \mathrm{O}_{2}$ registradas em São Paulo no curto período relatado com as obtidas em várias localidades do mundo (Lee et al., 2000). Como se verifica, os valores encontrados não destoam dos observados em outras regiões urbanas ou remotas. 
Cabe ressaltar que para amostras reais efetuou-se testes para verificar a eficiência da coleta. Assim, dois coletores por difusão foram colocados em série, de maneira que o ar aspirado atravessasse os dois coletores. Em seguida, as amostras foram analisadas pelo sistema FIA-Amperométrico, descrito acima, constatando-se a ausência de sinal amperométrico no segundo coletor.

O sistema FIA amperométrico desenvolvido mostrou-se eficaz para análise de $\mathrm{H}_{2} \mathrm{O}_{2}$ em amostras ambientais nas fases gasosa e líquida da atmosfera, alcançando o limite de detecção de $0,1 \mu \mathrm{mol} \mathrm{L}^{-1}$, após préconcentração. Além da boa correlação frente a outros métodos de determinação, já comprovada na Tabela 5.8.1, o método apresenta grande vantagem frente aos eletrodos sólidos, qual seja, basta apertar um botão para renovar a gota de mercúrio quando esta ficar contaminada; já os eletrodos sólidos necessitam de polimento ou reativação eletroquímica periódica quando se trabalha com amostras muito poluídas.

O crioamostrador passivo desenvolvido mostrou-se de fácil manejo, baixo custo e apropriado para coletas em campo, por não depender de energia elétrica (requerendo, contudo, um estoque de gelo seco). Ainda, como o coletor criogênico desenvolvido opera em temperaturas próxima a $-70^{\circ} \mathrm{C}$, minimiza o efeito de interferentes, como discutido no item 5.1

$\mathrm{O}$ acoplamento do dispositivo de coleta de $\mathrm{H}_{2} \mathrm{O}_{2}$ por difusão através de tubos capilares ocos de polipropileno (Oxyphan ${ }^{(B)}$ ) com o detetor em fluxo permite a injeção periódica de amostras (on-line) sem que haja necessidade de manipulações laboriosas, possibilitando a automação do sistema e evitando armazenamento com risco de decomposição do analito. 
Tabela 5.8.4 Medidas de $\mathrm{H}_{2} \mathrm{O}_{2}$ na fase gasosa da atmosfera em várias localidades utilizando-se diversos métodos de amostragem e análise (Lee et al., 2000).

\begin{tabular}{|c|c|c|c|c|c|}
\hline Autor & Data & Local & $\begin{array}{c}\text { Método De } \\
\text { Coleta }\end{array}$ & Método Analítico & {$\left[\mathrm{H}_{2} \mathrm{O}_{2}\right] p p b v$} \\
\hline Esta Tese & 2003 & $\begin{array}{l}\text { São Paulo } \\
\text { USP }\end{array}$ & Tubo de difusão & $\begin{array}{c}\text { FIA-Amperométrico } \\
\text { com HMDE }\end{array}$ & $0,38-1,39$ \\
\hline Esta Tese & 2003 & $\begin{array}{l}\text { São Paulo } \\
\text { USP }\end{array}$ & $\begin{array}{c}\text { Crioamostragem } \\
-70^{\circ} \mathrm{C}\end{array}$ & $\begin{array}{l}\text { FIA-Amperométrico } \\
\text { com HMDE }\end{array}$ & $0,14-1,13$ \\
\hline $\begin{array}{l}\text { Heikes et } \\
\text { al. (1988) }\end{array}$ & 1986 & $\begin{array}{l}\text { Atlântico } \\
\text { Oeste }\end{array}$ & $\begin{array}{l}\text { Tubo coletor } \\
\text { espiralado }\end{array}$ & $\begin{array}{c}\text { Fluorescência } \\
\text { enzimática }\end{array}$ & $0,05-1,24$ \\
\hline $\begin{array}{c}\text { Slemr et at. } \\
\text { (1986) }\end{array}$ & $\begin{array}{l}1984 \\
1985\end{array}$ & Ontario & & TDLAS & $0,3-2,1$ \\
\hline $\begin{array}{l}\text { Tanner et } \\
\text { al. }(1986)\end{array}$ & 1985 & $\begin{array}{c}\text { Brookhaven } \\
\text { National }\end{array}$ & $\begin{array}{l}\text { "impinger" e } \\
\text { difusional }\end{array}$ & Fluorescência & $0,1-2,0$ \\
\hline $\begin{array}{l}\text { Dollard et } \\
\text { al. }(1989)\end{array}$ & 1987 & Inglaterra & $\begin{array}{c}\text { Tubo coletor } \\
\text { espiralado }\end{array}$ & Quimioluminescência & $0,03-1,65$ \\
\hline $\begin{array}{c}\text { Sakugawa e } \\
\text { Kaplan } \\
(1989)\end{array}$ & $\begin{array}{c}1985- \\
1988\end{array}$ & Los Angeles & $\begin{array}{c}\text { Crioamostragem } \\
-60^{\circ} \mathrm{C}\end{array}$ & $\begin{array}{l}\text { Fluorescência } \\
\text { enzimática }\end{array}$ & $0,03-2,04$ \\
\hline $\begin{array}{c}\text { Dasgupta et } \\
\text { al. }(1990)\end{array}$ & 1986 & Califórnia & $\begin{array}{l}\text { Tubo coletor } \\
\text { espiralado }\end{array}$ & $\begin{array}{l}\text { Fluorescência } \\
\text { enzimática }\end{array}$ & $0,1-3,1$ \\
\hline $\begin{array}{l}\text { Jacob et al. } \\
\quad(1990)\end{array}$ & 1988 & Brasil & $\begin{array}{c}\text { Crioamostragem } \\
-45^{\circ} \mathrm{C}\end{array}$ & $\begin{array}{l}\text { Quimioluminescência } \\
\text { (TCPO) }\end{array}$ & $0,2-3,9$ \\
\hline $\begin{array}{l}\text { Dommen et } \\
\text { al. (1995) }\end{array}$ & $\begin{array}{l}1990- \\
1991\end{array}$ & Suíça & $\begin{array}{c}\text { Tubo coletor } \\
\text { espiralado }\end{array}$ & $\begin{array}{c}\text { Fluorescência } \\
\text { enzimática }\end{array}$ & $0,3-4,7$ \\
\hline $\begin{array}{c}\text { Tanner e } \\
\text { Schorran } \\
(1995)\end{array}$ & 1992 & $\begin{array}{l}\text { Meadview, } \\
\quad \text { AZ }\end{array}$ & $\begin{array}{l}\text { Tubo coletor } \\
\text { espiralado }\end{array}$ & $\begin{array}{l}\text { Fluorescência } \\
\text { enzimática }\end{array}$ & $1-4$ \\
\hline $\begin{array}{l}\text { Jacobe } \\
\text { Klockow } \\
(1992)\end{array}$ & 1988 & $\begin{array}{l}\text { Oceano } \\
\text { Atlântico }\end{array}$ & $\begin{array}{l}\text { Crioamostragem } \\
-45^{\circ} \mathrm{C}\end{array}$ & $\begin{array}{l}\text { Quimioluminescência } \\
\text { (TCPO) }\end{array}$ & $3-5$ \\
\hline $\begin{array}{c}\text { Weller e } \\
\text { Schrems } \\
(1993)\end{array}$ & $\begin{array}{l}1991- \\
1992\end{array}$ & $\begin{array}{l}\text { Oceano } \\
\text { Atlântico }\end{array}$ & $\begin{array}{l}\text { Tubo coletor } \\
\text { espiralado }\end{array}$ & $\begin{array}{l}\text { Fluorescência } \\
\text { enzimática }\end{array}$ & $0,05-1,80$ \\
\hline $\begin{array}{c}\text { Slemre } \\
\text { Tremmel } \\
(1994)\end{array}$ & 1990 & $\begin{array}{l}\text { Oceano } \\
\text { Atlântico }\end{array}$ & $\begin{array}{l}\text { Tubo coletor } \\
\text { espiralado }\end{array}$ & $\begin{array}{c}\text { Fluorescência } \\
\text { enzimática }\end{array}$ & $0,12-3,89$ \\
\hline $\begin{array}{l}\text { Martin et } \\
\text { al. (1997) }\end{array}$ & 1992 & $\begin{array}{l}\text { Atlântico } \\
\text { Norte }\end{array}$ & AEROLASER & $\begin{array}{l}\text { Fluorescência } \\
\text { enzimática }\end{array}$ & $0,65-1,5$ \\
\hline
\end{tabular}


CAPÍTULO VI - AVALIAÇÃo DA COMPOSIÇÃo IÔNICA DE ÁGUA DE CHUVA POR ELETROFORESE CAPILAR COM DETECÇÃO CONDUTOMÉTRICA SEM CONTATO 


\subsection{ASPECTOS GERAIS}

A deposição úmida é uma rota muito importante na remoção dos poluentes da atmosfera. Nas últimas décadas, a extensão e os impactos da chamada "chuva ácida" foram investigados completamente, especialmente no hemisfério norte. Estudos revelaram as conseqüências prejudiciais atribuídas ao impacto da deposição ácida nos ecossistemas terrestre e aquático e na corrosão e degradação dos edifícios e dos monumentos, os quais foram relatados de forma mais abrangente no Capítulo I desta tese.

Entretanto, cabe recordar que, considerando exclusivamente o equilíbrio com $\mathrm{CO}_{2}$ gasoso, a água de chuva deve apresentar um valor de $\mathrm{pH}$ em torno de 5,6. Valores mais baixos são causados principalmente pela presença dos ácidos sulfúrico, nítrico e carboxílicos; sendo seus principais precursores os óxidos do enxofre e do nitrogênio, hidrocarbonetos e compostos carbonílicos, envolvidos em reações complexas nas fases homogênea e heterogênea da atmosfera (Cowling, 1982; Gatz, 1991; Losno et al., 1991; Mage et al., 1996).

Para subsidiar pesquisas sobre a química da atmosfera e para a composição de bancos de dados, controle e avaliação da correlação com o impacto da deposição de poluentes pela fase líquida, redes de monitoramento foram estabelecidas, principalmente (mas não exclusivamente) em países desenvolvidos do hemisfério do norte. Estas redes confirmaram, como exemplo, as melhorias alcançadas com os programas de redução para emissões dos óxidos do enxofre, como conduzidos nos EUA e em parte da Europa, mostrando o declínio das concentrações de ácido sulfúrico na chuva, não acompanhado, contudo, ácido nítrico e de outros componentes ácidos (e básicos). 
No Brasil, o principal centro econômico é a região metropolitana de São Paulo, um dos maiores conglomerados humanos do mundo $(17,8$ milhões de habitantes, aproximadamente $10 \%$ da população nacional). Estima-se que 90\% das emissões antrópicas decorram da enorme frota de aproximadamente 6,0 milhões veículos automotores. A fração restante é emitida pela propagação de fontes estacionárias sobre a região, a mais densamente industrializada da América Latina, causando problemas severos de poluição do ar, tais como a formação de concentrações elevadas do "smog" fotoquímico de ozônio e $\mathrm{NO}_{\mathrm{x}}$, bem como o excesso de matéria particulada (CETESB, 2000; Mage et al., 1996).

Embora os principais poluentes do ar sejam monitorados regularmente desde 1973, somente em 1983 instalou-se uma rede automática de monitoramento. Porém, nenhum sistema similar foi desenvolvido para a deposição úmida. Dentre as possíveis razões pode-se citar: a caracterização química da água de chuva é mais laboriosa e dispendiosa, pois muitos analitos não podem ser determinados automaticamente nas estações da rede, os eventos da precipitação não põem em perigo a saúde humana diretamente e, de fato, as chuvas promovem benfazeja "limpeza" do ar atmosférico.

Assim, poucos estudos que tratam da composição química da água de chuva em São Paulo podem ser encontrados na literatura internacional (Forti et al. 1990; Fornaro et al., 1993; Paiva et al., 1997; Rocha et al., 2003; Fornaro et al., 2003).

A conversão das emissões veiculares no smog fotoquímico e/ou na fase líquida é, provavelmente, responsável pela maioria do ácido sulfúrico e nítrico encontrado na água de chuva, porém, necessita-se de uma investigação mais detalhada da deposição úmida local e da química da atmosfera.

Usualmente, o método padrão de análise para íons em amostras de água de chuva é a cromatografia de íons (CI) (Valsecchi et al., 1997). Nos últimos 
anos, a atenção foi estendida para a eletroforese capilar (CE) como uma ferramenta poderosa para a análise dos íons (Kaniansky et al., 1999; Pacáková et al., 1999; Fukushi et al., 1999). Em CE, as separações rápidas podem ser executadas com sensibilidade, boa seletividade, alta eficiência e baixo consumo de amostra e de reagentes.

Conseqüentemente, $\mathrm{CE}$ é uma potencial alternativa a $\mathrm{CI}$ para a análise de água de chuva e demonstrou-se que mesmo gotas de chuva ou o aerossol das nuvens podem ser analisados usando-se esta técnica (Bächmann e Tenberken, 1997 e 1996; Bächmann et al., 1997). A maioria dos compostos iônicos da deposição úmida não absorve a radiação na região UV ou visível do espectro. O esquema usual para análise destes íons é a deteç̧ão indireta UV ou do Vis, necessitando da adição de um cromóforo à solução tampão para originar picos negativos (diminuição da absorbância) durante a passagem da espécie não absorvente (Deng, 1998; Fung et al., 1998). Embora eficaz, este esquema resulta em limites de detecção menos favoráveis do que a deteç̧ão direta.

Entretanto, algumas vezes, torna-se vantajosa a derivatização dos analitos, como por exemplo, as hidrazonas de compostos carbonílicos que absorvem na região de UV-Visível (Bächmann et al., 1997). Quando aplicáveis, limites de detecção muito baixos podem ser alcançados com detecção de fluorescência induzida por laser (Bächmann et al., 1996).

A detecção eletroquímica ainda não foi investigada extensivamente em combinação com CE em amostras ambientais. Para alguns ânions, por exemplo, nitrito e sulfito, elevada sensibilidade e seletividade foram relatadas para deteç̧ão amperométrica (Bächmann et al., 1996). A detecção por condutividade (usada universalmente em combinação com $\mathrm{Cl}$ ) foi considerado para $\mathrm{CE}$ em análises de água de chuva pelo menos uma vez (Valsecchi et al., 1997). 
Em estudo comparativo de separação de ânions em água de chuva por $\mathrm{CI}$ e por $\mathrm{CE}$ usando a detecção condutométrica para ambas as técnicas, $\mathrm{CE}$ mostrou-se apropriada para esta finalidade e os resultados foram validados com materiais de referência padrão NIST 2694 I e II (Valsecchi et al., 1997).

A construção de detectores para $\mathrm{CE}$, seu acoplamento com o capilar e sua manutenção são, entretanto, mais trabalhosos do que para o $\mathrm{Cl}$, devido às dimensões reduzidas. Por outro lado, a interferência do elevado campo elétrico para separação dos analitos e os danos causados aos pequenos eletrodos expostos às amostras podem gerar problemas adicionais. Felizmente, aumentando-se a freqüência do sinal durante as medidas de condutividade (oscilometria), os eletrodos podem ser instalados fora do capilar, superando todos estes problemas. Fracassi et al. (1998) e Zemann et al. (1998), independentemente, propuseram e demonstraram esta modalidade de detecção condutométrica sem contato (CCD) (os primeiros autores com melhor relação de sinal/ruído) através do acoplamento dos dois eletrodos, em forma de anel, em torno do revestimento externo de poliimida do capilar fundido de sílica usado em CE.

A resposta deste detector condutométrico sem contato é essencialmente devido às diferenças da condutividade do eletrólito e do analito; conseqüentemente, é muito apropriado para as análises iônicas.

Neste trabalho, mostrar-se-á que CE-CCD pode ser vantajosamente aplicada à análise dos principais cátions como $\mathrm{Na}^{+}, \mathrm{Ca}^{2+}, \mathrm{K}^{+} \mathrm{e} \mathrm{NH}_{4}^{+}$, dos ânions inorgânicos como $\mathrm{SO}_{4}{ }^{2-}, \mathrm{NO}_{3}^{-} \mathrm{e} \mathrm{Cl}^{-} \mathrm{e}$ dos ânions orgânicos como $\mathrm{CH}_{3} \mathrm{O}^{-}$e $\mathrm{CH}_{3} \mathrm{CH}_{2} \mathrm{O}^{-}$em água de chuva, acelerando, simplificando e reduzindo o custo de estudos sistemáticos de deposição úmida, como provado durante a pesquisa empreendida na metrópole São Paulo.

Desta forma, desenvolveu-se novo método para a determinação mais fácil e menos dispendiosa dos constituintes químicos da fase líquida, 
objetivando avaliar a extensão e melhorar a compreensão da deposição úmida e da química da atmosfera na cidade de São Paulo.

\subsection{LOCAL DA AMOSTRAGEM DE ÁGUA DE CHUVA}

O local está aproximadamente a $46^{\circ} 43^{\circ} \mathrm{W}$ e $23^{\circ} 34^{\prime} \mathrm{S}$, a $750 \mathrm{~m}$ de altitude e aproximadamente $45 \mathrm{~km}$ da costa, bem dentro da cidade de São Paulo (10,5 milhões de habitantes), parte principal da região metropolitana (17,8 milhões de habitantes).

O clima da RMSP pode ser classificado como tropical de altitude, com inverno seco e frio, e verão quente e úmido. A precipitação é em torno de $1500 \mathrm{~mm}$, sendo que a maior parte ocorre nos meses de outubro a março. Nos meses de setembro a abril (verão quente $\mathrm{e}$ úmido) as condições meteorológicas são mais favoráveis à dispersão dos poluentes, por encontrarse a região sob grande instabilidade atmosférica que se forma em toda região Sudeste, e estão associadas a sistemas frontais vindo do sul do continente, da umidade proveniente da Região Amazônica e da brisa marítima.

Nos meses mais frios (maio a agosto) a região permanece com maior estabilidade devido à formação de altas pressões (anticiclone), ocasionando inversões térmicas nos baixos níveis da atmosfera, dificultando a dispersão dos poluentes.

\subsection{AMOSTRAGEM DE ÁGUA DE CHUVA}


As amostras de água de chuva foram coletadas no campus da Universidade de São Paulo, entre os períodos de maio/1997 e março/1998.

Para tanto, utilizou-se um coletor automático exclusivamente para deposição úmida, desenvolvido anteriormente dentro do mesmo grupo do orientador (Figura 6.3.1) (Fornaro et al., 1993).

O dispositivo de amostragem foi instalado num mastro cerca de $1,5 \mathrm{~m}$ acima do telhado do edifício do laboratório, aproximadamente $10 \mathrm{~m}$ acima do nível do solo. Um tubo de PTFE conduziu as amostras do coletor até o laboratório.

As amostras coletadas durante o período de maio/1997 a março/1998 foram compartilhadas com um estudo simultâneo de peróxido de hidrogênio, bissulfito e de hidroximetanossulfonato (HMS) por um novo método em fluxo amperométrico (Rocha, F.R., 1999). Devido à instabilidade mais elevada do $\mathrm{H}_{2} \mathrm{O}_{2}$ e do $\mathrm{HSO}_{3}^{-}$, as amostras foram congeladas pela exposição dos frascos plásticos ao gelo seco, posteriormente, foram armazenados a $-15^{\circ} \mathrm{C}$. Assim, estes analitos foram determinados, imediatamente após o descongelamento de cada amostra. A parte restante foi mantida sob o refrigeração a $4^{\circ} \mathrm{C}$ durante períodos de até 2 meses até todos os eletroferogramas (cátions e ânions) terem sido determinados e a condutividade e o $\mathrm{pH}$, medidos.

As 25 amostras analisadas representaram cerca de $484 \mathrm{~mm}(31 \%)$ de um total pluviométrico de $1563 \mathrm{~mm}$ durante o período de coleta, ou seja, utilizou-se uma amostra bastante representativa para estimar o fluxo dos íns majoritários em água de chuva.

Os frascos de polietileno usados para as amostras e medições do "branco" foram lavados previamente com uma solução detergente não iônico e lavados abundante e repetidamente com água deionizada (Fornaro et al., 1993), sendo guardados preenchidos com água. 


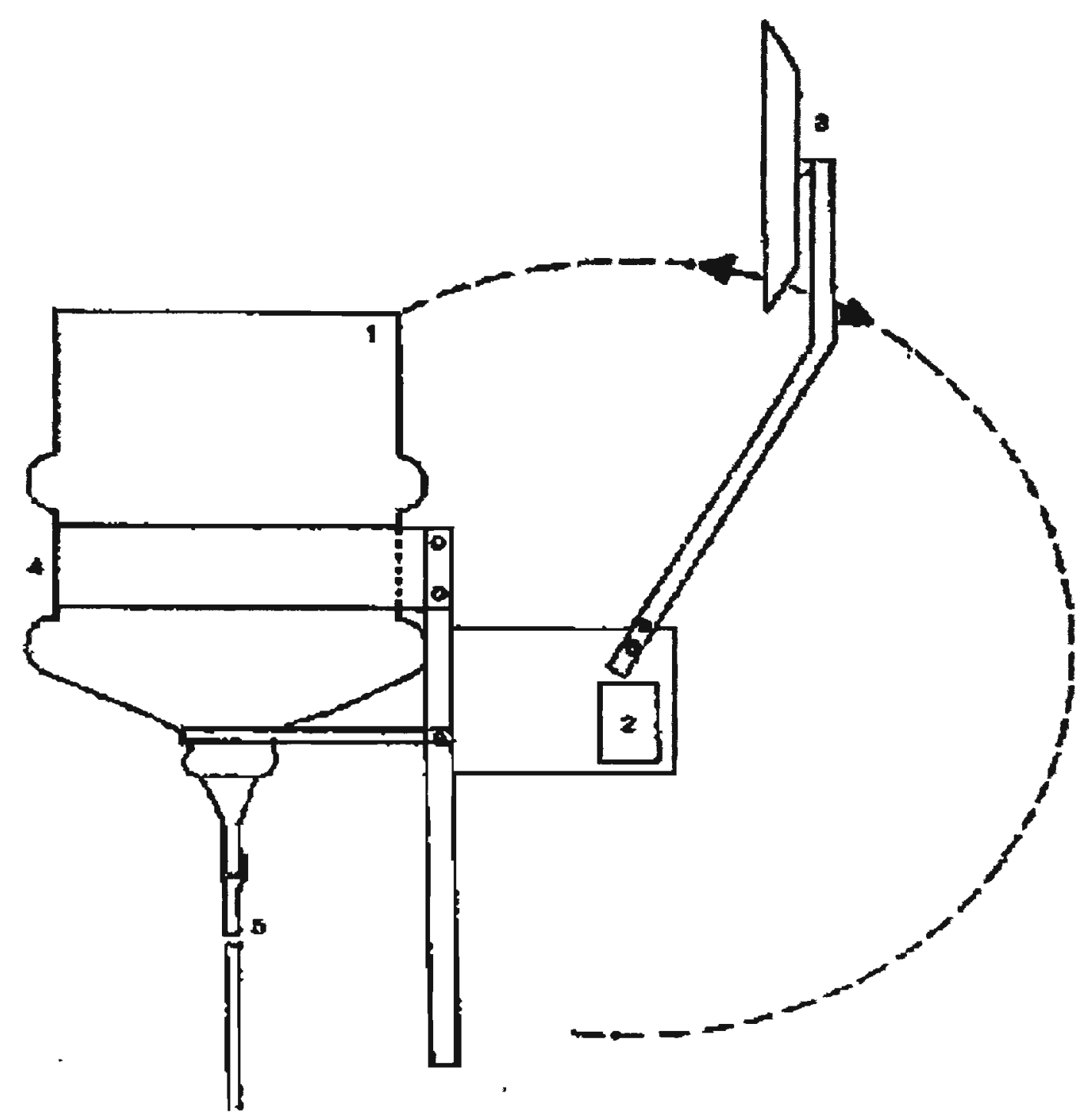

Figura 6.3.1 Coletor automático para deposição úmida: 1- Funil de policarboneto; 2- Motor; 3- Tampa articulada; 4- Cinto de fixação; 5- Tubo de escoamento das amostras. 


\subsection{DETERMINAÇÃO DE ÍONS EM ÁGUA DE CHUVA POR ELETROFORESE CAPILAR COM DETECÇÃO CONDUTOMÉTRICA SEM CONTATO}

Neste trabalho, as determinações por CE-CCD foram dirigidas aos principais cátions $\left(\mathrm{Na}^{+}, \mathrm{Ca}^{2+}, \mathrm{K}^{+}\right.$e $\left.\mathrm{NH}_{4}{ }^{+}\right)$e aos ânions inorgânicos $\left(\mathrm{SO}_{4}{ }^{2-}\right.$, $\left.\mathrm{NO}_{3}{ }^{-} \mathrm{e} \mathrm{Cl}{ }^{-}\right)$.

$\mathrm{O}$ equipamento de $\mathrm{CE}$ foi construído no laboratório, os detalhes da construção e do instrumento podem ser encontrados na literatura (Fracassi et al., 1998). Um desenho esquemático simplificado encontra-se na Figura 4.1.4.1, no Capítulo IV).

Os eletroferogramas foram obtidos utilizando-se capilar de sílica fundida com $70 \mathrm{~cm}$ de comprimento e diâmetro interno de $75 \mu \mathrm{m}$. Durante a introdução da amostra, a extremidade esquerda do capilar é introduzida temporariamente no vial da amostra e a injeção é promovida por ação da gravidade, mediante desnivelamento de $10 \mathrm{~cm}$ por $40 \mathrm{~s}$. Todas as separações foram feitas sob uma diferença de potencial de $20 \mathrm{kV}$ nas extremidades do capilar. Para cátions, o potencial mais negativo foi aplicado na extremidade (direita) perto do detector; para ânions, a polaridade foi invertida.

Os dois anéis paralelos do detector tem uma separação de $1 \mathrm{~mm}$ e envolvem o capilar $60 \mathrm{~cm}$ após o ponto da injeção; um anel foi excitado com onda senoidal de $2,0 \mathrm{~V}$ pico a pico e freqüência de $1,1 \mathrm{MHz}$. $\mathrm{O}$ outro anel foi conectado ao circuito amplificador/retificador, terminando em um conversor analógico/digital de um cartão de PCL 711 (Advantech), conectado a um micro computador. Os eletroferogramas são exibidos no monitor do micro computador em tempo real e armazenados para a integração dos picos. A integração melhora a precisão em comparação com a alturas dos picos, e foi feita com o software do Origin 5.0 (Microcal). 
Os tampões de corrida foram preparados diariamente e consistiram em uma solução que contem ácido 2-(N-morfolino)-etanosulfônico (MES) 20 mmol $\mathrm{L}^{-1}$ e histidina (His) $20 \mathrm{mmol} \mathrm{L}^{-1}$. Nas análises de cátions, adicionou-se éter 18-crown-6 2,5 mmol $\mathrm{L}^{-1}$ ao tampão de corrida com a finalidade de complexar o $\mathrm{K}^{+}$, modificando sua mobilidade efetiva, para que não houvesse sobreposição com o pico do $\mathrm{NH}_{4}^{+}$. Para a análise dos ânions, adicionou-se brometo de cetiltrimetilamônio (CTAB) $0,2 \mathrm{mmol} \mathrm{L}^{-1}$ ao tampão de corrida para promover a inversão do sentido do fluxo eletrosmótico.

O capilar foi condicionado antes de cada sessão de análises com fluxo constante de solução de $\mathrm{NaOH} 0,1 \mathrm{~mol} \mathrm{~L}^{-1}$ por 15 minutos e, para o mesmo período, com solução de tampão; posteriormente, aplicou-se alta tensão até a estabilização da linha base e do sinal de condutância.

A equivalência de análises de água de chuva por $\mathrm{CI}$ e $\mathrm{CE}$, ambas com detecção condutométrica, foi demonstrada para ânions por Valsecchi et al. (1997). Para tanto, utilizou água de chuva padrão SRM 2694-I e 2694-II do NIST. O fornecimento destes materiais de referência padrão foi interrompido pelo NIST, mas misturas de concentrações conhecidas dos íons de interesse foram preparadas no laboratório para avaliar os tempos da eletromigração, estabelecer as curvas de calibração baseadas nas áreas dos picos e avaliar os limites de detecção.

Para identificar os picos dos ions de interesse e para testes de recuperação efetuaram-se adições de padrão às amostras reais de água de chuva.

Durante o período trabalhado, o procedimento da adição de padrão gerou resultados de exatidão similar ao do uso direto da curva de calibração para alguns dos íons estudados (observou-se o mesmo coeficiente angular para as retas ajustadas por regressão). Isto favoreceu o uso direto das curvas de calibração preparadas no começo de cada sessão (verificada às vezes no 
fim de um período trabalhado) em vez do método da adição de padrão, mais trabalhoso.

Como padrão interno para cátions, adicionou-se íons de lítio às amostras durante o estágio do desenvolvimento do método CE-CCD.

A condutividade e o $\mathrm{pH}$ das amostras foram medidos com equipamentos da Digimed (Brasil), modelo DM31 e DM20, respectivamente, após calibração apropriada.

Nenhuma medida direta do bicarbonato foi feita, porém, a concentração deste ânion foi estimada aproximadamente a partir das medidas de $\mathrm{pH}$, usando as constantes de dissociação do ácido carbônico e da constante de Henry de $\mathrm{CO}_{2}$, considerando o equilíbrio existente entre a fase líquida e a fase gasosa $\left(\mathrm{P}_{\mathrm{CO} 2}=0,00035 \mathrm{~atm}\right)$.

Todos os reagentes utilizados foram de grau analítico. Ácido 2-[Nmorfolino] etanosulfônico (MES), L-histidina (His), 18-crown-6 e N-cetilN,N,N-trimetilamônio brometo (CTAB) foram comprados da Merck (Alemanha). O tampão de corrida e as misturas padrão foram preparados diluindo-se soluções estoque de $100 \mathrm{mmol} \mathrm{L}^{-1}$, preparadas com água ultra pura (NANOPure, Barnstead, EUA) e filtradas com um filtro de $0,2 \mu \mathrm{m}$ em uma seringa.

\subsection{RESULTADOS E DISCUSSÃO}

Sendo a condutividade o método de detecção universal para a cromatografia de íons, considerou-se que também para CE esta forma de deteç̧ão poderia ser vantajosa. Esta união da CE (técnica de separação de alta resolução) com a condutometria (sensível detector universal para íons) 
resultou em um modo de detecção por condutividade sem contato, particularmente eficaz (oscilométrico, sem nenhum contato direto dos eletrodos com a solução) (Fracassi et al., 1998). Como demonstrado aqui, a CE-CCD é muito apropriada por simplificar e reduzir custos na determinação dos principais compostos poluentes iônicos em água de chuva.

Eletroferogramas típicos de amostras reais de água de chuva podem ser vistos na Figura 6.5.1 para os cátions (Figura A) e os ânions (Figura B). O mesmo tampão de MES/His (que difere somente no modificador do fluxo eletrosmótico) produziu excelente definição dos picos, tanto para os cátions como para os ânions, em curto espaço de tempo (3-4 min). Não mais do que 30 minutos são necessários para modificar o sistema da separação do cátion à do ânion (inversão da polaridade da alta tensão, troca do eletrólito e estabilização da linha base), uma definitiva vantagem perante a $\mathrm{CI}$, especialmente para os laboratórios que não têm equipamentos em duplicata, um para cátions e outro para ânions.

O método da adição de um padrão interno foi avaliado para a determinação $\mathrm{CE}-\mathrm{CCD}$ dos cátions, o lítio foi selecionado porque não aparece nas amostras de água de chuva. Entretanto, devido à boa estabilidade do equipamento e da repetibilidade dos eletroferogramas, torna-se desnecessário o uso do padrão interno em análises rotineiras, embora seja uma prática recomendável (Haber et al., 1998). Além dos ânions inorgânicos determinados, pequenos picos de ânions de ácidos carboxílicos (formiato e acetato) foram detectados em vários eletroferogramas, mas não foram quantificados neste ciclo inicial de amostragens. Isto porque a literatura sobre amostras de água de chuva, afirmar que, se não forem mantidas congeladas adequadamente, podem apresentar perdas consideráveis nas concentrações de formiato e acetato, com aumento eventual no $\mathrm{pH}$, devido ao ataque bacteriológico (Herlihy et al., 1987; Guiang et al., 1984; Lacaux et al., 1992; 
Schwarzenbach et al., 1993). Como mencionado anteriormente, devido à prioridade dada à determinação amperométrica de espécies mais instáveis (como o $\mathrm{H}_{2} \mathrm{O}_{2}$ e o $\mathrm{HSO}_{3}^{-}$, relatados em Rocha, F.R., 1999), os eletroferogramas foram determinados mais tarde (às vezes após dias ou semanas do armazenamento a $4^{\circ} \mathrm{C}$ ); desta forma, as informações sobre formiato e acetato, nesta etapa, não mereciam confiança.

A Tabela 6.5.1 reproduz os limites de deteç̧ão (LD) para a espécie de interesse, correspondentes a concentração de analito que proporciona sinal 3 vezes superior ao nível de ruído médio da linha base. Estes limites de detecção são suficientemente baixos para a determinação de pelo menos sete íons inorgânicos majoritários $\left(\mathrm{Cl}^{-}, \mathrm{NO}_{3}{ }^{-}, \mathrm{SO}_{4}{ }^{2-}, \mathrm{Na}^{+}, \mathrm{K}^{+}, \mathrm{NH}_{4}^{+} \mathrm{e} \mathrm{Ca}{ }^{2+}\right)$, salvo, talvez, para amostras de água de chuva de algumas das regiões mais remotas e muito limpas. O magnésio apresenta um pico bem separado (Figura 6.5.1 A, pico 5) mas um limite de detecção um tanto mais elevado (Tabela 6.5.1) e sua menor abundância nas amostras podem impedir uma determinação precisa. Somente para algumas amostras, as concentrações do magnésio superaram o limite de determinação (3,3 x LD). Assim, os escassos resultados não foram incluídos na tabela. 

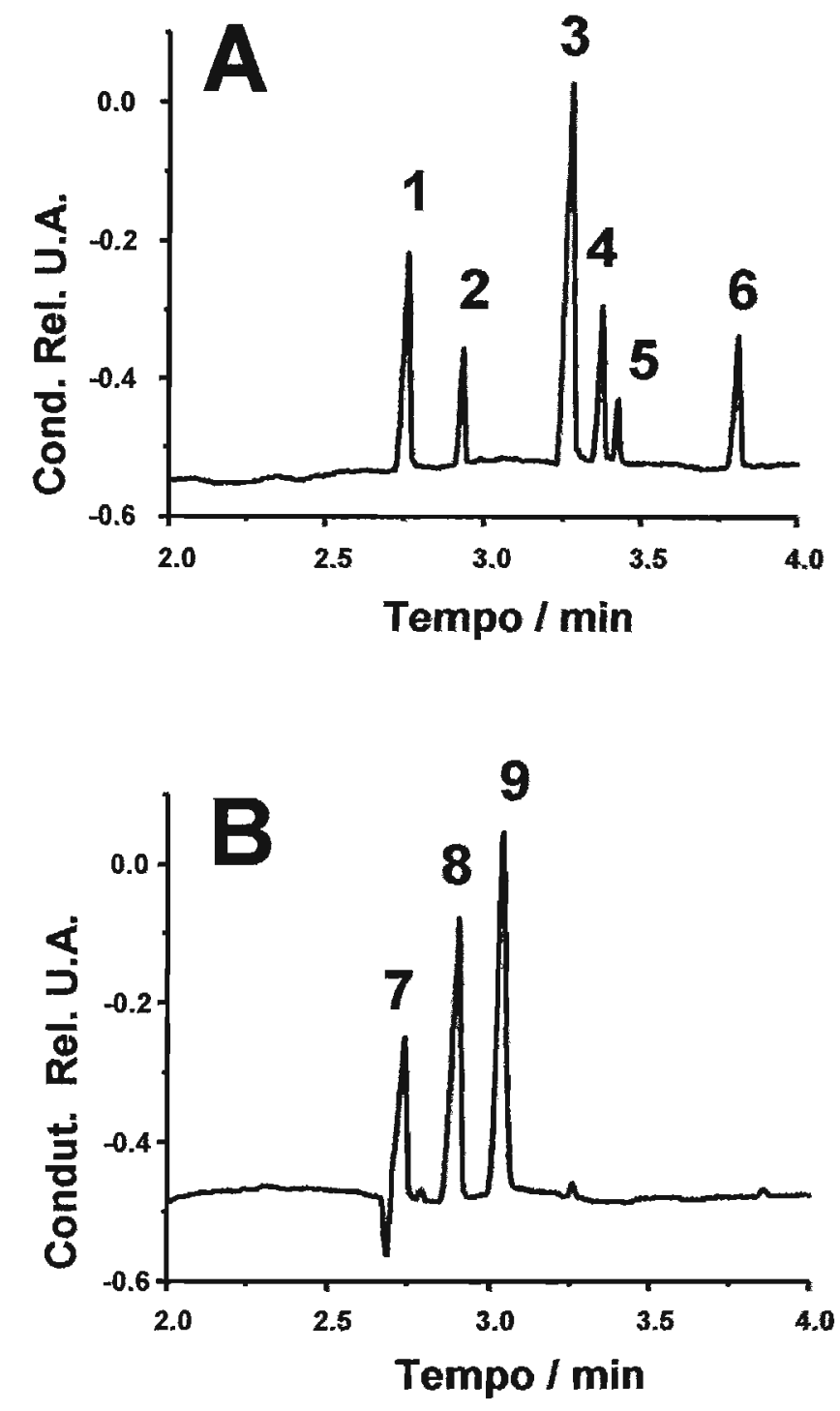

Figura 6.5.1 Eletroferogramas de amostras de água de chuva: (A) análise de cátions tampão de corrida MES/His $20 \mathrm{mmol} \mathrm{L}^{-1}$ (pH 6,2) e 18-crown-6 2,5 $\mathrm{mmol} \mathrm{L}^{-1}$ (B) análise de ânions - tampão de corrida MES/His $20 \mathrm{mmol} \mathrm{L}^{-1}$ (pH 6,2) e CTAB 0,2 mmol L $\mathrm{p}^{-1}$. Circunstâncias comuns: capilar de sílica fundida $75 \mu \mathrm{m}$ de diâmetro e $70 \mathrm{~cm}$ do comprimento; tensão da separação $20 \mathrm{kV}$; injeção por gravidade $(10 \mathrm{~cm}, 40 \mathrm{~s})$; deteção por condutividade sem contato em $1,1 \mathrm{MHz}$. Picos identificados (concentrações em $\mu \mathrm{mol} / \mathrm{L}$ nos parênteses): $1-\mathrm{NH}_{4}{ }^{+}(20,2) ; 2-\mathrm{K}^{+}(4,6) ; 3-\mathrm{Ca}^{2+}(31,1) ; 4-\mathrm{Na}^{+}(8,1) ; 5-$ $\mathrm{Mg}^{2+}$ (não determinado); 6- $\mathrm{Li}^{+}\left(20,0\right.$ padrão interno); $7-\mathrm{Cl}^{-}(50,6) ; 8-\mathrm{NO}_{3}{ }^{-}(43,6) ; \mathrm{e} 9-$ $\mathrm{SO}_{4}{ }^{2-}(33,8)$. 
Tabela 6.5.1 Limites de detecção (relação sinal-ruído 3) obtidos pela eletroforese capilar de zona com detecção condutométrica sem contato, CE$\mathrm{CCD}$, de cátions e de ânions

\begin{tabular}{|c|c|c|}
\hline & \multicolumn{2}{|c|}{ Limites de Detecção } \\
\hline Íon & $\mu \mathrm{mol} \mathrm{L} \mathbf{L}^{-1}$ & $\mu g L^{-1}(p p b)$ \\
\hline $\mathrm{NH}_{4}^{+}$ & 0.58 & 10 \\
\hline $\mathrm{K}^{+}$ & 0.43 & 17 \\
\hline $\mathrm{Ca}^{2+}$ & 0.38 & 15 \\
\hline $\mathrm{Na}^{+}$ & 0.41 & 9.4 \\
\hline $\mathrm{Mg}^{2+}$ & 1.1 & 24 \\
\hline $\mathrm{Cl}^{-}$ & 1.4 & 48 \\
\hline $\mathrm{NO}_{3}^{-}$ & 1.6 & 96 \\
\hline $\mathrm{SO}_{4}{ }^{2-}$ & 1.2 & 115 \\
\hline
\end{tabular}

Os limites de detecção correspondem a 3,3 vezes os valores de $L D$.

Resumidamente, os LDs obtidos com CE-CCD (Tabela 6.5.1) não podem ainda competir com a $\mathrm{Cl}$, mas atendem às necessidades da aplicação pretendida aqui e se mostram favoráveis (similar para ânions e 3 vezes melhor para cátions) quando comparados com os valores da literatura para $\mathrm{CE}$ com a popular deteç̧ão UV indireta (Krivácsy et al., 1997).

O balanço iônico para cada uma das amostras analisadas estava dentro de $12 \pm 10 \%$ na média, diferindo em $25 \%$ somente para uma amostra. As médias aritméticas de todos os valores foram $\sum_{\text {cátions }}=115 \pm 67 \mu \mathrm{eq} \mathrm{L}^{-1} \mathrm{e}$ $\sum_{\text {ânions }}=105 \pm 53 \mu \mathrm{eq} \mathrm{L}^{-1}$. A concentração de bicarbonato, calculada como 
mencionado anteriormente, só foi relevante $(>10 \%$ da concentração total dos ânions) para as quatro amostras mais "limpas" e menos ácidas de água de chuva. Adicionou-se à determinação dos íons em água de chuva por CE-CCD a concentração do íon $\mathrm{H}^{+}$(obtida através das medidas de $\mathrm{pH}$ ), utilizado para obter a condutância calculada para cada amostra. Excluindo as quatro amostras mais diluídas, as diferenças relativas de valores calculados e medidos variaram de $2 \%$ a $20 \%(\mathrm{~N}=21)$. A média das condutâncias calculadas foi de $17 \pm 9 \mu \mathrm{S} \mathrm{cm}^{-1}$, favoravelmente comparáveis com as medidas, de $15 \pm 11 \mu \mathrm{S} \mathrm{cm}^{-1}$. Estas verificações de consistência internas indicam a qualidade dos dados na determinação dos íons majoritários por $\mathrm{CE}-\mathrm{CCD}$, e mostram que outras espécies iônicas, desprezadas aqui, como o magnésio e os ânions dos ácidos orgânicos (possivelmente decompostos) teve uma importância secundária nas amostras disponíveis.

Durante o período estudado, a variabilidade das concentrações de todos os íons foi muito elevada e apresentou uma distribuição não normal, como mostrado na Figura 6.5.2.

Os íns predominantes foram amônio e cloreto, seguido pelo cálcio, pelo nitrato e pelo sulfato. Os resultados obtidos para $\mathrm{NH}_{4}{ }^{+}, \mathrm{K}^{+}, \mathrm{Na}^{+}, \mathrm{NO}_{3}{ }^{-} \mathrm{e}$ $\mathrm{SO}_{4}{ }^{2-}$, ficaram notavelmente próximos daqueles publicados por Paiva et al. (1997) para amostras somente de precipitação úmida coletadas em São Paulo durante o período de setembro 1993 a maio 1994 (análises dos íons foram feitas por CI). As concentrações médias ponderadas pelo volume (VWM) de amostra coletado, para o cloreto e o cálcio, aparentemente aumentaram, enquanto que a concentração de $\mathrm{H}^{+}$diminuiu. $\mathrm{O}$ aumento da presença do cálcio, possivelmente como carbonato, pode ser um fator relevante para a diminuição da acidez livre. 


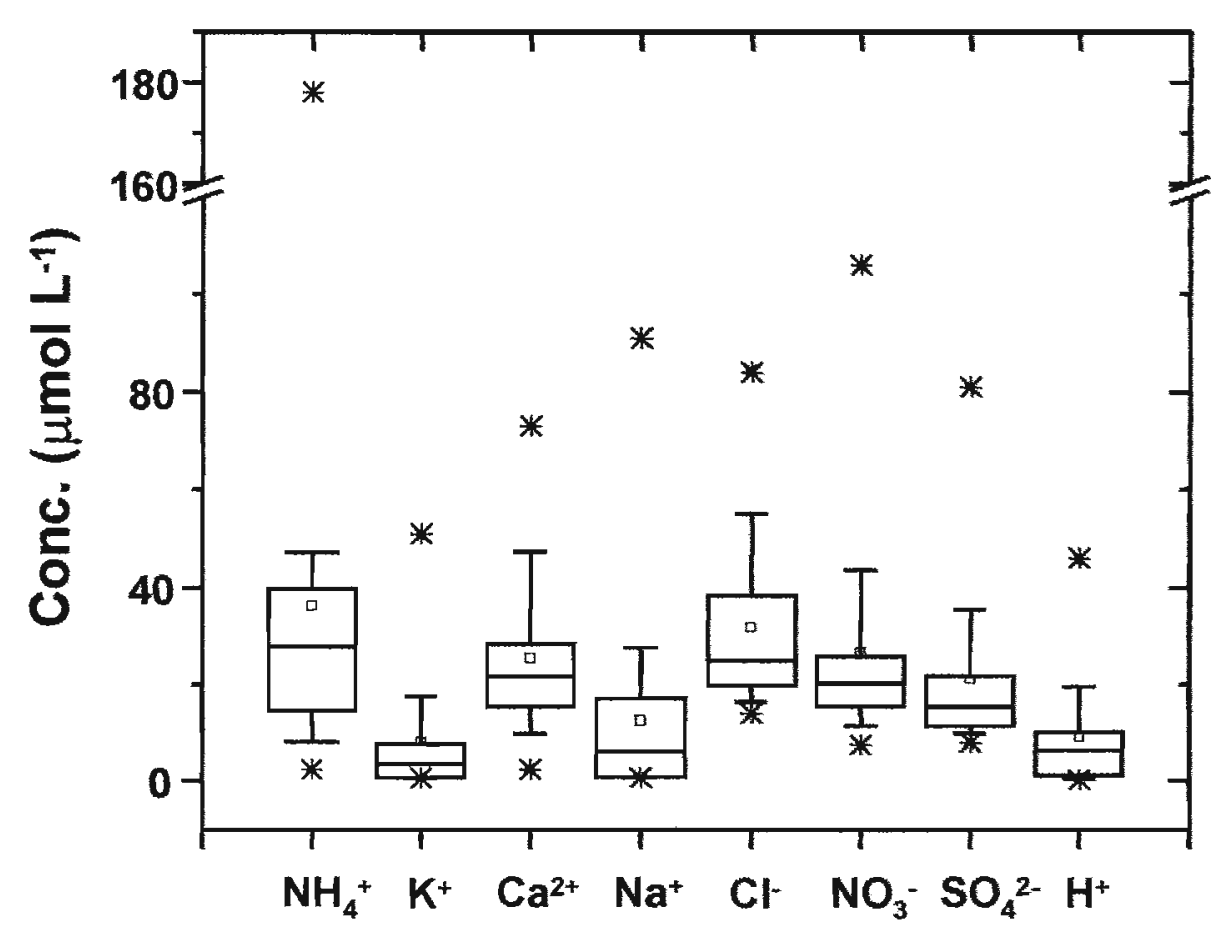

Figura 6.5.2 Variações das concentrações de espécies químicas presentes na água de chuva, durante o período de maio 1997 a março 1998 na cidade de São Paulo. Representação box and whisker: linhas horizontais das caixas: $25 \%, 50 \%$ (linha do meio) e $75 \%$ dos resultados; barras de erros: $5 \%$ e $95 \%$ dos valores; $\left({ }^{*}\right)=$ valores mínimos e máximos; $(\square$ na caixa $)=$ média aritmética.

As concentrações médias mensais dos íons estudados são mostradas na Figura 6.5.3 (A) para os cátions e ânions, respectivamente. Os picos referentes às concentrações de nitrato, sulfato e amônio foram determinados em agosto/1997, com $\sum_{\text {cátions }}=271 \mu \mathrm{eq} \mathrm{L} \mathrm{L}^{-1} \mathrm{e} \sum_{\text {âniows }}=289 \mu \mathrm{eq} \mathrm{L} \mathrm{L}^{-1}, \operatorname{logo}$ após 
um mês inteiro sem deposição úmida coletável, como mostrado pela curva mensal de precipitação (Figura 6.5.3 (C)). Em São Paulo, diferentemente de regiões de latitude mais elevadas, este aumento nas concentrações não pode ser atribuído ao aumento nas emissões por queima de combustíveis fósseis visando o aquecimento das edificações durante a estação de inverno (junho a setembro). Isto porque a temperatura é amena e, além do mais, a fonte predominante de energia é a eletricidade gerada por hidroelétricas, ao invés do óleo ou gás.

Entretanto, os ventos e as chuvas escassas e os fenômenos de inversão térmica são freqüentes em tempo de inverno em São Paulo, favorecendo o acúmulo de poluentes na atmosfera. A chegada de massas de ar mais frio que vêm da região antártica conduz à formação de nuvens e eventuais precipitações. A combinação do efeito de "limpeza" pelas nuvens e abaixo delas (durante o evento de chuva) dos aerossóis acumulados e dos poluentes solúveis confere determinada poluição a água da chuva, como demonstram os picos de concentrações altas dos poluentes na Figura 6.5.3 (A) e (B). Durante o verão, o continente estava sob a influência de um intenso El Niño (1997/98); a precipitação (Figura 6.5.3 (C)) foi ligeiramente acima da média, devido aos processos convectivos e as massas de ar úmidas que chegavam a São Paulo. Porém, nenhuma mudança importante foi observada nas

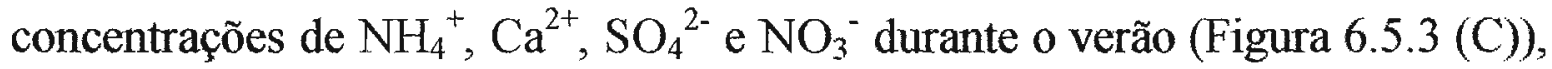
mas em termos do fluxo dos íons, a precipitação elevada aumentou a importância relativa dos processos de remoção pela água de chuva em comparação com a estação seca. 


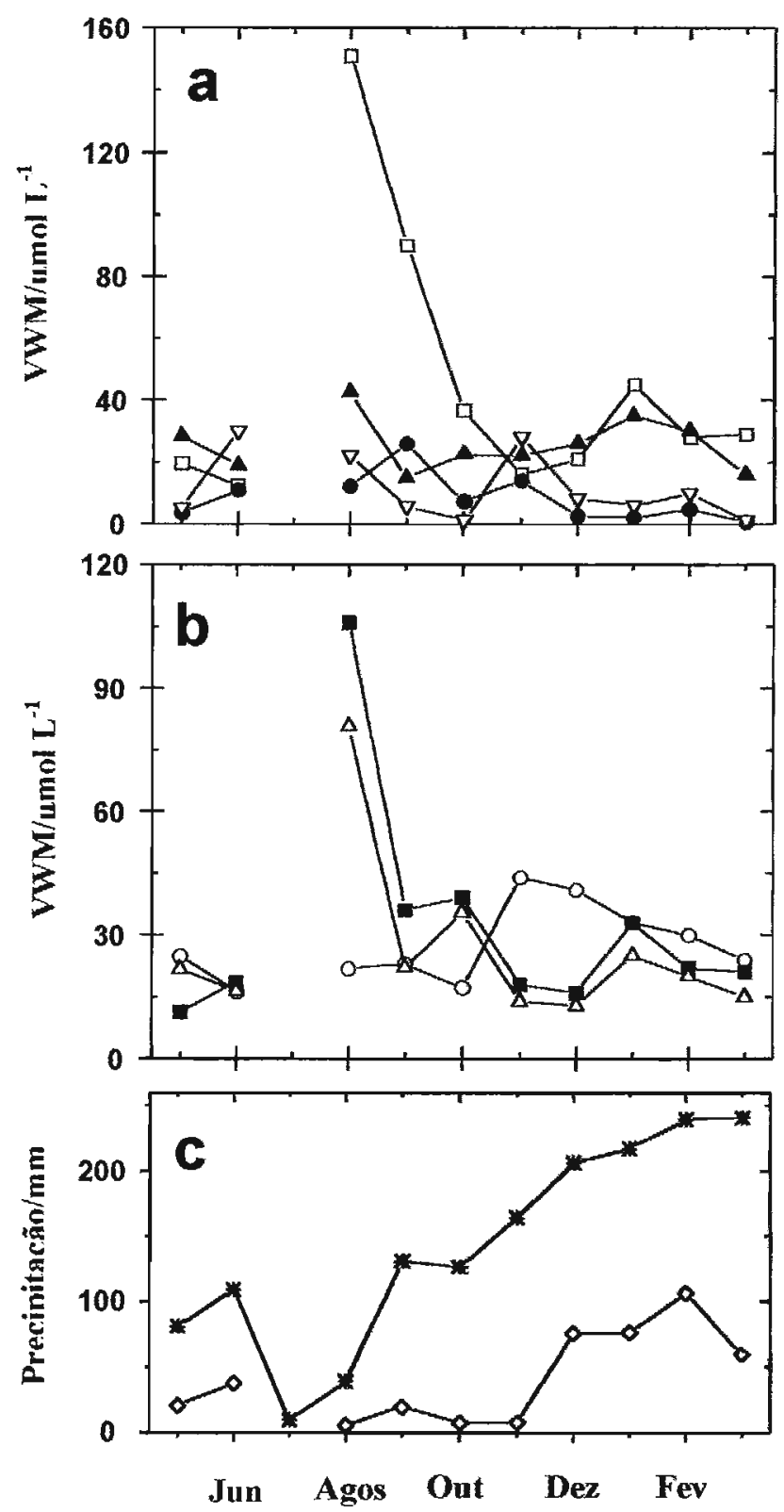

Figura 6.5.3 Precipitação mensal e concentração iônica (VWM) da deposição úmida, amostradas em São Paulo durante o período de Maio 1997 a Março de

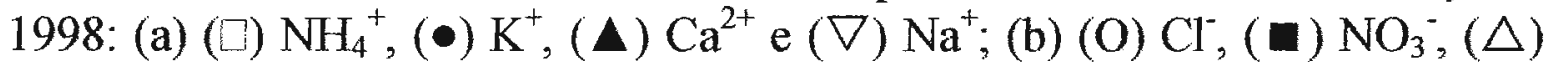
$\mathrm{SO}_{4}{ }^{2-} \mathrm{e}(\mathrm{c})\left(^{*}\right)$ precipitação total, $(\diamond)$ precipitação coletada - não houve coleta de chuva no mês de julho.

Em novembro, os íons do sódio e de cloreto mostraram certo aumento na concentração (Figura 6.5.3 (A) e (B)). Atribui-se a esse fato, a 
predominância de ventos provenientes do litoral (S-SE ou L). Por situar-se a cidade de São Paulo a pequena distância litoral (o sitio de amostragem dista aproximadamente $45 \mathrm{~km}$ da costa) e recebe freqüentemente os ventos de sudeste que vem do oceano.

Em regiões, que podem ser influenciadas pela brisa marítima, é comum distinguir as frações marinhas ("sea salt") e as adicionais ("non-sea salt") (fontes continentais e/ou antrópicas) dos íons majoritários em água de chuva (Keene et al., 1986). As equações e as razões entre os íons presentes na água do mar, encontrados na literatura (Keene et al., 1986), foram usadas para estimar as contribuições do sal marinho (sea-salt) na água de chuva coletada, com base na suposição de que todo o sódio encontrado na chuva seja de origem marinha.

Cabe ressaltar que esta aproximação extensamente usada é susceptível de erro porque negligencia as contribuições possíveis de sódio que vem da poeira da crosta terrestre e das emissões antrópicas. O magnésio foi proposto como uma espécie "traçadora" alternativa, porque é menos sujeito a tais interferências (Keene et al., 1986). Porém, raramente tem sido usado, talvez porque sua concentração é 4,4 vezes inferior à do sódio no sal marinho, aumentando as incertezas analíticas relativas, como era o caso neste estudo, onde a concentração de $\mathrm{Mg}^{2+}$ (não relatado) estava próxima ao limite de detecção em muitas amostras.

Devido às baixas concentrações do íon de hidrogênio e das espécies reduzidas e oxidadas de nitrogênio na água do mar, as contribuições marinhas para as espécies medidas de $\mathrm{H}^{+}, \mathrm{NH}_{4}^{+}{\mathrm{e} \mathrm{NO}_{3}}^{-}$foram desprezadas.

Como pode ser visto na Tabela 6.5.2, a qual inclui as concentrações das VWM dos íons, há um predominância das contribuições do "non-sea salt" (> 95\%) para quase todos os íons; entretanto, o cloreto foi fornecido igualmente por ambas as fontes. Um retrato similar foi observado durante o periodo de 
outubro de 1983 a 1985, onde Forti et al. (1990) atribuíram o enriquecimento de $\mathrm{Ca}^{2+}, \mathrm{K}^{+}$e de $\mathrm{Mg}^{2+}$ à ressuspensão de poeira do solo e da superficie urbana.

Diferentemente de São Paulo, o Rio de Janeiro, a segunda maior região metropolitana do Brasil, espalha-se ao longo da costa. Conseqüentemente, para o período de setembro 1988 a agosto 1989 (Mello, 2001), a concentração média ponderada pelo volume (VWM) encontrada para o sódio era 5 vezes mais elevada do que no estudo atual e todo o cloreto e $70 \%$ do magnésio foram atribuídos à origem marinha. Todos os íns restantes foram atribuidos predominantemente (> 80\%) de origem continental/antrópica (non-sea salt).

Para avaliar a importância relativa da influência continental na metrópole de São Paulo, um estudo da deposição úmida em quatro locais no interior do continente (Lara et al., 2001) durante o período de agosto 1997 a julho 1998 foi relatado na literatura, sendo muito similar em alguns aspectos a este trabalho. Os dados de Santa Maria foram escolhidos para a comparação, por ser o mais distante dos locais, localizado $180 \mathrm{~km}$ a noroeste de São Paulo, e pertencente a uma região essencialmente agrícola (embora não seja suficientemente distante para excluir as influências provenientes do transporte a longa distância de poluentes originados em São Paulo). $\mathrm{O}$ ín $\mathrm{H}^{+}$foi a única espécie com uma concentração VWM maior do que em São Paulo; $\mathrm{Ca}^{2+}$ apresentou apenas $16 \%$ do valor dado na Tabela 6.5 .2 (coluna 2) e os íons restantes variaram relativamente de $30 \%$ a $60 \%\left(\mathrm{Cl}^{-} \approx \mathrm{Na}^{+} \approx \mathrm{SO}_{4}{ }^{2-}<\mathrm{NH}_{4}^{+}<\right.$ $\mathrm{NO}_{3}{ }^{-} \approx \mathrm{K}^{+}$). Isto indica que a chuva estudada aqui demonstra ser influenciada de forma mais significativa pelo material emitido/convertido pelas próprias atividades (naturais e antrópicas) da metrópole de São Paulo. Por outro lado, em concordância com estudos atuais relatados na introdução desta tese, sugere a influência do transporte à longa distância dos poluentes emitidos pela grande São Paulo para o interior do estado. 
Além das concentrações VWM, os fluxos anuais para as espécies medidas foram incluídos na Tabela 6.5.2, assim como os fluxos avaliados anteriormente por Forti et al. (1990) e por Fornaro (1991). Esta comparação não denota significativas alterações, após 13 anos, na deposição úmida dos cátions $\mathrm{K}^{+}, \mathrm{Ca}^{2+}$ e $\mathrm{Na}^{+}$, nem para o ânion $\mathrm{NO}_{3}^{-}$. Para o sulfato, a deposição avaliada durante o período de 1989/1990 foi maior $\left(3,8 \mathrm{~g} \mathrm{~m}^{-2} \mathrm{ano}^{-1}\right)$, embora o valor de 1983/1985 possa ter sido subestimado, como relatado pelos autores do estudo (Forti et al., 1990) devido às incertezas em suas medidas turbidimétricas.

Um programa de redução na emissão de $\mathrm{SO}_{2}$ para a metrópole de São Paulo (redução do enxôfre no óleo e na gasolina) resultou em uma diminuição quase linear da concentração média do $\mathrm{SO}_{2}$ na fase gasosa da atmosfera, de $140 \mu \mathrm{g} \mathrm{m}^{-3}$ em 1979 para $50 \mu \mathrm{g} \mathrm{m}^{-3}$ em 1985 (CETESB, 2000). Desde então, a redução de $\mathrm{SO}_{2}$ tornou-se mais lenta mas teve continuidade, possivelmente por causa de redução adicional do índice de enxôfre nos combustiveis e de introdução compulsória de catalisadores na exaustão e/ou da injeção direta do combustível, fatores estes que acabaram por compensar o acentuado crescimento do número de veículos de combustão interna. Neste cenário, poder-se-ia esperar uma tendência de diminuição do fluxo anual de sulfato; porém, devido a escassez e as incertezas dos valores na Tabela 6.5.2, estudos adicionais são necessários. 
Tabela 6.5.2 Concentrações médias ponderadas pelo volume, frações do "nonsea-salt" e comparações do fluxo de espécies iônicas presentes em água de chuva em diferentes períodos na região de São Paulo

\begin{tabular}{|c|c|c|c|c|c|}
\hline & \multicolumn{3}{|c|}{$05 / 1997-03 / 1998^{a}$} & $\begin{array}{l}07 / 1989 \\
11 / 1990^{b}\end{array}$ & $\begin{array}{l}10 / 1983 \\
10 / 1985^{c}\end{array}$ \\
\hline Íon & $\underset{\left(\mu \mathrm{mol} \mathrm{L} \mathbf{L}^{-1}\right)}{\mathbf{V W M}}$ & $\begin{array}{l}\text { Non-sea- } \\
\text { salt }(\%)\end{array}$ & Flux & $\begin{array}{l}\text { co na Depo } \\
\left(\mathrm{g} \mathrm{m}^{-2} \text { ano }\right.\end{array}$ & Úmida \\
\hline $\mathrm{NO}_{3}^{-}$ & 22 & 100 & 2,2 & 2,1 & 2,6 \\
\hline $\mathrm{SO}_{4}{ }^{2-}$ & 17 & 97 & 2,5 & 3,8 & $(2,4)^{*}$ \\
\hline $\mathrm{Cl}^{-}$ & 29 & 41 & 1,6 & 0,53 & 0,85 \\
\hline $\mathrm{K}^{+}$ & 5,8 & 97 & 0,35 & - & 0,29 \\
\hline $\mathrm{Ca}^{2+}$ & 23 & 99 & 1,4 & - & 1,15 \\
\hline $\mathrm{Na}^{+}$ & 12 & 0 & 0,43 & - & 0,33 \\
\hline $\mathrm{NH}_{4}^{+}$ & 28 & 100 & 0,78 & - & - \\
\hline
\end{tabular}

Cabe ressaltar, que nenhuma amostra apresentou sinal eletroforético para $\mathrm{HSO}_{3}^{-}$. Em estudos recentes de medidas amperométricas em (Rocha, 1999), não foi detectada a presença de $\mathrm{HSO}_{3}{ }^{-}$(LD de $2 \times 10^{-7} \mathrm{~mol} \mathrm{~L}^{-1}$ ), mas sim, a presença persistente de $\mathrm{H}_{2} \mathrm{O}_{2}$, capaz de oxidar sulfito a sulfato em todas as amostras. Desta forma, presume-se que a razão da ausência de $\mathrm{HSO}_{3}{ }^{-}$nas amostras de água de chuva, não tenha sido a sua oxidação durante os longos períodos de armazenamento das amostras. 
O fluxo de cloreto na deposição úmida, não explicado pela contribuição do sea-salt, foi maior em comparação com os períodos precedentes disponiveis na Tabela 6.5.2. Pode resultar do aumento da emissão de gases provenientes da incineração de rejeitos. Certamente, a combustão e a decomposição de compostos organoclorados, tais como polímeros de cloreto de polivinila, emitem $\mathrm{HCl}$ na fase gasosa (Sanusi et al., 1996).

O fluxo para amônio não foi avaliado em estudos precedentes na metrópole de São Paulo, mas Paiva et al. (1997) apresentaram uma concentração de VWM, de $26 \mu \mathrm{mol} \mathrm{L}^{-1}$, similar ao valor da Tabela 6.5.2. Em regiões do interior, como a de Santa Maria (acima mencionada), metade dessa concentração foi encontrada (Lara et al., 2001) e pode ser atribuída principalmente às práticas agrícolas, como o uso intensivo de fertilizantes. As fontes em São Paulo incluem certamente as emissões da própria população humana e do esgoto, vez que só uma fração é apropriadamente coletada e trarada.

Envolvendo a interação de fatores que influenciam a composição da água de chuva, os coeficientes de correlação entre os componentes principais foram avaliados para a série de dados de disponível. O método "bootstrap" (Efron e Tibshirani, 1991) foi utilizado para calcular os coeficientes de correlação. Embora mais complexo, este método fornece estimativas numéricas dos limites de confiança sem nenhuma necessidade de suposições sobre a distribuição da probabilidade específica do conjunto de dados.

$\mathrm{Na}$ Tabela 6.5.3, os valores dos limites do intervalo de confiança de 95\% são dados para os pares dos íons que apresentam um coeficiente de correlação médio $>0,5$. Nenhum par com correlação inversa comparavelmente elevada foi apurado do conjunto de dados. $\mathrm{Na}$ tabela, o $\mathrm{Cl}^{-}$ $x \mathrm{Ca}^{2+} \mathrm{e} \mathrm{o} \mathrm{Cl}^{-} \mathrm{x} \mathrm{K}^{+}$apresentaram um longo intervalo, sugerindo a diversidade das fontes destas espécies (continental/antrópica e fontes marinhas). 
As diferentes combinações dos íons $\mathrm{NO}_{3}{ }^{-}, \mathrm{SO}_{4}{ }^{2-}$ e $\mathrm{NH}_{4}{ }^{+}$aparecem na Tabela 6.5.3, com elevadas correlações e estreitos limites. Com uma escala um tanto mais larga, os mesmos dois ânions correlacionam-se bem com o $\mathrm{Ca}^{2+}$. Na análise de componentes principais, $\mathrm{PCA}$, os mesmos ions altamente correlacionados $\left(\mathrm{NO}_{3}{ }^{-}, \mathrm{SO}_{4}{ }^{2-}, \mathrm{NH}_{4}{ }^{+}\right)$apresentam os fatores mais elevados da componente principal, que explica $42 \%$ da variança total (Tabela 6.5.4).

Tabela 6.5.3 Coeficientes de correlação entre alguns íons encontrados em água de chuva em São Paulo, Maio 1997 a Março 1998

\section{Coeficientes de correlação}

\begin{tabular}{|c|c|c|c|}
\hline Pares de íons & $2,5 \%$ & $50 \%$ & $97,5 \%$ \\
\hline $\mathrm{NO}_{3}{ }^{-}$vs. $\mathrm{SO}_{4}{ }^{2-}$ & 0,98 & 0,94 & 0,77 \\
\hline $\mathrm{NH}_{4}^{+}$vs. $\mathrm{NO}_{3}^{-}$ & 0,98 & 0,89 & 0,73 \\
\hline $\mathrm{NH}_{4}{ }^{+} v s . \mathrm{SO}_{4}{ }^{2-}$ & 0,96 & 0,73 & 0,47 \\
\hline $\mathrm{Ca}^{2+}$ vs. $\mathrm{SO}_{4}^{2-}$ & 0,89 & 0,61 & 0,47 \\
\hline $\mathrm{Ca}^{2+}$ vs. $\mathrm{NO}_{3}^{-}$ & 0,79 & 0,50 & 0,29 \\
\hline $\mathrm{K}^{+}$vs. $\mathrm{Cl}^{-}$ & 0,80 & 0,47 & $-0,17$ \\
\hline $\mathrm{Ca}^{2+} v s \cdot \mathrm{Cl}^{-}$ & 0,70 & 0,42 & 0,13 \\
\hline
\end{tabular}


Tabela 6.5.4 Resultados da PCA de água de chuva em São Paulo durante o período de Maio 1997 a Março 1998. Somente componentes principais com autovalores maiores do que 1 e fator com valores absolutos maior do que 0,3 foram incluídos.

\section{Variáveis Fator 1 Fator 2 Fator 3}

\begin{tabular}{|c|c|c|c|}
\hline $\mathrm{Cl}^{-}$ & & 0,50 & \\
\hline $\mathrm{NO}_{3}^{-}$ & 0,44 & & \\
\hline $\mathrm{SO}_{4}{ }^{2-}$ & 0,35 & 0,31 & \\
\hline $\mathrm{NH}_{4}^{+}$ & 0,43 & & \\
\hline $\mathrm{K}^{+}$ & & & 0,58 \\
\hline $\mathrm{Ca}^{2+}$ & & 0,58 & \\
\hline $\mathrm{Na}^{+}$ & & & \\
\hline autovalores & 5,03 & 2,58 & 1,65 \\
\hline \% Variança & 42,3 & 21,7 & 13,9 \\
\hline
\end{tabular}

O segundo fator apresenta-se significativamente maior para o cálcio, cloreto e sulfato. Como mencionado anteriormente, o cálcio apresenta concentrações mais elevadas na metrópole, quando comparada com uma região agrícola no interior. Assim, a ressuspensão da poeira da superfície urbana pode ser uma fonte relevante. Estas são indicações adicionais de que as emissões locais das espécies consideradas ou de seus precursores prevalecem na metrópole de São Paulo, em comparação com outras fontes continentais de poluentes. 
Naturalmente, este estudo sobre a deposição úmida na superficie não distingue entre as formas de remoção dos poluentes através de processos que ocorram nas nuvens ou durante o evento da chuva, nem esclarece os mecanismos que causam a incorporação do sulfato, do nitrato e do amônio na água de chuva.

A absorção da amônia combinada com a incorporação do carbonato de cálcio pode explicar a concentração mais baixa de $\mathrm{H}^{+}$em comparação com o interior. Dentre as possíveis rotas, figura a formação de aerossóis que contêm $\mathrm{NH}_{4} \mathrm{NO}_{3},\left(\mathrm{NH}_{4}\right)_{2} \mathrm{SO}_{4}, \mathrm{Ca}\left(\mathrm{NO}_{3}\right)_{2}$ e $\mathrm{CaSO}_{4}$.

A eletroforese capilar com detecção condutométrica sem contato mostrou-se muito apropriada para as análises dos componentes iônicos majoritários em amostras de água de chuva coletadas em São Paulo. O tampão de corrida (MES/His) provou ser versátil o suficiente para promover a separação dos cátions e de ânions em curto tempo de análise, o que simplificou a aplicação rotineira do método. Os limites de detecção foram satisfatórios para a análise de água de chuva em regiões com a atividade antrópica (rural ou urbana ).

$\mathrm{O}$ uso do detector de condutividade sem contato exclui problemas de contaminação ou com bolhas de ar nos eletrodos e evita a interferência do elevado campo elétrico usado na separação de CE.

Dentre as razões que justificam a utilização CE-CCD na análise de água de chuva (ou em névoa, neve, águas de superfície, etc.) em lugar da $\mathrm{CI}$, cabe citar: o equipamento básico de CE-CCD pode ser produzido em uma fração do custo da cromatografia de íons, sendo mais propenso a miniaturização; não requer bombas e cilindros de alta pressão nem colunas caras; o consumo de eletrólito e a geração de efluentes são mínimos; as exigências de força são menores, como são o tamanho e o peso do instrumento; CE-CCD é mais fácil de transportar e usar em trabalhos de campo. Desta forma, possibilitando 
desenvolvimento futuro de sistemas de análises in situ, próximas do tempo real para deposição úmida, de forma automática, superando problemas de armazenamento e da deterioração da amostra.

A avaliação dos eletroferogramas das amostras coletadas em São Paulo durante o período de Maio 1997 a Março 1998 proporcionou a determinação dos íons majoritários em água de chuva. A qualidade dos resultados obtidos pode ser confirmada pelo excelente balanço entre os cátions e os ânions e da grande proximidade entre os valores das condutividades medidas e calculadas das concentrações iônicas.

Os íons com concentrações dominantes foram cloreto e amônio seguidos pelo cálcio, nitrato e o sulfato, com as concentrações VWM que variaram de 29 a $6 \mu \mathrm{mol} \mathrm{L} \mathrm{L}^{-1}$. Os fluxos dos íons na deposição úmida variaram de 2,5 a $0,35 \mathrm{~g} \mathrm{~m}^{-2} \mathrm{ano}^{-1}$; valores elevados, porém similares às estimativas anteriores em São Paulo, com presença constante de nitrato e algum declínio de sulfato, relacionado às mudanças na composição do combustivel e nas emissões veiculares.

Não foram observadas alterações significativas nas concentrações da maioria dos íons $\left(\mathrm{NH}_{4}^{+}, \mathrm{K}^{+}, \mathrm{Na}^{+}, \mathrm{NO}_{3}{ }^{-} \mathrm{e} \mathrm{SO}_{4}{ }^{2-}\right)$ desde setembro 1993 a maio 1994 (Paiva et al., 1997), embora o cálcio mostrasse aumento, contribuindo para diminuição da acidez livre. 
CAPÍTULO VII - APLICAÇÃO DAS METODOLOGIAS DESENVOLVIDAS A OUTRAS MATRIZES 


\subsection{DETERMINAÇÃO DE ESPÉCIES DE S(IV) EM AMOSTRAS DE VINHO POR INJEÇÃO EM FLUXO COM DETECÇÃO AMPEROMÉTRICA EM GOTA PENDENTE DE MERCÚRIO}

Em sua dissertação de mestrado, Rocha (1999), elaborou método amperométrico em fluxo para determinação de hidrogenossulfito e do aduto com formaldeído, hidroximetanosulfonato, HMS, em água de chuva.

Os ótimos resultados conseguidos permitiram vislumbrar extensão natural e relevante para a aplicação desta metodologia: a especiação de S(IV) $\left(\mathrm{HSO}_{3}{ }^{-}, \mathrm{SO}_{3}{ }^{2-}, \mathrm{SO}_{2}\right.$ e hidroxialcanossulfonato) em alimentos e bebidas, tais como o vinho.

Os métodos analíticos disponíveis para a determinação de sulfito em vinho são diversificados, servindo de exemplo: destilação seguida de titulação iodométrica, espectrofotometria, quimioluminescência, potenciometria e cromatografia. Estes métodos não conseguem, a um só tempo, elevada seletividade com especiação das diferentes formas, alta freqüência analítica e baixo custo.

Assim, como um complemento ao plano original, considerou-se oportuno, trazer os progressos conseguidos na especiação de S(IV) em água de chuva para desenvolver método para determinação de $\mathrm{SO}_{2}$, sulfito livre e total em amostras de vinho em fluxo com detecção amperométrica. 


\subsubsection{CONSIDERAÇÕES GERAIS SOBRE ESPÉCIES DE S(IV) EM AMOSTRAS DE VINHO}

Atualmente, estima-se que no Brasil a produção de vinho seja aproximadamente de 210 milhões de litros anuais e a importação alcance cerca de US\$ 43 milhões.

A elaboração do vinho provavelmente foi introduzida há 7.000 ou 8.000 anos, no Oriente Médio. Durante vários séculos tentativas foram feitas para conservar a bebida. Os gregos, por exemplo, misturavam água do mar, ervas ou mel a seus vinhos para ajudar a conservá-lo ou disfarçar o sabor. A introdução dos tonéis de madeira, atribuída aos gauleses, produziu transformações nos métodos de produção e conservação. Somente no século XVII, garrafas de vidro possibilitaram melhoras na conservação e transporte.

Usualmente, sulfito é utilizado como conservante em alimentos e na indústria farmacêutica, para inibir a proliferação de bactérias e prevenir a oxidação (Coker, 1986; Moylan et al., 1986). Imprescindivel à boa conservação dos alimentos e das bebidas, como o vinho, as concentrações de aditivos devem ser controladas, para que se situem na faixa que garanta o efeito desejado mas ainda não ofereça riscos à saúde humana. $O$ excesso de sulfito pode produzir aroma e gosto desagradáveis, bem como ser prejudicial à saúde. Desta forma, o uso de sulfito como aditivo é regulamentado. No vinho distinguem-se as formas de $\mathrm{HSO}_{3}^{-}, \mathrm{SO}_{3}{ }^{2-}, \mathrm{SO}_{2}$ livres (não combinadas) e $\mathrm{HSO}_{3}^{-}$combinado, que está principalmente na forma de aduto com acetaldeído, o HAS (Figura 7.1.1.1). 


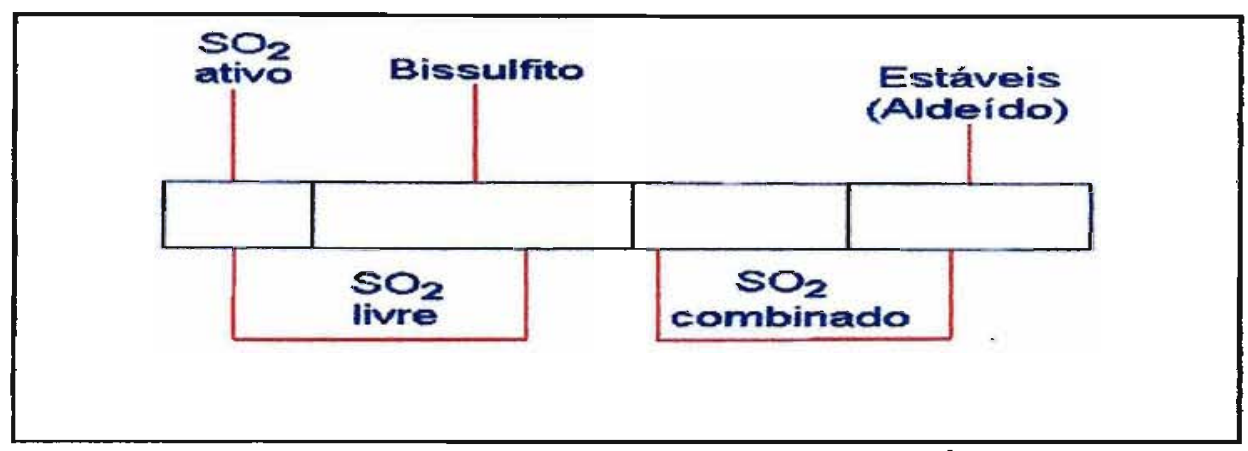

Figura 7.1.1.1 Representação das espécies de enxofre IV em amostras de vinho

No Brasil, são considerados aceitáveis, níveis em torno de 50 e 200 ppm para $\mathrm{SO}_{2}$ livre e adutado, respectivamente (Normas de Qualidade para Alimentos, 1976).

Para a determinação de $\mathrm{SO}_{2}$ em vinho, o método de referência adotado baseia-se na destilação da amostra com fluxo de nitrogênio, seguido de fixação e oxidação do $\mathrm{SO}_{2}$ em solução de $\mathrm{H}_{2} \mathrm{O}_{2}$ produzindo ácido sulfúrico. Posteriormente, efetua-se titulação com solução padrão de $\mathrm{NaOH}$ (Araújo et al., 1998; Azevedo et al., 1999).

Outro método recomendado é o iodométrico, utilizado preferencialmente pelas indústrias; porém, apresenta pouca seletividade e problemas de observação do ponto final, particularmente com amostras de vinho tinto. 
Embora, esses métodos sejam amplamente utilizados, demandam longos períodos de análise e apresentam pouca seletividade e sensibilidade. Conseqüentemente, necessita-se de métodos rápidos e simples para determinação de sulfito em vinho.

O desenvolvimento de sistemas de análise por injeção em fluxo (FIA) tem aumentado nas últimas décadas, principalmente pelo seu potencial no controle de qualidade, devido a simplicidade e alta freqüência analítica.

Assim, sistemas FIA têm sido aplicados à determinação de espécies de enxofre (IV) em amostras de vinho utilizando detecção espectrofotométrica (Sullivam et al., 1986; Brown et al., 1987), eletroquímica (Fogg et al., 1985; Marshall et al., 1983; Granados et al., 1986; Matzumoto et al., 1989; Azevedo, et al., 1999) e quimioluminescência (Yamada et al., 1983).

Dentre os sistemas FIA, para melhorar a seletividade, muitos utilizamse de unidades de difusão gasosa (GDU) através de uma membrana semipermeáve para coleta de $\mathrm{SO}_{2}$ contido na amostra de vinho. (Linares et al., 1989; Zhi et al., 1995; Azevedo et al., 1999). 


\subsubsection{DETERMINAÇÃO POLAROGRÁFICA DE $\mathrm{HSO}_{3}^{-}$}

Tal como o peróxido de hidrogênio, o sulfito também pode ser reduzido sobre o eletrodo de mercúrio, num processo cinético envolvendo dois elétrons:

$$
2 \mathrm{SO}_{2} \cdot \mathrm{H}_{2} \mathrm{O}+3 \mathrm{H}^{+}+4 \mathrm{e}^{-} \rightleftarrows \mathrm{HS}_{2} \mathrm{O}_{3}^{-}+\mathrm{H}_{2} \mathrm{O}
$$

Segundo Heyrovisky, o $\mathrm{SO}_{2}$ se reduz sobre a superficie de eletrodo de calomelano em potenciais de $-0,42 \mathrm{~V}$ para $\mathrm{pH} 1,87$ e $-0,56$ para $\mathrm{pH}$ de 3,80 , num processo envolvendo dois elétrons. Já o processo de oxidação (a sulfato), não pode ser alcançado sem que ocorra a oxidação do mercúrio.

A polarografia com amostragem de corrente contínua (DCT), mostrouse apropriada para a determinação analítica do sulfito, pelo processo de redução. Inicialmente, foram feitos estudos polarográficos (Figura 7.1.1.1) com o sulfito utilizando o polarógrafo Polarecord modelo E 506 da Metrohm Herisau, conectado a uma célula eletroquímica modelo 663 VA Stand da Metrohm (Figura 5.3.2). A Figura 7.1.1.2 mostra a curva de referência dos polarogramas obtidos, demonstrando boa linearidade.

Tais estudos, apontaram para a melhor reversibilidade da onda de redução do sulfito em $\mathrm{pH}$ em torno de 5, com eletrólito suporte de HAc/Ac$0,1 / 0,1 \mathrm{~mol} \mathrm{~L}^{-1}$, velocidade de varredura de $1,25 \mathrm{mV} \mathrm{s}^{-1}$, tempo de gotejamento de $0,8 \mathrm{~s}$ e varredura de $-0,5 \mathrm{a}-0,8 \mathrm{~V}$. 


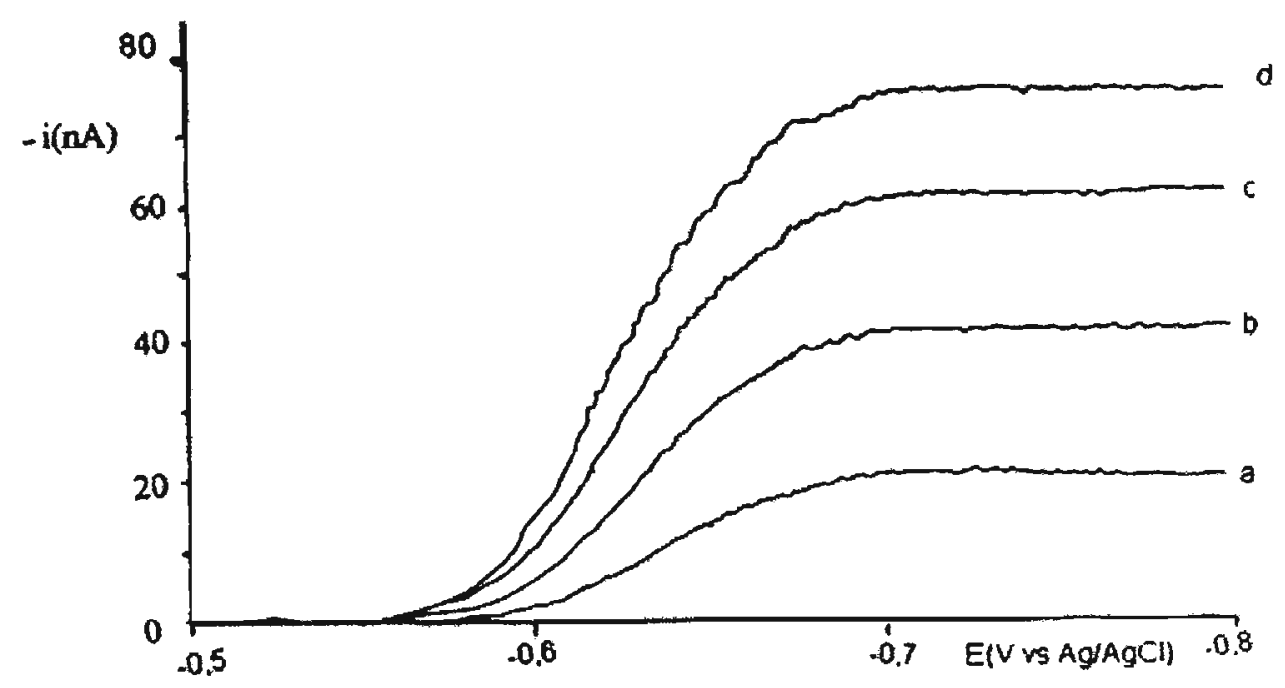

Figura 7.1.1.1 Polarogramas de sulfito, em pH 5 tamponado com solução de HAC/Ac- 0,1/0,1 mol L $\mathrm{L}^{-1}$. Concentrações: a- 10; b- 19; c- 29; d- $39 \mu \mathrm{mol} \mathrm{L} \mathrm{L}^{-1}$, velocidade de varredura de $1,25 \mathrm{mV} \mathrm{s}^{-1}$, tempo de gotejamento de $0,8 \mathrm{~s}$.

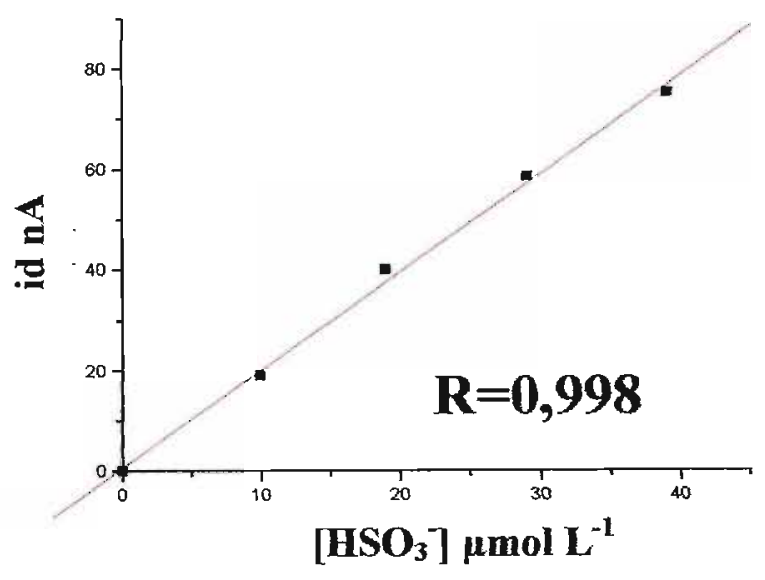

Figura 7.1.1.2 Curva de referência, de sulfito, relativa a Figura 7.1.1.1. 
Ainda durante o decorrer do mestrado, desenvolveu-se um dispositivo simples que permitiu a adaptação da célula estacionária (utilizada no estudo acima mencionado) com o eletrodo de gota de mercúrio, usado como gota pendente (EGPM) ou gota estática renovável (EGEM), para operação em fluxo. O dispositivo foi detalhado no Capítulo V (Figuras 5.4.1. e 5.4.2).

Outro aspecto importante é o de que o o oxigênio dissolvido é eletroativo na faixa de potencial apropriada à determinação do sulfito, seja estacionária, seja em fluxo, tornando necessária a sua remoção.

Desta forma, desenvolveu-se um eficiente dispositivo para desoxigenação em fluxo a partir de algumas modificações efetuadas em desoxigenador previamente construído. Além de pequenas adaptações, inovou-se em sua construção ao incluir mais uma via de fluxo e um dispositivo para convergência das linhas de fluxo, dentro do desoxigenador. $\mathrm{O}$ desoxigenador (Figura 5.5.1) é o mesmo utilizado na determinação de peróxido de hidrogênio em sistema FIA e encontra-se descrito no Capítulo V.

Ultrapassadas as dificuldades para análise em fluxo do sulfito, o sistema foi adaptado para a determinação das espécies de S(IV) em amostras de vinho.

Cabe ressaltar, que para determinação de espécies de $\mathrm{S}(\mathrm{IV})\left(\mathrm{SO}_{2}\right.$ e $\mathrm{HSO}_{3}{ }^{-}$livre e adutado) em amostras de vinho foram feitas várias adaptações no sistema FIA-Amperométrico desenvolvido originalmente (Rocha, 1999), gerando três sistemas FIA-Amperométrico distintos, os quais serão apresentados a seguir. 


\subsubsection{DETERMINAÇÃO AMPEROMÉTRICA EM FLUXO DE $\mathrm{HSO}_{3}{ }^{-}$LIVRE EM AMOSTRAS DE VINHO}

A técnica amperométrica com a qual se obteve os melhores resultados foi a DC com eletrodo de gota pendente, sendo a gota de mercúrio renovada a cada nova injeção de amostra ou padrão.

Embora os estudos iniciais, acima citados, tenham indicado que a melhor reversibilidade da onda de redução do sulfito seja em $\mathrm{pH}$ em torno de 5, com eletrólito suporte de $\mathrm{HAc} / \mathrm{Ac}^{-} 0,1 / 0,1 \mathrm{~mol} \mathrm{~L}^{-1}$; nos sistemas FIA desenvolvidos optou-se por utilizar tampão de $\mathrm{H}_{3} \mathrm{PO}_{4} / \mathrm{H}_{2} \mathrm{PO}_{4}{ }^{-} \quad 0,9 / 0,216 \mathrm{~mol}$ $\mathrm{L}^{-1}$, com $\mathrm{pH}$ em torno de 1,2. Desta forma, pode-se evitar o inconveniente do uso de vários tampões, passando-se a utilizar um único tampão para a determinação de $\mathrm{HSO}_{3}{ }^{-}$livre e adutado nos dois sistemas FIA desenvolvidos. Apesar da onda de redução ser menos reversível em pHs baixos $(1,2)$, acarretando perda de sensibilidade, houve compensação suficiente através da sensibilidade alcançada pelo método FIA-Amperométrico para determinação de espécies de enxofre (IV) em amostras de vinho.

Assim, para a determinação do sulfito livre em amostras de vinho o método consiste de um sitema em fluxo com duas vias; uma para água deionizada, que é utilizada como transportador do analito em uma vazão de $1,1 \mathrm{ml} \mathrm{min}{ }^{-1}$ e outra para o eletrólito, um tampão de $\mathrm{H}_{3} \mathrm{PO}_{4} / \mathrm{H}_{2} \mathrm{PO}_{4}^{-}$, com uma vazão de $0,15 \mathrm{ml} \mathrm{min}^{-1}$ (Figura 7.1.3.1).

$\mathrm{O}$ potencial aplicado foi de $-0,8 \mathrm{~V}$ vs $\mathrm{Ag} / \mathrm{AgCl}$, registrando-se a corrente catódica do $\mathrm{SO}_{2}$. 


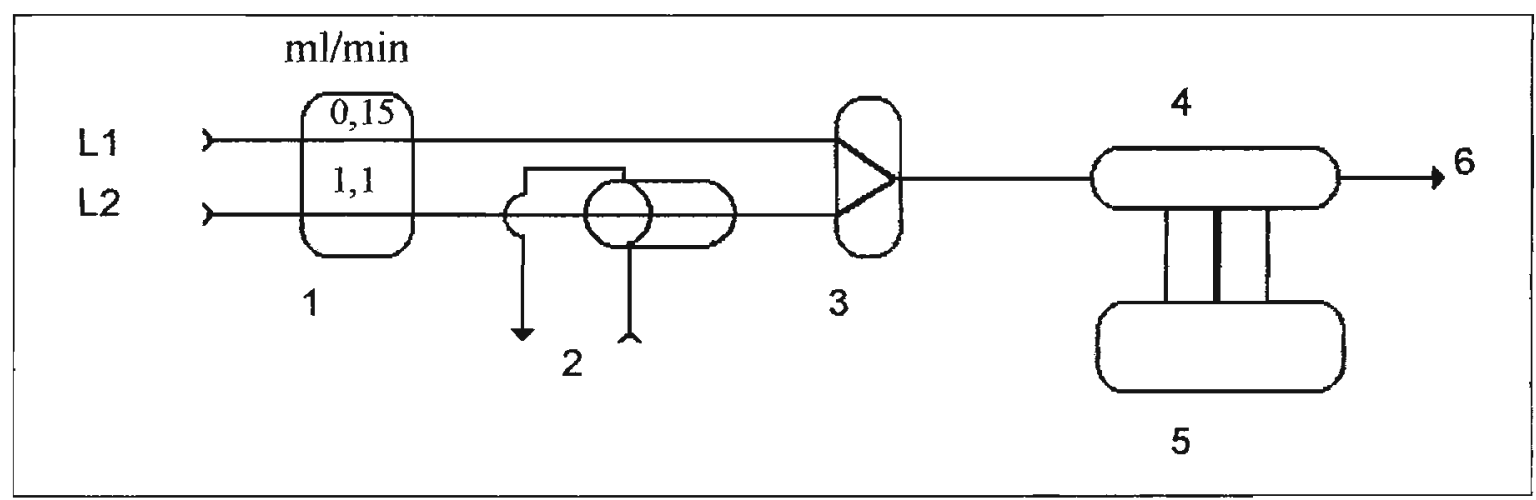

Figura 7.1.3.1 Esquema de Sistema FIA para análise de $\mathrm{HSO}_{3}^{-}$, em amostra de vinho: 1- Bomba peristáltica; 2- Injetor- alça de amostragem $400 \mu \mathrm{L}$; 3Desoxigenador; 4- Célula eletroquímica; 5- Potenciostato/Registrador; 6Descarte, $\mathrm{L} 1$ - Linha de fluxo para eletrólito suporte (tampão de $\mathrm{H}_{3} \mathrm{PO}_{4} / \mathrm{H}_{2} \mathrm{PO}_{4}{ }^{-}$ 0,9 e $0,216 \mathrm{~mol} \mathrm{~L}^{-1}$ ), L2- Linha de fluxo para transportador (água deionizada), $\mathrm{E}=-0,8 \mathrm{~V}$.

Após a saída do desoxigenador o pH da solução está em torno de $1,2 \mathrm{e}$ o equilíbrio das espécies de S(IV) estará deslocado no sentido da formação de $\mathrm{SO}_{2}$, que será reduzido na célula eletroquímica.

Devido à complexidade da amostra, comparou-se os coeficientes angulares e os coeficientes de correlação determinados em curva de referência e pelo procedimento de adição de padrão, para a análise de $\mathrm{HSO}_{3}{ }^{-} \mathrm{em}$ amostras de vinho, visando detectar possíveis interferências de matriz. Para tanto, construiu-se uma curva de referência (Figura 7.1.3.2) com concentrações de $\mathrm{HSO}_{3}^{-}$variando de 0,2 a $0,8 \mathrm{mmol} \mathrm{L}^{-1}$, obtendo-se um coeficiente angular de $3,63 \mu \mathrm{A} / \mathrm{mmol} \mathrm{L}^{-1}(\mathrm{R}=0,998)$. Posteriormente, sobre amostra de vinho, efetuou-se adições de padrão de $20 \mu \mathrm{mol} \mathrm{L} \mathrm{L}^{-1}$ (Figura 7.1.3.3), cujo coeficiente angular ficou em torno de $3,45 \mu \mathrm{A} / \mathrm{mmol} \mathrm{L}^{-1}(\mathrm{R}=$ $0,994)$. 
Comparando-se a curva de referência e a curva de adição de padrão ambas efetuadas pelo método descrito, observa-se diferença pequena entre os coeficientes angulares, indicando que a amostra analisada não causa desvios devido às características da matriz. Tal constatação favorece o uso direto da curva de referência, acelerando a determinação (menos etapas).

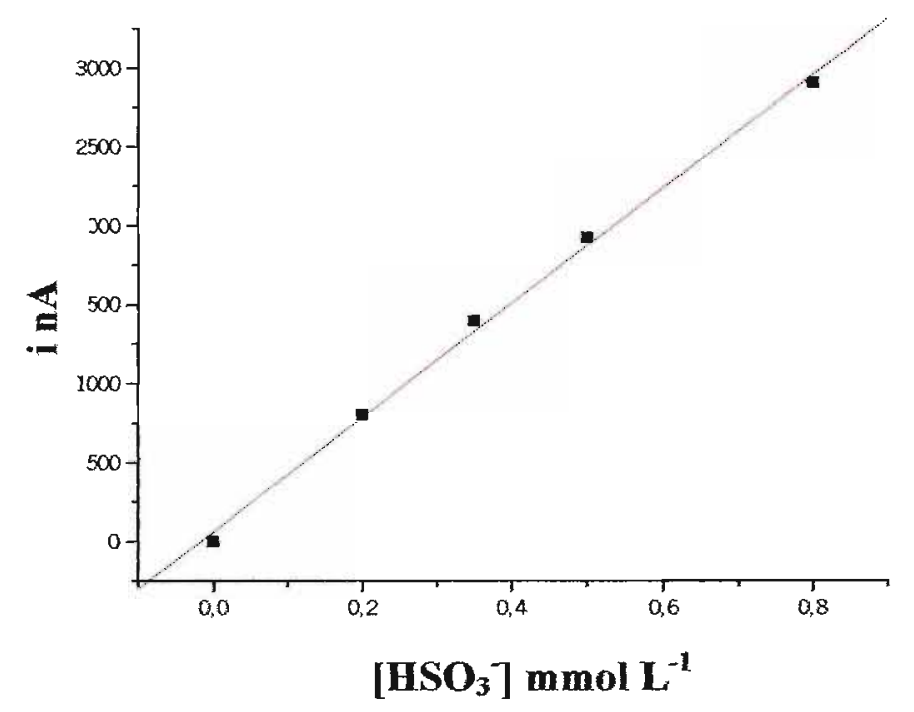

Figura 7.1.3.2 Curva de referência para análises de $\mathrm{HSO}_{3}{ }^{-} \mathrm{em}$ amostras de vinho. 


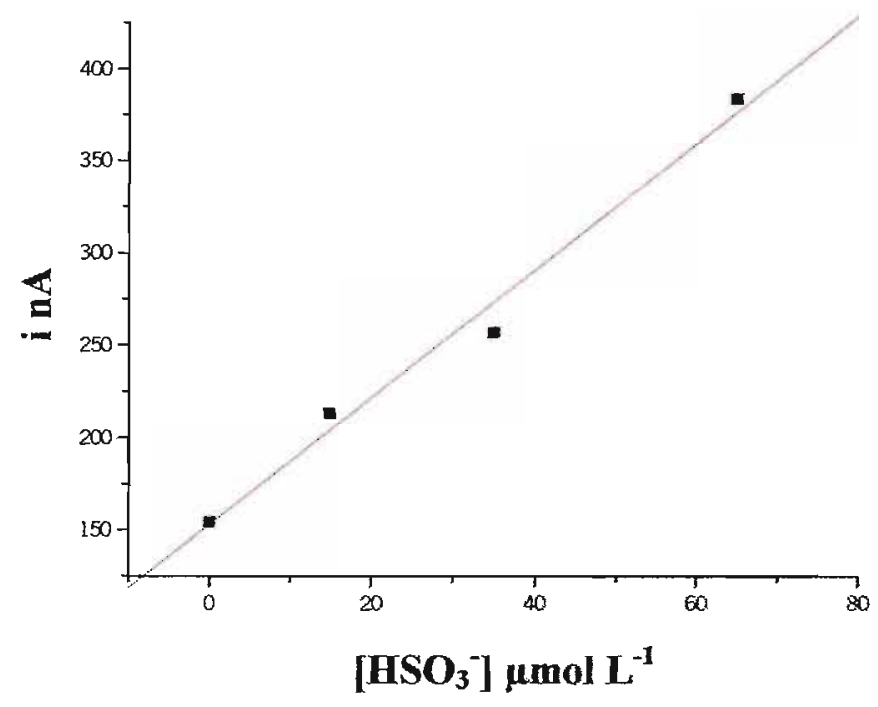

Figura 7.1.3.3 Adições de padrão de solução de $\mathrm{HSO}_{3}{ }^{-}$em amostras de vinho.

\subsubsection{UTILIZAÇÃO DE FORMALDEÍDO PARA GARANTIR SELETIVIDADE AO SINAL AMPEROMÉTRICO}

Para determinar seletivivamente $\mathrm{o}^{\mathrm{HSO}_{3}}{ }^{-}$frente a outros eventuais interferentes eletroativos presentes nas complexas amostras de vinho, recorreu-se à medição amperométrica diferencial, antes e depois da adição de excesso de formaldeído às amostras, visto que este reage com o $\mathrm{HSO}_{3}^{-}$, com 
formação de HMS (Tabela 4.1.4.1), eletroinativo no potencial de trabalho aplicado, conforme demonstrado a seguir.

Inicialmente, uma alíquota de vinho é injetado no sistema, onde o sinal amperométrico do $\mathrm{SO}_{2}$ poderá ser registrado em potencial adequado. Uma segunda alíquota do vinho acrescida de $\mathrm{CH}_{2} \mathrm{O}$, até concentração de aproximadamente cem vezes a quantia aparente da concentração de $\mathrm{SO}_{2}$, é injetada no sistema registrando-se o sinal amperométrico.

Portanto, a concentração de $\mathrm{SO}_{2}$ será proporcional à diferença das alturas dos picos nas amostras, com e sem formaldeído.

Para exemplificar a utilização do $\mathrm{HCHO}$ para mascarar o $\mathrm{HSO}_{3}^{-}$, a Figura 7.1.3.2 apresenta sinais amperométricos de $\mathrm{HSO}_{3}^{-}$livre em vinho na concentração de $0,3 \mathrm{mmol} \mathrm{L}^{-1}$ e sinais amperométricos da mesma solução de $\mathrm{HSO}_{3}^{-}$livre em vinho acrescida de $2 \mathrm{mmol} \mathrm{L}{ }^{-1}$ de $\mathrm{CH}_{2} \mathrm{O}$. A diferença da altura dos picos é proporcional a concentração de $\mathrm{HSO}_{3}{ }^{-}$livre encontrada no vinho. O sinal amperométrico residual provavelmente deve-se a outras espécies eletroativas nesse potencial encontradas em vinho e não determinadas neste trabalho. 


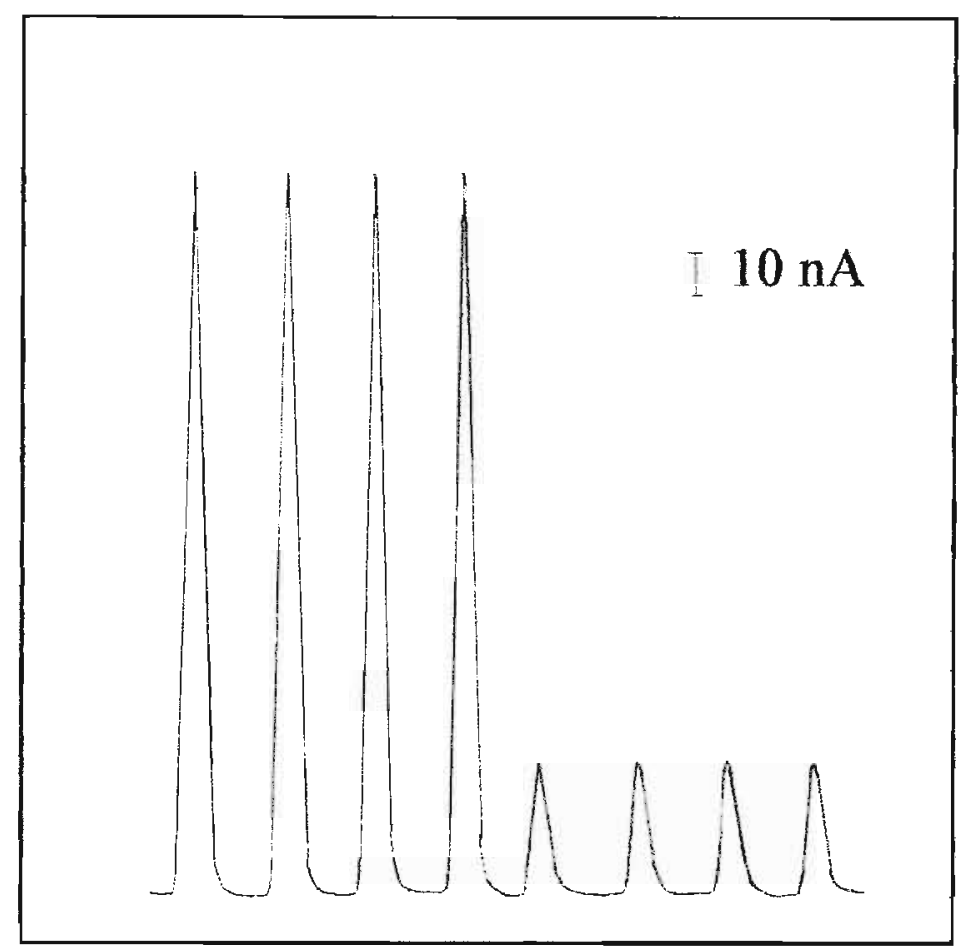

Figura 7.1.3.1.1 Sinais amperométricos de sulfito livre em vinho na soncentração de $0,3 \mathrm{mmol} \mathrm{L} \mathrm{L}^{-1}$ e com adição de formaldeído na concentração de $2 \mathrm{mmol} \mathrm{L}^{-1}$ na amostra.

\subsubsection{DETERMINAÇÃO AMPEROMÉTRICA EM FLUXO DE $\mathrm{HSO}_{3}{ }^{-}$TOTAL EM AMOSTRAS DE VINHO}

Como já comentado anteriormente, os adutos formados entre $\mathrm{HSO}_{3}{ }^{-} \mathrm{e}$ aldeídos se decompõe em meio alcalino. Desta forma, desenvolveu-se um sistema FIA-Amperométrico, similar ao descrito anteriormente, incluindo-se 
uma via de fluxo para alcalinização da amostra de vinho, visando a decomposição dos adutos formados e conseqüentemente a determinação do $\mathrm{HSO}_{3}{ }^{-}$total.

O sistema em fluxo para determinação de sulfito total (Figura 7.1.4.1) consiste de três vias de fluxo, sendo uma para o eletrólito suporte, um tampão de $\mathrm{H}_{3} \mathrm{PO}_{4} / \mathrm{H}_{2} \mathrm{PO}_{4}^{-} \quad 0,9$ e $0,216 \mathrm{~mol} \mathrm{~L}^{-1}$ sob vazão de $0,15 \mathrm{~mL} \mathrm{~min}$ min $^{-1}$ (L1), outra para $\mathrm{NaOH} 10 \mathrm{mmol} \mathrm{L}^{-1}$ com vazão de $0,5 \mathrm{~mL} \mathrm{~min}^{-1}$ (L2) e uma terceira via para água deionizada com vazão de $0,5 \mathrm{~mL} \min ^{-1}(\mathrm{~L} 3)$, utilizada como transportador da amostra.

No sistema FIA, inicialmente a amostra é injeta e alcalinizada até pH próximo a 12,3 na confluência de L2 com L3 (Figura 7.1.4.1). Neste ponto, praticamente todo o $\mathrm{HSO}_{3}^{-}$é convertido a $\mathrm{SO}_{3}^{2-}$, atravessando o desoxigenador sem que ocorram perdas na concentração de $\mathrm{SO}_{3}{ }^{2-}$ e sem a formação de adutos. Posteriormente, na saída do desoxigenador ocorre a confluência com L1 e o meio ficará ácido $(\mathrm{pH}=1,2)$. Neste meio, a recombinação de sulfito e aldeídos, formando adutos, ocorre de forma mais lenta, proporcionado tempo suficiente para a deteç̧ão do $\mathrm{SO}_{2}$. 


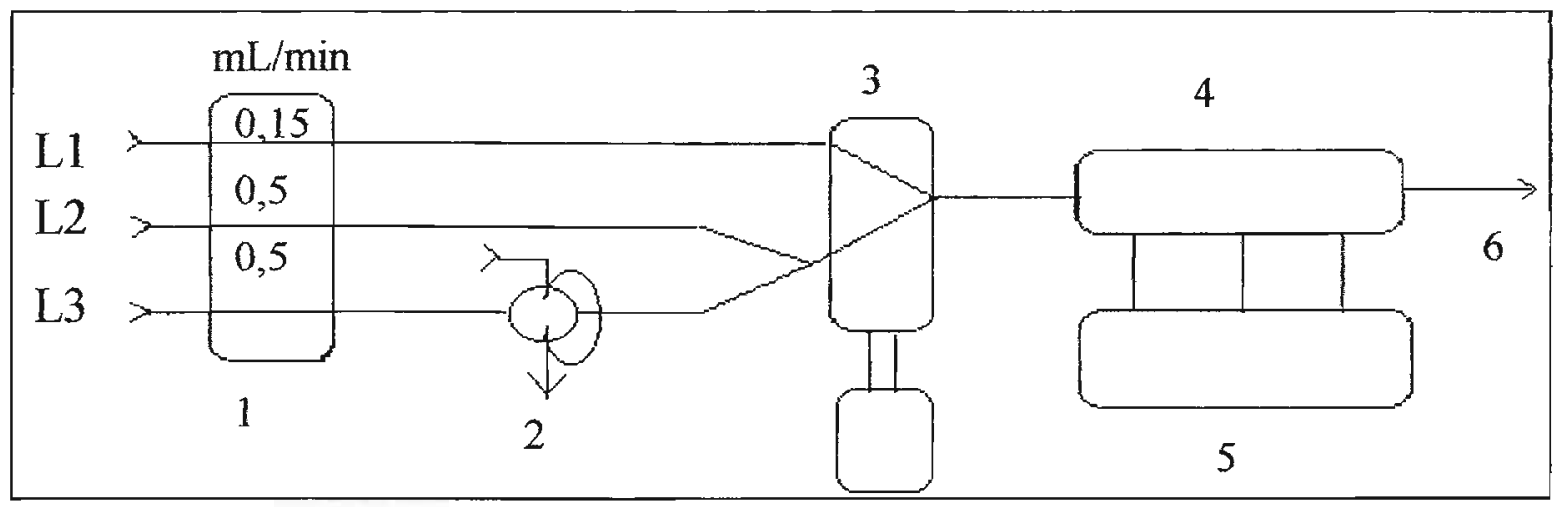

Figura 7.1.4.1 Sistema FIA para determinação de sulfito em vinho 1- Bomba peristáltica; 2- Injetor; 3- Desoxigenador e bomba de vácuo; 4- Célula eletroquimica; 5- Potenciostato/Registrador; 6- Descarte; L1- Linha de fluxo para eletrólito suporte de $\mathrm{H}_{3} \mathrm{PO}_{4} / \mathrm{H}_{2} \mathrm{PO}_{4}^{-} \quad 0,9$ e $0,216 \mathrm{~mol} \mathrm{~L}^{-1}$; L2- Linha para $\mathrm{NaOH} 10 \mathrm{mmol} \mathrm{L}^{-1}$; L3 -Água deionizada.

\subsubsection{DETERMINAÇÃO DE $\mathrm{SO}_{2}$ EM AMOSTRAS DE VINHO EM FLUXO}

$\mathrm{Na}$ determinação de $\mathrm{SO}_{2}$, foi utilizado um sistema com duas vias (Figura 7.1.5.1); uma para água desionizada que é utilizada como transportador do analito (vinho) em uma vazão de $1,1 \mathrm{ml} \mathrm{min}^{-1}$ e outro para o fluxo aceptor, também com uma vazão de $1,1 \mathrm{ml} \mathrm{min}^{-1}$. As duas linhas de fluxo atravessam uma unidade de difusão gasosa (GDU) feita em acrílico, com dimensões de $35 \times 47 \times 165 \mathrm{~mm}$, na qual foram feitos dois canais internos separados por uma membrana de Teflon ${ }^{(\mathbb{k})}$ permeável a gases, para que ocorra transferência do $\mathrm{SO}_{2}$ do fluxo doador para o fluxo aceptor.

Selecionou-se tampão de $\mathrm{HAc} / \mathrm{Ac}^{-}$de $\mathrm{pH} 4,7$, vez que neste $\mathrm{pH}$ o $\mathrm{SO}_{2}$

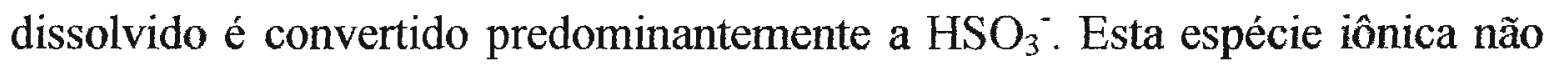


volátil não é perdida durante o processo de remoção do oxigênio que se segue. Esta solução tampão também serve como eletrólito para a amperometria, como já visto, além de neste valor de $\mathrm{pH}$ haver boa reversibilidade do processo de redução no HMDE.

Dentro da GDU (Figuras 7.1.5.3 e 7.1.5.4), o $\mathrm{SO}_{2}$ difunde para o fluxo do eletrólito através da membrana de Teflon ${ }^{1}$. Após a passagem pela GDU, o fluxo com água deionizada será descartado, enquanto o fluxo do eletrólito passará pelo desoxigenador para remover o $\mathrm{O}_{2}$ dissolvido.

A partir do desoxigenador o fluxo do eletrólito segue em direção a célula eletroquímica à qual é aplicado o potencial de $-0,8$ V vs $\mathrm{Ag} / \mathrm{AgCl}$, registrando-se a corrente catódica do $\mathrm{SO}_{2}$.

Como exemplo da boa linearidade do sistema, a Figura 7.1.5.2 apresenta uma curva de referência para $\mathrm{SO}_{2}$ em amostra de vinho utilizando a unidade de difusão gasosa em sistema FIA.

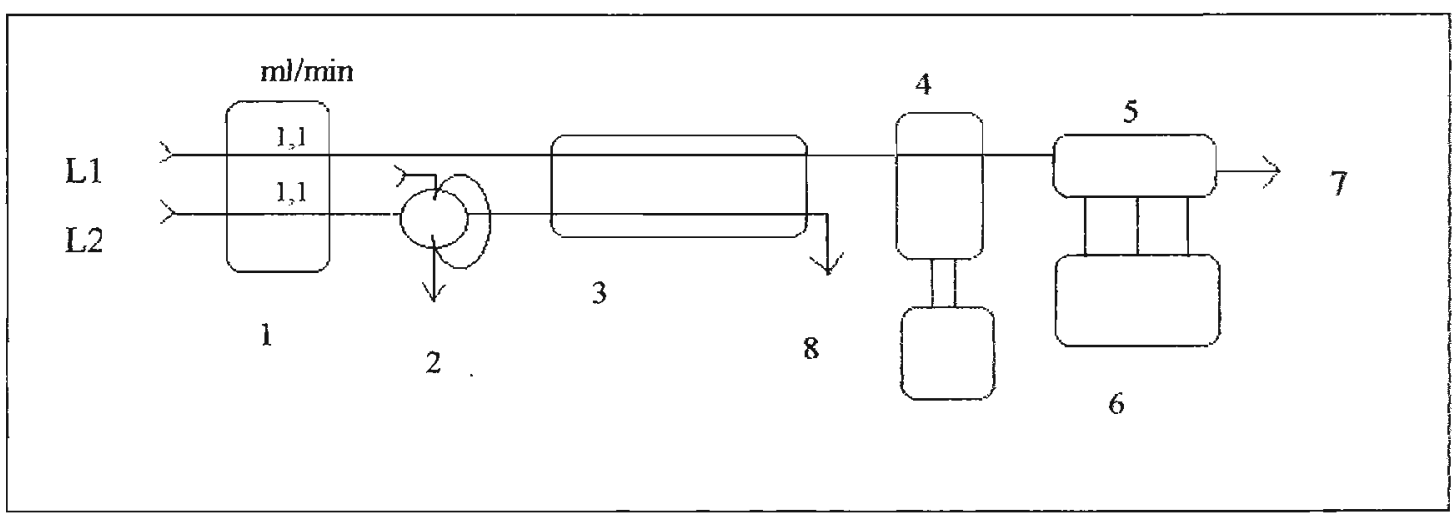

Figura 7.1.5.1 Sistema FIA 1- Bomba peristáltica; 2- Injetor; 3- Unidade de difusão gasosa; 4- Desoxigenador e bomba de vácuo; 5- Célula eletroquímica; 6- Potenciostato/Registrador; 7 e 8 - Descarte; L1- Linha de fluxo para eletrólito suporte Hac/Ac- $10 / 10 \mathrm{mmol} \mathrm{L}^{-1} ; \mathrm{E}=-0,8 \mathrm{~V}$. 


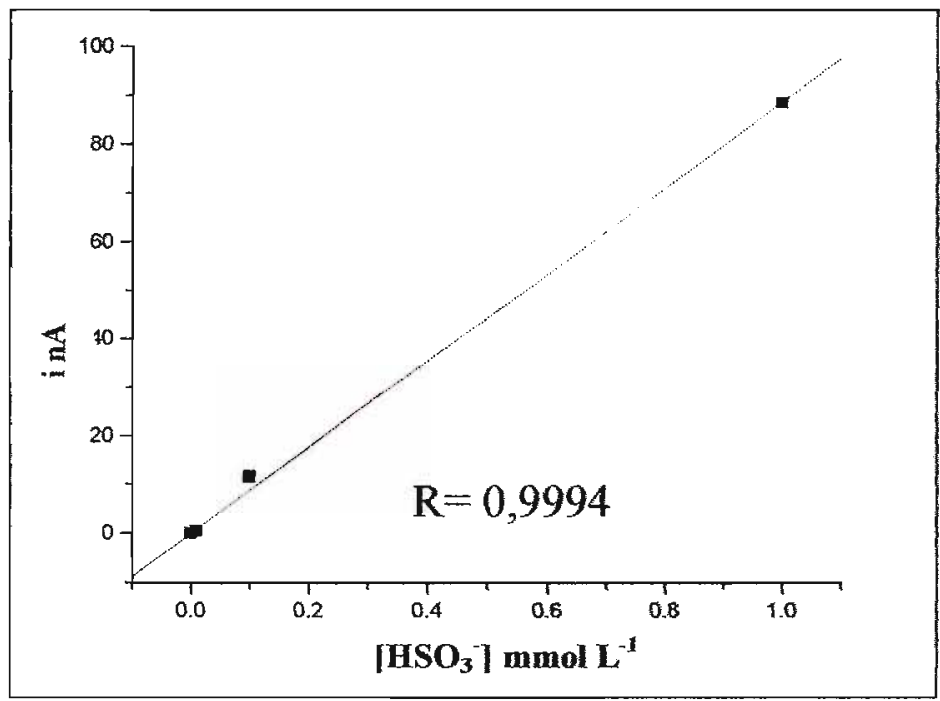

Figura 7.1.5.2 Curva de referência para $\mathrm{SO}_{2}$, utilizando o sistema em fluxo descrito.
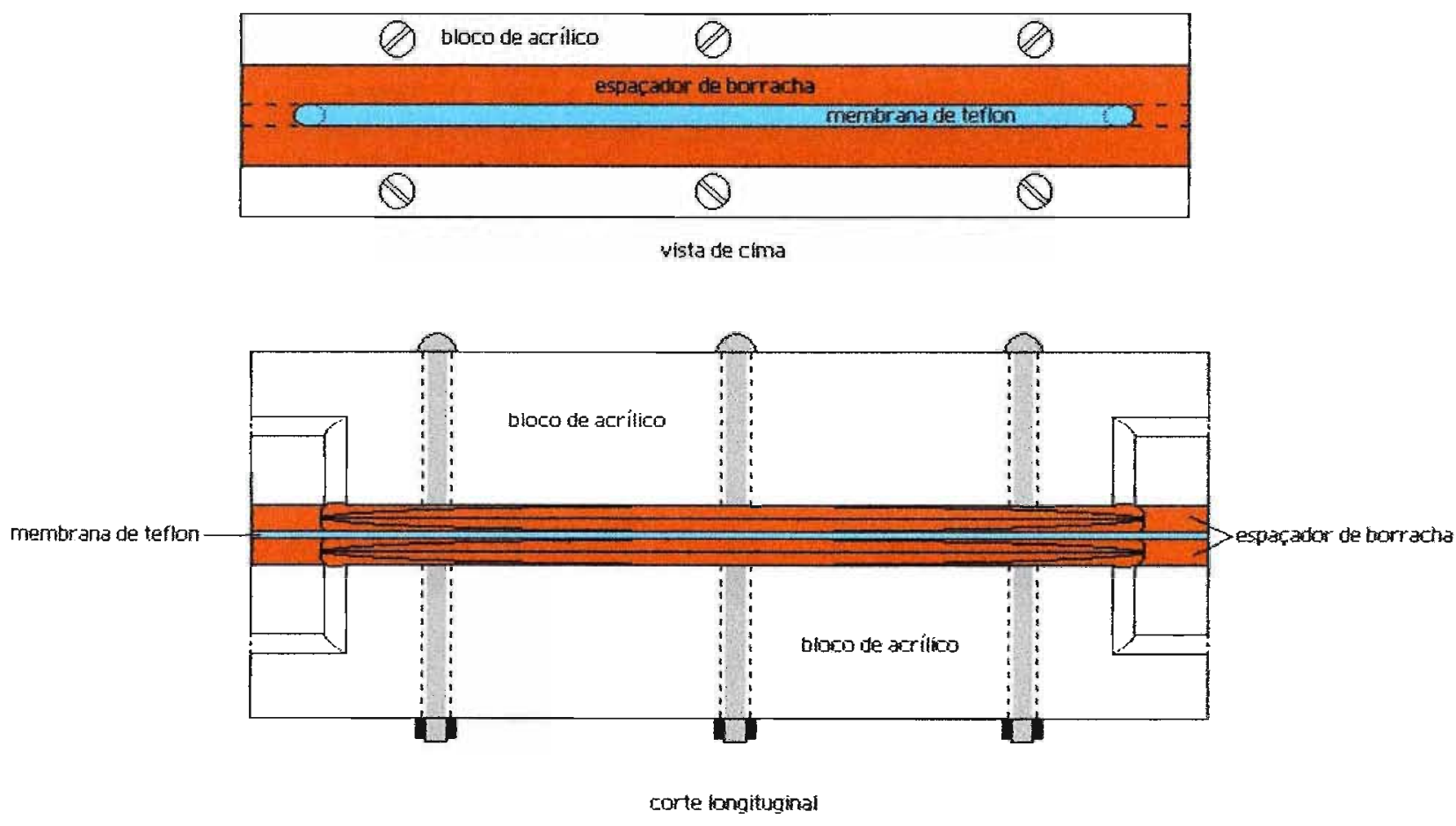

Figuras 7.1.5.3 Vista superior e lateral da unidade de difusão gasosa ( $35 \times 47$ x $165 \mathrm{~mm}$ ) 


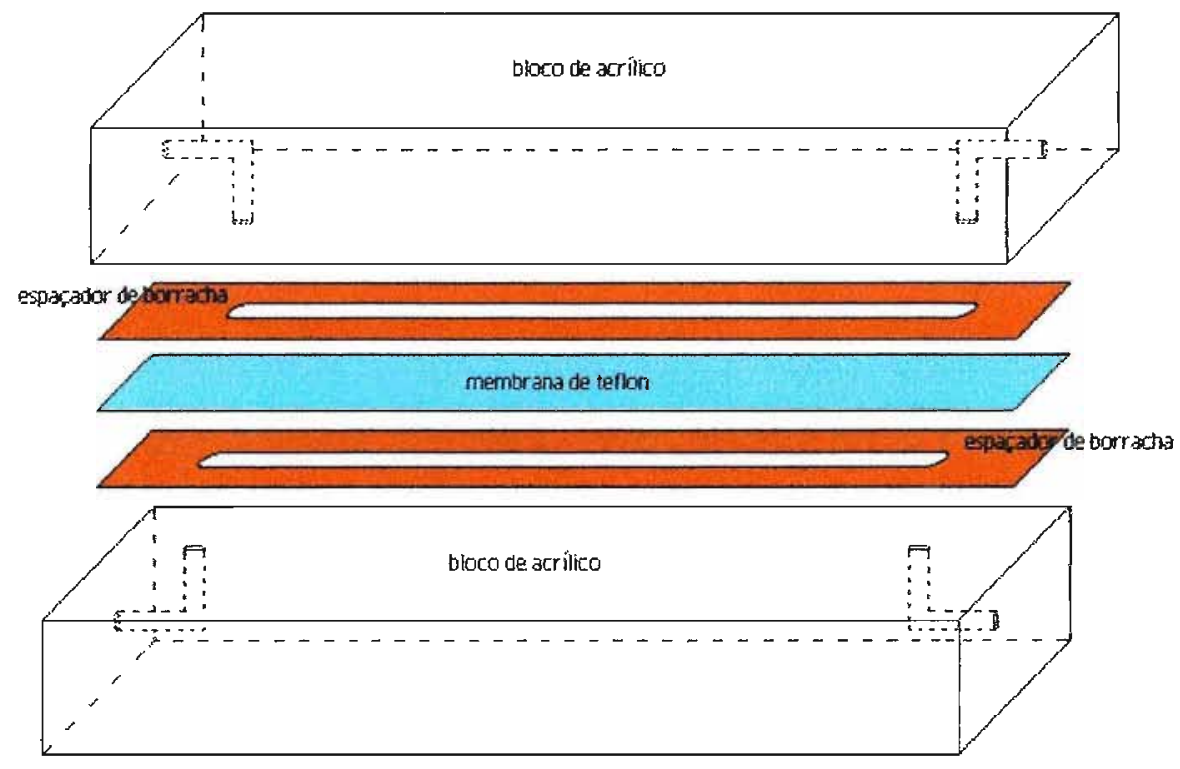

Figuras 7.1.5.4 Desenho expandido da unidade de difusão gasosa com membrana Teflon ${ }^{(2)}$. 


\subsubsection{RESULTADOS E DISCUSSÃO}

$\mathrm{O}$ método mostrou-se eficiente para a determinação de $\mathrm{HSO}_{3}^{-}$livre e adutado e de $\mathrm{SO}_{2}$ em amostras de vinho, ficando a freqüência analítica em torno de 60 determinações/hora, numa faixa linear de $0,1 \mu \mathrm{mol} \mathrm{L} \mathrm{L}^{-1}$ a $1 \mathrm{mmol}$ $\mathrm{L}^{-1}$. O limite de detecção foi estimado em $0,1 \mu \mathrm{mol} \mathrm{L} \mathrm{L}^{-1}$.

A Tabela 7.1.6.1 mostra as concentrações de S(IV) em algumas amostras de vinho tinto, branco e rose.

Tabela 7.1.6.1 Análise de $\mathrm{HSO}_{3}{ }^{-}$livre, total e de $\mathrm{SO}_{2}$ em vinhos

\begin{tabular}{|l|c|c|}
\hline VINHOS & $\mathrm{HSO}_{3}^{-}$livre / $\mathbf{~ m m o l ~ L}^{-1}$ & $\mathbf{H S O}_{3}^{-}$ \\
\hline Forrestier Tinto & 0,34 & 1,36 \\
\hline Forrestier Branco & 0,3 & 0,91 \\
\hline Almaden Tinto & 0,25 & 1,13 \\
\hline Almaden Branco & 0,32 & 0,76
\end{tabular}

\section{VINHOS}

Chalise Rose

\section{$\mathrm{SO}_{2} \mathrm{mmol} \mathrm{L}^{-1}$}

0,55

0,36

A metodologia desenvolvida para determinação de S(IV) em amostras de vinho, mostrou-se rápida, sensível e simples. 
Como anteriormente comentado, o método referência para análise de sulfito em vinho envolve destilação da amostra com fluxo de nitrogênio, seguido de fixação e oxidação do $\mathrm{SO}_{2}$ em solução de $\mathrm{H}_{2} \mathrm{O}_{2}$ e titulação do ácido sulfúrico produzido com solução padrão de $\mathrm{NaOH}$, demandando longo períodos de análises; além do que, não possibilita a determinação de todas as espécies de $\mathrm{S}(\mathrm{IV})$ presentes na amostra. Também, o método iodométrico apresenta algumas desvantagens; entre elas, a pouca seletividade e dificuldades na visualização do ponto final da titulação para vinho tintos.

O método proposto nesta tese elimina as desvantajosas etapas de destilação e titulação, demonstrando freqüência analítica muito apropriada para controle de qualidade.

O sistema FIA descrito é de fácil e rápida montagem, utilizando apenas material de fácil comercialização como tubos de silicone, membrana de Teflon ${ }^{\text {, }}$, acrílico e ponteiras descartáveis, envolvendo baixo custo agregado.

Além de possibilitar a determinação de todas as espécies de S(IV) em amostras de vinho com simples e rápida alteração dos sistemas FIA, a metodologia proposta pode ser facilmente automatizada.

Ainda, devido a natureza da amostra, o eletrodo renovável de mercúrio elimina o problema da "limpeza" dos eletrodos sólidos decorrente da sua apassivação e a delicada etapa de construção dos eletrodos modifícados. Aliás, via de regra, para evitar os problemas apontados para os eletrodos sólidos, praticamente todos os autores recorrem ao uso de uma GDU, incrementando desta forma, também, a seletividade (Azevedo, et al., 1999). 


\subsection{DETERMINAÇÃO DE $\mathrm{H}_{2} \mathrm{O}_{2}$ EM EFLUENTES E ÁGUA DE CULTIVO DE Daphnia Similis APÓS IRRADIAÇÃO COM FEIXES DE ELÉTRONS}

É bem sabido que o impacto ambiental de efluentes líquidos os mais diversos pode ocasionar problemas tão ou mais graves ao meio ambiente que a poluição atmosférica. Uma das diferenças é que a dispersão dos poluentes líquidos e, sobremaneira, os sólidos, é mais restrita geograficamente.

Entre os diversos métodos de tratamento de efluentes, a utilização de radiações ionizantes figura como alternativa promissora entre os métodos relativamente novos empregados na redução de toxicidade de efluentes (Borrely, 2001).

A energia proveniente da radiação ionizante ao interagir com a camada de efluentes, ou outro material qualquer, é redistribuída entre os átomos e moléculas que o constituem, produzindo, entre outras espécies, os radicais $\mathrm{H}^{*}$, $\mathrm{OH}^{\bullet}$ e $\mathrm{OH}_{2}{ }^{\bullet}$, altamente reativos. Os radicais, ao interagirem com as moléculas originando processos de óxido-redução, dissociação ou degradação, etc., promovem também a formação do peróxido de hidrogênio (Borrely, 2001).

Numa aparente contradição, após o processo de irradiação, os efluentes podem apresentar a esperada diminuição de toxicidade, enquanto água relativamente limpa, pode apresentar incremento na toxicidade, quando avaliada pela sua ação letal sobre microcrustáceos, em testes biológicos.

Suspeitava-se que este incremento na toxicidade poderia estar relacionado ao aumento da presença de $\mathrm{H}_{2} \mathrm{O}_{2}$ após o processo de irradiação, no caso de amostras relativamente limpas, sem suficiente material orgânico para ser oxidado. 
Surge desta forma, a possibilidade de estender a aplicação da metodologia desenvolvida (descrita no Capítulo V) para análise de $\mathrm{H}_{2} \mathrm{O}_{2}$ em águas de chuva e fase gasosa da atmosfera em sistema FIA, para a detecção de $\mathrm{H}_{2} \mathrm{O}_{2}$ em efluentes tratados pelo sistema de irradiação com feixes de elétrons, visando determinar a toxicidade resultante do sistema.

\subsubsection{DETERMINAÇÃO AMPEROMÉTRICA DE $\mathrm{H}_{2} \mathrm{O}_{2}$ POR INJEÇÃO EM FLUXO EM EFLUENTES E ÁGUA DE CULTIVO DE Daphnia Similis}

Atualmente, com a crescente legislação restritiva à poluição ambiental, inúmeras metodologias vem sendo desenvolvidas para o tratamento de resíduos e efluentes industriais.

Várias delas envolvem a adição de peróxido de hidrogênio como reagente ou coadjuvante na oxidação de matéria orgânica (POA, 2001); outras, como o tratamento com radiação de elétrons de alta energia, apresentam formação de $\mathrm{H}_{2} \mathrm{O}_{2}$ in situ, ao lado de outras espécies reativas.

O peróxido de hidrogênio, em concentrações superiores às encontrados no ambiente, pode ser tóxico a algumas espécies de fauna e de flora. Deste contexto surge a necessidade de uma técnica analítica para determinação de $\mathrm{H}_{2} \mathrm{O}_{2}$ rápida, sensível e seletiva e que possa funcionar em matrizes complexas como os efluentes industriais.

Em conjunto com um grupo de pesquisadores do IPEN que se dedica ao tratamento de efluentes por irradiação com elétrons, investigou-se a aplicabilidade do método de determinação de $\mathrm{H}_{2} \mathrm{O}_{2}$ por amperometria em fluxo com HMDE. $\mathrm{O}$ interesse residia em analisar $\mathrm{H}_{2} \mathrm{O}_{2}$ tanto nos efluentes irradiados como na água de cultivo do microcrustáceo utilizado no teste de toxicidade. 
Para ambas as matrizes, o método espectrofotométrico envolvendo formação de complexos coloridos de peróxido com vanadato apresentava limitações de sensibilidade e/ou seletividade, devido à complexidade dos efluentes.

As amostras de efluentes industriais e água de cultivo de Daphnia similis foram irradiadas no acelerador industrial de elétrons, tipo Dynamitron, com energia variável até $1,5 \mathrm{MeV}$, potência de $37,5 \mathrm{KW}$, variando-se a corrente para obter-se as diferentes doses necessárias para o estudo. $\mathrm{O}$ processamento por irradiação foi realizado em temperatura ambiente, sistema de batelada, onde as amostras foram acondicionadas em recipiente Pyrex de $250 \mathrm{~mL}$ no IPEN.

Após a irradiação, as amostras foram congeladas em gelo seco e acondicionadas. Posteriormente, as amostras foram transferidas para o Instituto de Química, descongeladas e as concentrações de $\mathrm{H}_{2} \mathrm{O}_{2}$ foram determinadas pelo método amperométrico em fluxo com eletrodo pendente de mercúrio.

Para tanto, recorreu-se a polarógrafo Polarecord e célula eletroquímica VA stand 663 da Metrohnm, adaptada para fluxo conforme descrito anteriormente, ficando o potencial de trabalho em -0,07 V vs $\mathrm{Ag} / \mathrm{AgCl}$.

O sistema em fluxo (Figura 5.6.1 Capítulo V) para determinação do $\mathrm{H}_{2} \mathrm{O}_{2}$ apresenta duas vias de fluxo, sendo uma para eletrólito suporte e outra para o transportador. O eletrólito suporte utilizado foi $\mathrm{NaOH}\left(11 \mathrm{mmol} \mathrm{L}^{-1}\right)$, obtido por mistura de $\mathrm{NaOH}\left(90 \mathrm{mmol} \mathrm{L}^{-1}\right)$ sob vazão de $0,15 \mathrm{~mL} \mathrm{~min}^{-1} \mathrm{com}$ água deionizada, em outra via de fluxo, a uma vazão de $1,1 \mathrm{~mL} \mathrm{~min}^{-1}$, ficando o pH em torno de 12 após a confluência.

A seletividade do $\mathrm{H}_{2} \mathrm{O}_{2}$ foi alcançada recorrendo-se a medidas diferenciais envolvendo exposição alternada à enzima catalase; primeiro injetando-se uma alíquota de amostra de efluente irradiado, em seguida 
injetando-se outra alíquota da mesma amostra acrescida de catalase, como já demonstrado anteriormente.

\subsubsection{RESULTADOS E DISCUSSÃO}

Segundo os pesquisadores do Centro de Tecnologia das Radiações do IPEN, o tratamento de efluentes com irradiação de elétrons reduz sensivelmente a toxicidade aguda destes. Porém, residia preocupação quanto aos subprodutos gerados.

Entre eles, a presença de $\mathrm{H}_{2} \mathrm{O}_{2}$ poderia ser crítica para os organismos teste. Assim, ao ser observada redução na toxicidade do efluente com a aplicação de irradiação era de se supor que não havia $\mathrm{H}_{2} \mathrm{O}_{2}$ residual. Entretanto, a irradiação da água de cultivo dos organismos testes (Daphnia similis) tornava-a tóxica.

Nesse aspecto, a metodologia desenvolvida neste doutoramento para determinação amperométrica de $\mathrm{H}_{2} \mathrm{O}_{2}$ em fluxo com , foi crucial para elucidar as dúvidas quanto a presença de $\mathrm{H}_{2} \mathrm{O}_{2}$ nas amostras irradiadas.

Desta forma, a detecção e quantificação de $\mathrm{H}_{2} \mathrm{O}_{2}$ pelo método amperométrico em amostras de água de cultivo irradiadas com feixe de elétrons aponta para o aumento de sua toxicidade ao ser irradiada e em amostra de efluentes irradiados a ausência de peróxido notada coincide com a diminuição de toxicidade.

A Tabela 7.2.2..1 mostra a concentração de $\mathrm{H}_{2} \mathrm{O}_{2}$ encontrada segundo a metodologia descrita (Capítulo V) em várias amostras de água de cultivo com dosagens crescente de irradiação. 
Nas amostras de efluentes irradiados, não foi detectado $\mathrm{H}_{2} \mathrm{O}_{2}$. Não se tratando de efeito de matriz, pois a adição de padrão $\mathrm{H}_{2} \mathrm{O}_{2}$ revelava o sinal de corrente esperado e este era novamente eliminado pela adição de catalase.

Tabela 7.2.2..1 Concentração de $\mathrm{H}_{2} \mathrm{O}_{2}$ em amostras de água de cultivo com dosagens crescente de irradiação por feixes de elétrons (kGy).

\begin{tabular}{|c|c|}
\hline $\mathbf{k G y}$ & {$\left[\mathbf{H}_{\mathbf{2}} \mathbf{O}_{2}\right] \boldsymbol{\mu m o l ~ \mathbf { L } ^ { - \mathbf { 1 } }}$} \\
\hline 0,5 & 23,77 \\
\hline 1,0 & 30,59 \\
\hline 1,0 & 35,46 \\
\hline 1,5 & 41,31 \\
\hline 2,0 & 12,07 \\
\hline 2,5 & 23,77 \\
\hline 3,0 & 31,57 \\
\hline 5,0 & 56,91 \\
\hline 10,0 & 15,00 \\
\hline 20,0 & 64,71 \\
\hline
\end{tabular}

Dentre os métodos usuais para determinação de peróxido de hidrogênio figuram os espectrofotométricos; porém, no caso dos efluentes, não foi possivel sua utilização devido aos interferentes.

Desta forma, o método amperométrico para determinação de $\mathrm{H}_{2} \mathrm{O}_{2}$ em FIA, descrito no Capítulo V, apresentou seletividade e sensibilidade satisfatórias para a determinação de $\mathrm{H}_{2} \mathrm{O}_{2}$ em experimentos desenvolvidos 
pelo IPEN; além do que, possibilitou análises com uma freqüência analítica em torno de 60 determinações/hora.

Não foi detectada a presença de $\mathrm{H}_{2} \mathrm{O}_{2}$ nos efluentes industriais já irradiados com feixes de elétrons para promover a destruição de espécies orgânicas, que assim passaram a ser melhor tolerados pelos microcrustáceos (Daphnia similis claus) nos testes de toxicidade. Já nas águas de cultivo (não poluídas), após irradiação foram encontradas concentrações expressivas de $\mathrm{H}_{2} \mathrm{O}_{2}$, tornando-as mortais aos microcrustáceos. 


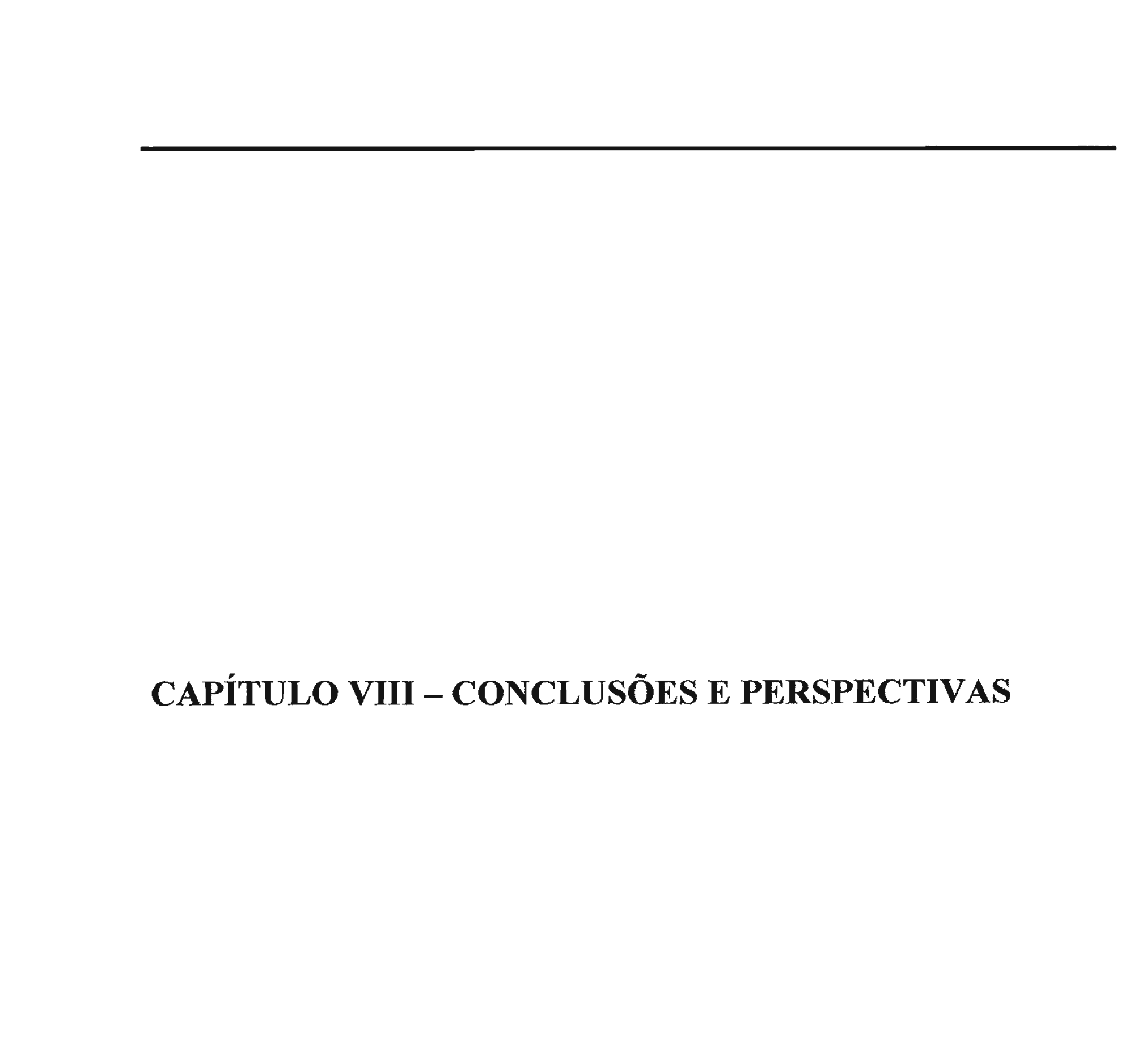




\subsection{ANÁliSE DE $\mathrm{CH}_{2} \mathrm{O}$ E DOS ÁCIDOS FÓRMICO $\mathrm{E}$ ACÉTICO NA FASE GASOSA MEDIANTE COLETA POR DIFUSÃO E DETERMINAÇÃO ELETROFORÉTICA}

A técnica de eletroforese capilar apresentou rapidez, simplicidade $\mathrm{e}$ versatilidade nas análises, consumindo pequena quantidade de amostra e reagentes, sendo de baixo custo operacional.

$\mathrm{O}$ limite de detecção alcançado foi de $1,0 \mu \mathrm{mol} \mathrm{L}^{-1}$, após préconcentração, correspondendo aproximadamente a $10 \mathrm{pmol} \mathrm{L}^{-1}$ na atmosfera.

O sistema de coleta por difusão é de fácil confecção, possibilitando o uso de água deionizada como substãncia coletora para espécies com alta constante de Henry e baixo fluxo de ar, sendo versátil para trabalhos em campo e não necessitando de processos de extração (agitadores mecânicos ou ultra-som), evitando a formação de artefatos no processo.

Como aperfeiçoamento futuro, pode-se pensar no interfaceamento direto entre o dispositivo de coleta e o equipamento de eletroforese, o que seria ideal para monitoramentos contínuos e prolongados. Essa tarefa será facilitada com a disseminação dos sistemas miniaturizados de eletroforese, para os quais também as fontes de alta tensão podem ser mais compactas.

\subsection{DETERMINAÇÃO DE $\mathrm{NH}_{3}$ NA FASE GASOSA DA ATMOSFREA MEDIANTE COLETA POR DIFUSÃO E DETERMINAÇÃO ELETROFORÉTICA}

As concentrações de amônia na fase gasosa variaram de $2,4 \mathrm{a} 17 \mu \mathrm{g} \mathrm{m}^{-3}$, valores que estariam um pouco acima do background de amônia conhecido na 
literatura (1 a $10 \mu \mathrm{g} \mathrm{m}^{-3}$ ), possivelmente por se tratar de um sítio de amostragem em zona urbana com alto índice de poluição.

A metodologia descrita revelou-se apropriada para a coleta de baixas concentrações de $\mathrm{NH}_{3}$ como as encontradas na atmosfera e para a sua determinação sensível e seletiva. Potencialmente, aplicações "indoor" também devem ser viáveis.

O limite de detecção (3S/R) foi ao redor $0,6 \mu \mathrm{mol} \mathrm{L}^{-1}(11 \mathrm{ppb})$, correspondendo aproximadamente a $0,3 \mu \mathrm{g} \mathrm{m}^{-3}$ de amônia na atmosfera. A rapidez, seletividade e facilidade de realização das análises de $\mathrm{NH}_{3}$ e as elevadas concentrações encontradas podem ensejar estudos futuros mais detalhados.

\subsection{ANÁlise DE $\mathrm{H}_{2} \mathrm{O}_{2}$ NA ATMOSFERA ATRAVÉS DE COLETA POR DIFUSÃ̃O E CRIOGÊNICA SEGUIDA DE DETERMINAÇÃO AMPEROMÉTRICA EM FLUXO}

O sistema FIA desenvolvido utilizando célula eletroquímica com mostrou-se eficaz para amostras ambientais de $\mathrm{H}_{2} \mathrm{O}_{2}$ nas fases gasosa e líquida da atmosfera, alcançando o limite de detecção de $0,1 \mu \mathrm{mol} \mathrm{L} \mathrm{L}^{-1}$, após pré-concentração

O crioamostrador passivo desenvolvido mostrou-se de fácil manejo, baixo custo e apropriado para coletas em campo, por não depender de energia elétrica (requerendo, contudo, um estoque de gelo seco).

A coleta de $\mathrm{H}_{2} \mathrm{O}_{2}$ por difusão através de tubos capilares ocos de polipropileno $\left(\mathrm{Oxyphan}^{(\mathbb{B})}\right.$ ) permite a injeção periódica de amostras sem que haja necessidade de manipulação, possibilitando a automação do sistema. 
As concentrações das amostras de $\mathrm{H}_{2} \mathrm{O}_{2}$ na atmosfera coletadas por crioamostragem e difusão variaram entre 10 e $60 \mathrm{pmol} \mathrm{L}^{-1}$.

\subsection{DETERMINAÇÃO DOS ÍONS MAJORITÁRIOS EM ÁGUA DE CHUVA POR ELETROFORES CAPILAR}

A metodologia desenvolvida mostrou-se adequada tanto para a determinação dos cátions $\mathrm{NH}_{4}^{+}, \mathrm{K}^{+}, \mathrm{Na}^{+}, \mathrm{Ca}^{2+}$ e para a dos ânions inorgânicos $\mathrm{Cl}^{-}, \mathrm{NO}_{3}{ }^{-}$e $\mathrm{SO}_{4}{ }^{2-}$.

O limite de deteç̧ão foi apropriado para as análises ambientais, com exceção, talvez, de regiões remotas e extremamente limpas. Nestes casos, em pesquisas futuras, haveria necessidade de buscar redução adicional nos limites de detecção para que possa deslocar a cromatografia de íons com as suas qualidades de maior rapidez e simplicidade, menor consumo de amostra, menor custo de equipamento, maior portabilidade.

\subsection{DETERMINAÇÃO DE ESPÉCIES DE S(IV) POR AMPEROMETRIA EM FLUXO EM AMOSTRAS DE VINHO}

O método desenvolvido mostrou-se rápido, sensível e simples para a determinação de $\mathrm{HSO}_{3}^{-}$livre e adutado e de $\mathrm{SO}_{2}$ em amostras de vinho, evitando as inconvenientes etapas de destilação e titulação do método padrão e não necessitando de "limpeza" dos eletrodos, uma vez que a cada troca de 
gota de mercúrio para uma nova injeção de amostra, obtem-se um novo eletrodo.

Também, as determinações das espécies de S(IV) podem ser feitas sem o auxílio da GDU, sendo que outros métodos em fluxo necessitam deste componente, sejam eles espectrofotométricos ou amperométricos com eletrodos sólidos ou modificados.

A freqüência analítica ficou em torno de 60 determinações/hora para uma faixa linear de $0,1 \mu \mathrm{mol} \mathrm{L} \mathrm{L}^{-1}$ a $1 \mathrm{mmol} \mathrm{L}^{-1}$ e o limite de detecção foi estimado em $0,1 \mu \mathrm{mol} \mathrm{L}{ }^{-1}$.

\subsection{DETERMINAÇÃO DE $\mathrm{H}_{2} \mathrm{O}_{2}$ POR AMPEROMETRIA EM FLUXO COM EM EFLUENTES E ÁGUA DE CULTIVO DE Daphnia similis APÓS SEREM IRRADIADOS COM FEIXES DE ELÉTRONS}

$\mathrm{O}$ método amperométrico para determinação de $\mathrm{H}_{2} \mathrm{O}_{2}$ em FIA descrito apresentou seletividade e sensibilidade satisfatórias para a determinação de $\mathrm{H}_{2} \mathrm{O}_{2}$ em experimentos desenvolvidos pelo IPEN.

Não foi detectada a presença de $\mathrm{H}_{2} \mathrm{O}_{2}$ nos efluentes industriais já irradiados com feixes de elétrons para promover a destruição de espécies orgânicas e bem tolerados pelos microcrustáceos (Daphnia similis claus) nos testes de toxicidade. Já nas águas de cultivo (não poluídas), mortais aos microcrustáceos após irradiação, concentrações expressivas de $\mathrm{H}_{2} \mathrm{O}_{2}$ foram encontradas. 


\section{REFERÊNCIAS BIBLIOGRÁFICAS}


1. ABNT Água - Ensaio de toxicidade aguda com Daphnia similis claus, NBR 12713, 1993.

2. Aero Laser GmbH, http://www.aero-laser.de/produk3.html, 2002.

3. Albuquerque, Y.D.T. "Nova Metodologia para Determinação Amperométrica Sequencial por Injeção em Fluxo Contínuo de $\mathrm{H}_{2} \mathrm{O}_{2}$, $\mathrm{HSO}_{3}^{-}$e Hidroxialcanosulfonato em Amostras Ambientais". Tese de Doutoramento, IQ-USP, 1993.

4. Allen, A.G.; Harrison, R.M.; Atmos. Environ., 1989, 23, 1591.

5. Altshuller, A. P.; Atmos. Environ, 1993, 27A, 21.

6. Altshuller, A.P., Miller, J.D., Sleva, S.F.; Anal. Chem., 1961, 33, 802.

7. AmbienteSP c Poluição causa doenças e mata, http://www.ambientesp.com.br (2002)

8. AmbienteSP a

http://www.ambientesp.com.br/materia.asp?Materia_ID=71 (2002)

9. AmbienteSP b Capital exporta poluentes para refúgios verdes, http://www.ambientesp.com.br/materia.asp?Materia_ $D=56$ (2002)

10. Andersen, H. V.; Hovmand, M. F.; Hummelshoj, P.; Jensen, N. O.; Atmos. Environ., 1999, 33, 1367.

11.Anderson, L. G., Lanning, J.A., Barrell, R., Miyagishima, J., Jones, R.H., Wolfe, P.; Atmos. Environ., 1996, 30, 12, 2113. 
12.Andrade, J.B., Pinheiro, H.L.C., Andrade, M.; J. Braz. Chem. Soc., $1995,6,287$.

13.Aneja, V.P., Chauhan, J.P.,. Walker, J.T; J. Geophys. Res., 2000, 105, 11535 .

14.Aneja, V.P., Stahel, E.P., Rogers, H.H., Witherpoon, A.M., Heck, V.W.; Anal. Chem., 1978, 50, 1705.

15. Araújo, A.N., Couto, C.M.C., Lima, J.L.F.C., Montenegro, M.C.B.S.; J. Agric. Food Chem., 1998, 46, 172.

16.Arents, R. R., Tejada, S.B.; Environ. Sci. Technol. 1989, 23, 1428.

17.Asman W.A.H.; Atmos. Environ., 1988, 22, 725.

18.Asman, W.A.H., Janssen, A.J.; Atmos. Environ., 1987, 21, 2099.

19.Atkins, P., Jones, L.; Chemistry, Molecules, Matter, and Changes, W.H. Freeman and Company, EUA, 1997.

20.Atkinson, R.; Atmos. Environ, 2000, 34, 2063-2101.

21. Azevedo, C.M.N., Araki, K., Toma, H.E., Angnes, L.; Anal. Chim. Acta, 1999, 387, 175.

22.Bächmann, K., Blaskowitz, K.K., Buratsch, H., Pohl, S., Sprenger, U.; J. Chromatogr., 1989, 382, 307.

23.Bächmann, K., Tenberken, B.; J. Chromatogr., 1996, 755, 121.

24.Bächmann, K., Tenberken, B.; J. Chromatogr., 1997, 775, 372.

25.Baird, N.C.; J. Chem. Educ., 1995, 72, 153. 
26.Baker M.B., Caniparoli D., Harrison H.; Atmos. Environ., 1981, 15, 43.

27.Barrie L.A., Fisher D., Koerner R.M.; Atmos. Environ., 1985, 19, 2055.

28.Barrie L.A., Hales J.M.; Tellus, 1984, 36B, 333.

29. Beilke, S., Gravenhorst, G.; Atmos. Environ., 1978, 12, 231.

30.Bergmeyer, H.U., Methods of Enzymatic Analysis, $2^{\text {nd }}$ Edition, Academic Press, New York, 1974.

31.Borrely, S. I., "Uso do Acelerador de Elétrons no Tratamento de Efluentes - Validação do Método pela Aplicação de Testes de Toxicidade Aguda" Tese de Doutoramento USP IPEN - 2001.

32. Briblecombe, P. The big smoke: A history of ar pollution in London since medieval times., Methuen, London, 1987.

33.Briblecombe, P., Stedman, D.H.; Nature, 1982, 298, 460.

34.Brocco, D., Tappa, R.; J. Chromatogr., 1986, 367, 240.

35.Brown, D.S., Jenke, D.R.; Analyst., 1987, 112, 899.

36.Buijsman, E., Maas, H.F.M., Asman, W.A.H.; Atmos. Environ., 1987, 21, 1009.

37. Calvert J.G., Su, F., Bottenheim J.W., Strausz, O .P.; Atmos. Environ., $1978,12,197$.

38.Calvert, J.G., Stockwell, W.R.; Environ. Sci. Technol., 1983, 17, 428.

39.Campos, T.L., Kok, G.L.; Atmos. Environ., 1996, 30, 2575. 
40.Campos, V.P., Costa A.C.A., Tavares, T.M., Quím. Nova, 1998, 21 , 418.

41.Cardoso, A ., Pitombo, L.R.M.; Quim. Nova, 1992, 15, 219.

42. Cardoso, M. F. "Produção e Transporte de Ozônio Troposférico em Cubatão, São Paulo". Dissertação de Mestrado, IAG-USP, 1997.

43.Carlier, P., Hannachi, H., Mouvier, G.; Atmos. Environ., 1986, 20, 11 , 2079 .

44.CETESB Operação Inverno no Estado de São Paulo, São Paulo, 2002.

45.CETESB Operação Rodízio, São Paulo, 1997.

46. CETESB Relatório de Qualidade do Ar no Estado de São Paulo, São Paulo (1994).

47.CETESB Relatório de Qualidade do Ar no Estado de São Paulo, São Paulo, 1995.

48.CETESB Relatório de Qualidade do Ar no Estado de São Paulo, São Paulo, 1996.

49.CETESB Relatório de Qualidade do Ar no Estado de São Paulo, São Paulo, 2001.

50.Chao-Jung, C., Charles, M.J., Sexton, K., Jeffries, H.E.; Environ. Sci. Technol, 1998, 32, 299.

51.Charlson R.J., Rhode, H.; Nature, 1982, 295, 683.

52.Charlson, R.J., Vong, R., Hegg, D.A.; J. Geophys. Res., 1983, 88, 1375. 
53. Chebbi, A., Carlier, P.; Atmos. Environ., 1996, 30, 4233.

54. Christensen, C.S., Skov, H., Nielsen, T., Lohse, C.; Atmos. Environ., $2000,34,287$.

55. Coker, L.E.; J. Assoc. Anal. Chem., 1986, 69, 8.

56. Conceição, G. M. S., Miraglia, S. G. E. K., Kisi, H. S., Saldiva, P. H. N., Singer, J. M. Air Pollution and Child Mortality: A Time-Series Study in São Paulo, Brazil.. Environmental Health Perspectives. , v.109, n.3, p.347 - 350, 2001.

57.Cowling, E.B.; Environ. Sci. Technol., 1982, 16, 110A.

58. Cramer, C. "Amperometrishe Detektion von $\mathrm{H}_{2} \mathrm{O}_{2}, \mathrm{H}_{3} \mathrm{COHOOH}$ und $\mathrm{H}_{3} \mathrm{COOCH}_{3} \mathrm{OH}$ nebeneinander in wassrigen Losungen". Tese de Doutoramento, Universitat Dortmund, 1995.

59. Dabek-Zlotorzynska E, McGrath M; J. Anal. Chem., 2000, 367, 507.

60.Dasgupta, P.K., DeCesare, K., Ullrey, J.C.; Anal. Chem., 1980, 52, 1912.

61.Dasgupta, P.K., Dong, S., Hwang, H., Yang, H.C., Genfa, Z.; Atmos. Environ, 1988, 22, 949.

62.Dasgupta, P.K., Dong, S., Hwang, H.; Aerosol Sci. Technol., 1990, 12, 98.

63.Dasgupta, P.K., Hunng, H., Genfa, Z.; Anal. Chem., 1996, 68, 2062.

64.Deng, Y.; Water Res., 1998, 32, 2249. 
65.Derísio, J. C. Introdução ao controle de Poluição Ambiental, São Paulo (1992).

66.Dodge, M.C.; Atmos. Environ, 2000, 34, 2103.

67. Dollard, G.L., Sandalls, F.J., Derwent, R.G.; Environ. Pollunt., 1989, 58,115 .

68.Dommen, J., Neftel, A., Sigg, A., Jacob, D.J.; J. Geophys. Res., 1995, $100,8953$.

69.Efron, B., Tibshirani, R.; Science, 1991, 253, 390.

70.EHC 54 Environmental Health Criteria Monographs http://www.inchem.org/pages/ehc.html, 1986.

71.EHC 89 Environmental Health Criteria Monographs http://www.inchem.org/pages/ehc.html, 1989.

72.Elbert, W., Breitenbach, S., Nefetel, A., Hahn, J.; J. Chromatogr., 1985, 328, 111.

73.EPA - United States Enviromental Protection Agency $h t t p: / / w w w . e p a . g o v(2003)$.

74.Fan, Q., Dasgupta, P.K.; Anal. Chem., 1994, 66, 551.

75.Ferm, M.; Atmos. Environ., 1979, 13, 1385.

76.Ferreira, C. de, Moreira-Nordermann, L.M.; Rev. Bras. Geof., 1984, 3, 9.

77.Finlayson-Pitts, B.J., Pitts, J.N.; Atmospheric Chemistry: Fundamentals and Experimental Techniques, Wiley, New York, 1986. 
78.Fogg, A.G., Fernández-Arciniega, M.A., Alonso, R.M.; Analyst., 1985, 110,851 .

79.Fornaro, A. "Chuva Ácida em São Paulo: Caracterização Química de Amostras Integradas e Sequenciais de Deposição Úmida". Dissertação de Mestrado, IQ-USP, 1991.

80.Fornaro, A., Gutz, I.G.R.; Atmos. Environ., 2003, 37, 117.

81.Fornaro, A., Isolani, P.C., Gutz, I.G.R.; Atmos. Environ., 1993, 27B, 307.

82.Forti, M.C. Moreira-Nordemann, L.M., Atmos. Environ., 1990, 24B, 335.

83.Forti, M.C., M.F.M., Moreira-Nordemann, L.M.; Rev. Bras. Geof., $1988,6,17$.

84.Fracassi da Silva, J.A.,do Lago, C.L.; Anal. Chem., 1998, 70, 4339.

85.Fracassi, J.A.S.; Quim. Nova, 2003, 26, 56.

86.Fried, A., Sewell, S., Henry, B., Wert, B.P., Gilpin, T., Drumond, J.R.; J. Geophys. Res., 1997, 102, 6253.

87.Fukushi, K., Takeda, S., Chayama, K., Wakida, S.I.; J. Chromatogr., $1999,834,349$.

88.Fung, Y.S., Lau, K.M.; Talanta, 1998, 45, 641.

89.Gaffney J.C., Streit G.E., Spall W.D.,Hall, J.H.; Environ. Sci. Technol. $1987,21,519$. 
90. Galloway, J.N., Likens, G.E., Keene, W.C., Miller, J.M.; J. Geophys. Res., 1982, 87, 8771.

91.Galvão, P. Chuva Ácida: Estudo de Caso no Campus USP/SP. Dissertação de Mestrado, Instituto de Geociências - USP, 1996.

92.Gatz, D.F.; Atmos. Environ, 1991, 25B, 1.

93. Gauri, K.L.; Holdren; Environ. Sci. Technol., 1983, 15, 383.

94. Graham \& Trotman, Acid Rain - A Review of the Phenomenon in the EEC and Europe, A report prepared for the Commission of the European Communities, directorate-General for Environment, Consumer Protection and Nuclear Sefety by Environmental Resources Limited, Graham \& Trotmen Limited, London SW1V DEm UK, 1983.

95. Granados, M., Maspoch, S., Blanco, M.; Anal. Chim. Acta., 1986, 179,445 .

96. Granat, L.; Tellus, 1972, XXIV, 6

97. Grönberg, L., Shen, Y., Jönsson, J.A.; J. Chromatogr. A, 1993, 655, 207.

98. Grosjean, D., Miguel, A.H., Tavares, T. M.; Atmos. Environ., 1990, 24B, 101 .

99.Grosjean, D., Tuazon, E.C., Fujita, E.; Environ. Sci. Technol., 1990, 24, 144.

100. Guiang, S.F., Krupa, S.V., Pratt, G.C.; Atmos. Environ., 1984, 18, 1677. 
101. Gunz, D.W., Hoffmann, M.R.; Atmos. Environ., 1990, 24A, 1601.

102. Gutz, I.G.R., Klockow, D.; Fres. Z. Anal. Chem., 1989, 335, 919.

103. Gutz, I.G.R.; Isolani, P.C.I. e Segundo, S.A., Quím. Nova, 1989, 12, 179.

104. Haag, H.P., Chuvas Ácidas, Fundação Cargill, Campinas, 77p; 1985

105. Haagen-Smit, A. J.; Ind. Eng. Chem., 1952, 44, 1342.

106. Haber, C., VanSaun, R.J., Jones, W.R.; Anal. Chem., 1998, 70, 2261.

107. Heikes, B.G., Welega, J.G., Kok, G.L., Lind, J.A., Lazrus, A.L.; Global Biogeochemical Cycles, 1988, $2,57$.

108. Heikes, B.G.; Atmos. Environ., 1984, 18, 1433.

109. Heikes, B.G.; J. Geophys. Res., 1992, 97, 18001.

110. Heikes, B.G.; J. Geophys. Res., 1996, 101, 14741.

111. Hellpointner, E., Gäb, S.; Nature, 1989, 337, 631.

112. Herlihy, L.J., Galloway, J.N., Mills, A.L.; Atmos. Environ., 1987, 21, 2397.

113. Hewitt, C.N., Kok, G.L.; J. Atmos. Chem., 1991, 12, 181.

114. Heyrovsky, J., Kuta, J.; Priciples of Polarography, Academic Press, New York 1996.

115. Horibe, Y., Shigoharam, K., Takakuwa, Y.; J. Geophys. Res., 1973, $78,2625$. 
116. Jackson, A.V.; Crit. Rev. Environ. Sci. Technol., 1999, 29, 175.

117. Jackson, P.E.; J. Chromatogr., 1995, 693, 155.

118. Jacob P., Tavares T. M. e Klockow D.; Fres. Z. Anal. Chem., 1986, 325,359 .

119. Jacob, P., Klockow, D.; J. Atmos. Chem., 1992, 15, 353.

120. Jacob, P., Tavares, T.M., Rocha, V.C., Klockow, D.; Atmos. Environ., 1990, 24A, 377.

121. Jianzhen, Y.; Environ. Sci. Technol., 1995, 29, 1923.

122. Kaniansky, D., Masár, M., Marák, J., Bodor, R.; J. Chromatogr., $1999,834,133$.

123. Kawamura, K., Ng, L., Kaplan, L.R.; Environ. Sci. Technol., 1985, 19, 1082.

124. Keene, W. C., Galloway, J.N.; Atmos. Environ., 1984, 18, 2491.

125. Keene, W.C., Pszenny, A.A.P., Galloway, J.N., Hawley, M.E.; $J$. Geophys. Res., 1986, 91, 6647.

126. Keene, W.C., Talbolt, R.W., Andrea, M.O., Beecher, K., Berresheim, H., Castro, M., Farmer, C.J., Galloway, J.N., Hoffaman, M.R., Li, S., Maben, R.J., Munger, W.J., Norton, R.B., Pszenny, A.P.A., Puxbaum, H., Westberg, H., Winiwater, W.; J. Geophys. Res., 1989, 94, 6457.

127. Keuken, M.P.; The Determination of Acid-Deposition-Related Compounds in the Lower Atmosphere, Tese de Doutoramento, Univ. de Amesterdam, 1989. 
128. Kiba, N., Sun, L., yokose, S., Kasue, M.T., Suzuki, T.T..; Anal. Chem. Acta, 1999, 378, 169.

129. Kieber, R. J., Rhines, M.F., Willey, J.D., Avery, G.B.; Atmos. Environ., 1999, 33, 3659.

130. Kieber, R. J.; et al.; Atmos. Environ. Sci. Technol., 1990, 24, 1477.

131. Klenidienst, T.E.; Atmos. Environ, 1988, 22, 1931.

132. Klockow, D., Jablonski, B., Niesser, R.; Atmos. Environ., 1979, 13, 1665 .

133. Klockow, D., Targa, H.J., Vautz, W.; Air Pollution and Vegetation Damage in the Tropics - the Serra do Mar as an Example, GKSS, Germany, 1997.

134. Kok, G.L., Heikes, B.G., Lind, J.A., Lazrus, A.L.; Atmos. Environ., $1990,24,283$.

135. Kok, G.L., Holler, T.P., Lopez, M.B., Nachtrieb, H.A., Yuan, M.; Environ. Sci. Technol., 1978, 12, 1072.

136. Komazaki, Y., Hiratsuka, M., Narita, Y., Tanaka, S., Fujita, T.; Fres. J. Anal. Chem., 1999, 363:(7), 686.

137. Kowalok, M. E.; Enviromental, July - August - 1993 v35 n6 p12 (13).

138. Krivácsy, Z., Molnár, A., Tarjányi, E., Glencsér, A., Kiss, G., Hlavay, J.; J. Chromatogr., 1997, A781, 223.

139. Lacaux, J.P., Delmas, R., Kouadio, G., Cros, B., Andreae, M.O.; $J$. Geophys. Res., 1992, 97(D6), 6195. 
140. Lara, L.B.L.S., Artaxo, P., Martinelli, L.A., Victoria, R.L., Camargo, P.B., Krusche, A., Ayers, G.P., Ferraz, E.S.N., Ballester, M.V.; Atmos. Environ., 2001, 35, 4937.

141. Larsen,.; Atmos. Environ, 1998, 32, 1485.

142. Lawson, D.R., Biermann, H.W., Tuazon, E.C., Winer, A.M., Mackay, G.I., Schiff, H.I., Kok, G.L., Dasgupta, P.K., Fung, K.; Aerosol Sci. Technol., 1990, 12, 64.

143. Lazrus, A.L., Kok, G.L., Lind, J.A., Gitlin, S.N., Heikes, B.G., Shetter, R.E.; Anal. Chem., 1986, 58, 594.

144. Lee, J.H., Lehy, D.F., Tang, L.N., Newman, L.; J. Geophys. Res., $1993,98,2911$.

145. Lee, J.H., Tang, I.N., Weinstein-Lyoyd, J.B.; Anal. Chem., 1990, 62, 2381.

146. Lee, M., Heikes, B.G., O Sullivan, D. W.; Atmos. Enmviron., 2000, 34, 3475 .

147. Lee, M., O'Sullivan, D., Noone, K.B., Heikes, B.G.; J. Atmos. Oceanic Technol., 1995, 12, 1060.

148. Levine, J. S. The Photochemistry of Atmospheres, Academic Press, 1985.

149. Levine, S.Z. and Schwartz, S.E.; Atmos. Enmviron. 1982, 16, 1725.

150. Levy, H; Science, 1971, 173, 141.

151. Likens G.E., Bormann F.H.; Science 1974, 184, 1176. 
152. Linares, P., Luque de Castro, M.D., Valcárcel, M.; Anal. Chim. Acta., $1989,225,443$.

153. Lind, J.A., Lazrus, A.L., Kok, G.L.; J. Geophys. Res., 1987, 92, 4171.

154. Liyuan, B., Dasgupta, P.K.; Anal. Chem., 1992, 64, 991.

155. Lopez, B., Masclet, P., Person, A., Degobert, P.; Poll. Atmos., 1987, 29, 113 .

156. Losno, R., Bergametti, G., Carlie, P., Mouvier, G.; Atmos. Environ, 1991, 25A, 763.

157. Lund, L., Federspiel, W., Hattler, B., University of Toledo, 2002, Evaluation of Hollow Fiber Membrane Permeability for Chronic Blood Oxygenation Devices, http://www.che.utoledo.edu/nams98/scripts/viewpap.cfm?ID=223

158. M., Pszenny, A., Suhre, K.; J. Geophys. Res., 1997, 102, 6003.

159. Mackay, G.I., Karecki, D.R., Schiff, H.I.; J. Geophys. Res., 1996, $101,14721$.

160. Mage, D., Ozolins, G., Peterson, P., Webster, A., Orthofer, R., Vandeweerd, V., Gwynne, M.; Atmos. Environ, 1996, 30, 681.

161. Manahan, S. E., Environ. Chem.. Lewis, NY, 1978, 7, 388.

162. Marshall, G.B, Midgley, D.; Analyst., 1983, 108, 701.

163. Martin, D., Tsivou, M., Bonsang, B., Abonnel, C., Carsey, T., Springer-Young, M., Pszenny, A., Suhre, K.; J. Geophys. Res., 1997, $102,6003$. 
164. Martins, A. P. - Um estudo sobre chuva ácida - IX Anais Encontro Nacional de Química Analítica - São Carlos - USP - 1996.

165. Massambani, O., Andrade, M.F.; Atmos. Environ., 1994, 28, 3165.

166. Matos, R.C., Pedrotti, J.J., Angnes, L.; Anal. Chim. Acta, 2001, 441, 73.

167. Matsumoto, K., Matsubara, H., Ukeda, H.; Agric. Biol. Chem., 1989, $\mathbf{5 3}, 2353$.

168. Mello,W.Z.; Environ. Poll., 2001, 114, 235.

169. MEMBRANA, 1990 http://www.membrana.com/about/history4.htm.

170. Meyer, J., Karst, U.; Anal. Chim. Acta, 1999, 401, 191.

171. Miguel, A.H., Aquino, F.R., Cardoso, J., Vasconcellos, P. C., Pereira, A., Márquez, K.; Environ. Sci. Technol, 1995, 29, 338.

172. Mohnen, V.A.; Sci. Amer., 1988, 14, 259.

173. Morales, J.A., Medina, H.J., Nava, M.G., Velásques, H., Santana, M.; J. Chromtogr. A, 1994, 671, 193.

174. Moylan, J.G., Bowes, F.W., Pappin, W.J.; J. Assoc. Anal. Chem., $1986,69,11$.

175. NIOSH, National Institute for Occupation Safety and Health http://www.cdc.gov/niosh/nmam/nmampub.html

176. Normas de Qualidade para Alimentos, vol. 6, Instituto Adolfo Lutz, São Paulo, 1976. 
177. O Estado de São Paulo (1998). O fracasso da conferência de Buenos Aires. endereço eletrônico na Internet: http://www.estado.com.br/jornal/.

178. Oden S.; Swed. Nat. Sci. Res. Counsil. Ecol. Comm., 1968, Bull 1, 1.

179. Orsini, C.Q., Tabacniks, M.H., Artaxo, P., Andrade, M.F.B., Keer, A.S.; Atmos. Environ., 1986, 20, 2259.

180. OSHA, Occupation Safety \& Health Administration http://www.oshaslc.gov/dts/sltc/methods/toc.html

181. Ottar B.; Atmos. Environ., 1978, 12, 445.

182. Pacáková, V., Coulfal, P., Stulik, K.; J. Chromatogr., 1999, 834, 257.

183. Paiva, R.P., Pires, M.A.F., Munita, C.S., Andrade, M.F., Gonçalves, F.L.T., Massambani, O.; Fres. Environ. Bull., 1997, 6, 508.

184. Parrish, D.D., Fehsenfeld, F.C.; Atmos. Environ, 2000, 34, 19211957.

185. Pedrotti, J., Angnes, L., Gutz, I.G.R.; Anal. Chim. Acta, 1994, 298, 393.

186. Penket, S.A ., Jones, B.M.R., Brice, K.A., Eggleton, A .E.J.; Atmos. Environ., 1979, 13, 123.

187. Pereira, E.A., Tavares, M.F.M., Cardoso, A.A.; J. Aoac Intern., 1999, 82, 1562.

188. Pereira, L. A. A., Saldiva, P. H. N., Menezes, J. J. C., Conceição, G. M. S., Zanobett, A., Schwartz, J., Dockery, D. W.Health Effects of 
Air Pollution Exposure on Children and Adolescents in São Paulo Brazil.. Pediatric Pulmonary., v.31, p.106 - 113, 2001.

189. Perrino, C., Catrambone, M., Bucchianico, A. Di Menno Di, Allegrini, I.; Atmos. Environ., 2002, 36, 5385.

190. Perrino, C., Gherardi, M.; Atmos. Environ., 1999, 33, 4579.

191. Pires, M. e Carvalho, L. R. F.; Anal. Chim. Acta, 1998, 367, 223.

192. POA - I Encontro sobre Aplicações Ambientais de Processos Oxidativos Avançados. Livro de resumos - Águas de São Pedro-São Paulo, 2001.

193. Possanzini, M., Febo, A., Liberti, A.; Atmos. Environ., 1983, 17, 2605.

194. Puxbaum, H., Rosenberg, C.., Gregori, M., Lanzerstorfer, C., Ober, E., Winiwater, W.; Atmos. Environ., 1988, 22, 2841.

195. Rand, G.M. , Fundamentals of Aquatic Toxicology. Taylor \& Francis, 1995.

196. Reche, F., Garrigós, M.C., Sanches, A., Jiménez, A.; J.Chromatogr. $A, 2000,896,51$.

197. Rio+10 (2002) http://riomaisdez.org.br

198. Robarge, W.P., Walker, J.T., McCulloch, R.B., Murray G.; Atmos. Environ., 2002, 36, 1661.

199. Rocha, F.R. Desenvolvimento e Aplicação de Métodos Eletroanalíticos em Fluxo para a Determinação de Traços $\mathrm{H}_{2} \mathrm{O}_{2}$, 
$\mathrm{HSO}_{3}^{-}$e Hidroximetanosulfonato na Fase Líquida da Atmosfera. IQUSP, 1999.

200. Rocha, F.R., Fracassi, J.A.S., Lago, C.L., Fornaro, A., Gutz, I.G.R.; Atmos. Environ., 2003, 37, 105.

201. Rossby C.G., Egner H.; Tellus, 1955, 7, 118.

202. Sakugawa, H., Kaplan, I.R.; Atmos. Environ., 1987, 21, 1791.

203. Sakugawa, H., Kaplan, I.R.; J. Geophys. Res., 1989, 94, 12957.

204. Sakugawa, H.; Atmos. Environ., 1993, 27B, 203.

205. Sanusi, A., Wortham, H., Millet, M., Mirabel, P.; Atmos. Environ., $1996,30,59$.

206. Sauer, F.; Atmos. Environ., 1997, 31, 1173.

207. Schiff, H.I., Haslie, D.R., Mackay, G.I., Iguchi, T., Ridley, B.A; Environ. Sci. Technol., 1983, 17, 352.

208. Schlitt, H.; J. Chromatogr. A., 1997, 762, 187.

209. Schwartz, S.E.; Science 1989, 243, 753.

210. Schwarzenbach, R.P., Gschwend, P.M., Imboden, D.M.; Environ. Org. Chem., 1993, 490.

211. Segundo, S.M.A. "Desenvolvimento e Aplicação de Métodos para Coleta e Quantificação de Traços de Peróxido de Hidrogênio e Espécies de Enxofre (IV) de Relevância Ambiental e Tecnológica". Tese de Doutorado, IQ-USP, 1997. 
212. Sehmel, G.A.; Atmos. Environ., 1980, 14, 983.

213. Seinfield, J. H.; Atmos. Chem. and Physics of Air Poll., John Willey \& Sons, 1986.

214. Slemr, F., Harris, G.W., Mackay, G.I., Schiff, H.I.; J. Geophys. Res., 1986, 91, 5371.

215. Slemr, F., Tremmel, H.G.; J. Atmos. Chem., 1994, 19, 371.

216. Smith, R. A.; Air and Rain: The Beginings of a Chemical Climatology, Longmans. Green, London, 1872.

217. Sollinger, S., Levsen, K., Emmrich, M;; J. Chromatogr., 1992, 609, 297.

218. Souza, S. R. “Ácidos Carboxílicos na Atmosfera de São Paulo. Um Estudo Analítico e Ambiental". Tese de Doutoramento, IQ-USP, 1998

219. Souza, S.R., Carvalho, L.R.F.; Quím. Nova, 1997, $20,245$.

220. Souza, S.R., Tavares, M.F., Carvalho, L.R.F.; J. Chromatogr., 1998, 796, 335 .

221. Staffelbach, T., Neftel, A., Dasgupta, P.K.; Geoph. Res. Letters, 1995, 22, 2605.

222. Stalfelbach, T.A., Kok, G.I., Heikes, B.G., McKully, B., Mackay, G.I., Karecki, D.R., Schiff, H.I.; J. Geophys. Res., 1996, 101, 14729.

223. Stockwell W.R., Calvert J.G.; Atmos. Environ., 1983, 17, 2231 
224. Sullivan, J.J., Hollingworth, T.A., Wekell, M.M., Newton. R.T., Larose, J.E.; J. Assoc. Anal. Chem., 1986, 69, 542.

225. Sutton, M.A., Dragositis, U., Tang, Y.S., Fowler D.; Atmos. Environ., $2000,34,855$.

226. Suzuki, Y.; Anal. Chem. Acta, 1997, 353, 227.

227. Talbot, R. W., Andrea, M.O., Berresheim, H., Jacob, D.J., Beecher, K.M.; J. Geoph. Res, 1990, 95, 16799.

228. Tanimoto, Y.D., Gutz, I.G.R.; Resumo VI Encontro Nacacional Química Analítica, Araraquara, 1991, p.199.

229. Tanner, R.L., Shen, J.; Aerosol Sci. Technol., 1990, 12, 86.

230. Tanner, R.L., Markovits, G.Y., Ferreri, E.M., Kelly, T.J.; Anal. Chem., 1986, 58, 1857.

231. Tanner, R.L., Schorran, D.E.; Atmos. Environ., 1995, 29, 1113.

232. Tarnner, R.L., Markovits, G.Y., Ferreri, E.M., Kelly, T.J.; Anal. Chem., 1986, 58, 1857.

233. Tavares, M.F.M.; Quím. Nova, 1996, 19, 173.

234. Tavares, M.F.M.; Quim. Nova, 1997, $20,493$.

235. Thompson, A. M.; Tellus, 1980, 32, 376.

236. Uchiyama, S., Hasegawa, S.; Atmos. Environ., 1999, 33, 1999.

237. Ulrich, B.; Atmos. Environ., 1984, 18, 621.

238. Vairavamurthy, A; Atmos. Environ., 1992, 26A, 11, 1965. 
239. Valsecchi, S., Tartari, G., Polesello, S.; J. Chromatogr., 1997, 760, 326.

240. Van der Hoek, K.W.; Atmos. Environ., 1998, 32, 315.

241. Varnan, A.H., Sutherland, J.P., Bebidas Tecnologia Química y Microbiologia, 1994, Acribia S.A.

242. Vermeulen A.J.; Environ. Sci. Technol., 1978, 12, 1017.

243. Voldner, E.C., Barrie, L.R., Sirois, S.; Atmos. Environ., 1986, 20, 2101.

244. Weller, R., Schrems, O.; Geoph. Res. Letters, 1993, $20,125$.

245. Whitby, K.T.; Atmos. Environ., 1978, 12, 135.

246. Yamada, M., Nakada, T., Suzuki, S.; Anal. Chim. Acta., 1983, 147, 401.

247.Zemann, A.J., Schnell, E., Volgger, D., Bonn, G.K.; Anal. Chem., $1998,70,563$.

248. Zervas, E., Montagne, X., Lahaye, J.; Atmos. Environ., 1999, 33, 4953.

249. Zhang, J., He, Q., Lloy, P.J.; Environ. Sci. Technol., 1994, 28, 146.

250.Zhi, Z., Rios, A., Valcárcel, M.; Analyst., 1995, 120, 2013.

251. Zurek, G., Karst, U.; J. Chromatogr. A, 1999, 864, 191. 